

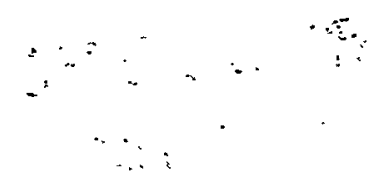

Issued by Sandia National Laboratories, operated for the United States Department of Energy by Sandia Corporation.

NOTICE: This report was prepared as an account of work sponsored by an agency of the United States Government. Neither the United States Government nor any agency thereof, nor any of their employees, nor any of their contractors, subcontractors, or their employees, makes any warranty, express or implied, or assumes any legal liability or responsibility for the accuracy, completeness, or usefulness of any information, apparatus, product, or process disclosed, or represents that its use would not infringe privately owned rights. Reference herein to any specific commercial product, process, or service by trade name, trademark, manufacturer, or otherwise, does not necessarily constitute or imply its endorsement, recommendation, or favoring by the United States Government, any agency thereof, or any of their contractors or subcontractors. The views and opinions expressed herein do not necessarily state or reflect those of the United States Government, any agency thereof, or any of their contractors.

Printed in the United States of America. This report has been reproduced directly from the best available copy.

Available to DOE and DOE contractors from Office of Scientific and Technical Information P.O. Box 62

Oak Ridge, TN 37831

Prices available from (615) 576-8401, FTS 626-8401

Available to the public from

National Technical Information Service

U.S. Department of Commerce

5285 Port Royal Rd

Springfield, VA 22161

NTIS price codes

Printed copy: A10

Microfiche copy: $\mathrm{AO1}$

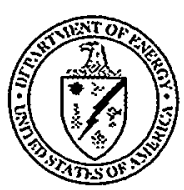




\section{DISCLAIMER}

Portions of this document may be illegible in electronic image products. Images are produced from the best available original document. 
SAND98-1833

Unlimited Release

Printed August 1998

\title{
1997 \\ Annual Site Environmental Report, Sandia National Laboratories, Albuquerque, New Mexico
}

\author{
Charles H. Fink, Editor \\ Environmental and Emergency Management Department \\ Sandia National Laboratories \\ P.O. Box 5800 \\ Albuquerque, NM 87185-0854 \\ Dianne Duncan, Editor \\ Environmental and Emergency Management Department \\ Technadyne, Inc. \\ 8500 Menaul, Suite A225 \\ Albuquerque, NM 87112 \\ Rebecca Sanchez, Associate Editor and Technical Word Processing \\ Environmental and Emergency Management Department \\ Jobs Plus \\ 1512-D Wyoming Blvd., NE \\ Albuquerque, NM 87112
}

\begin{abstract}
Sandia National Laboratories/New Mexico (SNL/NM) is operated in support of the U.S. Department of Energy (DOE) mission to provide weapon component technology and hardware for national security needs. SNL/NM also conducts fundamental research and development to advance technology in energy research, computer science, waste management, electronics, materials science, and transportation safety for hazardous and nuclear components. In support of SNL's mission, the Environment, Safety, and Health (ES\&H) Center and the Environmental Restoration (ER) Project at SNL/NM have established extensive environmental programs to assist SNL's line organizations in meeting all applicable local, state, and federal environmental regulations and DOE requirements. This annual report for calendar year 1997 (CY97) summarizes the compliance status of environmental regulations applicable to the site. Environmental program activities include terrestrial surveillance; ambient air and meteorological monitoring; hazardous, radioactive, and solid waste management; pollution prevention and waste minimization; Environmental Restoration (ER); oil and chemical spill prevention; and National Environmental Policy Act (NEPA) activities. This report has been prepared in compliance with DOE Order 5400.1, General Environmental Protection Program (DOE 1990a).
\end{abstract}




\section{Preface}

This report presents summary information on the compliance status and monitoring results for Sandia National Laboratories, New Mexico (SNL/NM). The reader may also refer to the Glossary at the end of the report for expansion on various subjects. An Annual Site Environmental Report (ASER) is also produced for the Kauai Test Facility (KTF) and is attached as Appendix B. A brief overview of the SNL/NM site and map location is available on the Internet at: http://www.sandia.gov/visit.htm Additional information can be found by entering search criteria at: http://www.sandia.gov.search.html 


\section{Contributors}

\begin{tabular}{|c|c|c|}
\hline Contributor & Section & $\underline{\text { Title }}$ \\
\hline \multirow[t]{5}{*}{ Joe Bonaguidi } & 2.1.7 & Clean Water Act (CWA) (Surface Discharges) \\
\hline & 2.2 & Summary of Environmental Permits (Surface Discharges) \\
\hline & 3.4 & Spill Prevention Plans for Oil and Chemical Storage and Use \\
\hline & 3.5 & Underground Storage Tank (UST) Management \\
\hline & 6.2 & Surface Discharge Program \\
\hline \multirow[t]{2}{*}{ Dave Castillo } & 2.1 .9 & Toxic Substances Control Act (TSCA) (PCBs) \\
\hline & 3.2 .6 & The Polychlorinated Biphenyls (PCB) Program \\
\hline Warren Cox & 3.1 & Environmental Restoration (ER) Project \\
\hline \multirow[t]{5}{*}{ Todd Culp } & 2.1 .6 & Clean Air Act (CAA) and CAA Amendments (CAAA) of 1990 \\
\hline & 2.6 & Summary of Reporting Requirements \\
\hline & 5.3 & $\begin{array}{l}\text { Radiological Air Emissions National Emissions Standards for } \\
\text { Hazardous Air Pollutants (NESHAP) Compliance }\end{array}$ \\
\hline & 5.4 & Assessment of Potential Dose to the Public \\
\hline & Apx B & Site Environmental Report for the Kauai Test Facility (KTF) \\
\hline \multirow[t]{5}{*}{ Mike du Mond } & 2.1 .6 & Clean Air Act (CAA) and CAA Amendments (CAAA) of 1990 \\
\hline & 2.2 & Summary of Environmental Permits (Air) \\
\hline & 2.3 & Current Compliance Issues and Actions (Air Quality) \\
\hline & 2.6 & Summary of Reporting Requirements \\
\hline & 5.5 & Air Quality Requirements and Compliance Strategies \\
\hline \multirow[t]{3}{*}{ Regina Deola } & 1.5 & Regional Climate \\
\hline & 5.1 & Meteorological Monitoring Program \\
\hline & 5.2 & Ambient Air Surveillance Program \\
\hline \multirow[t]{6}{*}{ Dianne Duncan } & $\mathrm{ES}$ & Executive Summary \\
\hline & 1.1 & Sandia National Laboratories Operational Areas \\
\hline & 1.2 & Site Setting and Demographics \\
\hline & 1.3 & Geology and Hydrology (Geology) \\
\hline & 1.4 & Ecological Setting \\
\hline & 2.1 .8 & Safe Drinking Water Act (SDWA) \\
\hline Stanley Edmund & 2.4 & 1997 Audits and Appraisals \\
\hline \multirow[t]{3}{*}{ Charles Fink } & 2.1 .7 & Clean Water Act (CWA) (Storm Water Runoff) \\
\hline & 2.2 & Summary of Environmental Permits (Storm Water) \\
\hline & 6.3 & Storm Water Program \\
\hline Dan Finnegan & 2.4 & 1997 Audits and Appraisals \\
\hline
\end{tabular}


Contributors (Continued)

\begin{tabular}{|c|c|c|}
\hline Contributor & Section & Title \\
\hline \multirow[t]{6}{*}{ Joan Harris } & 2.1 .5 & National Environmental Policy Act (NEPA) \\
\hline & 2.1.11 & Endangered Species Act (ESA) \\
\hline & 2.1.12 & Cultural Resources Acts \\
\hline & 2.1.13 & Executive Orders (EOs) \\
\hline & 3.6 & National Environmental Policy Act (NEPA) Compliance Activities \\
\hline & Apx B & Site Environmental Report for the Kauai Test Facility (KTF) \\
\hline Heidi Herrera & 4.0 & Terrestrial Surveillance Program \\
\hline \multirow[t]{2}{*}{ Jim Hylko } & 5.3 & $\begin{array}{l}\text { Radiological Air Emissions National Emissions Standards for } \\
\text { Hazardous Air Pollutants (NESHAP) Compliance }\end{array}$ \\
\hline & 5.4 & Assessment of Potential Dose to the Public \\
\hline Jeff Jarry & 3.2 .2 & Radioactive Waste Management \\
\hline \multirow[t]{3}{*}{ Adrian Jones } & 2.1.7 & Clean Water Act (CWA) (Wastewater) \\
\hline & 2.2 & Summary of Environmental Permits (Wastewater) \\
\hline & 6.1 & Wastewater Discharge Program \\
\hline Gabe King & 3.2 .4 & Solid Waste Management \\
\hline \multirow[t]{2}{*}{ Franz Lauffer } & 1.3 & Geology and Hydrology (Hydrology) \\
\hline & 7.0 & Groundwater Monitoring and Protection Programs \\
\hline Merri Lewis & 2.5 & 1997 Releases and Environmental Occurrences \\
\hline Al Lopez & Apx B & Site Environmental Report for the Kauai Test Facility (KTF) \\
\hline Kylene Molley & 3.3 & Waste Minimization and Pollution Prevention (P2) Programs \\
\hline \multirow[t]{4}{*}{ Darlene Moore } & 2.1 .4 & Federal Facility Compliance Act (FFCAct) \\
\hline & 2.2 & Summary of Environmental Permits (Hazardous Waste) \\
\hline & 2.3 & Current Compliance Issues and Actions (Mixed Waste) \\
\hline & 3.2 .3 & Mixed Waste (MW) Management \\
\hline Hans Oldewage & 4.0 & Terrestrial Surveillance Program \\
\hline \multirow[t]{2}{*}{ Phyllis Peterson } & 2.1 .4 & Federal Facility Compliance Act (FFCAct) \\
\hline & 3.2 .3 & Mixed Waste (MW) Management \\
\hline JoAnn Pigg & 2.1 .10 & Federal Insecticide, Fungicide, and Rodenticide Act (FIFRA) \\
\hline Stephanie Pope & 1.4 & Ecological Setting \\
\hline
\end{tabular}




\section{Contributors (Concluded)}

Contributor

Pam Puissant

Doug Salmi

Barry Schwartz

Brian Stone

Bill Suderman

Francine Vigil
Section

$\underline{T i t l e}$

8.0 Quality Assurance

8.0 Quality Assurance

8.0 Quality Assurance

2.1.1 Comprehensive Environmental Response, Compensation, and Liability Act (CERCLA)

2.1.2 Superfund Amendments and Reauthorization Act (SARA) Title III

2.1.9 Toxic Substances Control Act (TSCA) (Asbestos)

3.2.5 The Asbestos Program

2.1.3 Resource Conservation and Recovery Act (RCRA)

3.2.1 Hazardous Waste Management 


\section{ACKNOWLEDGMENTS}

The Annual Site Environmental Report (ASER) publishing staff wish to thank the participating individuals from the Environment, Safety, and Health Center (7500) and the Environmental Restoration (ER) Project (6000) who contributed their time, expertise, and data, as well as providing their untiring guidance in producing this report.

\section{NOTE TO THE READER}

If you have comments or questions about this report, or need further information, please contact:

William R. Keener

Sandia National Laboratories

ES\&H Center

Mail Stop (MS) 1054

P.O. Box 5800

Albuquerque, NM 87185

Office: (505) 844-1690

Fax: (505) 844-9968

E-mail: Internet://RWKeene@Sandia.gov 


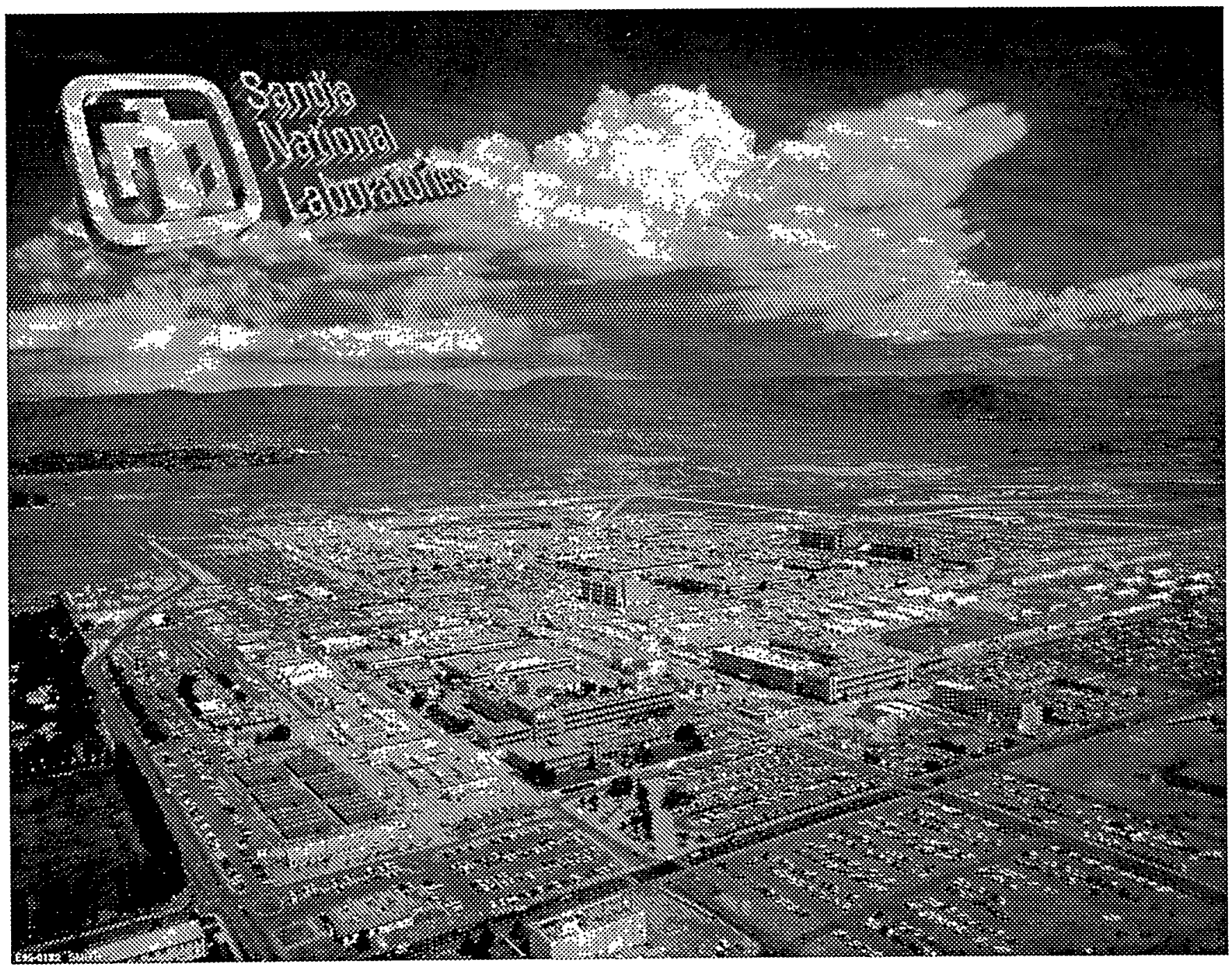

Aerial view of Sandia National Laboratories, Technical Area I looking southeast. The Sandia and Manzano Mountains are seen in the background. 


\title{
CONIENTS
}

\author{
ABSTRACT \\ CONTRIBUTORS \\ ABBREVIATIONS \\ EXECUTIVE SUMMARY
}

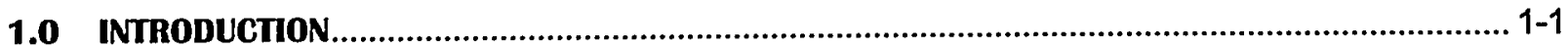

1.1 Sandia National Laboratories. Operational Areas ...................................................... 1-2

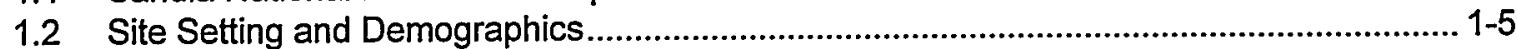

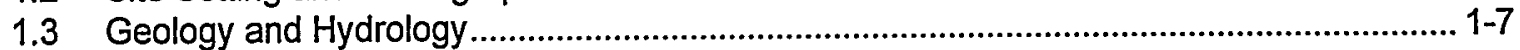

1.4 Ecological Setting............................................................................................... 1-12

1.5 Regional Climate ................................................................................................. 1-14

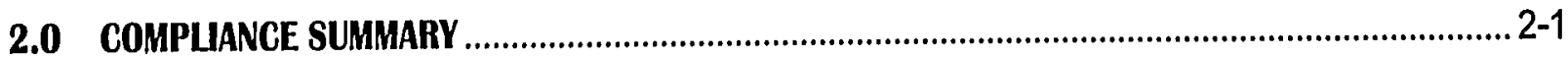

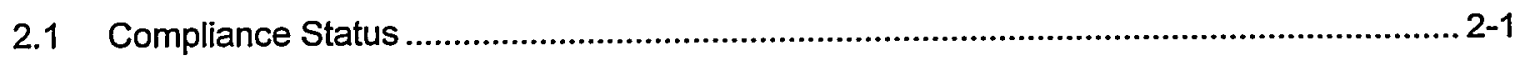

2.1.1 Comprehensive Environmental Response, Compensation, and Liability Act (CERCLA) .......................................................................................2 2-1

2.1.2 Superfund Amendments and Reauthorization Act (SARA) Title III ....................... 2-1

2.1.3 Resource Conservation and Recovery Act (RCRA) ............................................ 2-2

2.1.4 Federal Facility Compliance Act (FFCAct) ......................................................... 2-4

2.1.5 National Environmental Policy Act (NEPA) ............................................................. 2-4

2.1.6 Clean Air Act (CAA) and CAA Amendments (CAAA) of $1990 \ldots \ldots \ldots \ldots \ldots \ldots \ldots \ldots . . . . . .2-5$

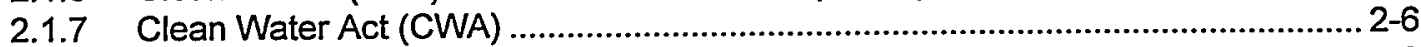

2.1.8 Safe Drinking Water Act (SDWA) .................................................................... 2-8

2.1.9 Toxic Substances Control Act (TSCA) .............................................................. 2-8

2.1.10 Federal Insecticide, Fungicide, and Rodenticide Act (FIFRA) ............................ 2-8

2.1.11 Endangered Species Act (ESA) .................................................................... 2-8

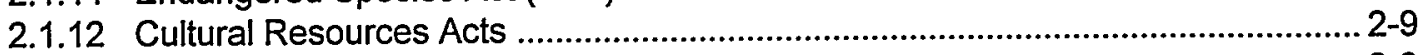

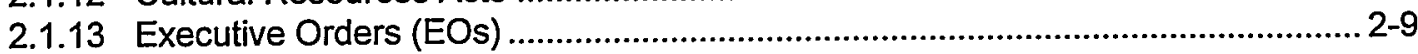

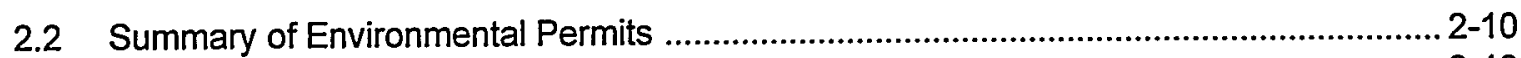

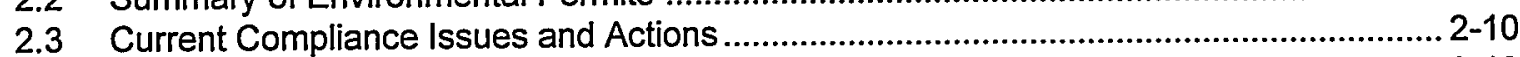

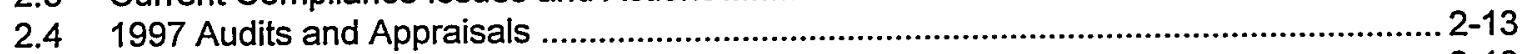

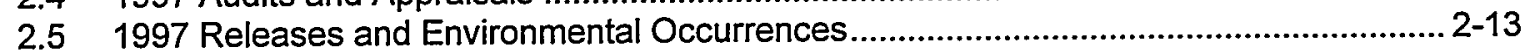

2.6 Summary of Reporting Requirements ..................................................................... 2-17

3.0 ENVIRONMENTAL PROGRAMS INFORMATION ............................................................... 3-1

3.1 Environmental Restoration (ER) Project .................................................................... 3-1

3.2 Waste Management Programs ................................................................................... $3-4$

3.2.1 Hazardous Waste Management............................................................................... 3-5

3.2.2 Radioactive Waste Management .................................................................... 3-6

3.2.3 Mixed Waste (MW) Management.................................................................... 3-8

3.2.4 Solid Waste Management ................................................................................. 3-11

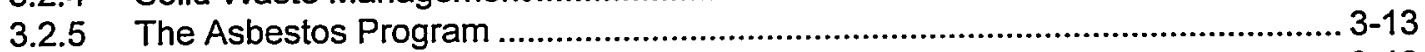

3.2.6 The Polychlorinated Biphenals (PCB) Program ............................................... 3-13 
ConTENTS (Continued)

3.3 Waste Minimization and Pollution Prevention (P2) Programs ...................................... 3-14

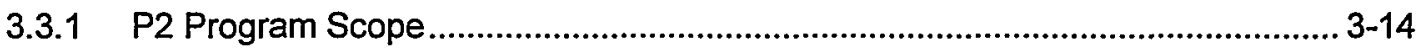

3.3.2 Generator Set Aside Fee (GSAF) Program ................................................... 3-14

3.3.3 Pollution Prevention Opportunity Assessments (PPOAs) .................................. 3-15

3.3.4 Return-on-Investment (ROI) Projects ................................................................ 3-16

3.3.5 Recycling and Waste Minimization ..................................................................... 3-16

3.4 Spill Prevention Plans for Oil and Chemical Storage and Use ..................................... 3-17

3.5 Underground Storage Tank (UST) Management ................................................... 3-19

3.6 National Environmental Policy Act (NEPA) Compliance Activities ............................... 3-20

4.0 TERRESTRIAL SURVEILIANCE PROGRAM ..............................................................................

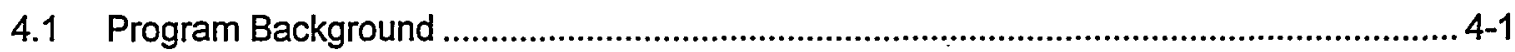

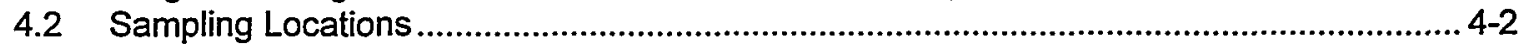

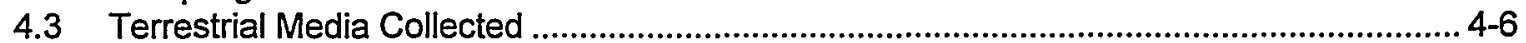

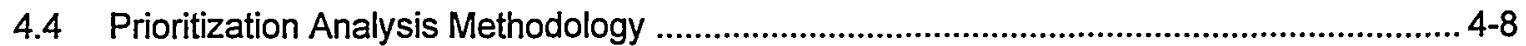

4.5 Terrestrial Surveillance Radiological Results ........................................................... 4-9

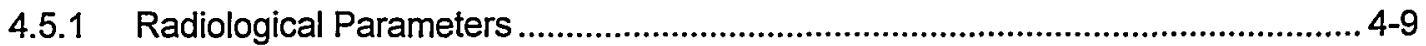

4.5.2 Onsite and Perimeter Radiological Results ............................................... 4-9

4.6 Terrestrial Surveillance Nonradiological Results ...................................................... 4-13

4.6.1 Nonradiological Parameters.............................................................................. 4-13

4.6.2 Onsite and Perimeter Nonradiological Results ............................................... 4-15

4.7 Non-Routine Surveillance Activities ...................................................................... 4-17

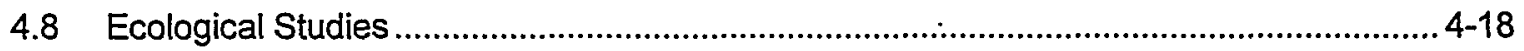

5.0 AIR QUALTY COMPUANCE AND METEOROLOGICAL MONITORING ......................................... 5-1

5.1 Meteorological Monitoring Program ......................................................................... 5-1

5.1.1 Meteorological Monitoring Results ................................................................... 5-2

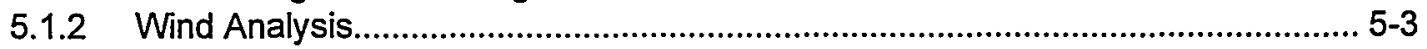

5.2 Ambient Air Surveillance Program ...................................................................... 5-6

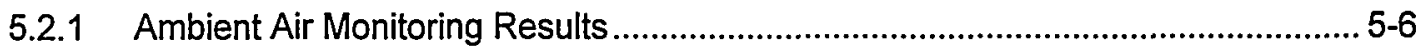

5.3 Radiological Air Emissions National Emission Standards for Hazardous

Air Pollutants (NESHAP) Compliance. 
CONTENTS (Continued)

5.4 Assessment of Potential Dose to the Public .................................................................... 5-18

5.4.1 NESHAP Dose Assessment Input .................................................................... 5-19

5.4.2 Dose Assessment Results .......................................................................... 5-22

5.5 Air Quality Requirements and Compliance Strategies ................................................. 5-23

5.5.1 New Program Directions Under CAAA Title $V$................................................... 5-23

5.5.2 New Air Compliance Activities in 1997 ............................................................. 5-26

5.5.3 Criteria Pollutants .......................................................................................... 5-26

5.5.4 Pollution Prevention in Permitting Pilot (P4) Project ........................................... 5-28

6.0 WASTEWATER, SURFACE DISCHARGE, AND STORM WATER PROGRAMS.................................... 6-1

6.1 Wastewater Discharge Program ................................................................................. 6-1

6.1.1 Wastewater Monitoring Stations ........................................................................... 6-2

6.1.2 Permitting and Reporting ....................................................................................6-3

6.1.3 TA-V Radiological Screening ..............................................................................6-4

6.1.4 Wastewater Sampling ..........................................................................................6-4

6.1.5 Summary of Monitoring Results .......................................................................... 6-5

6.2 Surface Discharge Program....................................................................................... 6-5

6.3 Storm Water Program ...............................................................................................6 6-7

6.3.1 Storm Water Program Activities ............................................................................6-8

6.3.2 NPDES Permit Application .................................................................................. 6-9

6.3.3 Storm Water Monitoring Stations ......................................................................... 6-10

6.3.4 Storm Water Monitoring Results ........................................................................... 6-10

7.0 GROUNDWATER MONITORING AND PROTECTION PROGRAMS ……...................................... 7-1

7.1 Groundwater Program Overview................................................................................... 7-1

7.2 Water Level Trends .................................................................................................

7.2.1 Water Level Trends in the Vicinity of TA-III...................................................... 7-6

7.2.2 Water Level Trends in the Vicinity of Sandia North .............................................. 7-7

7.2.3 Water Level Trends East of the Tijeras Fault Complex ......................................... 7-8

7.3 Potentiometric Surface ............................................................................................... 7-8

7.3.1 West of the Tijeras Fault Complex ......................................................................... 7-8

7.3.2 East of the Tijeras Fault Complex ....................................................................... 7-10

7.3.3 Shallow Water-Bearing Zones ............................................................................... $7-10$ 


\section{CONTENTS (Continued)}

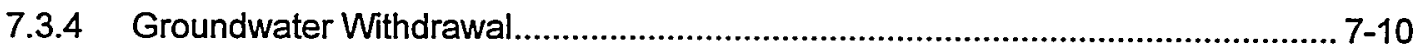

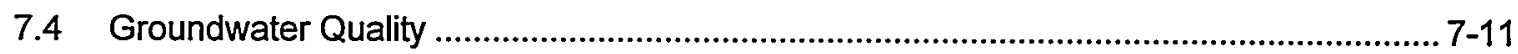

7.4.1 Groundwater Surveillance Task Water Quality Results ..................................... 7-12

7.4.2 ER Project Water Quality Results ............................................................ 7-14

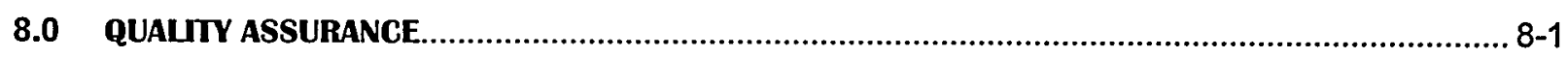

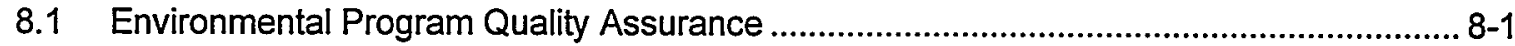

8.2 Environmental Sampling and Analysis .................................................................. 8-2

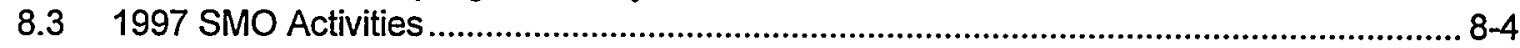

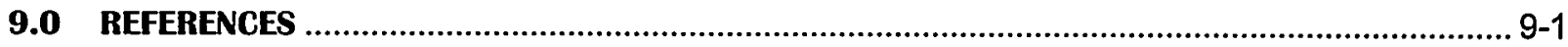

GLOSSARY

APPENDIX A Environmental Regulations and Standards ...................................................

APPENDIX B Site Environmental Report for the Kauai Test Facility (KTF) .................................B-1 


\section{Figures}

1-1 SNL/NM and the KAFB Site Showing Technical Areas I Through V, the U.S. Forest Service Land Withdrawal, and Various Remote Test Areas Used by SNL/NM............................ 1-3

1-2 A Micro-transmission Developed at the MDL ............................................................................. 1-4

1-3 Sandia's Phil Rodacy Demonstrates a Mock Chemical-Sensing Detector................................. 1-4

1-4 The Z-Facility, an Accelerator Used in Nuclear Fusion Research .......................................... 1-5

1-5 Albuquerque Site Regional Setting in the Vicinity of SNL/NM .................................................. 1-6

1-6 Albuquerque Basin, North Central New Mexico .................................................................... 1-8

1-7 Generalized Geology in the Vicinity of SNL/NM and KAFB .................................................... 1-10

1-8 Typical Vegetation Found in the Open Areas of KAFB West of the Land Withdrawal Boundary............................................................................................................ 1-13

1-9 Typical Vegetation Found in the Higher Elevations and Foothill Areas of KAFB East of the Land Withdrawal Boundary .................................................................................. 1-13

4-1 Onsite and Perimeter Sampling Locations ............................................................................. 4-3

4-2 Offsite Sampling Locations ........................................................................................................... 4-7

4-3 Onsite and Perimeter Sampling with Category 2 and Category 3 Designations ........................ 4-11

4-4 Sandia's Stephanie Pope Setting Up Line Transects for Small Mammal Capture

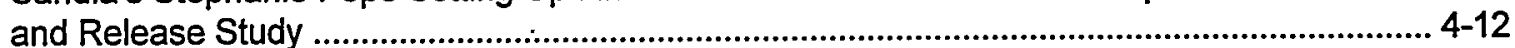

4-5 TLD Results Summarized Over the Past Six Years (1991-1997) ............................................ 4-14

5-1 The Meteorological Tower Network at the SNL/NM Site ............................................................. 5-2

5-2 1997 Annual Wind Roses for Towers CL1, A36, and SC1 ................................................... 5-5

5-3 1997 Annual Wind Roses for Daytime and Nighttime Wind Frequency at the A36 Tower ........... 5-7

5-4 Ambient Air Monitoring Equipment Located at Six Stations Throughout the SNL/NM Site .......... 5-8

5-5 Locations of the 15 NESHAP Facilities at SNL/NM that Reported Radionuclide Releases

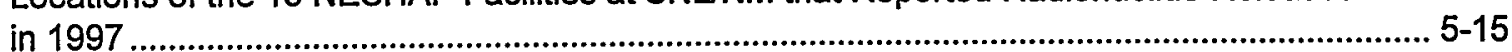

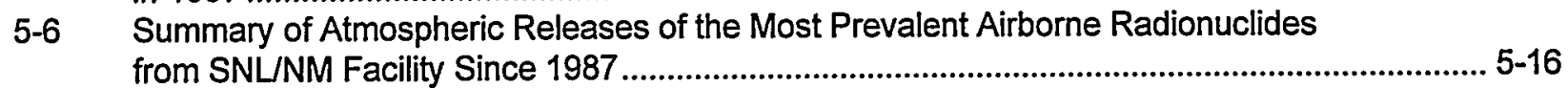

6-1 Wastewater Monitoring Station Locations at SNL/NM ...........................................................6.2

6-2 Storm Water Monitoring Stations Locations at SNL/NM......................................................... 6-8

7-1 Organizational Structure of Groundwater Monitoring Activities in 1997 .................................... 7-2

7-2 Location of Wells Used for Groundwater Level and Water Quality Monitoring in 1997................ 7-4

7-3 Areas (Shaded) on KAFB with Distinct Water Level Trends ..................................................... 7-6

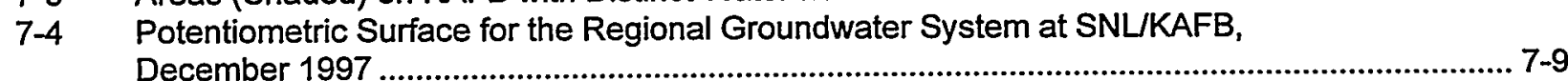




\section{TABLES}

1-1 Counties Within a 50-mile Radius of SNL/NM ...................................................................... 1-7

2-1 SNL/NM Reporting Activities in 1997 with Respect to SARA Title III Compliance ....................... 2-2

2-2 1997 Summary of SNL/NM's Chemical Purchases in Quantities Greater than 1,000 lb ............. 2-7

2-3 Summary of Environmental Permits and Registrations in Effect During 1997 ......................... 2-11

2-4 Audits and Appraisals Conducted by External Agencies in 1997 ............................................ 2-14

2-5 Summary of Environmental Occurrence Categories Over the Past Five Years........................ 2-15

3-1 Summary of ER Project Status Since the Program's Inception in 1992 .................................... 3-3

3-2 Important Documents for the ER Project............................................................................. 3-3

3-3 Five-year Summary of Waste Handling at the HWMF......................................................... 3-7

3-4 Breakdown of Hazardous Waste Handled by the HWMF in 1997 .............................................. 3-7

3-5 Five-Year Summary of Radioactive Waste Handled at SNL/NM ............................................. 3-9

3-6 Mixed Waste Treatment Categories and the Current Preferred Treatment Options ................... 3-10

3-7 SWTF Activity Summary for 1997. .................................................................................... 3-12

3-8 Detailed Breakdown of Recyclable Materials Received From All Agencies ............................. 3-12

3-9 Drivers for Pollution Prevention and Waste Minimization Programs .......................................... 3-15

3-10 Categories of Waste Recycled at SNL/NM in 1997 ....................................................... 3-17

3-11 Important Documents for Waste Management Programs ..................................................... 3-18

4-1 Onsite Terrestrial Surveillance Locations and Sample Types ....................................................4-4

4-2 Perimeter Terrestrial Surveillance Locations and Sample Types ........................................... 4-5

4-3 Offsite (Community) Terrestrial Surveillance Locations and Sample Types ............................... 4-6

4-4 Analysis Performed on Environmental Media Sample Types .................................................. 4-8

4-5 Decision Matrix for Determining Priority Action Levels Based on Categories

Assigned at Each Sampling Location .................................................................................. 4-9

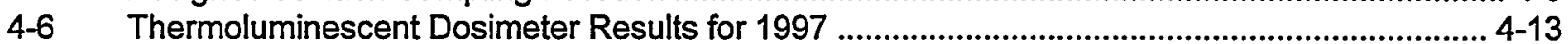

4-7 Important Documents for the Terrestrial Surveillance Program .................................................. 4-19

5-1 The 1997 Annual Climatic Summary from Tower A36 .............................................................. 5-3

5-2 Variations and Extremes in Meteorological Measurements Across the SNL/NM

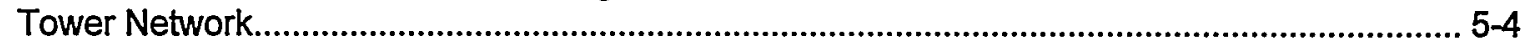

5-3 1997 Criteria Pollutant Results as Compared to Regulatory Standards .................................... 5-9

5-4 Quarterly and Annual Averages of $\mathrm{PM}_{10}$ at SNL/NM for 1997 ........................................... 5-10

5-5 $\quad \mathrm{PM}_{10}$ Sample Analyses Conducted at the Five PM Monitors and the CPMS Site ..................... 5-10

5-6 $\quad \mathrm{PM}_{10}$ Average Annual Metals Concentration by Station Location ........................................... 5-11

5-7 VOC Average Concentration by Station Location Compiled from Monthly Results ................... 5-13

5-8 Summary of Radionuclide Releases from the 15 NESHAP Sources in 1997 .......................... 5-17

5-9 Annual Source-Specific Effective Dose Equivalent (EDE) to Offsite Receptors .......................... 5-20

5-10 Annual Effective Dose Equivalent (EDE) to Onsite Receptors.............................................. 5-21

5-11 Calculated Dose Assessment Results for Onsite and Offsite Receptors and for Collective Populations 
TABLES (Concluded)

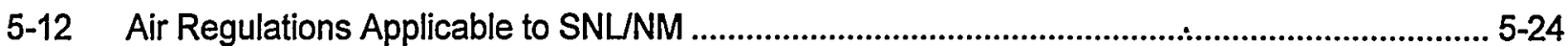

5-13 Important Documents for All Air Quality Programs at SNL/NM ........................................... 5-28

6-1 SNL/NM Wastewater Discharge Permits and Station Characteristics ........................................ 6-3

6-2 Primary Regulatory Drivers for the Wastewater Discharge Program ....................................... 6-3

6-3 Important Documents for the Wastewater Discharge Program .................................................6.5

6-4 Primary Regulatory Drivers for the Surface Discharge Program...............................................6.6.6.6.

6-5 Important Documents for the Surface Discharge Program............................................................. 6-6

6-6 Primary Regulatory Drivers for the Storm Water Program ......................................................... 6-7

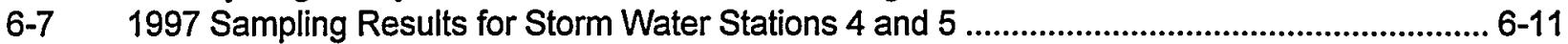

6-8 Important Documents for the Storm Water Program ........................................................... 6-12

7-1 Regulations Specific to the Groundwater Protection Program and the ER Project..................... 7-3

7-2 Guidelines Used for Groundwater Quality Sample Comparisons ............................................. 7-11

7-3 Sampling Frequency for Groundwater Quality Monitoring at SNL/NM During 1997 .................. 7-11 


\section{Abbreviations}

\section{Acronyms and Abbreviations}

\begin{tabular}{|c|c|}
\hline $\begin{array}{l}\text { ABC/AQCB } \\
\text { ACRR }\end{array}$ & $\begin{array}{l}\text { Albuquerque-Bernalillo County Air Quality Control Board } \\
\text { Annular Core Research Reactor }\end{array}$ \\
\hline AEA & Atomic Energy Act \\
\hline AEHD & Albuquerque Environmental Health Department \\
\hline AIRFA & American Indian Religious Freedom Act \\
\hline ALARA & as low as reasonably achievable \\
\hline AMPL & Advanced Manufacturing Process Laboratory \\
\hline ARM & atmospheric radiation measurement \\
\hline ARPA & Archaeological Resources Protection Act \\
\hline ASER & Annual Site Environmental Report \\
\hline $\mathrm{CA}$ & Corrective Action \\
\hline CAA & Clean Air Act \\
\hline CAAA & Clean Air Act Amendments \\
\hline CAMU & Corrective Action Management Unit \\
\hline CAN & Clean Air Network \\
\hline CAP88-PC & Clean Air Act Assessment Package-1988 \\
\hline CAS & Chemical Abstract System \\
\hline CEARP & Comprehensive Environmental Assessment and Response Program \\
\hline CEQ & Council on Environmental Quality \\
\hline CERCLA & Comprehensive Environmental Response, Compensation, and Liability Act \\
\hline CERF & Civil Engineering Research Facility \\
\hline CFR & Code of Federal Regulations \\
\hline CNSAC & Center for National Security and Arms Control \\
\hline COA & City of Albuquerque \\
\hline COD & chemical oxygen demand \\
\hline CPMS & Criteria Pollutant Monitoring Station \\
\hline CWA & Clean Water Act \\
\hline CWL & Chemical Waste Landfill \\
\hline CWPM & Chemical Waste Landfill Air Monitoring Station \\
\hline $\mathrm{CY}$ & calendar year \\
\hline $\mathrm{D} \& \mathrm{D}$ & demolition and decontamination \\
\hline DCE & cis 1,2-dichloroethene \\
\hline DCG & derived concentration guide \\
\hline DOC & U.S. Department of Commerce \\
\hline DOE & U.S. Department of Energy \\
\hline DOE/AL & U.S. Department of Energy/Albuquerque Operations Office \\
\hline DOE/EH & U.S. Department of Energy/Environmental Health \\
\hline DOE/EM & U.S. Department of Energy/Office of Environmental Management \\
\hline $\mathrm{DOE} / \mathrm{HQ}$ & U.S. Department of Energy/Headquarters \\
\hline DOE/KAO & U.S. Department of Energy/Kirtland Area Office \\
\hline DOT & U.S. Department of Transportation \\
\hline DP & Discharge Plan \\
\hline DQO & data quality objective \\
\hline DU & depleted uranium \\
\hline
\end{tabular}




\section{AbBreviATIONS (Continued)}

\begin{tabular}{|c|c|}
\hline $\begin{array}{l}\text { EA } \\
\text { ECF }\end{array}$ & $\begin{array}{l}\text { Environmental Assessment } \\
\text { Explosive Components Facility }\end{array}$ \\
\hline ECL/ADM & Environmental Checklist/Action Description Memorandum \\
\hline EDE & effective dose equivalent \\
\hline EG\&G & Edgerton, Germeshausen \& Grier Corporation \\
\hline EHS & extremely hazardous substance \\
\hline EIS & Environmental Impact Statement \\
\hline EIS/ODIS & Effluent Information System/Onsite Discharge Information System \\
\hline EMD & Emergency Management Division \\
\hline EMSL & Environmental Monitoring Systems Laboratory \\
\hline EO & Executive Order \\
\hline EOD & Explosive Ordnance Disposal \\
\hline EPA & U.S. Environmental Protection Agency \\
\hline EPCRA & Emergency Planning and Community Right-to-Know Act \\
\hline ER & Environmental Restoration (Project) \\
\hline ERDA & Energy Research and Development Administration \\
\hline ESA & Endangered Species Act \\
\hline ES\&H & Environment, Safety, and Health \\
\hline FFCAct & Federal Facilities Compliance Act \\
\hline FIFRA & Federal Insecticide, Fungicide, and Rodenticide Act \\
\hline FONSI & Finding of No Significant Impact \\
\hline FR & Federal Register \\
\hline FY & fiscal year \\
\hline GIF & Gamma Irradiation Facility \\
\hline GSA & General Services Administration \\
\hline GSAF & Generator Set-Aside Fee \\
\hline GWPP & Groundwater Protection Program \\
\hline HAP & hazardous air pollutant \\
\hline $\mathrm{HCF}$ & Hot Cell Facility \\
\hline HCFC & hydrochlorofluorocarbon \\
\hline HDRV & Historical Disposal Requests Validation (Project) \\
\hline HERMES & High-Energy Radiation Megavolt Electron Source \\
\hline HLW & high -level radioactive waste \\
\hline HSWA & Hazardous and Solid Waste Amendments (RCRA) \\
\hline HWMF & Hazardous Waste Management Facility \\
\hline ICP & inductively coupled plasma \\
\hline ICS & Incident Command System \\
\hline IMRL & Integrated Materials Research Laboratory \\
\hline INEEL & Idaho National Engineering and Environmental Laboratories \\
\hline IRP & Installation Restoration Program \\
\hline ISMS & Integrated Safety Management System \\
\hline ISS & Interim Storage Site \\
\hline
\end{tabular}


AbBreviations (Continued)

IT

ITRI

KAFB

KTF

KUMSC

KUPM

LANL

LDR

LECS

LRRI

LIHE

LLW

LMF

LWDS

MAC

MCL

MEI

MDA

MDL

MDL

MIPP

MSDS

MSL

MW

MWL

MWPM

NA

NAAQS

ND

NEPA

NESHAP

NFA

NGF

NHPA

NM

NMAC

NMDOA

NMED

NMWQCC

NOAA
International Technology Corporation

Inhalation Toxicology Research Institute (now LRR!)

Kirtland Air Force Base

Kauai Test Facility

Kirtland Underground Munitions Storage Complex

Kirtland Utilized Particulate Matter (air quality station)

Los Alamos National Laboratory

Land Disposal Restrictions

Liquid Effluent Control System

Lovelace Respiratory Research Institute

Light Initiated High Explosives (Facility)

low-level radioactive waste

Large-Scale Melt Facility

Liquid Waste Disposal System

maximum allowable concentration

maximum contaminant level

maximally exposed individual

minimum detectable activity

minimum detection level

Microelectronics Development Laboratory

Medical Isotope Production Project

Material Safety Data Sheet

Melting and Solidification Laboratory

mixed waste

Mixed Waste Landfill

Mixed Waste Landfill Air Monitoring Station

not available or not applicable

National Ambient Air Quality Standards

not detected

National Environmental Policy Act

National Emission Standards for Hazardous Air Pollutants

No Further Action

Neutron Generator Facility

National Historic Preservation Act

New Mexico

New Mexico Administrative Code

New Mexico Department of Agriculture

New Mexico Environment Department

New Mexico Water Quality Control Commission

National Oceanographic and Atmospheric Administration 


\section{AbBreviations (Continued)}

\begin{tabular}{|c|c|}
\hline NON & Notification of Noncompliance \\
\hline NPDES & National Pollutant Discharge Elimination System \\
\hline NPL & National Priorities List \\
\hline NRC & National Response Center - (1-800-424-8802) \\
\hline NRC & U.S. Nuclear Regulatory Commission \\
\hline NRHP & National Register of Historic Properties \\
\hline NSPS & New Source Performance Standards \\
\hline NTNC & Non-Transient, Non-Community \\
\hline NTS & Nevada Test Site \\
\hline ODS & ozone-depleting substance \\
\hline OPOL & Open Pool Burn Site Facility \\
\hline ORPS & Occurrence Reporting Processing System \\
\hline OU & Operable Unit \\
\hline $\mathrm{P} 2$ & Pollution Prevention \\
\hline P4 & Pollution Prevention in Permitting Pilot (Project) \\
\hline PAVI & Preliminary Assessment/Site Inspection \\
\hline PBFA & Particle Beam Fusion Accelerator \\
\hline PBR/SDP & Packed Bed Reactor/Silent Discharge Plasma \\
\hline PCB & polychlorinated biphenyl \\
\hline PETL & Processes Environmental Testing Laboratory \\
\hline$P G$ & Program (Document) \\
\hline PM & particulate matter \\
\hline$P M_{10}$ & respirable particulate matter (diameter equal to or less than 10 microns) \\
\hline $\mathrm{PM}_{2.5}$ & respirable particulate matter (diameter equal to or less than 2.5 microns) \\
\hline PMRF & Pacific Missile Range Facility \\
\hline POTW & publicly owned treatment works \\
\hline PPE & personal protective equipment \\
\hline PPOA & Pollution Prevention Opportunity Assessment \\
\hline PQL & practical quantitation limit \\
\hline PSD & Prevention of Significant Deterioration \\
\hline QA & quality assurance \\
\hline QAP & Quality Assurance Program \\
\hline $\begin{array}{l}\text { QAPjP } \\
\text { QC }\end{array}$ & $\begin{array}{l}\text { Quality Assurance Project Plan } \\
\text { quality control }\end{array}$ \\
\hline RCRA & Resource Conservation and Recovery Act \\
\hline RFI & RCRA Facility Investigation \\
\hline $\mathrm{RH}$ & relative humidity \\
\hline RMMA & Radioactive Material Storage Areas \\
\hline RMSEL & Robotic Manufacturing Science and Engineering Laboratory \\
\hline RMSY & Radioactive Materials Storage Yard \\
\hline RMWMF & Radioactive and Mixed Waste Management Facility \\
\hline ROD & Record of Decision \\
\hline $\mathrm{RC}$ & n on Investment \\
\hline
\end{tabular}




\section{AbBreviations (Continued)}

$\mathrm{RQ}$

RSI

RWL

SABRE

SAF

SAP

SARA

SATURN

SDWA

SFR

SHPO

SIC

SLAMS

SMCL

SMERF

SGS

SMO

SNL

SNL/CA

SNL/NM

SPCC

SPDES

SPR

STAR

STAR

STEL

SVOC

SWEIS

SWISH

SWMU

SWTF

TA

TANDEM

TCE

TCLP

TDS

TLD

TLV

TNMHC

TOC

TOX

TRE

TRI

TRU

TSCA

T/S/D

TSP reportable quantity

RCRA Site Investigation

Radiological Waste Landfill

Sandia Accelerator Beam Research Experiment

Soil Amendment Facility

sampling and analysis plan

Superfund Amendments and Reauthorization Act

(an accelerator facility)

Safe Drinking Water Act

South Fence Road

State Historic Preservation Officer

Standard Industrial Classification

state and local air monitoring stations

secondary maximum containment level

SMoke Emission Reduction Facility

Segmented Gate System

Sample Management Office

Sandia National Laboratories

Sandia National Laboratories/California

Sandia National Laboratories/New Mexico

Spill Prevention Control and Countermeasures (Plan)

State Pollutant Discharge Elimination System

Sandia Pulsed Reactor

Stability Array (NESHAP data decks)

Sample Tracking Analytical Results (QA database)

Short-Term Exposure Limit

Semi Volatile Organic Compound

Site-Wide Environmental Impact Statement

Small Wind SHielded (facility)

Solid Waste Management Unit

Solid Waste Transfer Facility

Technical Area

(an accelerator facility)

trichloroethylene or trichloroethene

toxicity characteristic leaching procedure

total dissolved solids

thermoluminescent dosimeter

threshold limit value

total non-methane hydrocarbon

total organic carbon

total organic halogen

Thunder Range East

Toxic Release Inventory

transuranic

Toxic Substances Control Act

treatment, storage, and disposal (facility)

total suspended particulates 


\section{AbBreviations (Continued)}

TSS

TTF

TTR

TU

TWA

USAF

U.S.C.

USGS

USNRC

UST

VCM

VOC

WAC

WERF

WIPP total suspended solids

Thermal Treatment Facility

Tonopah Test Range

Temporary Unit

time weighted average

United States Air Force

United States Code

United States Geological Survey

United States Nuclear Regulatory Commission

underground storage tank

voluntary corrective measure

volatile organic compound

waste acceptance criteria

Waste Experimental Reduction Facility

Waste Isolation Pilot Plant 


\section{AbBreviations (Continued)}

\section{Units of Measure}

$\begin{array}{ll}{ }^{\circ} \mathrm{C} & \text { Celsius degree } \\ \mathrm{cm} & \text { centimeter } \\ { }^{\circ} \mathrm{F} & \text { Fahrenheit degree } \\ \mathrm{ft} & \text { feet } \\ \mathrm{g} / \mathrm{m}^{3} & \text { grams per cubic meter } \\ \mathrm{g} & \text { gram } \\ \mathrm{gal} & \text { gallon } \\ \mathrm{hr} & \text { hour } \\ \mathrm{in} & \text { inches } \\ \mathrm{kg} & \text { kilogram } \\ \mathrm{km} & \text { kilometer } \\ \mathrm{kW} & \text { kilowatt } \\ \mathrm{l} & \text { liter } \\ \mathrm{lb} & \text { pound } \\ \mathrm{m} & \text { meter } \\ \mathrm{m} & \text { square meter } \\ \mathrm{m}^{3} & \text { cubic meter } \\ \mathrm{MBtu} & \text { million British thermal units } \\ \mathrm{mg} / \mathrm{l} & \text { milligrams per liter } \\ \mathrm{mi} & \text { miles } \\ \mathrm{ml} & \text { milliliter } \\ \mathrm{ppb} & \text { parts per billion } \\ \mathrm{ppm} & \text { parts per million } \\ \mathrm{sq} \mathrm{ft} & \text { square feet } \\ \mathrm{sq} \mathrm{km} & \text { square kilometer } \\ \mathrm{sq} \mathrm{mi} & \text { square mile } \\ \mathrm{tpy} & \text { tons per year } \\ \mathrm{yr} & \text { year } \\ \mu \mathrm{gg} / \mathrm{m}^{3} & \text { micrograms per cubic meter } \\ \mu \mathrm{m} & \text { micron } \\ \mu \mathrm{gg} / \mathrm{g} & \text { micrograms per gram } \\ \mu \mathrm{g} / \mathrm{l} & \text { micrograms per liter } \\ & \end{array}$

\section{Radioactivity Measurements}

$\begin{array}{ll}\mathrm{Ci} & \text { curie } \\ \mathrm{mrem} & \text { millirem (unit of radiation dose) } \\ \mathrm{mSv} & \text { millisievert (unit of radiation dosage) } \\ \text { person-rem } & \text { radiation dose to population (also man-rem) } \\ \text { person-Sv } & \text { person-sievert (unit of radiation dosage) } \\ \mathrm{pCi} & \text { picocurie } \\ \mathrm{rem} & \text { roentgen equivalent man } \\ \mu \mathrm{Ci} & \text { microcurie } \\ \mu \mathrm{Ci} / \mathrm{MJ} & \text { microcuries per megajoule }\end{array}$




\section{AbBreviations (Continued)}

\section{Chemical Abbreviations}

$\begin{array}{ll}\mathrm{CO} & \text { carbon monoxide } \\ \mathrm{DCE} & \text { cis-1,2-dichloroethene } \\ \mathrm{NO}_{2} & \text { nitrogen dioxide } \\ \mathrm{NO}_{\mathrm{x}} & \text { nitrogen oxides } \\ \mathrm{O}_{3} & \text { ozone } \\ \mathrm{pH} & \text { potential of hydrogen } \\ \mathrm{SO}_{2} & \text { sulfur dioxide } \\ \mathrm{TCE} & \text { trichloroethylene or } \\ & \text { trichloroethene } \\ \mathrm{TCA} & \text { trichloroethane } \\ \mathrm{HF} & \text { hydrofluoric acid } \\ 1,1,1,-\mathrm{TCA} & 1,1,1, \text {-trichloroethane } \\ \text { TNMHC } & \text { total non-methane hydrocarbon }\end{array}$

\section{Approximate Conversion Factors For Selected SI (Metric) Units}

\begin{tabular}{|l|c|l|}
\hline \multicolumn{1}{|c|}{ Multiply SI (Metric) Unit } & By & \multicolumn{1}{|c|}{$\begin{array}{c}\text { To Obtain U.S. } \\
\text { Customary Unit }\end{array}$} \\
\hline Cubic meters $\left(\mathrm{m}^{3}\right)$ & 35 & Cubic feet $\left(\mathrm{ft}^{3}\right)$ \\
\hline Centimeters $(\mathrm{cm})$ & 0.39 & Inches (in.) \\
\hline Meters $(\mathrm{m})$ & 3.3 & Feet (ft) \\
\hline Kilometers $(\mathrm{km})$ & 0.62 & Miles (mi) \\
\hline Square kilometers $\left(\mathrm{km}^{2}\right)$ & 0.39 & Square miles $\left(\mathrm{mi}^{2}\right)$ \\
\hline Hectares (ha) & 2.5 & Acres \\
\hline Liters $(\mathrm{l})$ & 0.26 & Gallons (gal) \\
\hline Grams $(\mathrm{g})$ & 0.035 & Ounces (oz) \\
\hline Kilograms $(\mathrm{kg})$ & 2.2 & Pounds (lb) \\
\hline Micrograms per gram $(\mu \mathrm{g} / \mathrm{g})$ & 1 & Parts per million $(\mathrm{ppm})$ \\
\hline Milligrams per liter $(\mathrm{mg} / \mathrm{l})$ & 1 & Parts per million (ppm) \\
\hline Celsius ( $\left.{ }^{\circ} \mathrm{C}\right)$ & ${ }^{\circ} \mathrm{F}=9 / 5^{\circ} \mathrm{C}+32$ & Fahrenheit ( $\left.{ }^{\circ} \mathrm{F}\right)$ \\
\hline
\end{tabular}




\section{Sandia National Laboratories}

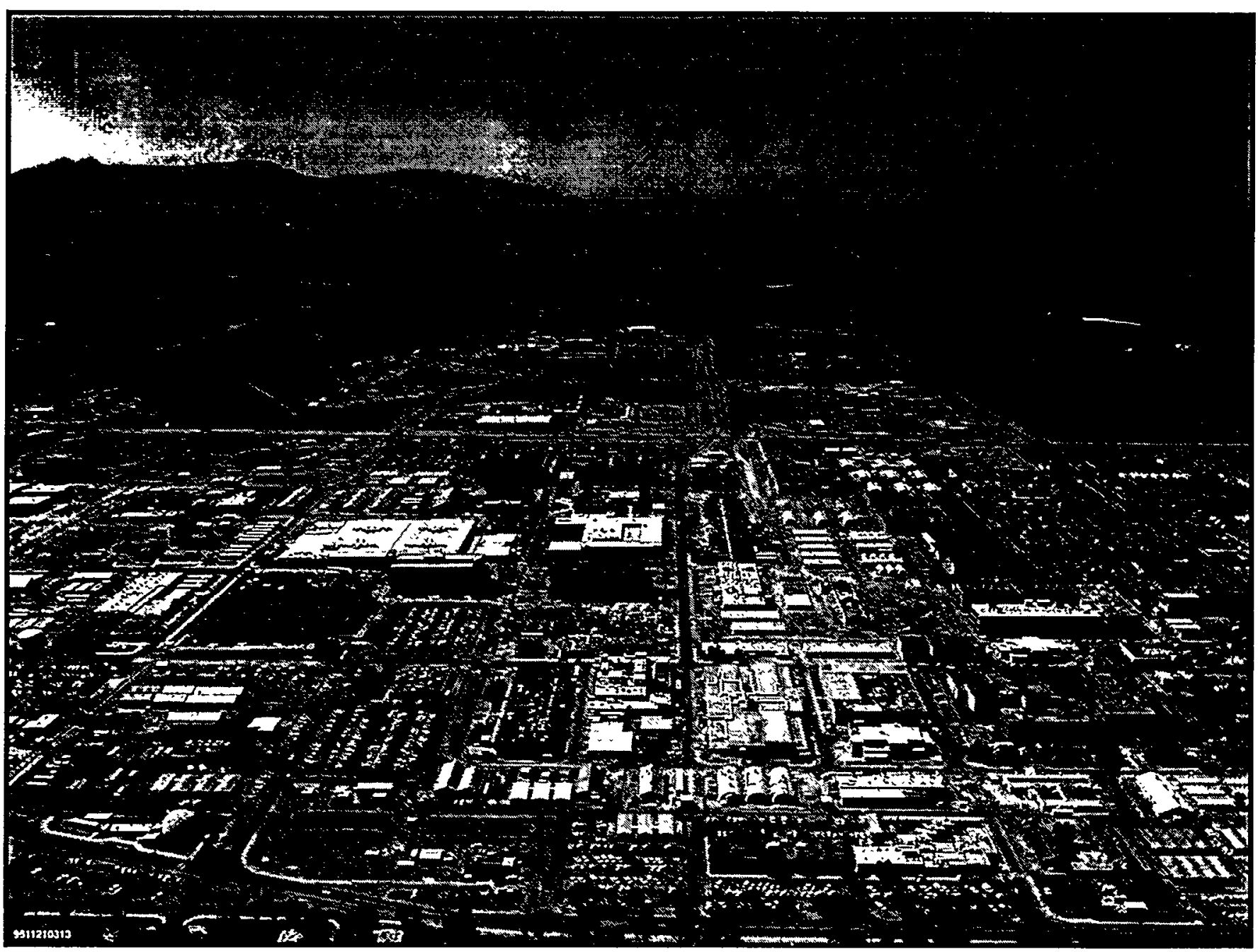

Aerial View of SNL/NM, Technical Area I, Technical Area II, and Technical Area IV, Looking Due South 


\section{EXECUTIVE SummarY}

$A \begin{aligned} & \text { s required by U.S. Department of } \\ & \text { Energy (DOE) Order 5400.1, General } \\ & \text { Environmental Protection Program }\end{aligned}$ (DOE 1990a), this Annual Site Environmental Report (ASER) has been prepared for Sandia National Laboratories/New Mexico (SNL/NM) to characterize current environmental conditions in the vicinity of SNL/NM property and to summarize the compliance status with federal, state, and local requirements and permits. This report represents a key component of the DOE's effort to keep the public informed about environmental conditions throughout the DOE complex. For this 1997 calendar year (CY97) report, significant environmental program achievements are highlighted, as well as noting any areas of noncompliance, corrective actions, or other areas of ongoing improvements. Audit results from all external appraisals conducted in 1997 are briefly described.

SNL/NM is managed and operated by Sandia Corporation, a wholly owned subsidiary of Lockheed Martin Corporation. The site is located on the 80-square-mile Kirtland Air Force Base (KAFB) military complex, which includes 20,486 acres withdrawn from the U.S. Forest Service for various remote testing activities conducted by DOE, SNL, and the U.S. Air Force (USAF). The complex is situated adjacent to and approximately $10.5 \mathrm{~km}(6.5 \mathrm{mi})$ southeast of downtown Albuquerque, New Mexico.

The primary mission of SNL/NM is to conduct research and development for nuclear weapon system components and to ensure the integrity and reliability of the nation's defense systems. This mission has greatly expanded in recent years to focus on the development of nonweapon-specific technology such as microelectronics, micro-machines, computer technology, waste treatment technologies, accelerator and pulsed power energy research, robotics, and biomedical engineering. The Environment, Safety, and Health (ES\&H) Center within SNL/NM supports the corporate mission by providing compliance support to line organization activities. SNL/NM's operations primarily take place within five technical areas (TA-1 through TA-V) and some remote test locations within the withdrawn area of KAFB.

The major environmental programs and activities conducted at SNL/NM during 1997 are as follows:

- Waste management

- Pollution Prevention (P2) and waste minimization

- Environmental Restoration (ER)

- Terrestrial surveillance

- Water quality for effluents and runoff

- Groundwater monitoring

- Air quality compliance and monitoring

- National Environmental Policy Act (NEPA) activities

- Environmental occurrence reporting

- Environmental audit results

WASTE MANAGEMENT, P2, AND WASTE MINIMIZATION

Waste management at SNL/NM is conducted at three primary waste handling areas: the Hazardous Waste Management Facility (HWMF), the Radioactive and Mixed Waste Management Facility (RMWMF), and the Solid Waste Transfer Facility (SWTF). In addition, representatives from SNL/NM's waste minimization and P2 programs confer with SNL/NM's line organizations to implement waste minimization technologies and recycling, wherever feasible.

- HWMF - The HWMF operates under a Resource Conservation and Recovery Act 
(RCRA) Part B Permit. All nonradioactive, nonexplosive, hazardous chemical wastes, including RCRA waste, asbestos, polychlorinated biphenyls (PCBs), and biohazardous waste, are handled at this facility. Recycling is also carried out for various material categories that include used oil, specific metals, batteries, and PCBs. The HWMF is responsible for verifying, labeling, packaging, storing, and shipping waste to permitted facilities for disposal. A total of 18,625 individual items were collected and cataloged at the HWMF in 1997. The HWMF shipped out the following waste categories:

\begin{tabular}{rll} 
Weight $(\mathrm{kg})$ & Category \\
\hline 50,153 & RCRA Waste \\
155,951 & Asbestos \\
28,591 & PCBs \\
344,334 & ER Waste (non-rad) \\
2,355 & Biohazardous Waste \\
132,462 & Other Recycled or \\
& Chemical Waste & \\
\hline 713,846 & Total Shipped
\end{tabular}

The New Mexico Environment Department (NMED) conducted an audit of the facility's operations and waste generator sites in June 1997; one violation was found at the HWMF involving a paperwork error.

- RMWMF - The RMWMF currently handles primarily low-level waste (LLW) and mixed waste (MW). In 1997, SNL/NM generated:

\begin{tabular}{cl} 
Weight (kg) & Category \\
332,731 & LLW \\
5,515 & MW \\
0.5 & Transuranic (TRU) \\
\hline $338,246.5$ & Total Generated
\end{tabular}

No radioactive waste was received from offsite facilities in 1997. MW continues to be a compliance issue due to the storage of MW onsite past the maximum 1-year RCRA time frame. MW treatment technologies have been developed and implemented to address the problem. In early 1998, the first shipment of MW (18.5 cubic meters $\left[\mathrm{m}^{3}\right]$ ) was made to an incineration facility at the Idaho National Engineering and Environmental Laboratories (INEEL). SNL/NM has remained in compliance with the Federal Facilities Compliance Act (FFCAct), which acknowledged and made provisions for the national lack of MW treatment capabilities for federal facilities.

- SWTF - The SWTF accepts non-hazardous solid waste generated from SNL/NM's offices and laboratories. The waste is screened for acceptance criteria and then compacted, baled, and stored for shipment to recylcing centers or area landfills. Recyclable material handling makes up a large portion of the facility's activities. In 1997 , a total of $1,091,617 \mathrm{~kg}$ of waste was received at the facility; $644,977 \mathrm{~kg}$ of this total was recyclable paper and cardboard. Plans to expand the recycling effort to include other categories are under way.

- $\quad$ P2 - Waste minimization and P2 efforts at SNL/NM take on several forms. Pollution Prevention Opportunity Assessments (PPOAs) assess and identify areas of waste production that can be reasonably reduced through modification of existing processes and/or equipment. PPOAs may be used to identify potential Return-on-Investment (ROI) projects, which are funded by DOE. ROIs are initiated for projects that can show a profitable waste management cost savings over 2 years by modification of the existing methods. There were five projects proposed for ROI funding in 1997.

There is also a Generator Set-Aside Fee (GSAF) piloted by the DOE. A small fee is collected from waste generators based on their waste quantity and used for $\mathrm{P} 2$ project funding. For example, GSAF money was used to optimize the Steam Plant operations to reduce air emissions. 


\section{ENVIRONMENTAL RESTORATION (ER) PROJECT ACTIVITIES}

The assessment and remediation of potential release sites identified by the ER Project at SNL/NM are being regulated by the NMED as provided for by the Hazardous and Solid Waste Amendments of 1984 (HSWA) Module IV of the RCRA Part B Operating Permit. At the close of fiscal year 1997 (FY97), there were 146 sites remaining to be addressed. Many of these sites will require no further action due to the completion of voluntary cleanup measures or because any contamination present is below regulatory action levels. During FY97, four corrective actions were completed and seven sites were approved for No Further Action (NFA). The Chemical Waste Landfill (CWL) in TA-III is the most significant ER site remaining to be remediated. Remedial action for all SNL/NM sites is scheduled to be completed by the year 2001 .

To facilitate the storage and treatment of ER waste, a Temporary Unit (TU) and Corrective Action Management Unit (CAMU) are under construction and expected to be operational in 1998. The TU/CAMU facility will allow for the treatment and storage of chemicallycontaminated soils, mostly generated from the CWL. The CAMU is designed to remove volatile organic chemicals and remove or stabilize metals. Treated soil that meets regulatory land disposal standards will be buried onsite in specially constructed disposal cells.

\section{TERRESTRIAL SURVEILLANCE}

SNL/NM conducts terrestrial surveillance as required by DOE Order 5400.1 (DOE 1990a). Soil, sediment, vegetation, and surface water samples are collected from onsite, perimeter, and offsite locations. Sample locations are in areas of known contamination or in areas where contamination, if present, would be expected to accumulate. The surveillance sampling objectives are to detect any potential releases and/or migration of contaminated material to offsite locations as well as to determine if pollutants are migrating from offsite to onsite. Results have been categorized into four categories. A Category 1 location - of which SNL/NM has none-would be a site which showed higher than offsite or perimeter values and an increasing trend. At the other end of the scale, Category 4 locations would show no statistical differences between onsite and offsite/perimeter locations. Results in 1997 identified several locations with higher than offsite values (but no increasing trends) in areas of known contamination. Results were similar to past years. Tritium contamination at levels higher than offsite is present in TA-II and near the Mixed Waste Landfill (MWL) in TA-III. Cesium-137 has been found higher than offsite in four areas near the land withdrawal, on the east side of KAFB, and in TA-III. Cadmium, cobalt, lead, magnesium, manganese, and zinc were found in concentrations higher than offsite and perimeter locations at several locations throughout the sampling area.

The Terrestrial Surveillance Program conducted its annual wildlife monitoring survey in 1997 to ascertain the presence of contaminants in rodent populations and to augment baseline data for general species information on mammals, birds, reptiles, amphibians, and vegetation.

\section{WATER QUALITY MONITORING}

Water quality programs include wastewater effluents, storm water runoff, and groundwater monitoring.

- Sewer System Discharges - Wastewater from SNL/NM is discharged through four general outfall stations. Additionally, there are two pretreatment stations upstream of the general outfalls for the Advanced Manufacturing Process Laboratory (AMPL) and the Microelectronics Development Laboratory. (MDL). In 1997, the AMPL station became a zero discharge location. Monitoring is conducted to ensure that 
wastewater discharges meet the standards of the Albuquerque Sewer Treatment Plant, which treats city and SNL/NM wastewater. Treated water is eventually discharged to the Rio Grande. There were three instances of $\mathrm{pH}$ excursions outside of permitted limits in 1997. No fines were incurred.

- Surface Discharges - All water to be discharged to the ground surface, either directly or to lined containments, must meet state surface discharge standards. There were 36 requests made for individual discharges to the ground surface. Seven were not approved and sent to the sanitary sewer authority for disposal. Additionally, routine surface discharges are made to the evaporation lagoons servicing the Pulsed Power Facility under an existing discharge permit. All permit requirements were met in 1997 for this facility. There were five instances of inadvertent surface water discharge releases in 1997. No fines were incurred.

- Storm Water Runoff - SNL/NM received its "Multi-Sector General Permit" under the National Pollutant Discharge and Elimination System (NPDES) regulations in August 1997. The original "Individual Permit" application was never acted upon by the Environmental Protection Agency (EPA). The new permit requires only two storm water monitoring stations and has a streamlined list of sampling parameters. Results from the one sample taken in 1997 indicated higher than acceptable levels for zinc and lead. The source of the apparent contaminants was not located. Since one data point is inconclusive, future monitoring will attempt to gather more representative samples. If results continue to be high for these or other parameters, further investigations to determine the source will be carried out.

- Groundwater Monitoring - Groundwater monitoring activities reported are those associated with SNL/NM's ER Project and the Groundwater Protection Program (GWPP).

In 1997, the Groundwater Surveillance Task of the GWPP sampled nine wells and one spring. Water quality data showed several metals slightly exceeded the maximum contaminant limits (MCLs) set for drinking water standards. These included beryllium, nickel, iron, and thallium. Elevated nickel is likely a result of deteriorating well screens. Some of these metals also occur naturally high in these areas. No significant environmental impacts were found.

ER results were divided into four areas: Chemical Waste Landfill (CWL), Mixed Waste Landfill MWL), TA-V, and Sandia North (near TA-I and TA-II). In 1997, water quality samples taken at ER sites, as required by the RCRA permit, showed elevated levels of known contaminants similar to past years. This includes trichloroethylene (TCE) at the CWL, TA-V, and Sandia North. The concentrations of TCE are at low levels not exceeding 21 micrograms/liter $(\mu \mathrm{g} / \mathrm{l})$, as compared to the drinking water MCL of $5 \mu \mathrm{g} / \mathrm{l}$. The MWL showed elevated levels of chromium (1.1 $\mathrm{mg} / \mathrm{l})$ that were about 10 times higher than the $0.1 \mathrm{mg} / \mathrm{l}$ standard. Nickel and antimony were elevated at the CWL. However, elevated nickel in most wells is due to well screen corrosion. Nitrates are also present at Sandia North and TA-V. Sandia North has the more significant nitrate contamination of the two sites, but is only about two times higher than the drinking water standards. There is no indication that contaminants are migrating from any of SNL/NM's ER sites.

Water levels were also recorded in 123 wells to determine the potentiometric surface (subsurface water table levels and general flow directions). Water levels are continuing to drop at a rate of 1 to $2 \mathrm{ft}$ per year in wells west of the Tijeras fault complex, in the Santa Fe Group aquifer. 
Water level declines are the result of pumping from City of Albuquerque (COA) and KAFB water supply wells.

\section{AIR QUALITY COMPLIANCE AND MONITORING}

- Ambient Air Monitoring - SNL/NM measures ambient air quality at six stations throughout the site to compare to the National Ambient Air Quality Standards (NAAQS) and local ambient air standards implemented by New Mexico regulations. The network includes one Criteria Pollutant Monitoring Station (CPMS)-which measures sulfur dioxide $\left(\mathrm{SO}_{2}\right)$, nitrous oxides $\left(\mathrm{NO}_{\mathrm{x}}\right)$, particulate lead, ozone $\left(\mathrm{O}_{3}\right)$, and carbon monoxide ( $\mathrm{CO}$-and air monitoring equipment for volatile organic compounds (VOCs) and particulate matter (PM) located at the other stations. There were no exceedences in ambient air quality at any of SNL/NM's six stations.

- Title V Requirements - In accordance with the new requirements of the Clean Air Act Amendments (CAAA), SNL/NM has applied for a Title V Operating Permit. SNL/NM has been determined to be a major source ( $>100$ tons per year [tpy]) for nitrous oxides $\left(\mathrm{NO}_{\mathrm{X}}\right)$. The permit will include many of the current individually permitted sources under a site-wide comprehensive permit. The Title V permit application was submitted on March 1, 1996 and is expected to be granted by March 13, 1998.

- Meteorological Monitoring - SNL/NM maintains a network of eight meteorological towers to supply onsite data in support of SNL projects, such as determining locations for air monitoring station locations. The data also serves to provide current meteorological data for emergency response information in the event of a spill or other hazardous release. The towers are instrumented at various levels to record wind speed and direction, standard deviation of horizontal wind speed (sigma theta), temperature, relative humidity, precipitation, and barometric pressure.

- National Emission Standards for Hazardous Air Pollutants (NESHAP) Compliance - In 1997, there were 15 facilities reporting NESHAP-regulated emissions. However, seven of these were insignificant enough to be excluded from NESHAP calculations. NESHAP states that only sources that contribute a dose of at least $0.1 \mathrm{millirem} / \mathrm{year}$ (mrem/yr) need to be included in the annual dose assessment. Of the eight remaining facilities with the potential to emit emissions contributing over $0.1 \mathrm{mrem} / \mathrm{yr}$, two of these were zero emission sources in $1997 . \quad$ Primary radionuclides released included tritium, nitrogen-13, oxygen-15, and argon- 41 .

The NESHAP calculated effective dose equivalent (EDE) to the maximally exposed individual (MEI) was determined to be again located at the United States Air Force (USAF) Kirtland Underground Munitions Storage Complex (KUMSC) facility. The EDE calculated for this location was $0.00077 \mathrm{mrem} / \mathrm{yr}$. The offsite MEI receptor was $0.00033 \mathrm{mrem} / \mathrm{yr}$. Results were several magnitudes less than the EPA's dose limit of 10-mrem/yr (approximately 100,000 times less). The total population dose for the 80kilometer radius surrounding SNL/NM was calculated to be 0.023 person-rem. By comparison, the population received more than 57,000 person-rem from natural background radiation. SNL/NM was in full compliance with NESHAP regulations in 1997.

\section{NEPA ACTIVITIES}

SNL/NM's NEPA activities are under the direction of DOE/Kirtland Area Office (DOE/KAO). In 1997, work continued on the Site-Wide Environmental Impact Statement (SWEIS). Two Environmental Assessments 
(EAs) were also completed, each of which was issued a Finding of No Significant Impact (FONSI). A total of 95 Environmental Checklist/Action Description Memorandums (ECL/ADMs) were completed for "NEPAtriggered" projects. All 95 projects were determined by DOE to require no further NEPA documentation.

\section{OCCURRENCE REPORTING}

There were 10 environmental occurrences in 1997 for which an occurrence report was prepared. These included a $\mathrm{pH}$ excursion to the sanitary sewer, an errosional breach in the boundaries of an ER site, one paperwork error for a burn permit, and seven releases of sewage, oil, or treated water to the ground surface. Three additional occurrences not captured in the occurrence reports included two other $\mathrm{pH}$ excursions to the sanitary sewer and a small spill of hydraulic oil. No fines were incurred for any of the 13 occurrences.

\section{ENVIRONMENTAL AUDIT RESULTS}

There were six environmental audits conducted by external agencies in 1997 .

Two audits were conducted by DOE/Albuquerque (DOE/AL) in April; one to prepare SNL/NM for an upcoming DOE Headquarters (DOE/HQ) audit and the other to assess SNL/NM's emergency preparedness. The Emergency Preparedness Audit noted some problems with the Incident Command System (ICS).

In February, DOE/HQ followed up on the "hot particle" incident from 1996 in which a small radioactive particle was left undiscovered on the sorting room floor of the RMWMF for two weeks. A total of 22 corrective actions stemming from the audit were completed. Most involved changing waste sorting and health physics survey procedures.

From June through August, DOE/HQ conducted a major audit for all Environment, Safety, and Health (ES\&H) functions and noted some concerns in the Integrated Safety Management System (ISMS). Other problems were found with ES\&H documentation, specifically, certain procedures.

The NMED performed two audits in June and October to assess waste management functions at SNL/NM. The June audit identified several violations in hazardous waste management including improper labeling, open containers, and paperwork errors. All violations were at waste generator sites except for one paper work error made at the HWMF. A final fine of $\$ 18,000$ was assessed. 
$\mathrm{T}$ This Annual Site Environmental Report (ASER) has been compiled to characterize the state of the environment in and around the Sandia National Laboratories/New Mexico (SNL/NM) site operational area for the calendar year 1997 (CY1997). The ASER summarizes all environmental program activities; encapsulates compliance status with respect to applicable federal, state, and local laws; and refers readers to more comprehensive documents, where available.

This report represents a collective effort by many SNL organizations, which are responsible for the various components of SNL/NM's total site environmental management performance. Within each program area, significant efforts and successes are highlighted, as well as indicated areas where improvement or corrective actions are ongoing.

\section{SNL/NM's Mission}

Sandia National Laboratories (SNL) is a multiprogram U.S. Department of Energy (DOE) laboratory and is operated by Sandia Corporation, a subsidiary of Lockheed Martin Corporation. SNL/NM's main facilities are in Albuquerque, New Mexico (SNL/NM) and Livermore, California (SNL/CA). Auxillary operations are conducted at the Tonopah Test Range (TTR) in Nevada, the Waste Isolation Pilot Plant in Carlsbad, New Mexico, and the Kauai Test Facility (KTF) in Hawaii.

The DOE is responsible for the federal government's nuclear weapons program and conducts research and development on energy technologies and other fundamental sciences. SNL/NM is one of DOE's primary research, development, and test laboratories.

\section{Background}

SNL/NM was established as a small operation on Kirtland Air Force Base (KAFB) in 1949 after it formally separated from Los Alamos National Laboratory (LANL). It was originally called the Z-division and was located on KAFB to support LANL's nuclear weapons development project. Today, SNL/NM operations are spread over 2,842 acres with an additional 15,003 acres that have been made available through a series of land use agreements or permits with the United States Air Force (USAF) and the U.S. Forest Service. $\mathrm{KAFB}$ is an 80 square-mile installation including 20,486 acres withdrawn from the Cibola National Forest on the east side of the base.

Initially, and for many years thereafter, SNL/NM's mission was to organize and perform engineering activities for development of nuclear and non-nuclear weapons and perform environmental testing on new weapon designs. Today, it remains one of the three national laboratories in DOE's nuclear weapons complex. Although the nuclear danger is greatly reduced in the wake of the Cold War, the United States still continues to rely on nuclear weapons as a vital military deterrent. The primary mission of SNL/NM remains to ensure the integrity and reliability of weapons systems and maintain stewardship of the nation's nuclear weapons stockpile. Current work in this area includes the weaponization of nuclear explosives (for example, the design of arming, fusing, and firing systems); safe transport and storage of radioactive materials; pulsed power and accelerator research; and arms control and nonproliferation. 
New Focus in Non-military Technologies

SNL/NM's technical emphasis has shifted to focus more resources on the development of nonmilitary technologies. Additionally, many of SNL/NM's weapons-related research activities have made significant advances in non-military applications such as in robotics, microelectronics, fusion energy research, and "supercomputer" technologies. SNL/NM has formed corporate and university ties to advance some of its nonweapons technology. For example, SNL/NM's Teraflops computer, the fastest computer on earth, is a joint development of DOE, SNL, and Intel Corporation.

Other major areas of research and development at SNL/NM include energy efficiency and renewable energy, nuclear energy, fossil energy, magnetic fusion, basic energy sciences, hazardous and radioactive material transportation, and biological and environmental research.

Environment, Safety, and Health (ES\&H) In support of SNL/NM's primary mission driven programs, ES\&H programs are in place to service other SNL organizations and ensure that the corporation meets compliance with outside regulatory agencies, DOE orders, and internal rules. The majority of environmental information provided for this report was contributed by personnel from SNL/NM's ES\&H Center.

This report focuses on the environmental impact aspects of SNL/NM's operations and the laboratory services and activities performed to ensure diligent protection of the environment. This includes waste minimization and management, pollution prevention, Environmental Restoration (ER), air and water quality monitoring, environmental surveillance, chemical management, and adherence to the National Environmental Policy Act (NEPA).

SNL/NM manages and conducts its operations in an environmentally sound manner to ensure as low as reasonably achievable (ALARA) risk levels to workers, the public, and the environment. With this philosophy, SNL has developed a strong corporate-wide culture that emphasizes environmental safety and responsibility.

\section{DOE Orders}

Major DOE environmental safeguard requirements applicable in this report are embodied in the following orders:

- DOE Order 5400.1, General Environmental Protection Program (DOE 1990a).

- DOE Order 5400.5, Radiation Protection of the Public and the Environment (DOE 1993a).

The production of an ASER is a requirement for all large DOE facilities that have the potential to impact the environment through their activities. This report represents a key component of the DOE's effort to keep the public informed about environmental conditions at DOE sites.

\section{SANDIA NATIONAL LABORATORIES OPERATIONAL AREAS}

SNL/NM operations are conducted in five technical areas and several remote test areas (Figure 1-1). The primary activities conducted within these technical areas are discussed below.

Technical Area I (TA-I) is the center for SNL/NM's administration and site support activities and the main area for research, design, manufacturing, and production of weapon system components. The facilities include laboratory and office space, maintenance areas, manufacturing facilities, and a steam plant used for facility heating. Other activities performed in TA-I are devoted to energy research programs. Notable facilities or projects located in TA-I include the Supercomputing Center, the Neutron Generator Facility (NGF), the Robotic Manufacturing 


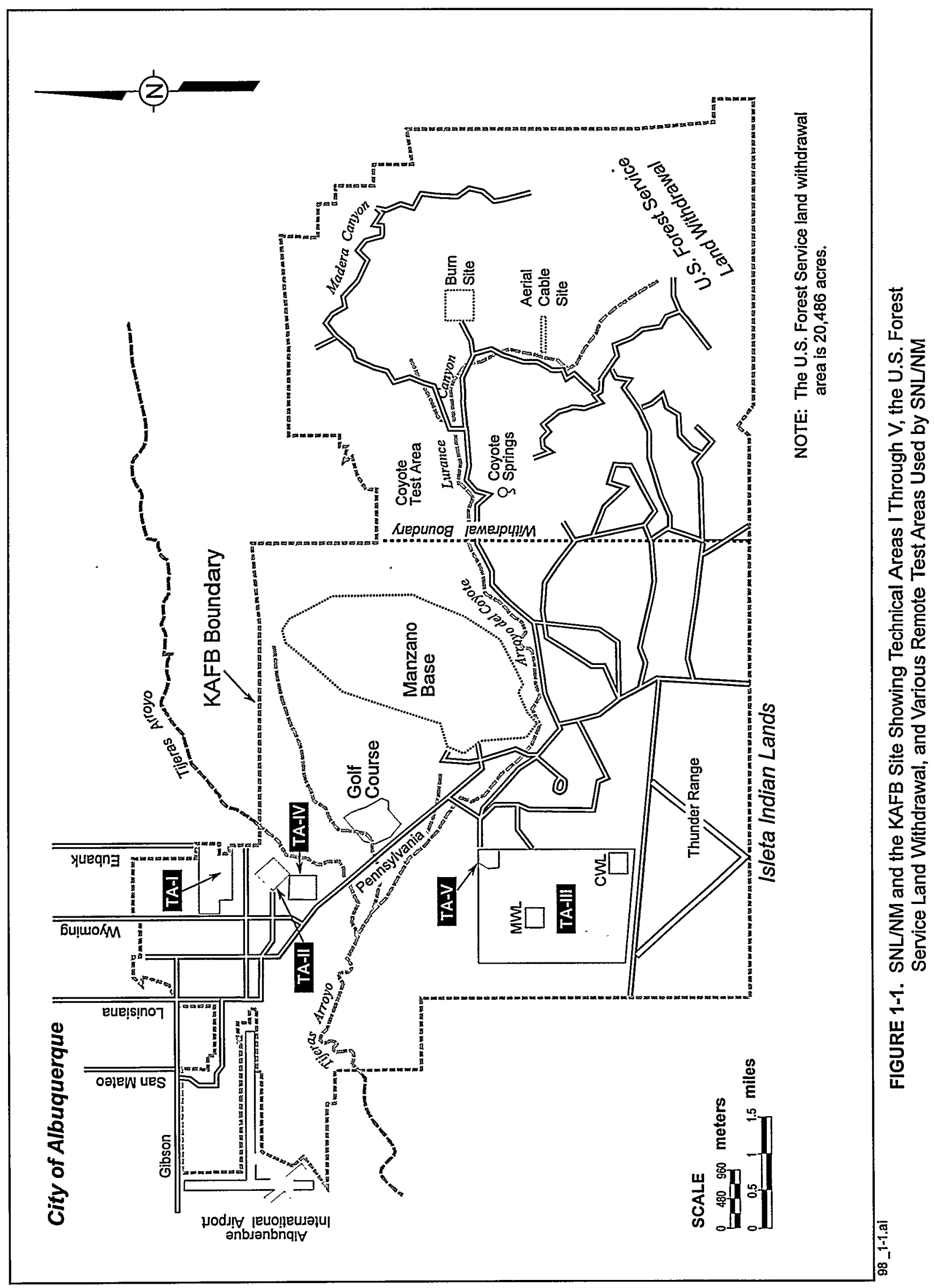


Science and Engineering Laboratory (RMSEL), the Advanced Manufacturing Process Laboratory (AMPL), and the Microelectronics Development Laboratory (MDL). The MDL has recently made major advancements in microtechnology (Figure 1-2).

The Center for National Security and Arms Control (CNSAC) is a new facility in TA-I that was opened in 1997. This state-of-the-art center will allow scientists and dignitaries from the United States and abroad to tackle the complex challenges related to national and global security. The 85,000 square-foot building is the largest secure information-management facility of its kind in the DOE complex.

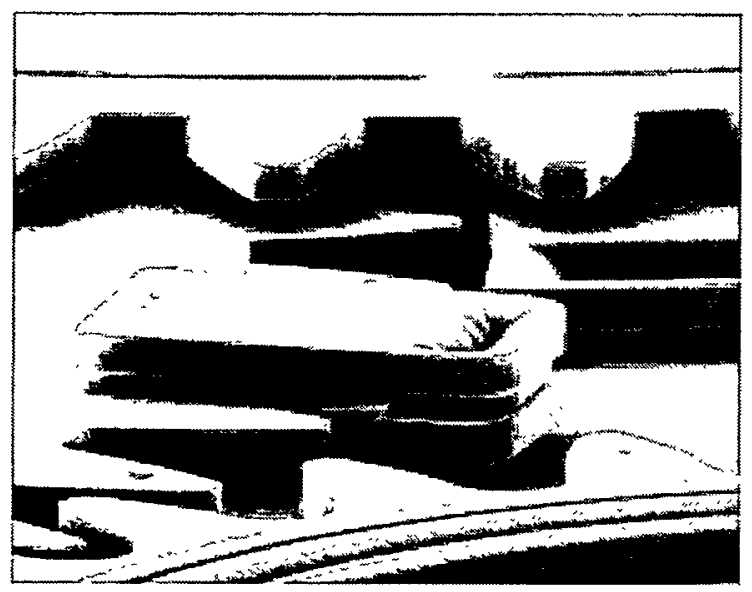

FIGURE 1-2. A Micro-transmission Developed at the MDL

The distance across the photo equals about one-third the width of a human hair. Sandia is interested in the tiny machines as near-invisible locks for nuclear weapons. They may also be useful in satellite communications, sensors, optical telescopes, and optical switching for telephone lines.

Technical Area II (TA-II) lies just south of TA-I and includes the diamond-shaped fenced compound and other facilities south of Hardin Road. TA-II facilities include the Explosive Components Facility (ECF), the Radioactive Materials Storage Yard (RMSY), the Classified Waste Landfill, the Facilities Command Center, Shipping and Receiving, the Solid Waste Transfer Facility (SWTF), and the Hazardous Waste Management Facility (HWMF). A primary activity conducted in TA-II is the testing of explosive components. Current activities in TAII include the development of land mine chemical sensing technology (Figure 1-3). Sensors are being developed to detect minute quantities of explosive molecules using ion mobility spectrometry.

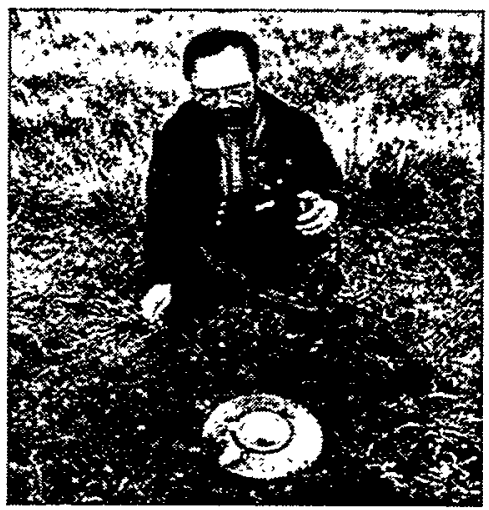

FIGURE 1-3. Sandia's Phil Rodacy Demonstrates a Mock Chemical-Sensing Detector

The new technology already has successfully analyzed both water and soil field samples in the laboratory at the ECF.

Technical Area III (TA-Im) is the largest, most remote, and furthest south of all the technical areas. It is used for large-scale environmental effects testing such as destructive testing operations using high speed impacts on sled tracks, electromagnetic effects testing, explosive testing, and gravity impact tests. Notable facilities in TA-III are the Centrifuge Facility, the Radiant Heat Facility, the Large-Scale Melt Facility (LMF); and the Melting and Solidification Laboratory (MSL). SNL/NM's Solar Tower Facility is located south of the TAIII fenced perimeter. Service and support facilities include the Radioactive and Mixed Waste Management Facility (RMWMF) and the Hammermill (a paper pulverizer used to destroy classified documents). The Mixed Waste and Chemical Waste Landfills (MWL and CWL) are the primary Environmental Restoration (ER) sites located in TA-III.

Technical Area IV (TA-IV) is the center for pulsed power research used for electromagnetic analysis and fusion studies. This area, located 
just south of TA-II is the site of the Z-Facility (formerly PBFA II), which has been modified into the world's most powerful $x$-ray source (Figure 1-4). Pulsed power technology is used to generate and apply energetic beams and highpower energy pulses. Pulsed power applications include nuclear weapon component survivability and hardness testing, $x$-ray source generation, light-ion-beam inertial confinement fusion, materials processing, waste and product sterilization, and food purification. Other accelerator and pulsed power facilities within TA-IV include the High-Energy Radiation Megavolt Electron Source III (HERMES III), used for gamma rays and advanced hydrodynamic radiography research; and the SATURN accelerator. The Simulation Technology Laboratory houses seven pulsed power accelerators. The Strategic Defense Facility is also located in TA-IV.

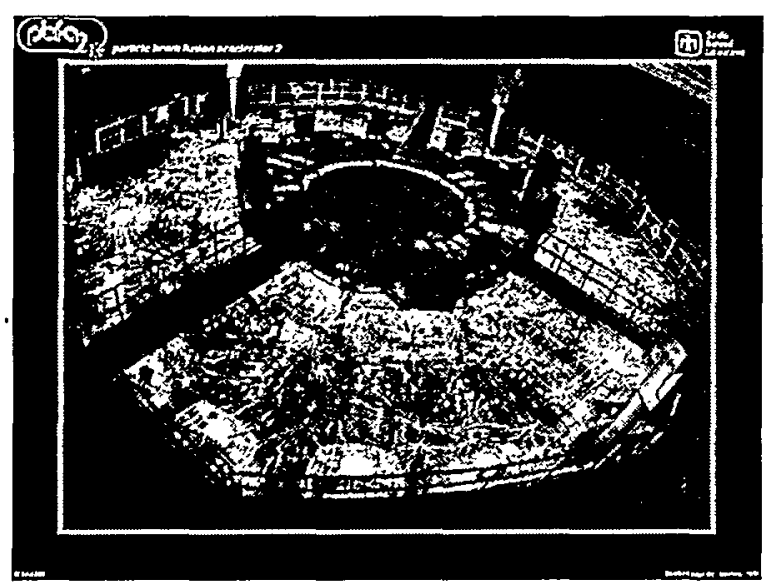

FIGURE 1-4. The Z-Facility, an Accelerator used for Nuclear Fusion Research

The Z-Facility stores electrical energy over a period of minutes then releases that energy in a concentrated burst. Thirty-six identical accelerator modules converge to produce a single, extremely short, extremely powerful pulse of energy that can be focused on a fusion target.

Technical Area V (TA-V) is located adjacent to and on the northeast end of TA-III. This high security facility routinely handles radioactive materials as part of reactor operations, such as material used in experimental research or nuclear fuels. TA-V facilities include the Sandia Pulsed Reactor (SPR) - an intense gamma irradiation facility, the Gamma Irradiation Facility, the Annular Core Research Reactor (ACRR), and the Hot Cell Facility (HCF). The ACRR and the HCF will be used to support the Medical Isotope Production Project (MIPP), which will produce pharmaceutical grade molybdenum- 99 .

Remote Test Areas are located south of TA-III and within the canyons and foothills of the land withdrawal. These include Lurance Canyon, Thunder Range, and the Coyote Canyon Test Field. These areas are used to conduct violent physics experiments on weapon system components, transport containers, and other assemblies. Test facilities include sled tracks, aerial cables, and drop towers for conducting impact and shock tests. Several burn facilities are located in Lurance Canyon for high heat testing including the Small WInd SHielded (SWISH) facility, the SMoke Emission Reduction Facility (SMERF), and the Open Pool Burn Site Facility (OPOL). Other activities conducted in remote areas include explosive ordnance testing and rocket firing experiments.

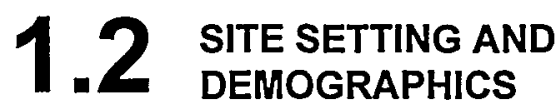

SNL/NM is located in Bernalillo County adjacent to the City of Albuquerque with TA-I facilities the closest point to the city. TA-I is approximately $4 \mathrm{~km}(2.5 \mathrm{mi})$ south of Interstate 40 and approximately $10.5 \mathrm{~km}(6.5 \mathrm{mi})$ east of the downtown area (Figure 1-5).

The KAFB military reservation topography west of the withdrawal boundary is generally flat to gently rolling, being situated on broad alluvial mesas. The exception is Manzano Base, which encompasses a group of hills that have been partially hollowed out for military materials storage. SNL/NM stores radioactive waste in several of these mountain bunkers.

A major topographic feature on the base is the Tijeras Arroyo, which is up to $1,300 \mathrm{~m}$ 


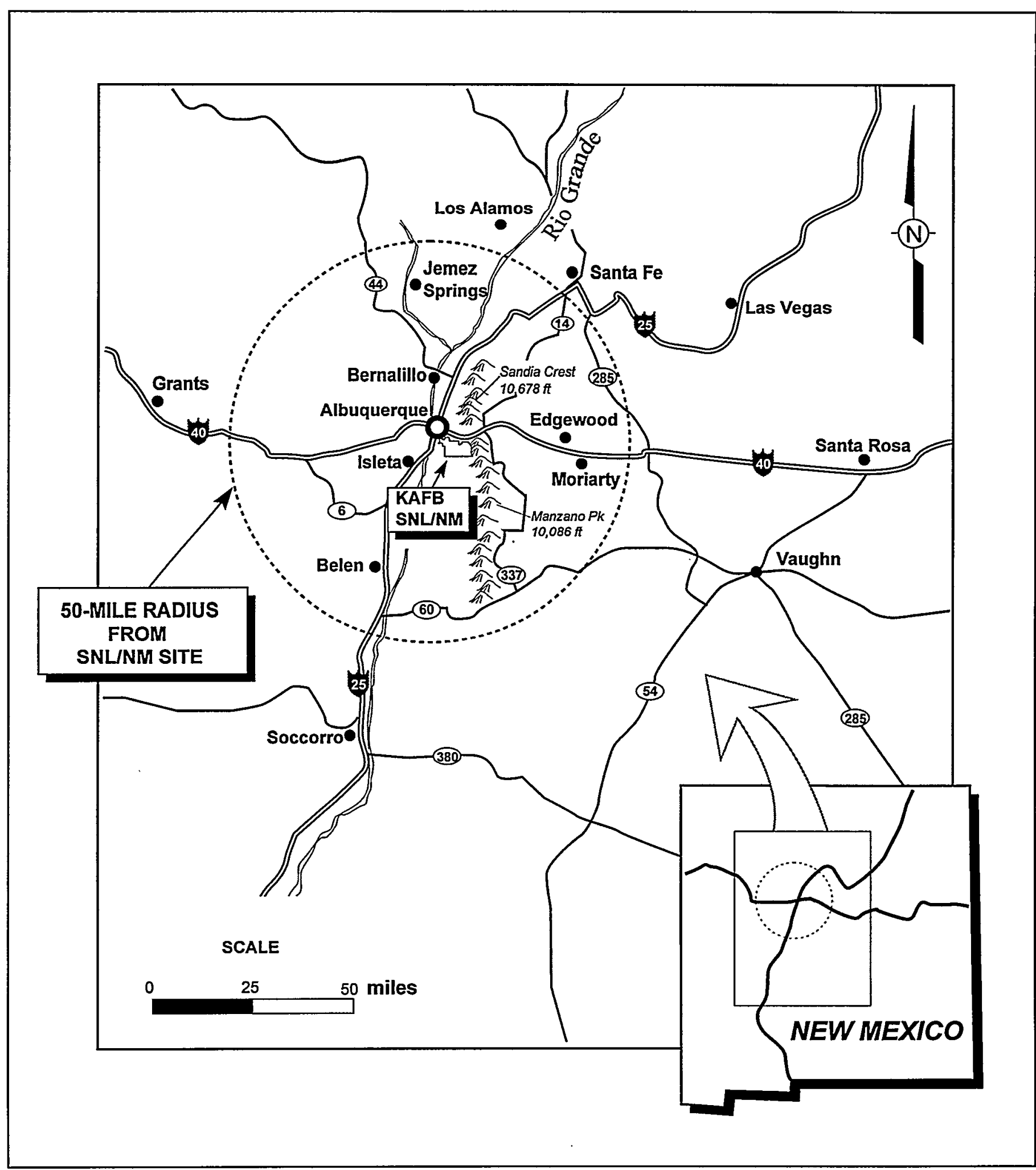


$(4,264 \mathrm{ft})$ wide and $33 \mathrm{~m}$ (108 ft) deep. The Arroyo originates out of Tijeras Canyon trending southwest across KAFB and emptying into the Rio Grande. It drains the southern Sandia Mountains and the north end of the Manzanita and Manzano Mountains. The arroyo is dry except during storm water events. However, because this drainage channel connects to a huge watershed, including storm water runoff from $\mathrm{KAFB}$, its water-carrying capacity is significant.

The land withdrawal on the east side of KAFB contains the western slope of the Manzanita Mountains. This area is topographically characterized by low profile slopes (compared to the sharply eroded cliffs on the west face of the Sandias). The maximum elevation in the Manzanita Mountains on KAFB is $2,434 \mathrm{~m}$ $(7,988 \mathrm{ft})$.

Elevations in the Albuquerque area range from $1,493 \mathrm{~m}(4,900 \mathrm{ft})$ at the Rio Grande (near the intersection of $\mathrm{I}-40$ and $\mathrm{I}-25)$ to approximately $1,767 \mathrm{~m}(5,800 \mathrm{ft})$ at the base of the Sandia Mountains. Sandia Crest is the highest point in the regional area at $3,254 \mathrm{~m}(10,678 \mathrm{ft})$. The KAFB military reservation (excluding the withdrawn area) has a mean elevation of $1,641 \mathrm{~m}$ $(5,384 \mathrm{ft})$.

There are nine counties contained in all or part of a 80-kilometer (50-mile) radius from SNL/NM (Table 1-1). A recent estimate of the population within this radius is 695,406 residents (DOC 1998).

\section{GEOLOGY AND HYDROLOGY}

The regional geologic setting in which SNL/NM and KAFB are situated is on the eastern margin of the Rio Grande rift. This is an area of regional extension where the earth's lithosphere is being pulled apart. The thinning crust has produced normal faulting and recent volcanism allowing mafic magma to extrude in vast sheets.

TABLE 1-1. Counties Within a 50-mile Radius of SNL/NM

\begin{tabular}{|l|l|}
\hline County & Primary Population Centers \\
\hline Bernalillo & $\begin{array}{l}\text { Albuquerque, KAFB, and East } \\
\text { Mountain residents (Sandia and } \\
\text { Manzano Mountains areas) }\end{array}$ \\
\hline Sandoval & $\begin{array}{l}\text { Corrales, Rio Rancho, Bernalillo, and } \\
\text { several Indian Pueblos }\end{array}$ \\
\hline Valencia & Bosque Farms, Los Lunas, and Belen \\
\hline Santa Fe & Edgewood and suburbs of Santa Fe \\
\hline Torrance & $\begin{array}{l}\text { Moriarty and small villages east of the } \\
\text { Manzano Mountains }\end{array}$ \\
\hline McKinley & $\begin{array}{l}\text { Sparsely populated northwest edge of } \\
\text { county }\end{array}$ \\
\hline San Miguel & $\begin{array}{l}\text { Sparsely populated southwest edge of } \\
\text { county }\end{array}$ \\
\hline Cibola & Laguna Pueblo \\
\hline Socorro & $\begin{array}{l}\text { Several small villages on the north } \\
\text { edge of county }\end{array}$ \\
\hline
\end{tabular}

The rift is adjacent to the Colorado Plateau, an area of relatively undeformed flat-lying formations spanning across Arizona, Utah, Colorado, and New Mexico. West of the plateau, is the Basin and Range province stretching from California through Nevada and parts of Utah. It is thought that the Rio Grande rift is a part of the Basin and Range deformational event (NMGS 1984). Similar to the Basin and Range, the rift is characterized by large crustal blocks separated by steeply dipping normal faults. The Rio Grande rift, however, is much broader and deeper than the grabens of the Basin and Range. It is made up of a series of distinct basins extending from Colorado to Mexico. These down dropped basins have filled with great volumes of sediments as they continue to subside.

\section{The Albuquerque Basin}

The Albuquerque basin is one of a series of north-south trending basins that make up the Rio Grande rift zone. This major structural feature of the central Rio Grande rift is approximately $48 \mathrm{~km}(30 \mathrm{mi})$ wide and $161 \mathrm{~km}$ (100 mi) long (Grant 1982) (Figure 1-6). The 


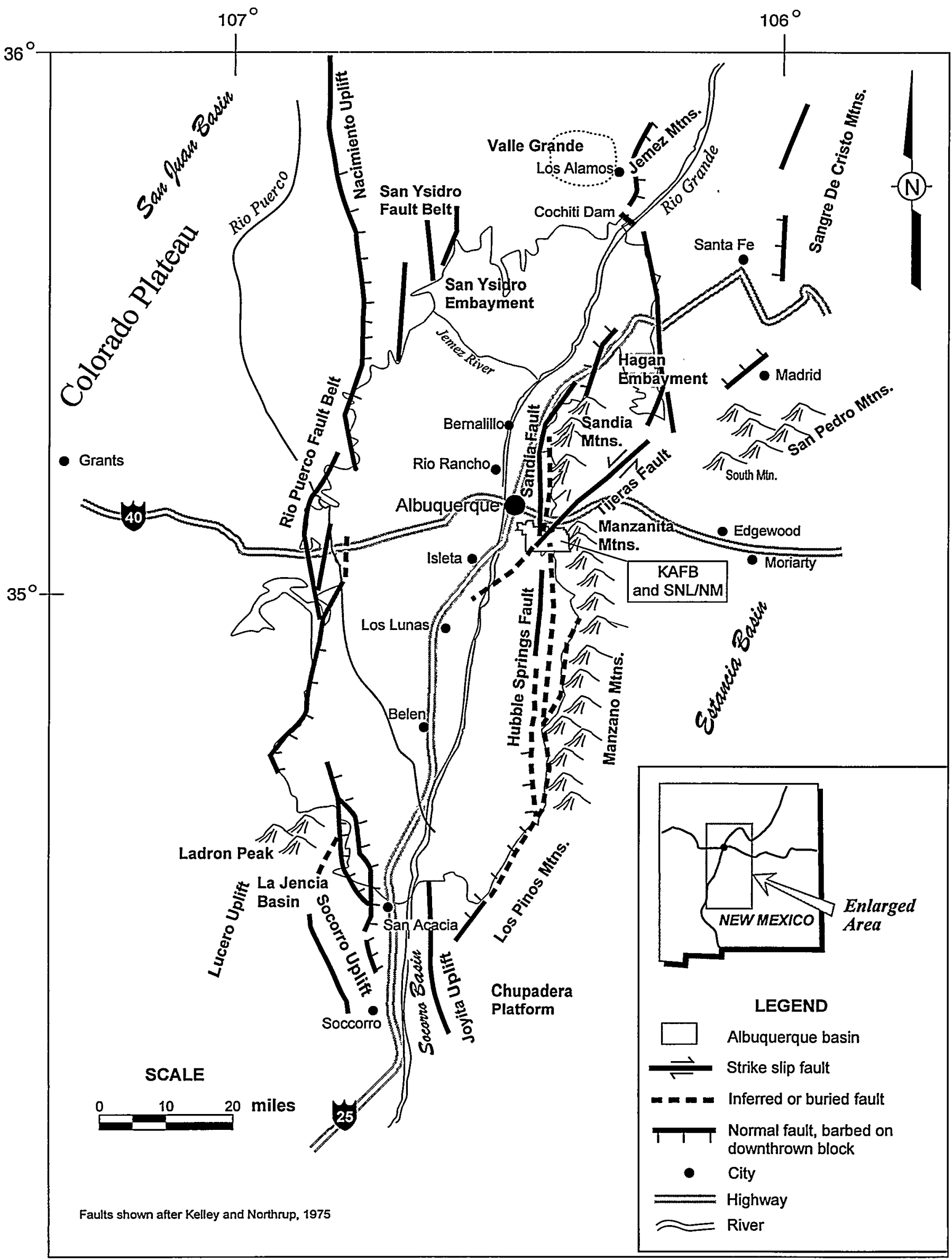


Rio Grande enters the basin from the north and flows southward roughly bisecting the trough, which has an approximate area of $3,000 \mathrm{sq} \mathrm{mi}$. On the east, the basin is bounded by uplifted fault blocks, which are reflected in the Sandia, Manzanita, and Manzano Mountains. The Sandia Mountains form an impressive $21-\mathrm{km}$ (13-mile) long steep escarpment on the east side of the basin. The western side of the basin is bounded by the Lucero uplift to the south, the Rio Puerco fault belt, and the Nacimiento uplift at the northern end. There is relatively little topographic relief along the Rio Puerco fault belt on the northwestern side of the basin.

During the Miocene and Pliocene epochs, the basin filled with as much as $4,560 \mathrm{~m}(15,000 \mathrm{ft})$ of sediments derived from the erosion of the surrounding highlands and material transported into the basin by the ancestral Rio Grande from sources to the north. This sequence of unconsolidated sediments (primarily the Santa Fe Group) thins toward the edge of the basin and is truncated by normal faults at the bounding uplifts.

The Santa Fe Group is overlain in places by Pliocene Ortiz gravel and Rio Grande fluvial deposits, which are interbedded with Tertiary and Quaternary basaltic and pyroclastic materials. Basin-fill sediments of the Santa Fe Group consist of channel, debris flow, and floodplain deposits, and include eolian and playa deposits towards the center of the basin (in the lower unit of the Santa Fe Group). Most of the bedding is thought to be lenticular with limited areal extent, although buried channels or debris flows can extend for great distances (miles). These subsurface features are of major importance in controlling the movement of groundwater within the basin.

\section{Fault Systems}

The geology underlying the eastern section of KAFB includes major faulting (Figure 1-7). The east-west trending Tijeras Canyon, which divides the Sandia Mountains from the Manzanita and Manzano Mountains, was formed by preferential erosion along the Tijeras fault. The Tijeras fault is a strike-slip fault of Paleozoic (and younger) age expressed by southwesterly movement of the northern block (left lateral). The fault has been traced at least as far north as Madrid, New Mexico, and trends southwesterly through Tijeras Canyon and along Four Hills just north of KAFB. The system of faults associated with the Tijeras fault is collectively referred to as the Tijeras fault complex, part of which marks a distinct geologic boundary between the mountains and the regional basin. The Sandia fault is most likely the primary frontal fault that forms the eastern border of the Albuquerque Basin at the base of the Sandia and Manzano ranges.

Other faults on KAFB are the Tertiary age Hubbell Springs and Sandia faults. These are north-south trending, down-to-the-west, enechelon normal faults (Lozinsky et al. 1991; Woodward 1982; Kelley and Northrop 1975). The Hubbell Springs fault extends northward from Socorro County, New Mexico, into the southern portion of KAFB. The Hubbell Bench (south of KAFB) is one of the most easily recognizable fault scarps in the basin, with offsets of 5-30 m (15-100 ft) (Machette 1982). The Sandia fault is thought to be the primary boundary between the Sandia Mountains and the Albuquerque basin and shows evidence of Quaternary motion (Kelley 1977). The Tijeras, Sandia, and Hubbell Springs faults converge in the vicinity of the Chemical Waste Landfill (CWL) in Technical Area III (TA-III).

\section{Regional Geologic History}

The Precambrian granite, gneiss, schist, quartzite, and greenstone exposed in the Sandia Mountains today represent the mountain roots of an ancient system formed 1.5 billion years ago (Kelly 1977). Over the eons, this ancestral Sandia range was eroded to a broad level peneplain forming the Great Unconformity that marks the stratigraphic bottom of all sedimentary rocks in the region.

Beginning about 500 million years ago and continuing through the Cretaceous, the entire 


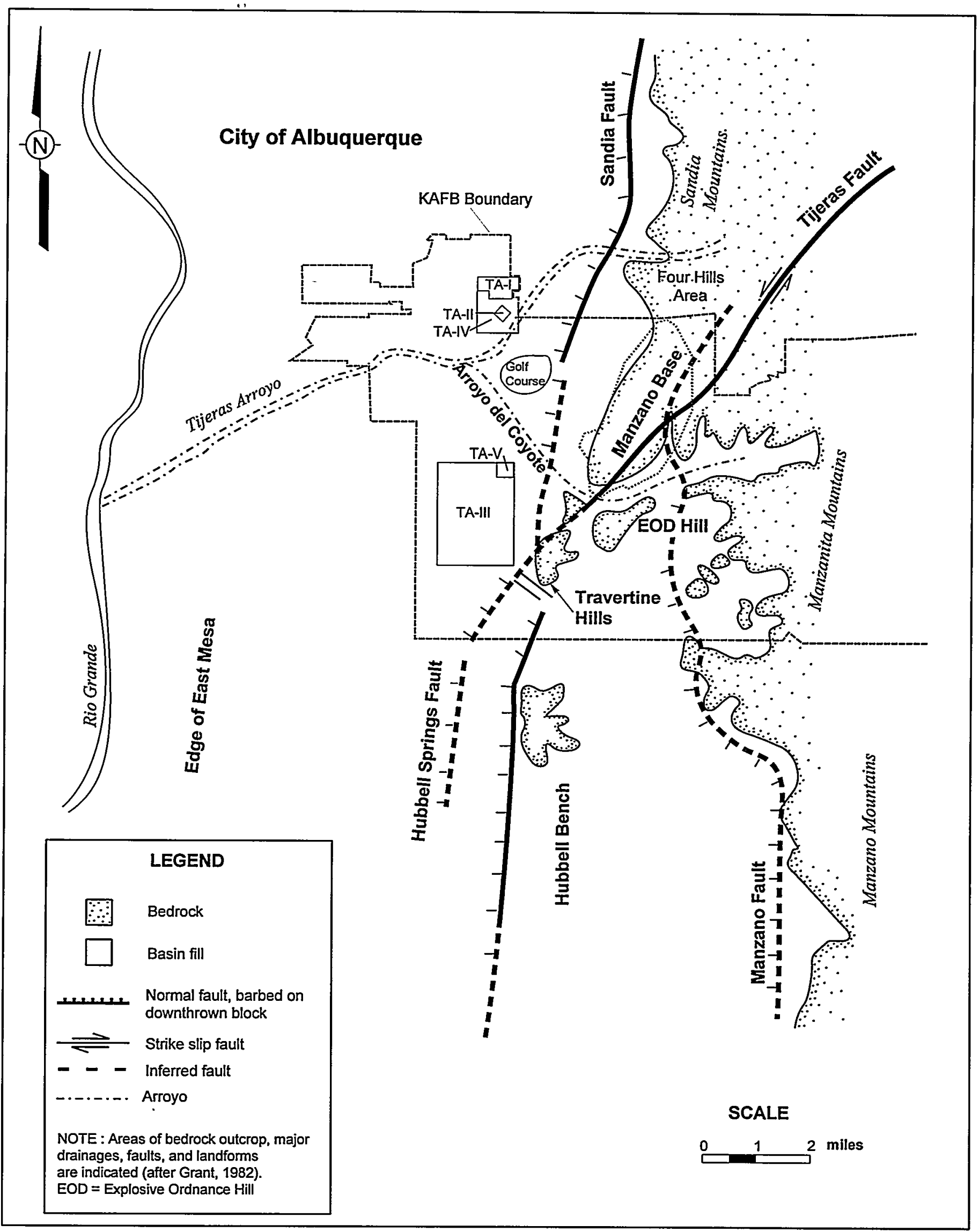


regional area (most of New Mexico and west Texas) was inundated by episodic shallow seas, which laid down great a thickness of marine limestone, sandstone, and shale. The Pennsylvanian Sandia Formation and Madera Group is the bedded limestone, which can be seen capping the top of the Precambrian granite in the Sandia Mountains. However, most of the earlier Paleozoic section is missing, from the regional area; this was either a time of nondeposition or previously deposited beds were eroded. Significant terrestrial deposits are represented between marine inundations. At the close of the Paleozoic, the red beds (from oxidized iron minerals) of the Abo Formation were deposited in a vast flood-plain valley.

By mid-Jurassic (170 million years ago), the seas retreated again and the Entrada Sandstone was deposited in sand dunes covering the Mancos Shale. By late-Jurassic, the climate became wetter and vast lakes and floodplains covered the area depositing the Morrison Formation; dinosaurs flourished during this period as indicated by numerous fossils excavated from this formation. During the Cretaceous, the seas returned and regional subsidence accelerated resulting in huge thicknesses of sandstone and shale forming a deposit nearly as great as the combined thickness of all the sedimentary rocks below it. At the close of Mesozoic era (65 million years ago) the seas retreated for the last time.

By mid-Tertiary (25 to 40 million years ago), the Albuquerque regional area became tectonically active. Volcanoes formed such as Mt. Taylor near Grants and Valley Grande near Los Alamos. Valley Grande is a 22-mile wide caldera - the centerpiece of the Jemez volcanic field. Approximately 2,000 cubic kilometers $\left(\mathrm{km}^{3}\right)$ of material were ejected from this area over several million years of activity that began in the Miocene (Wood and Kienle 1990). Tectonic activity was followed by tremendous faulting and uplift, and marked the beginning of the mountain building era that formed the current Sandia, Manzanita, and Manzano Mountains. These mountain ranges are the result of an east-tilted fault block with the west face uplifted along a steep normal fault. The majority of the uplift occurred during the last 5 to 10 million years. Uplift continues today.

The Albuquerque basin represents an enormous offset in vertical displacement. The equivalent stratigraphic sequence that is exposed on the crest of the mountains today (limestone cap) is located about $8 \mathrm{~km}(5 \mathrm{mi})$ down at the bottom of the basin.

In recent geologic time (less than one million years ago) a small string of 18 volcanoes formed along the western fissure of the Rio Grande trough (Albuquerque Volcanoes). Basaltic lava, extruded from deep within the earth's crust, spread in large sheets over the western Rio Grande Valley. The uneroded remains of this volcanic field are exposed in the low profile cliffs along the west mesa and comprise the rocks of the Petroglyph National Park.

\section{The Rio Grande}

The Rio Grande originates in the Rocky Mountains of southern Colorado and flows approximately $2,896 \mathrm{~km}(1,800 \mathrm{mi})$ to the Gulf of Mexico. This great river has been responsible for much of the landscape created in the region. It supports a narrow but dense swath of Bosque (forested area) along its banks and has left a legacy of past flooding. Flood control has since been managed by the construction of the Cochiti Dam and an extensive system of flood control ditches built by the U.S. Corps of Engineers (ACE 1979). Today, water from the Rio Grande is primarily used for agricultural irrigation. However, plans are being developed to use treated river water to supplement Albuquerque's drinking water supply, which currently is derived solely from deep groundwater wells.

\section{Local Hydrogeologic Setting}

The SNL/NM site is located in a structurally complex terrain with a number of major regional faults intersecting the area. In the vicinity of KAFB, the Tijeras fault complex provides a distinct structural boundary relative to 
subsurface characteristics. To the east of this fault zone complex, the rocks are characterized by fractured and faulted bedrock with a thin alluvium cover and shallow groundwater (50$100 \mathrm{ft}$ below the surface). On the west side of the fault complex-where most SNL/NM facilities are located-the groundwater ranges from $90 \mathrm{~m}$ to $150 \mathrm{~m}$ ( $300 \mathrm{ft}$ to $500 \mathrm{ft}$ ) below the surface. The vadose (or unsaturated zone) in the KAFB area represents an important feature of the hydrologic system. As in most semi-arid climates the thickness of this zone is quite large, resulting in a significant distance that any surface contaminants must travel before reaching the groundwater system.

The primary water-yielding zones are within the upper unit and, to a lesser degree, the middle unit of the Santa Fe Group. Most of the City of Albuquerque's (COA's) water supply wells are located on the east side of the Rio Grande and west of the eastern extent of the ancestral river channel deposits. The highest yield wells are screened in the sediments associated with the ancestral river channel.

Prior to extensive urban development beginning in the 1950s, the direction of groundwater flow was primarily to the southwest in the vicinity of Albuquerque and KAFB. However, as a result of pumping, the water table in the regional Santa Fe Group aquifer has dropped by as much as 43 m (140 ft) (Thorn 1993). Relative to KAFB, groundwater currently flows north-northwest dipping towards the COA well fields.

Two perennial springs, Coyote Springs and Sol se Mete Spring, are present on KAFB. Hubbell Spring, also perennial, is located immediately south of the KAFB boundary on Isleta Indian lands.

\subsection{Eecolocich}

The SNL/NM site vicinity is located at the junction of four major North American physiographic and biotic provinces: the Great Basin, the Rocky Mountains, the Great Plains, and the Chihuahuan Desert. The biotic communities, or biomes, within SNL/NM and KAFB exhibit influences from each of these provinces, with the Great Basin influence generally dominating.

The semi-desert southwest climate produces low surface water availability, resulting in many species of drought-resistant flora such as cacti, yucca, grama grasses, and various desert shrubs. The photo in figure 1-8 illustrates a typical collection of mesa vegetation found on the open spaces of KAFB. Russian thistle (tumbleweed) a non-native plant-proliferates in mechanically disturbed areas. Figure 1-9, taken in the foothills of the Manzanita Mountains, illustrates typical vegetation growing in the canyons and foothills of KAFB. Plants such as junipers (cedars), pinion, live oak, yucca, cholla, grama grass, ring muhly, galleta, and prickly pear cactus predominate. Ponderosa pines mark the transition zone at approximately $1,981 \mathrm{~m}(6,500 \mathrm{ft})$ and are present on the land withdrawal area in mountainous terrain.

Several miles to the west, along the Bosque area of the Rio Grande, cottonwoods, saltbrush, and salt cedar are common plant species.

Mammals, Reptiles, Fish, Amphibians, and Birds

Wildlife that is predominant on most areas of KAFB is typical of species found in grassy woodlands throughout central New Mexico. Typical wildlife groups include rabbits, small rodents, skunks, deer, coyotes, snakes, lizards, and various amphibians. The wooded mountain areas are also home to black bears, mountain lions, bobcats, and foxes. 


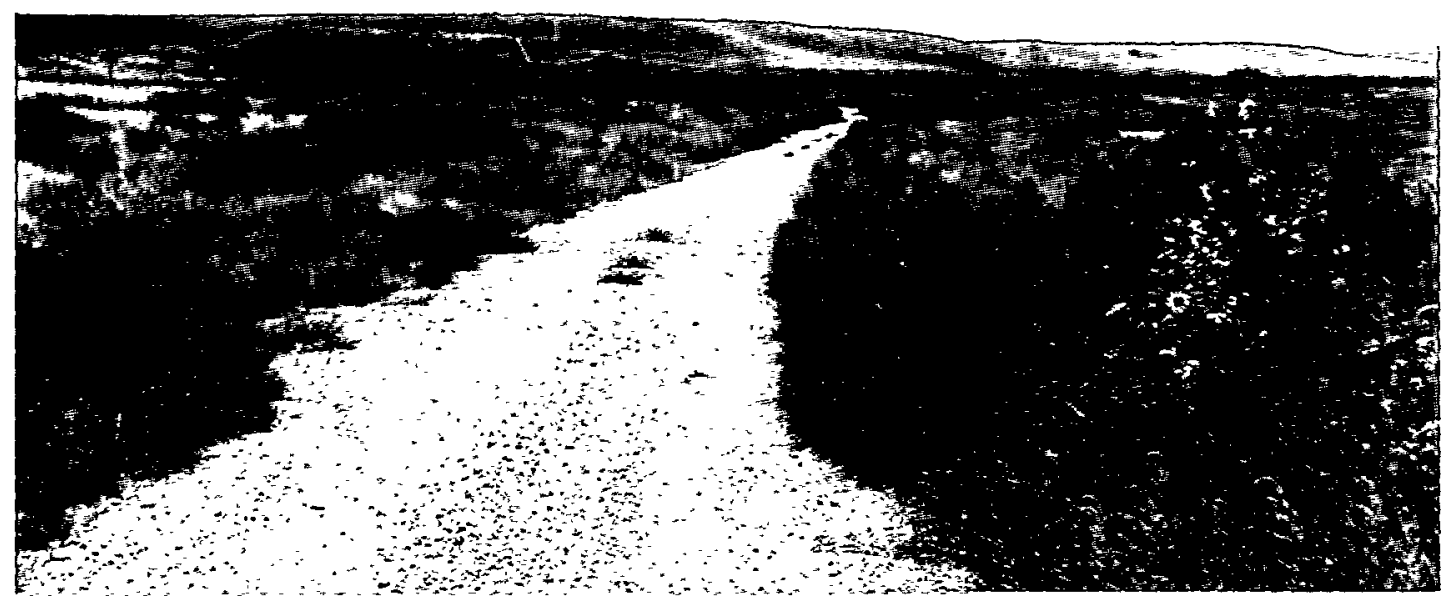

FIGURE 1-8. Typical Vegetation Found in the Open Areas of KAFB West of the Land Withdrawal Boundary

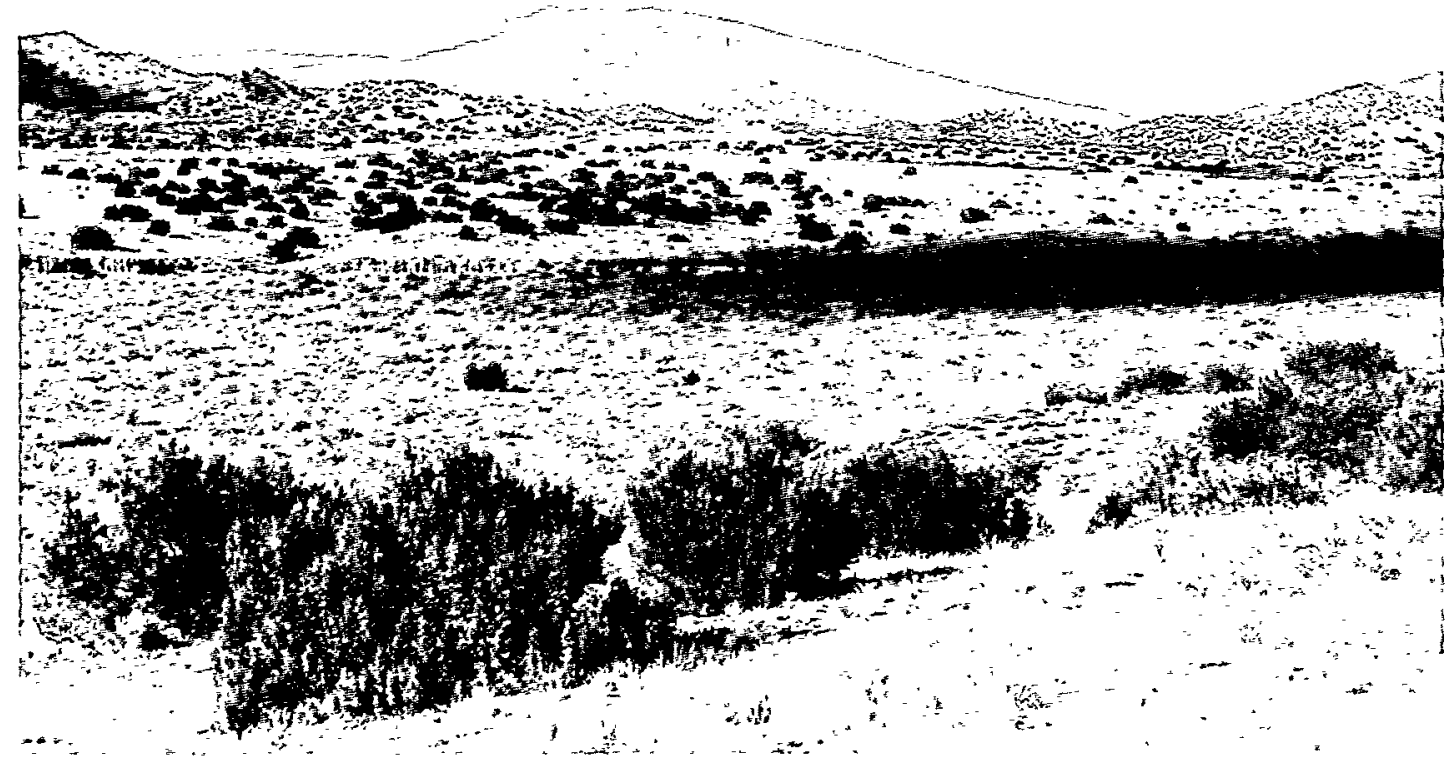

FIGURE 1-9. Typical Vegetation Found in the Higher Elevations and Foothill Areas of KAFB East of the Land Withdrawal Boundary 
Wild animals inhabiting the Rio Grande areas include beavers, muskrats, raccoons, coyotes, skunks, rabbits, and various reptile and amphibian species. The river itself supports stocked trout and the endangered silver minnow.

Migratory birds are abundant and diverse in the KAFB area, as both the Sandia and Manzano Mountains and the Rio Grande represent major flyways. The mountain flyways host migratory birds such as hawks, falcons, eagles, and owls. Other birds common to the area include doves, blue jays, stellar jays, towhees, woodpeckers, chickadees, and hummingbirds. Along the river flyway, migratory birds consist mostly of cranes, geese, and ducks. Other birds common in the lower elevations include hummingbirds, cow birds, meadowlarks, red-winged black birds, pigeons, and ravens.

The most sensitive habitat on KAFB is the wetlands in the vicinity of springs. Although these areas are very minor in extent, they represent an important habitat microcosm, as well as providing an important source of drinking water for wildlife in the area.

\subsection{REgIONAL}

The climate of the Albuquerque Basin is characterized by wide diurnal temperature extremes, seasonal brief heavy rain showers, and frequent drying winds. Air temperatures are characteristic of high-altitude, dry continental climates. Winter daytime high temperatures average 9.6 degrees Celsius $\left({ }^{\circ} \mathrm{C}\right)$ (49.2 degrees Farenheit $\left[{ }^{\circ} \mathrm{F}\right]$ ), while the lows average $-4.6{ }^{\circ} \mathrm{C}$ $\left(23.7^{\circ} \mathrm{F}\right)$. Summer daytime temperatures average $32.7^{\circ} \mathrm{C}\left(90.8^{\circ} \mathrm{F}\right)$, while daily lows average 16.6 ${ }^{\circ} \mathrm{C}\left(61.8^{\circ} \mathrm{F}\right)$ (NOAA 1994). The monthly average relative humidity varies from a low of 30 percent in early summer to 56 percent in early winter. Annual precipitation, most of which occurs between July and October, averages approximately $21 \mathrm{~cm}$ (8.2 in.). The winter season is typically dry with less than $4.0 \mathrm{~cm}$ ( 1.57 in.) of precipitation recorded. The strongest winds occur in the spring when monthly wind speed averages reach 4.6 meters per second $(\mathrm{m} / \mathrm{s})(15 \mathrm{ft} / \mathrm{s})$.

While the regional climate is described by the atmospheric state variables of temperature and humidity, site-specific meteorology at SNL/NM is influenced by the proximity to topographic features. Topographic features, such as mountains, canyons, and arroyos, influence local wind patterns across the site. Canyons and arroyos tend to channel or funnel wind, whereas mountains create upslope-downslope diurnal (day/night) wind flows. These topographically induced wind flows can be enhanced or negated by synoptic (regional) weather systems that move across the southwest part of the United States.

In addition to the different wind patterns found across SNL/NM, annual precipitation is generally greater than the climatological average in the foothills located on the east of KAFB. Section 5.1 contains a description of SNL/NM's meteorological monitoring program and annual monitoring results. 


\section{Complance Summary}

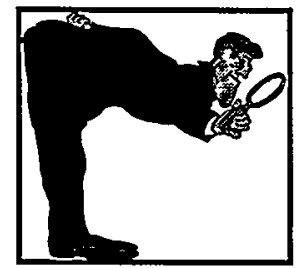

$\mathrm{S}$ NL/NM complies with federal, state, and local environmental laws, regulations, and statutes, and specific rulings contained in Executive Orders (EOs). As a prime contractor to DOE, SNL/NM conducts its operations under the guidance contained in DOE orders. SNL/NM strives to meet 100 percent regulatory compliance standards - both in letter and spiritwith all applicable environmental laws and internal Environment, Safety, and Health (ES\&H) requirements.

This chapter summarizes compliance with the major environmental laws and statutes applicable to SNL/NM operations. A summary of ongoing issues and actions, occurrences, release reporting, permit status, and the results of external audits and assessments are discussed at the end of the chapter. The individual environmental programs responsible for supporting compliance activities are discussed more fully in the remaining chapters.

\section{1 compliance status}

\subsubsection{Comprehensive Environmental Response, Compensation, and Liability Act (CERCLA)}

CERCLA, commonly known as "Superfund," provides cleanup funds and/or assessment requirements for inactive waste sites at all federal facilities. CERCLA requirements are implemented under 40 CFR 302.
A Preliminary Assessment/Site Inspection (PA/SI), as required by the Superfund Amendments and Reauthorization Act (SARA) Section 120 (c), was performed at SNL/NM in 1988. This inspection confirmed that SNL/NM does not own any sites that would qualify for listing on the National Priorities List (NPL). Therefore, with respect to inactive waste sites, SNL/NM has no CERCLA reporting requirements. SNL/NM was in full compliance with CERCLA and SARA in 1997.

Other CERCLA reporting requirements defined under SARA are discussed in the following section.

\subsubsection{Superfund Amendments and Reauthorization Act (SARA) Title III}

The relevant requirements to SNL/NM under SARA, are contained in Title III, also known as the Emergency Planning and Community Rightto-Know Act of 1986 (EPCRA). EPCRA applies to all facilities in which there is present a threshold quantity of extremely hazardous substances (EHSs) equal to or greater than the threshold planning quantities, or in specifically designated amounts as determined by the local community. Additionally, EO 12856, Federal Compliance with Right-to-Know Laws and Pollution Prevention, signed by President Clinton on August 3, 1993, directed all federal agencies to comply with EPCRA.

Reportable Quantities (RQs) are defined as the amount of any extremely hazardous chemical listed in CERCLA or in EPCRA's list of EHSs, in quantities greater than or equal to the stated 
reportable thresholds. There were no reportable releases under EPCRA or CERCLA in 1997.

Table 2-1 lists the specific sections under EPCRA that require reporting. SARA reporting requirements under Section 313 require a Toxic Release Inventory (TRI) report to be submitted annually to the U.S. Environmental Protection Agency (EPA) if chemicals used onsite are above the reporting threshold. In 1997, SNL/NM did not submit a TRI report because chemical use did not exceed the reporting threshold. Supporting documentation detailing chemical purchase and use onsite, however, was published in place of a TRI report (SNL 1998a). SNL was in full compliance with SARA Title III in 1997.

\subsubsection{Resource Conservation and Recovery Act (RCRA)}

RCRA regulates the generation, treatment, storage, and disposal of hazardous chemical waste, non-hazardous solid waste, and hazardous or petroleum products stored in underground storage tanks (USTs).

The Hazardous Waste Program at SNL/NM is under the compliance authority of the New Mexico Environment Department (NMED), which regulates both hazardous waste and the hazardous component in radioactive mixed waste (MW).

TABLE 2-1. SNL/NM Reporting Activities in 1997 with Respect to SARA Title III Compliance

\begin{tabular}{|c|c|c|c|c|c|}
\hline & & \multicolumn{3}{|c|}{ SNL Reporting } & \\
\hline $\begin{array}{l}\text { SARA, } \\
\text { Title III } \\
\text { (EPCRA) }\end{array}$ & $\begin{array}{l}\text { Regulation } \\
\text { Section } \\
\text { Description }\end{array}$ & Yes & No & $\begin{array}{c}\text { Not } \\
\text { Required }\end{array}$ & Explanation \\
\hline $302-303$ & $\begin{array}{l}\text { Planning } \\
\text { Notification }\end{array}$ & $\bar{\checkmark}$ & & & $\begin{array}{l}\text { This report was submitted to notify state and } \\
\text { local emergency response authorities, and to } \\
\text { carry out other facility notification } \\
\text { responsibilities necessary for the development } \\
\text { and implementation of state and local emergency } \\
\text { response plans. }\end{array}$ \\
\hline 304 & $\begin{array}{l}\text { Emergency } \\
\text { Release } \\
\text { Notification }\end{array}$ & & & $\checkmark$ & $\begin{array}{l}\text { No reportable quantity (RQ) releases of an } \\
\text { extremely hazardous substance (EHS), or as } \\
\text { defined under CERCLA, occurred in } 1997 \text {. }\end{array}$ \\
\hline $311-312$ & $\begin{array}{l}\text { Material Safety } \\
\text { Data Sheets } \\
\text { (MSDS) and } \\
\text { Chemical } \\
\text { Inventory }\end{array}$ & $\checkmark$ & & & $\begin{array}{l}\text { Submitted Tier } 1 \text { and } 2 \text { reports in March } 1998 . \\
\text { There are two reporting requirements: (1) an } \\
\text { inventory report listing all hazardous chemicals } \\
\text { (onsite above threshold levels) must be submitted } \\
\text { annually to state and local emergency response } \\
\text { groups and fire departments; (2) all MSDS }{ }^{1} \\
\text { information must be made available to local } \\
\text { emergency organizations. }\end{array}$ \\
\hline 313 & $\begin{array}{l}\text { Toxic Release } \\
\text { Inventory (TRI) } \\
\text { Reporting } \\
\end{array}$ & & & $\bar{\checkmark}$ & $\begin{array}{l}\text { SNL/NM was below the reporting threshold in } \\
1997 \text { and therefore did not submit a TRI report. }\end{array}$ \\
\hline
\end{tabular}

NOTE: 1Material Safety Data Sheets list all relevant chemical information for each chemical used onsite. 
The following bullets describe the status of SNL/NM's compliance with applicable RCRA requirements in 1997.

- Hazardous Waste - Hazardous waste is regulated under RCRA "Subtitle C," implemented by 40 CFR 260-268, 270-272, and 279. SNL/NM's hazardous waste is handled by the Hazardous Waste Management Facility (HWMF) in TA-II. This facility is included on the RCRA Part B Operating Permit as shown on the list for all site permits in table 2-3. The 1997 NMED audit of the facility found one violation regarding a paperwork error that resulted in a small fine (\$780). However, the NMED audit did identify numerous hazardous waste handling violations at generator sites, such as improper labeling and open containers, that resulted in a total fine to the corporation of $\$ 18,000$. There were no releases or occurrences, associated with the HWMF facility in 1997. The HWMF shipped a total of $50,153 \mathrm{~kg}$ of RCRA-hazardous waste in 1997.

- Solid Waste - Non-hazardous solid waste is regulated under RCRA "Subtitle D." The Solid Waste Transfer Facility (SWTF) in TA-II screens, bales, and ships most nonhazardous solid waste generated at SNL/NM. The facility also serves as SNL/NM's central recycling center for paper and cardboard. The SWTF does not accept construction debris, liquids, food service garbage, or hazardous waste. In 1997 , the facility handled $1,091,617 \mathrm{~kg}$ of solid waste and recycled $661,328 \mathrm{~kg}$ of paper, cardboard, and wood pallets. This included $319,624 \mathrm{~kg}$ of recyclables from DOE, Los Alamos National Laboratory (LANL), and KAFB. The facility was in full compliance with all New Mexico Solid Waste Regulations in 1997.

- Environmental Restoration (ER) Sites By the end of fiscal year 1997 (FY97), 146
ER sites remained to be addressed at the SNL/NM site; all are regulated under the RCRA Part B Operating Permit issued by NMED on August 26, 1993. ER sites are being assessed and remediated as required by the Hazardous and Solid Waste Amendments (HSWA) module to RCRA, Section 3004(u) "Continuing Releases at Permitted Facilities." Corrective Actions (CAs) for continuing releases from Solid Waste Management Units (SWMUs)-whether active or inactive-are stipulated in the requirements of the permit. The ER project generated $344,334 \mathrm{~kg}$ of RCRA-hazardous ER waste in 1997. SNL/NM met all RCRA permit conditions for ER sites in 1997.

- Underground Storage Tanks (USTs) USTs are regulated under RCRA "Subtitle I," codified as 40 CFR 280 and 40 CFR 281. SNL/NM also must meet State of New Mexico regulations that are consonant with federal UST standards. In 1997, SNL/NM operated five registered tanks. One of the five tanks was registered after SNL/NM received a Field Notice of Violation. The violation was for failure to register a UST after April 14, 1988, and failure to use release detection. The tank was closed and a Notice of No Further Assessment was completed in August 1997. No fines were incurred. At the end of 1997, four registered USTs remained in service at SNL/NM.

- Mixed Waste (MW) - MW is dually regulated under RCRA and the Atomic Energy Act (AEA) of 1954. In 1997, SNL/NM generated $5,515 \mathrm{~kg}$ of $\mathrm{MW}$; no MW was received from the SNL/CA site in Livermore. There were no shipments of MW offsite in 1997. However, $18.5 \mathrm{~m}^{3}$ of shredded Historical Request Validation Project (HDRV) waste was sent to the Waste Experimental Reduction Facility (WERF) at Idaho National Engineering and Environmental Laboratories (INEEL) in 
February 1998. No further sorting of legacy waste associated with the HDRV Project occurred in 1997 and the project has since been discontinued.

Onsite treatment of newly generated MW began in late summer of 1997 . Of the treatment methods listed on the Part B Permit, two primary treatment methods (deactivation and solidification/ stabilization) were performed at the Radioactive and Mixed Waste Management Facility (RMWMF) in 1997. Currently, all MW is sorted into treatability groups based on Level I, Level II, and Level III sorting. Level III waste groups have the highest radioisotope activities.

- Explosive Waste Disposal - In 1997, $5 \mathrm{~kg}$ of explosive waste was treated at the Thermal Treatment Facility (TTF). Another $126 \mathrm{~kg}$ of explosive waste was treated at the KAFB Explosive Ordnance Disposal (EOD) site.

- Temporary Unit (TU) and Corrective Action Management Unit (CAMU) - The TU/CAMU was designed and constructed to store, treat, and dispose of contaminated ER soils generated from SNL/NM onsite remediation projects. The TU is permitted to store waste for up to one year, extending the usual 90-day allowance at a generator facility. Waste storage at the TU is expected to begin by June 1998. The CAMU will be used to both treat hazardous contaminated soils and to dispose of treated soils onsite. Only soils that have been treated to the required standards will be disposed at the CAMU. TU/CAMU operations are expected to greatly facilitate the completion of all ER waste treatment by the year 2001.

\subsubsection{Federal Facility Compliance Act (FFCAct)}

On October 6, 1992, the FFCAct was passed into law, amending RCRA and addressing DOE's noncompliance with Land Disposal Restrictions (LDRs) for MW. LDRs require the treatment of hazardous waste to reduce the toxicity, volume, and likelihood of migration. Only waste that meets the required LDR standards can be disposed. The FFCAct required $\mathrm{DOE}$ to develop $\mathrm{MW}$ treatment technologies that would meet the LDRs. SNL/NM developed treatment technologies in 1997, and in February 1998 the first shipment of MW was sent to INEEL for treatment. A detailed description of the history leading up to the first offsite shipment of $\mathrm{MW}$ is given in section 3.2.3.

\subsubsection{National Environmental Policy Act (NEPA)}

NEPA was passed by the U.S. Congress in 1969 to articulate a new national policy with regard to protection of the environment. NEPA also established the Council on Environmental Quality (CEQ) to establish rules and regulations for implementing the new policy. NEPA and regulations promulgated by the $\mathrm{CEQ}$ require federal agencies to analyze more than one alternative course of action, including a "no action" alternative, whenever the federal government proposes an action that could have environmental impacts. For actions that are deemed likely to result in significant environmental impacts, an Environmental Assessment (EA) or an Environmental Impact Statement (EIS) must be prepared.

SNL/NM's NEPA Program, under the direction of DOE/Kirtland Area Office (DOE/KAO), provides technical guidance for comprehensive compliance with NEPA and associated acts including cultural resources acts, the Endangered Species Act (ESA), and other related resource protection laws. 
1997 NEPA Documentation

During 1997, SNL/NM submitted 95 NEPA Environmental Checklists/Action Description Memorandums (ECL/ADMs) to DOE/KAO for determination on proposed projects or actions.

$\mathrm{DOE} / \mathrm{KAO}$ determines if the proposed actions fall under a Categorical Exclusion, are already part of an existing EA or EIS, or require further NEPA documentation. All 95 ECL/ADMs required no further NEPA action.

NEPA compliance activities during 1997 included the completion of two EAs that each resulted in a Finding of No Significant Impact (FONSI). Input continued on the Site-Wide Environmental Impact Statement (SWEIS) being prepared for SNL/NM facilities. The completed NEPA documents are as follows:

- Environmental Assessment for the Atmospheric Radiation Measurement (ARM) Program, North Slope of Alaska and Adjacent Arctic Ocean Cloud and Radiation Test Bed, DOE/EA-1193. FONSI issued February 27, 1997) (DOE 1997a).

- Environmental Assessment of the Sandia National Laboratories Design, Evaluation, and Test Technology Center at Technical Area III, Kirtland Air Force Base, New Mexico, DOE/EA-1195. (FONSI issued April 18, 1997) (DOE 1997b).

\subsubsection{Clean Air Act (CAA) and CAA Amendments (CAAA) of 1990}

The objectives of the CAA and the CAAA are to protect and enhance the quality of the nation's air and thereby protect public health and the environment. The U.S. Environmental Protection Agency (EPA) is responsible for describing and regulating air pollutants from stationary and mobile sources, as well as setting ambient air quality standards. The City of Albuquerque (COA) locally administers these standards as well as specific air emission permits as shown in table 2-3.

\section{Ambient Air Quality}

The COA announces air quality alerts and posts them along major thoroughfares requesting voluntary or mandatory compliance. Yellow alerts request voluntary cooperation to limit driving and burning. Red alerts are mandatory "No-Burn Periods," and request voluntary nodrive cooperation. SNL/NM honors these notices by not performing any open burns or detonations during yellow or red alerts. The COA had 100 percent compliance in 1997, noting no recorded exceedences in the local ambient air quality standards. The COA publishes a pollution index listing criteria pollutants and local pollen counts in the Albuquerque Journal.

There were no exceedences recorded in ambient air quality standards at any of SNL/NM's six ambient air monitoring stations in 1997.

National Emission Standards for Hazardous Air Pollutants (NESHAP), Subpart H, Radionuclide Air Emissions

SNL/NM was in full compliance with NESHAP air quality requirements in 1997.

The EPA designates radionuclides as a hazardous air pollutant (HAP). As required by 40 CFR 61, Subpart H, a dose assessment was performed to evaluate radioactive air emissions with respect to exposed members of the public. The maximally exposed individual (MEI) for 1997 was' again located at the Kirtland Underground Munitions Storage Complex (KUMSC). The dose received at this location was 0.00077 millirem/year (mrem/yr) $(0.0000077$ millisievert/year $[\mathrm{mSv} / \mathrm{yr}])$. This is approximately 100,000 times less than EPA's maximum allowable dose of $10 \mathrm{mrem} /$ year. The population dose to all members of the public within a 80-kilometer (50-mile) radius was 0.023 person-rem/yr (0.00023 person Sv/yr). 


\section{Hazardous Chemical Inventory}

As required by Title III of the CAA (implemented by 40 CFR 70-71 and 20 NMAC 11.42) and SARA Title III Toxic Release Inventory (TRI) reporting requirements (Section 313), a hazardous chemical purchase inventory is conducted annually to determine SNL/NM's hazardous chemical use onsite. Reports are created from (1) Material Safety Data Sheets (MSDSs), which are made available for all chemicals used onsite, and (2) an inventory of purchased chemicals. Although a TRI report was not required in 1997 because chemical use was under the reporting threshold, a hazardous chemical inventory report was published that described SNL/NM's chemical use and inventory in 1997 (SNL 1998a).

Table 2-2 presents the results of the 1997 hazardous chemical inventory. The table includes chemicals from the SARA Toxic Chemical List.

\subsubsection{Clean Water Act (CWA)}

The CWA sets forth goals to protect U.S. waters by controlling discharged pollutants. As it pertains to SNL/NM, the CWA applies to sanitary and septic system wastewater effluents, storm water runoff, and surface water discharges. The CWA is implemented through federal, state, and local water quality standards. The COA administers sanitary sewer discharges based on federal pretreatment standards, the NMED administers regulations concerning surface discharges, and the EPA retains oversight of storm water discharges and provides requirements for the Oil Spill Prevention Control and Countermeasures (SPCC) Plan for Sandia National Laboratories, New Mexico (CDM 1995).

\section{COA Sewer Discharge Regulations}

There are six wastewater monitoring stations at SNL/NM. Four of these discharge directly to the publicly-owned sewer subject to the city's Sewer Use and Wastewater Control Ordinance.
There were three instances of $\mathrm{pH}$ excursions above the permitted values in 1997. These are discussed in section 2.5 and section 6.1.5.

\section{National Pollutant Discharge Elimination System (NPDES)}

NPDES implements CWA requirements specific to discharges to waters of the United States as defined in the CWA. At SNL/NM, this is applicable to storm water runoff. SNL/NM received a Multi-sector General Permit in August 1997 after six years of operating under a pending permit application. The initial permit application was submitted to the EPA in 1992 and was never acted on. Because SNL/NM was operating under a pending permit in 1997, no storm water monitoring took place during the first half of the year, although sampling was performed in July before the permit was issued. Two metals were found to exceed the pending permit limits: zinc and iron. However, these results are inconclusive since they represent only one data point and results are inconsistent with previous sampling events. Regardless, this indicates a potential problem that SNL/NM will investigate if future samples also show high values.

A State Pollutant Discharge Elimination System (SPDES) permit, required in some states, is not required in New Mexico.

\section{Surface Water Discharge}

Surface discharges are evaluated for compliance with regulations implemented through the New Mexico Water Quality Control Commission (NMWQCC). Two surface discharge lagoons require permitting at SNL/NM; all permit conditions for these lagoons were met for 1997.

In 1997, there were three occurrences categorized as surface discharge violations. (Other discharges to the surface were categorized under waste management violations.) Occurrences are discussed in section 2.5 . 
TABLE 2-2. 1997 Summary of SNL/NM's Chemical Purchases in Quantities Greater than $1,000 \mathrm{lb}$

\begin{tabular}{|c|c|c|}
\hline Chemical & $\begin{array}{c}\text { Chemical Abstract } \\
\text { System (CAS) Number }\end{array}$ & Usage (lb/year) \\
\hline Acetone & $67-64-1$ & 6,405 \\
\hline Ammonium fluoride & $12125-01-8$ & 2,541 \\
\hline Ethanol & $64-17-5$ & 2,689 \\
\hline Propylene carbonate & $108-32-7$ & 1,376 \\
\hline Methoxy acetate & $108-65-6$ & 2,211 \\
\hline 2-(2-ethoxyetoxy) ethanol & $111-90-0$ & 1,959 \\
\hline Carbon dioxide & $124-38-9$ & 10,125 \\
\hline Thiophene, tetrahydro. 1,1,-dioxide & $126-33-0$ & 3,112 \\
\hline Sodium hydroxide & $\overline{1310-73-2}$ & 125,496 \\
\hline Sulfur hexaflouride & $2551-62-4$ & 14,030 \\
\hline Argon & $7440-37-1$ & 128,406 \\
\hline Hydrogen peroxide & $7722-84-1$ & 2,861 \\
\hline Nitrogen & $7727-37-9$ & $5,021,732,028$ \\
\hline Oxygen & $7782-44-7$ & $20,211,185$ \\
\hline Kerosene & $800-20-6$ & 63,417 \\
\hline Nitrous oxide & $10024-97-2$ & 2,009 \\
\hline Methanol & $67-56-1$ & 2,461 \\
\hline Isopropyl alcohol & $67-63-0$ & 4,566 \\
\hline Polyethylene oxide & $25322-68-3$ & 1,145 \\
\hline Mineral oil & $64742-65-0$ & 1,097 \\
\hline Perflouro compounds & $86508-42-1$ & 3,127 \\
\hline Napthalene & $91-20-3$ & 1,001 \\
\hline Ethylene glycol & $107-21-1$ & 2,493 \\
\hline Tetrachloroethylene & $127-18-4$ & 1,819 \\
\hline N-Methyl-2-pyrrolidone & $872-50-4$ & 3,897 \\
\hline Hydrogen chloride & $7647-01-0$ & 55,309 \\
\hline Phosphoric acid & $7664-38-2$ & 1,542 \\
\hline Sulfuric acid & $7664-93-9$ & 24,589 \\
\hline Nitric acid & $7697-37-2$ & 5,117 \\
\hline TOTAL & & $5,042,681,184$ \\
\hline
\end{tabular}




\subsubsection{Safe Drinking Water Act (SDWA)}

SDWA, which has set National Primary Drinking Water Standards, is designed to protect human health by regulating the discharge of nontoxic and toxic pollutants into both groundwater and surface water sources from residential, municipal, and industrial discharges. KAFB provides the majority of potable water used by SNL/NM from its production wells and, therefore, is responsible for compliance with the National Primary Drinking Water Standards. KAFB samples for trihalomethanes, coliforms, volatile organic compounds (VOCs), gross alpha and gross beta radioactivity, and other specifically listed inorganic chemicals.

There are several remote water delivery systems at SNL/NM used to supply water to the test areas in Coyote Canyon and the 6000 Igloo Complex. This system has been classified as a Non-Transient, Non-Community (NTNC) water system. The NMED has approved the SNL/NM sampling plan for this NTNC system. SNL/NM samples for coliform, lead, and copper determinations.

\subsubsection{Toxic Substances Control Act (TSCA)}

At SNL/NM, compliance with the TSCA primarily involves the handling and disposal of polychlorinated biphenyls (PCBs) and asbestos waste. TSCA also addresses the import and export of specifically listed chemicals. All TSCA waste and recyclables are handled and shipped by the Hazardous Waste Management Facility (HWMF). In 1997, the HWMF received 28,591 $\mathrm{kg}$ of PCB waste and $155,951 \mathrm{~kg}$ of asbestos waste. All wastes were disposed of or recycled at permitted offsite facilities. There were no instances of non-compliance with TSCA regulations in 1997.

\subsubsection{Federal Insecticide, Fungicide, and Rodenticide Act (FIFRA)}

Compliance to the FIFRA is overseen by SNL/NM's Pest Control Activity. Most FIFRAregulated chemicals used at SNL/NM are herbicides for weed control. To a lesser extent, there is a need to control rodents and insects. Annual pesticide use is reported to the KAFB Civil Engineering Department. All chemicals used are EPA-approved and applied with EPAapproved applicators. There were no instances of noncompliance with FIFRA in 1997.

\subsubsection{Endangered Species Act (ESA)}

The ESA applies to both private individuals and federal agencies. At SNL/NM, ESA is addressed by the NEPA program. Section 9 of the ESA makes it illegal for any person to "take" any endangered species of fish or wildlife. "Take" means to harass, harm, pursue, shoot, hurt, kill, capture, or collect, and includes interfering with habitat. Section 7 of ESA applies only to federal agencies, which must ensure that any action authorized, funded, or carried out by them will not jeopardize the continued existence of a threatened or endangered species, or result in adverse modifications of its habitat.

The term "sensitive species" has a much broader connotation for NEPA compliance purposes than "threatened or endangered." It includes federally-listed and state-listed threatened or endangered species, candidate species for listing, species listed by other federal agencies, species protected under other laws and regulations, and species perceived by the public as "sensitive."

Prior to beginning any proposed action that may potentially affect sensitive species or habitats, SNL/NM must prepare an ECL/ADM and submit it to DOE for a determination. Furthermore, DOE must confer with the following agencies: (1) the U.S. Fish and 
Wildlife Service, (2) the New Mexico Game and Fish Department, and/or (3) the New Mexico Energy, Minerals, and Natural Resources Department. The U.S. Forest Service may also be contacted if the project is to be conducted within the land withdrawal area on the east side of KAFB. If potentially significant impacts to sensitive species or habitat may result from the proposed action, an EA or EIS shall be prepared. Of the federally-listed threatened, endangered, and sensitive species that have the potential to occur on KAFB (including withdrawn portions), only the peregrine falcon (Falco periginus) also a state-listed Endangered Group 1 species-has been observed on KAFB. However, no nesting activity of this species has been observed and only marginal habitat exists for nesting.

No plant species that are currently listed as endangered by the New Mexico Forestry and Resource Conservation Division are known to occur on KAFB and only one sensitive (List 2) plant species, the Santa $\mathrm{Fe}$ milkvetch (Astragalus feensis), has been recorded.

The SNL/NM Environmental Baseline Update (SNL 1996a) includes a section on biological resources. The management of sensitive species areas is also discussed in the ES\&H Manual (SNL 1997j).

\subsubsection{Cultural Resources Acts}

Cultural resources management at SNL/NM is required under acts such as the following:

- National Historic Preservation Act (NHPA)

- Archaeological Resources Protection Act (ARPA)

- American Indian Religious Freedom Act (AIRFA)

SNL/NM integrates cultural resources management into the NEPA program. The SNL/NM Environmental Baseline Update (SNL 1996a) provided information on the affected environment that must be addressed in the NEPA process. It is DOE policy that NEPA review must be performed for all DOE actions potentially affecting the environment; thus, even actions that are classified as Categorical Exclusions are reviewed for impacts on cultural resources.

Historical properties (as defined by NHPA and implementing regulations) include archeological sites and historic buildings and structures. SNL/NM activities are usually planned to avoid potential impact to such sites. There are no known archeological sites located on USAF and U.S. Forest Service withdrawn lands used by SNL/NM. Historic buildings and structures may include those dating from the World War II and Cold War eras. SNL and DOE have begun assessments of potentially historic buildings and structures from these periods.

As with sensitive species compliance, locations that could adversely affect cultural resources are initially analyzed in an ECL/ADM document. Cultural resource compliance is discussed in the ES\&H Manual (SNL 1997j).

\subsubsection{Executive Orders (EOs)}

Two EOs germane to NEPA compliance are EO 11988, Floodplain Management and EO 11990, Protection of Wetlands.

EO 11988 has minimal impact for SNL/NM. All active SNL/NM facilities are located outside the 500-year floodplain as described by the U.S. Army Corps of Engineers for both arroyos (ACE 1979). The SNL/NM boundary of the 100-year flood plain does occur along the arroyo boundaries as described in the SNL/NM Environmental Baseline Update (SNL 1996a).

EO 11990 relates to the preservation of wetlands and has some relevance to KAFB. Although, extremely limited in area, there are areas on KAFB in the vicinity of natural springs that can be considered wetlands. These areas are 
managed with care to preserve an important source of drinking water for wildlife as well as to preserve the biological niche created by the presence of water in an otherwise arid habitat.

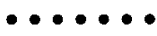

\section{SUMMARY OF ENVIRONMENTAL PERMITS}

SNL/NM holds-or has submitted application for-all applicable environmental permits. Table 2-3 lists all environmental permits and registrations that were in effect in 1997 including permits that are pending and under review by various agencies.

\subsection{CURRENT COMPLIANCE
ISSUES AND ACTIONS}

Environmentally-related issues and actions of concern or interest to SNL/NM for 1997 are discussed below.

- 20 NMAC 11.02, Permit Fees - Since 1994, when Title V of the CAAA became effective, SNL/NM has been paying a per ton emission fee based on its annual maximum potential to emit air emissions (a much higher estimate than actual operating conditions). With the proposed Title V permit application (\#515) still under review, SNL/NM realized a substantial savings by implementing an annual emissions inventory that is based on fuel throughput. By doing this SNL/NM pays fees calculated on a volume of actual fuel used. However in 1997 , the COA raised the fee from $\$ 20.89$ to $\$ 31.00$ per ton. This action served to partially negate the potential cost savings since SNL/NM will be paying more per ton on less emissions.
- 20 NMAC 11.23, Stratospheric Ozone Protection - SNL finalized its Ozone Depleting Substances (ODS) Management Plan (SNL 1997a) in January 1997. This plan describes SNL's strategy to recover and recycle ODSs and provides guidance for the development of individual procedures related to ODS-containing equipment. The document resolves the finding from the 1995 DOE EH-24 audit, which noted the lack of a corporate-wide ODS plan.

20 NMAC 11.42, Operating Permits - The State of New Mexico implements the CAAA, Title $V$ regulations under its State Operating Permit Program in Albuquerque/Bernalillo County. The program received interim approval by the EPA on March 13, 1995, requiring all existing "major sources" to apply for an operating permit by March 13, 1996 . A major source is defined as a facility that emits, or has the potential to emit, 100 tons per year (tpy) of any criteria pollutant, 10 tpy of any single Hazardous Air Pollutant (HAP), or 25 tpy of any combination of HAPs. Based on the actual emissions from the steam plant (Bldg. 605) and the inventory of all boilers, heaters, and standby generators, SNL/NM is a major source for nitrous oxides $\left(\mathrm{NO}_{\mathrm{x}}\right)$. Additionally, SNL/NM has the potential to emit more than 100 tpy of carbon monoxide (CO). DOE submitted SNL/NM's Title V permit application (Volume I) on March 1, 1996; the application was deemed complete on May 1,1996. The COA must issue the Title V Operating Permit on or before March 13, 1998. DOE requested the COA to remove the Lovelace Respiratory Research Institute (LRRI), a private organization, from its Title V Operating Permit application (Volume II) during 1997. 
TABLE 2-3. Summary of Environmental Permits and Registrations in Effect During 1997

\begin{tabular}{|c|c|c|c|c|c|}
\hline Permit Type and/or Facility Name & Location/Building & Permit Number & Issue Date & $\begin{array}{l}\text { Expiration } \\
\text { Date }\end{array}$ & $\begin{array}{l}\text { Regulatory } \\
\text { Agency }\end{array}$ \\
\hline \multicolumn{6}{|l|}{ SEWER WASTEWATER } \\
\hline General & $\begin{array}{l}\text { WW001 Station Manhole, } \\
\text { south of TA-IV at Tijeras Arroyo }\end{array}$ & $2069 \mathrm{~A}-3$ & $7 / 1 / 97$ & $6 / 30 / 99$ & $\mathrm{COA}$ \\
\hline General & $\begin{array}{l}\text { WW006 Station Manhole, } \\
\text { at Pennsylvania Ave. }\end{array}$ & $2069 \mathrm{~F}-3$ & $7 / 1 / 97$ & $7 / 31 / 99$ & $\mathrm{COA}$ \\
\hline Microelectronics Development Laboratory (MDL) & $\begin{array}{l}\text { WW007 Station Manhole, } \\
\text { Bldg. } 858 \text { in TA-I }\end{array}$ & $2069 \mathrm{G}-3$ & $7 / 1 / 95$ & $6 / 30 / 98$ & $\mathrm{COA}$ \\
\hline Advanced Manufacturing Process Laboratory (AMPL) & $\begin{array}{l}\text { WW009 Station Manhole, } \\
\text { Bldg. } 878 \text { in TA-I }\end{array}$ & $2069 \mathrm{H}-3$ & $7 / 1 / 97$ & $8 / 31 / 99$ & $\mathrm{COA}$ \\
\hline General & $\begin{array}{l}\text { WW008 Station Manhole, } \\
\text { south of TA-II at Tijeras Arroyo }\end{array}$ & $2069 \mathrm{I}-2$ & $7 / 1 / 97$ & $9 / 30 / 99$ & $\mathrm{COA}$ \\
\hline General & $\begin{array}{l}\text { WW011 Station Manhole, north of TA-III } \\
\text { (includes TA-III, TA-V, and Coyote Test Field } \\
\text { sewer lines) }\end{array}$ & $2069 \mathrm{~K}-2$ & $6 / 1 / 95$ & $5 / 31 / 98$ & $\mathrm{COA}$ \\
\hline \multicolumn{6}{|l|}{ SURFACE DISCHARGE } \\
\hline $\begin{array}{l}\text { Pulsed Power Development Facilities (Discharge Plan) } \\
\text { (first issue -1988) }\end{array}$ & TA-IV, Lagoons I and II & DP.530 & $2 / 24 / 1995$ & $2 / 24 / 2000$ & NMED \\
\hline \multicolumn{6}{|l|}{ STORM WATER } \\
\hline $\begin{array}{l}\text { National Pollution Discharge Elimination System } \\
\text { (NPDES) "Multi-sector General" Permit }\end{array}$ & Storm water discharges from Stations 4 and 5 & NMR05A181 & $8 / 97$ & $9 / 1 / 2001$ & EPA \\
\hline \multicolumn{6}{|l|}{ RCRA } \\
\hline $\begin{array}{l}\text { Hazardous Waste Management Facility (HWMF) } \\
\text { Module I, II, III }\end{array}$ & TA-II, Bldgs. 958 and 959 & NM5890110518-1 & $8 / 6 / 92$ & $08 / 06 / 2002$ & NMED \\
\hline Thermal Treatment Facility (TTF) & TA-III, Bldg. 6715 & \begin{tabular}{|l} 
NM5890110518-2 \\
\end{tabular} & $12 / 4 / 94$ & $12 / 4 / 2004$ & \begin{tabular}{|l} 
NMED \\
\end{tabular} \\
\hline $\begin{array}{l}\text { Resource Conservation and Recovery Act (RCRA)- } \\
\text { Hazardous and Solid Waste Amendments (HSWA)- } \\
\text { Module IV }\end{array}$ & ER sites & NM5890110518-1 & $8 / 26 / 93$ & $9 / 20 / 2002$ & NMED/EPA \\
\hline $\begin{array}{l}\text { Resource Conservation and Recovery Act (RCRA) - } \\
\text { Temporary Unit (TU) (permit/modification to HSWA } \\
\text { module) }\end{array}$ & TA-III & $\begin{array}{l}\text { Part of CAMU } \\
\text { permit }\end{array}$ & $9 / 97$ & June 1999 & NMED \\
\hline $\begin{array}{l}\text { Resource Conservation and Recovery Act (RCRA) - } \\
\text { Corrective Action Management Unit (CAMU) - } \\
\text { proposed modification }\end{array}$ & TA-III & NM5890110518 & $9 / 97$ & June 2003 & NMED \\
\hline $\begin{array}{l}\text { RCRA Part A and B Permit Applications for the RCRA } \\
\text { component in mixed waste (MW) stored at Hazardous } \\
\text { Waste Management Units }\end{array}$ & $\begin{array}{l}\text { - Radioactive Mixed Waste } \\
\text { Management Facility (RMWMF), Bldg. } 6920 \\
\text { - } 7 \text { Manzano Bunkers } \\
\text { - Interim Storage Site (ISS), TA-III, Bldg. } 6921 \\
\text { - High Bay TA-V, Bldg. } 6596\end{array}$ & NM5890110518 & $\begin{array}{l}\text { Interim status } \\
\text { first submitted } \\
8 / 90 ; \text { Rev. } 3 \\
11 / 96\end{array}$ & $\begin{array}{l}\text { Pending } \\
\text { Review* }\end{array}$ & NMED/EPA \\
\hline
\end{tabular}

NOTE: tRegistration $=$ Certificate, no permit required.

f†Approval $=$ EPA does not issue a permit

* Submitted and awaiting agency review. 

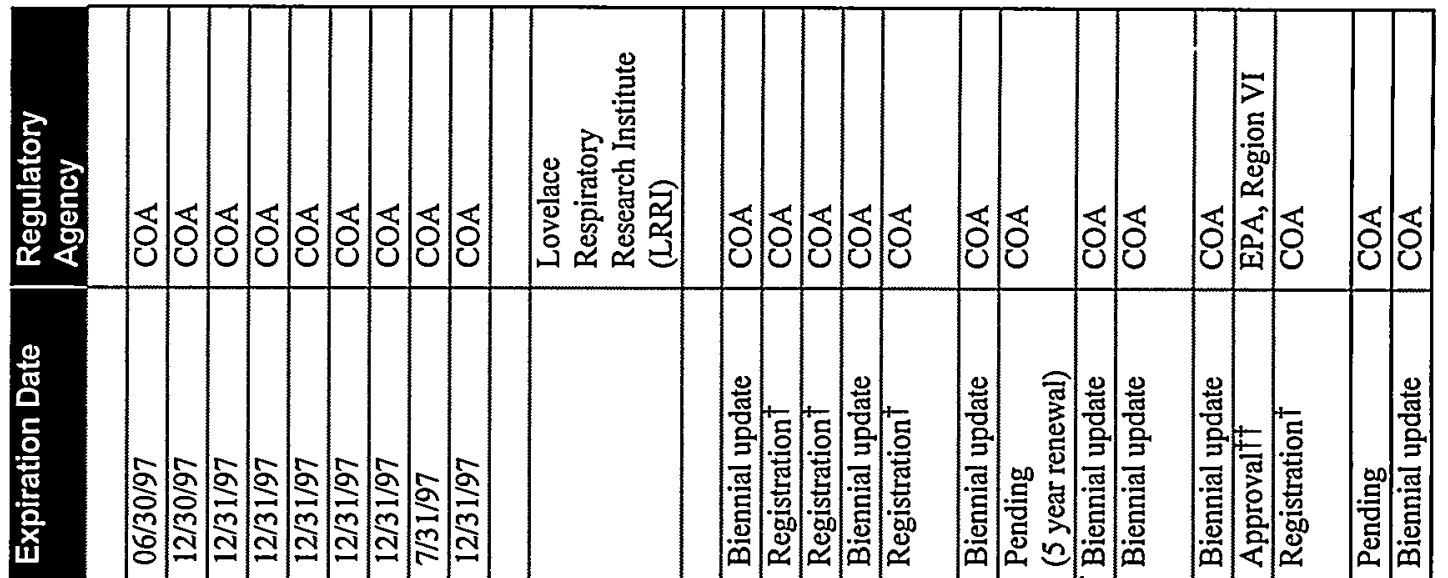

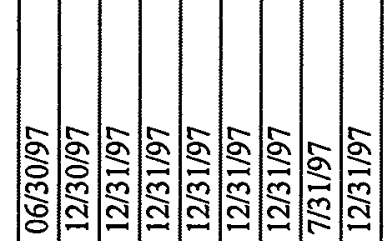

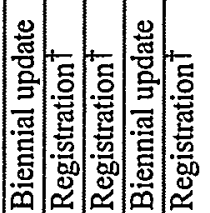

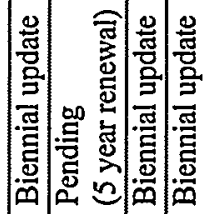

要

|

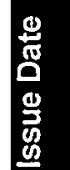

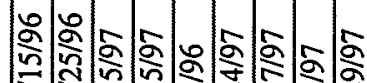

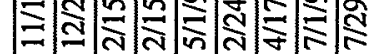

ஊ ते

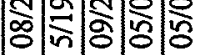
各商高空

䒽昰

:

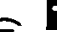

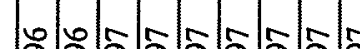

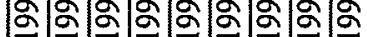

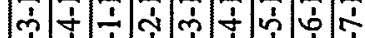

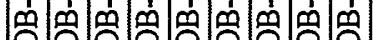

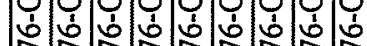

政

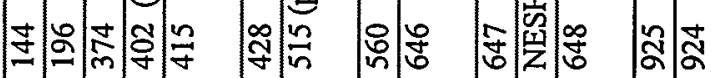

올

范

工

$\stackrel{2}{\llcorner}$

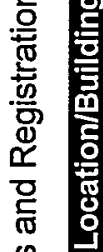

里

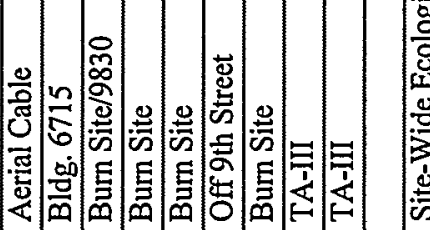

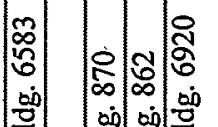
잉 8 年

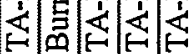

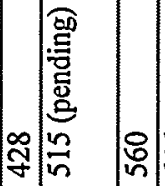
通

(

2
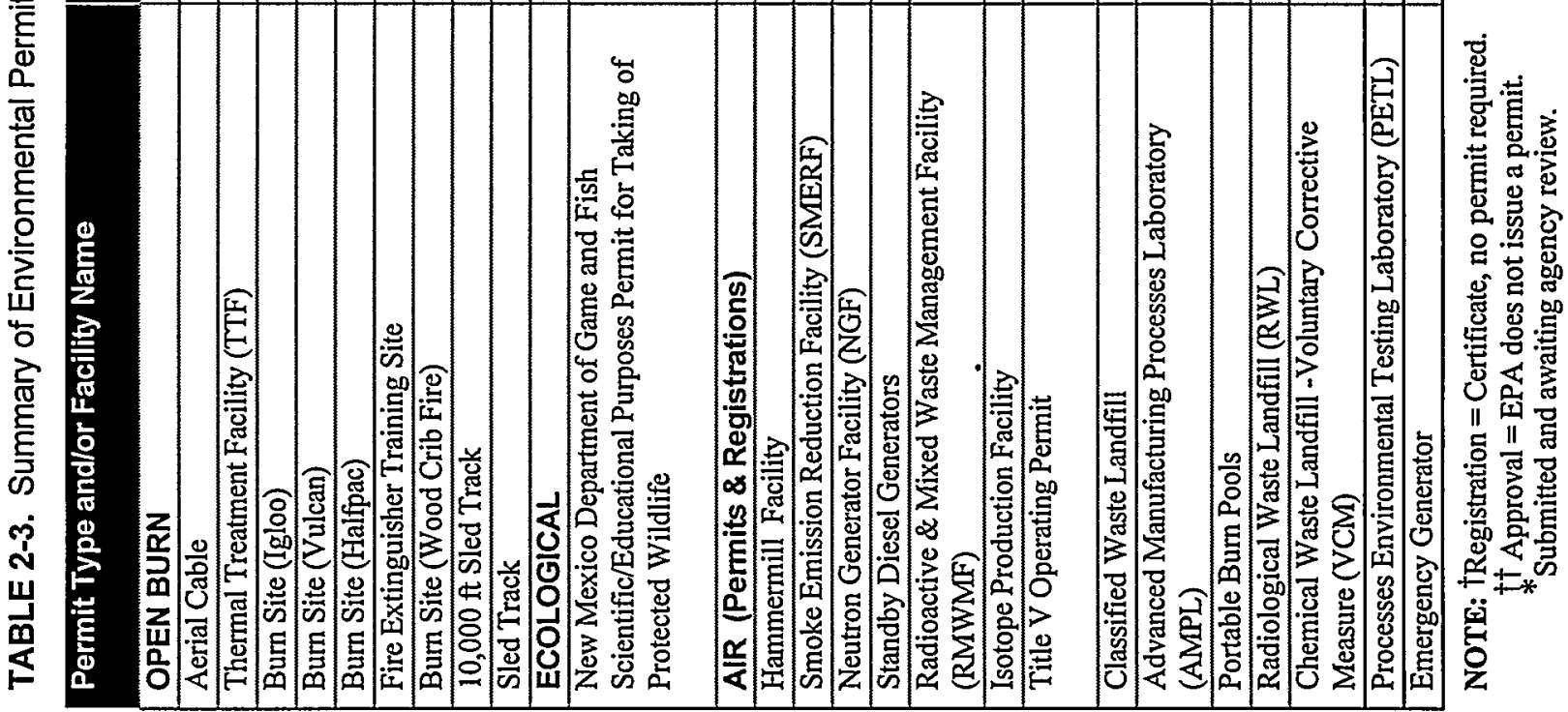
- New EPA Standards for Particulate Matter (PM) and Ozone $\left(\mathrm{O}_{3}\right)$ - On July 16 , 1997, the EPA adopted new standards on PM and ground level $\mathrm{O}_{3}$. The standards regulate $\mathrm{PM}$ to 2.5 microns and $\mathrm{O}_{3}$ to 0.08 parts per million (ppm) measured over 8 hours. The new standards could impact SNL/NM by changing the attainment status for Bernalillo County and thus changes to current and future operations.

- Mixed Waste (MW) Compliance Although treatment of MW has been initiated and an initial shipment was sent for disposal in early 1998, compliance with RCRA regulations (RCRA 3004j) continues to be an issue. Large quantities of $\mathrm{MW}$ remain in storage at SNL/NM past the one year maximum storage time for hazardous wastes. SNL/NM is, however, in compliance with the Federal Facility Compliance Act (FFCAct), which acknowledges the lack of $\mathrm{MW}$ treatment capacity.' Treatment technologies have recently been developed, and all accumulated MW will be shipped offsite for disposal over the next several years.

\section{AUDITS AND}

SNL/NM ES\&H operations are routinely subjected to audits by external regulatory agencies, appraisals by DOE, and assessments by internal independent organizations. Table 2-4 lists audits and appraisals conducted in 1997 by external agencies for various environmental programs at SNL/NM.

Audits identify issues that are reported as either "findings," "observations," or "noteworthy practices." Findings denote non-compliance and require corrective actions. Observations may be either positive or negative and may or may not require a follow up action. Noteworthy practices identify positive conditions.
Addressing issues resulting from audits and appraisals is the responsibility of each program area.

\section{Corporate ES\&H Self Assessments}

SNL/NM is in the process of instituting a corporate ES\&H self assessment program in which the responsible line organization conducts its own assessment of its programs and activities. This will be coupled with the assessments currently performed by other SNLinternal independent organizations. The main focus of this effort will be to provide a mechanism for SNL/NM organizations to assess their own performance and share the results with DOE and external regulatory agencies. The information provided will be used to assist external agencies in their oversight activities. Successful implementation of a corporate ES\&H self assessment program is expected to result in an overall reduction in the number of ES\&H audits and appraisals.

\section{RELEASES AND OCCURRENCES}

Occurrence reporting is tracked by the Compliance and Metrics Department. All SNL/NM occurrences are entered into the Occurrence Reporting Processing System (ORPS) database. Corrective actions are also tracked through the database, although final responsibility for completing corrective actions rests with each affected organization. Table 2-5 presents a 5-year history of SNL/NM's occurrence reporting status.

DOE Order 232.1a, Occurrence Reporting and Processing of Operations Information (DOE 1997c) establishes a DOE system for identification, categorization, notification, analysis, reporting, follow-up, and close-out of occurrences. DOE notifies appropriate agencies based on the nature of each occurrence. 
TABLE 2-4. Audits and Appraisals Conducted by External Agencies in 1997

\begin{tabular}{|c|c|c|c|}
\hline $\begin{array}{l}\text { Appraising } \\
\text { Agency }\end{array}$ & Title & $\begin{array}{l}1997 \text { Audit } \\
\text { Period }\end{array}$ & Summary \\
\hline - $\mathrm{DOE} / \mathrm{AL}$ & $\begin{array}{l}\text { Preaudit assistance visit prior } \\
\text { to the DOE/EH evaluation of } \\
\text { safety management at } \\
\text { SNL/NM }\end{array}$ & April 28 to May 2 & $\begin{array}{l}\text { DOE conducted this assessment to } \\
\text { prepare SNL for the DOE/HQ EH-2 } \\
\text { audit. }\end{array}$ \\
\hline $\begin{array}{ll} & \mathrm{DOE} / \mathrm{AL} \\
& (\mathrm{EMD})\end{array}$ & $\begin{array}{l}\text { Emergency preparedness } \\
\text { evaluation }\end{array}$ & April 1 & $\begin{array}{l}\text { Problems were found with Incident } \\
\text { Command System (ICS) integration } \\
\text { with Kirtland Fire Dept. and with the } \\
\text { classification of events. No fines } \\
\text { were incurred. }\end{array}$ \\
\hline $\begin{array}{ll}\text { DOE/HQ } \\
(\mathrm{EH})\end{array}$ & $\begin{array}{l}\text { Enforcement of fact-finding } \\
\text { visit on RMWMF hot particle } \\
\text { incident }\end{array}$ & February 17 & $\begin{array}{l}\text { A total of } 22 \text { Corrective Actions } \\
\text { (CAs) were implemented and } \\
\text { completed. Most concerned } \\
\text { rewriting procedures. Previous } \\
\text { health physics survey procedures had } \\
\text { been inadequate. Sorting procedures } \\
\text { were also improved. A final fine of } \\
\$ 56,250 \text { was assessed. }\end{array}$ \\
\hline $\begin{array}{ll}\mathrm{DOE} / \mathrm{HQ} \\
(\mathrm{EH}-2)\end{array}$ & EH-2 Audit for ES\&H & June 3 to August 29 & $\begin{array}{l}\text { Some of the concerns the audit cited } \\
\text { were the need for better Integrated } \\
\text { Safety Management System (ISMS) } \\
\text { implementation, better flow-down of } \\
\text { DOE directives, more control in } \\
\text { work process procedural contents, } \\
\text { improved work permits, more } \\
\text { oversight in construction safety, and } \\
\text { improved documentation in several } \\
\text { ES\&H programs. }\end{array}$ \\
\hline - NMED & $\begin{array}{l}\text { Annual "unannounced" audit } \\
\text { for hazardous waste and } \\
\text { mixed waste (MW) } \\
\text { management activities }\end{array}$ & June 25 to July 2 & $\begin{array}{l}\text { Several violations were noted } \\
\text { including improper labeling, an open } \\
\text { container, and paperwork errors. A } \\
\text { final assessment of } \$ 18,000 \text { in fines } \\
\text { was made by NMED. All violations } \\
\text { were corrected. The audit resulted in } \\
\text { an occurrence in } 1998 \text {. }\end{array}$ \\
\hline - NMED & $\begin{array}{l}\text { Evaluation of solid waste } \\
\text { management activities }\end{array}$ & October 29 & No violations were noted. \\
\hline
\end{tabular}

NOTE: $\quad$ RMWMF = Radioactive and Mixed Waste Management Facility $\mathrm{EMD}=$ Emergency Management Division DOE/AL = U.S. Department of Energy/Albuquerque Operations Office $\mathrm{DOE} / \mathrm{EH}=$ U.S. Department of Energy/Environmental Health $\mathrm{DOE} / \mathrm{HQ}=\mathrm{U} . \mathrm{S}$. Department of Energy/Headquarters NMED $=$ New Mexico Environment Department 
TABLE 2-5. Summary of Environmental Occurrence Categories Over the Past Five Years

\begin{tabular}{|c|c|c|c|c|}
\hline Year & $\begin{array}{c}\text { Number of Waste } \\
\text { Management- } \\
\text { Related Releases }\end{array}$ & $\begin{array}{c}\text { Number of Water } \\
\text { Quality-Related } \\
\text { Releases }\end{array}$ & $\begin{array}{c}\text { Number of Air } \\
\text { Quality-Related } \\
\text { Releases }\end{array}$ & $\begin{array}{c}\text { Total Reportable } \\
\text { Releases to the } \\
\text { Environment }\end{array}$ \\
\hline 1997 & $7(6)^{*}$ & $5(3)^{*}$ & 1 & $13(10)^{*}$ \\
\hline 1996 & 0 & 3 & 0 & 3 \\
\hline 1995 & 2 & 2 & 2 & 6 \\
\hline 1994 & 4 & 7 & 0 & 11 \\
\hline 1993 & 4 & 4 & 1 & 9 \\
\hline
\end{tabular}

NOTE: This 1997 table differs from the one presented in the 1996 ASER. The above data better represents how SNL/NM actually tracks its occurrences.

* The number in parentheses represents the incidences for which an occurrence report was prepared. One waste management release involving a hydraulic oil release on August 4, 1997 was not captured in the text since a report was not written. Two $\mathrm{pH}$ excursions also not discussed in the text are, however, discussed in chapter 6 of this report.

There are three types of environmental occurrences, each of which is determined by the severity of the event. An occurrence can also be incurred as the result of an audit finding or other break in permit compliance and/or official agreement. The following defines the three types of environmental occurrences tracked by SNL/NM. In 1997, only one was an "unusual occuurrence" involving the oil spill on September $4^{\text {th }}$.

Emergency Occurrence - Any actual or potential release of material that would put communities or wildlife in great harm. The Emergency and Environmental Management Department stages routine mock emergencies to test the Incident Command System (ICS) and SNL/NM's ability to respond and coordinate with other agencies in the event of an actual emergency. There are three levels within this category that are dependent on the potential offsite impact. SNL/NM has never had an emergency occurrence. All releases in this category would be reportable to outside state or federal agencies and DOE.

Unusual Occurrence - Includes CERCLA reportable quantity (RQ) releases and other more significant events based on quantities released or damage incurred. All releases in this category are reported to outside state or federal agencies and DOE.
Off-Normal Occurrence - An unplanned release that adversely affects the environment but does not exceed federal limits, involve personal injury, or result from the violation of safety and operational rules.

The following list summarizes the ten incidences in 1997 for which occurrence reports were prepared. Three additional releases are not captured here. Two involved $\mathrm{pH}$ excursions to the public sewer system and are discussed in chapter 6 . The other involved a minor hydraulic oil spill on August 4, 1997. All releases were reported to applicable outside regulatory agencies.

1. Water Quality - On January 28,1997 , a pH excursion occurred from the Advanced Processes Development Laboratory (AMPL) (Bldg. 878). After the work day was over at 4:30 p.m., the pH dropped below the limit of 5 to approximately 3.4 and remained at this level for about 1.5 hours. The $\mathrm{pH}$ returned to normal range and then dropped again 15 minutes later to 3.6 for about 2.5 hours. It returned to normal range again before dropping to 3.6 for another hour. The $\mathrm{pH}$ excursion ended at about 10:00 p.m. The violation of wastewater discharge permit $\# 2069$ H-3 was reported to the COA. No fines were incurred. 
2. Air Quality - On February 26, 1997 a paperwork error was discovered concerning an Open Burn Permit (\#76-OB-3-1996) resulting in an occurrence. The permit was issued to cover a series of rocket propellant combustion tests for the Rocket Plume Chemical Characterization Project. The tests were conducted between November 1996 and January 1997 at the Sol se Mete Canyon Cable Site. The permit specified five burns with a propellant mass of $200 \mathrm{~kg}$ per burn. The total mass was not to exceed $1,000 \mathrm{~kg}$ for all tests in the series. SNL/NM conducted 13 tests instead of the specified five. However, the total propellant mass used for all tests was only $276 \mathrm{~kg}$ (each test used less than $35 \mathrm{~kg}$ ). The occurrence was reported to the COA. No fines were incurred.

3. Waste Management - On the morning of May 16, 1997, a minor oil spill was discovered on the north side of Bldg. 6911 in TA-III. A 30-gallon oil storage barrel containing $18 \mathrm{gal}$ of common corn oil leaked onto the ground. (The oil was used in a constant temperature oil bath.) Approximately 1.5 cubic meters $\left(\mathrm{m}^{3}\right)$ of soil was excavated and disposed of as solid waste. The spill was reported to NMED. No fines were incurred.

4. Waste Management - On the morning of June 9, 1997, a leak from an underground storage tank (UST) used to store cooling water was discovered at the Large Melt Facility (LMF). The water was a regulated substance due to the coolant mixture ratio of ethylene glycol to water (30:70). Approximately 475 gal of cooling solution was lost. The spill was reported to NMED. No fines were incurred.

5. Waste Management - On Saturday night June 14, 1997, a high pressure chilled water line failed due to improper installation of an elbow joint. The discharge released 15,000 to $20,000 \mathrm{gal}$ of treated chilled water to the ground. An inspection had been performed before the line was charged and although a potential problem was noted, it was decided to activate the line in order to supply cooling water to Bldg. 858 over the weekend. The line failed 12 hours later. The water contained 350 ppm of NALCO 2833, a rust inhibitor and therefore was reportable to NMED. NALCO 2833 at this concentration (sodium nitrate at 20 to 40 percent) had a low impact to the environment. No fines were incurred.

6. Waste Management - On July 29, 1997 a breach in the boundary at Environmental Restoration (ER) Site 228 released depleted uranium (DU) near the Tijeras Arroyo. The area was only partially remediated due to the steep slope. The boundary of the ER site was enlarged to include the breached area. The situation was reported to the NMED. No fines were incurred.

7. Waste Management - On September 4, 1997 , approximately 450 gal of hydraulic fluid was released to the soil from a break in the underground piping system at the Centrifuge Facility (Bldg. 6523). The facility's system includes several hundred feet of oil delivery and return lines used to hydraulically control two centrifuges. The oil and contaminated soil were collected and disposed of as hazardous waste. The discovery of the oil leak also led investigators to realize that the entire system, which was built in the 1950 s, was subject to UST regulations and had not been previously registered. This was in violation of NMED regulations. It was decided to replace the system with a new aboveground piping system to prevent further system failures. The new above-ground system will not be subject to UST regulations. The occurrence was reported to the NMED. No fines were incurred.

8. Waste Management - On September 12, 1997, a release of hydraulic fuel was discovered at the Gamma Irradiation Facility 
(GIF). The oil was used to hydraulically operate a shield door system. A total of $29 \mathrm{gal}$ of oil leaked from the system as determined by additions made to the reservoir since May 1997. The oil leaked past the gravel bed into the ground below the building. The situation was reported to the NMED. No fines were incurred.

9. Water Quality - On the afternoon of October 25, 1997, sewage overflowed onto the surface from a sewage holding tank located at the Steam Plant (Bldg. 898) in TA-I. This was caused by a flush valve on one of the toilets, which had ran continuously for 33 hours overflowing the tank. An estimated 7,500 to 10,000 gal of raw sewage flowed $300 \mathrm{ft}$ from its source and infiltrated the surface at a construction site. Workers at the site were informed of the potential health hazards and given precautions for contact with any untreated sewage. The incident was reported to the NMED. No fines were incurred.

10. Water Quality - On November 12, 1997 , another sewer discharge occurred after a paving contractor inadvertently backed over a sewer clean out line and broke off the top. Dirt and gravel fell into the sewer system through the open pipe. The damage went unnoticed until the sewer line backed up due to the blockage. Approximately 60 to 100 gal escaped to the parking lot east of Bldg. 887. The situation was reported to the NMED. No fines were assessed.

\section{SUMMARY OF REPORTING REQUIREMENTS}

This section briefly describes the reporting requirements necessary for all non-routine and routine releases of pollutants or hazardous substances. Release information may be used to evaluate facility operation compliance, waste handling programs, and emergency response programs.

The following four release reporting documents are required by external organizations other than DOE.

- Reportable Quantity (RQ) Accidental Release Reporting - RQ release reporting is required by CERCLA and SARA Title III. CERCLA requires that any release to the environment in any 24-hour period of any pollutant or hazardous substance in a quantity greater than or equal to the $R Q$ must be reported immediately to the National Response Center (NRC) (telephone number 800-424-8802). However, if the release is "federally permitted" under CERCLA Section 101(10)H, it is exempted from CERCLA reporting. This reporting exemption also applies to any "federally permitted" release under SARA Title III. In 1997, no release exceeding the RQ was reported by SNL/NM.

- Radioactive Effluent Information System/Onsite Discharge Information System (EIS/ODIS) Annual Report DOE Order 5400.1, General Environmental Protection Program, requires that data about radioactive effluents and onsite discharges from the previous year for all planned and unplanned releases must be reported to the Waste Information System Branch of EG\&G, Idaho, Inc., by April 1st each year (DOE 1990a). The EIS/ODIS report for 1997 , submitted in 1998, covered all routine and non-routine releases from SNL/NM operations. Unplanned releases of radioactive materials or effluents (such as spills and leaks) whether onsite or offsite, are also be reported to EG\&G. This is in addition to meeting the reporting requirements of DOE Order 232.1a (DOE 1997c). Releases that are of no environmental concern, including those that are subsequently cleaned up, do not need to be reported. 
- National Emission Standards for Hazardous Air Pollutants (NESHAP) for Radionuclides Other than Radon from DOE Facilities (Subpart H) Annual Report - NESHAP 40 CFR 61, Subpart H, requires that an annual report be submitted to the EPA for all DOE sites that release radionuclide air emissions. The report must be submitted to the EPA by June 30 following the reporting year. The report includes the calculated effective dose equivalent (EDE) in millirem per year (mrem/yr) for the maximally exposed individual (MEI) and the population dose in person-rem/yr. Section 5.4 presents results of the dose assessment to the public from SNL/NM operations in 1997 (SNL 1998b).

- Emergency Planning and Community Right-to-Know Act (EPCRA), Section 313, Toxic Release Inventory (TRI) - The TRI report is required by 40 CFR 372 , EPCRA for facilities that have a Standard Industrial Classification (SIC) code from 20 through 39 and that use listed toxic chemicals in quantities greater than 10,000 $\mathrm{lb} / \mathrm{yr}$ for any of the listed chemicals. EO 12856, Federal Agency Compliance with Right-to-Know Laws and Pollution Prevention Requirements, requires federal facilities meeting reporting thresholds to submit TRI reports under EPCRA. SNL/NM has been filing TRI reports with DOE and the EPA since 1991. However, due to a recent change in the regulations, SNL/NM was under the reporting threshold limit in 1997 and, therefore, did not file a TRI report. 


\section{Environmental Programs INFORMATION}

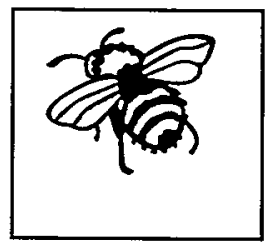

$\mathrm{E}$ nvironmental monitoring began at SNL/NM in 1959 at which time the principal objective was to monitor radioactive effluents and any associated environmental impacts. Since then, environmental programs, along with other Environment, Safety, and Health (ES\&H) activities, have greatly expanded at SNL/NM. The Tiger Team Investigations, initiated by DOE in 1990, provided further impetus to continue development and expansion of ES\&H programs to meet DOE objectives.

Environmental program areas covered in this chapter include the Environmental Restoration (ER) Project, waste management programs, the Pollution Prevention (P2) Program, the Oil Storage and Spill Containment Program, and the National Environmental Policy Act (NEPA) Program. Environmental monitoring programs covered in subsequent chapters of this report include the Terrestrial Surveillance Program, air quality programs, water quality programs, and groundwater monitoring and protection programs (Chapters $4,5,6$, and 7 , respectively).

Environmental progress at SNL/NM is tracked through performance measures and indicators, including annual summaries such as this report. Trends in compliance status and/or other significant program results over the past 5 years are given where appropriate. Awards and commendations are highlighted where available.

SNL/NM has established and implemented environmental management programs to meet or exceed the requirements of federal, state, and local environmental regulations, Executive Orders (EOs), and DOE orders. Besides meeting basic regulatory compliance requirements, other environmental investigations are ongoing to verify that contamination is not accumulating in the ambient environment or to identify potential concerns where they exist.

SNL/NM's policy is to minimize risks to the public and the environment to as low as reasonably achievable (ALARA) levels. DOE Order 5400.1, General Environmental Protection Program, and DOE Order 5400.5, Radiation Protection of the Public and the Environment, drive applicable environmental programs including those that are not externally regulated (DOE 1990a, DOE 1993a).

\subsection{ENVROMMENTAL RESTORATION (ER) PROJECT}

The ER Project is a phased DOE project to identify, assess, and remediate contaminated DOE facilities from past spill, release, and disposal activities. The DOE Kirtland Area Office (DOE/KAO) has oversight over SNL/NM's ER sites. At SNL/NM, the ER Project is administered under four departments within the Geoscience and Environment Center.

The ER Project at SNL/NM was initiated in 1990 to implement assessment and remediation for ER sites at SNL/NM, SNL/CA, the Kauai Test Facility (KTF), and other locations under $\mathrm{DOE} / \mathrm{KAO}$ jurisdiction. ER remediation at SNL/NM is projected to be completed by the year 2001-ahead of most other installations in the DOE complex. 
The ER Project received an outstanding programmatic performance in the DOE/SNL appraisal system in 1997.

\section{Regulatory Authority}

ER sites are regulated by the Resource Conservation and Recovery Act (RCRA) as applied to SNL/NM under the Hazardous and Solid Waste Amendments Act of 1984 (HSWA), as specified in Module IV of the RCRA Part B Operating Permit. The New Mexico Environment Department (NMED) implements RCRA regulations and issues all applicable permits. SNL/NM remains in compliance with permit conditions and is currently ahead of schedule for assessment and cleanup activities.

\section{SNL/NM ER Site Historical Status}

The initial identification of ER sites at SNL/NM was completed in 1987. At that time 117 sites were identified in the initial Comprehensive Environmental Assessment and Response Program (CEARP) Phase I: Installation Assessment (DOE 1987). By 1992, the year SNL/NM's ER Program was initiated, a total of 172 sites were identified. By the end of fiscal year 1992 (FY92), the number of identified sites at SNL/NM reached a maximum of 219 . Many of these sites were proposed for No Further Action (NFA) based on insignificant contamination present or after remediation had been accomplished. From 1993 to 1995, 109 sites were investigated and proposed for NFA after assessment and/or remediation. At the end of FY97, 146 sites remained on the RCRA permit.

DOE's Office of Environmental Management (DOE/EM) has developed a complex-wide ER plan titled Accelerating Cleanup: Focus on 2006 - Discussion Draft (DOE 1998a). This summary-level plan, with associated cost and schedule information, includes a comprehensive overview of SNL/NM's ER project describing its current status and future plans. The Environmental Restoration (ER) Site Atlas (SNL 1996b) lists SNL/NM's current ER sites. Table 3-1 shows the progress and status of the ER
Project since its inception in 1992. Table 3-2 lists important ER documents.

\section{Activities and Future Plans}

Most of the 146 ER sites remaining to be addressed have been proposed for NFA and are pending regulatory review. It is estimated that there are fewer than 30 sites remaining at SNL/NM that will require some level of cleanup. During 1997, 30 sites were proposed for NFA; of these, seven were approved. SNL/NM will continue to actively pursue the closure of remaining proposed NFA sites by working with the NMED to provide adequate and/or further verification, as necessary, for a successful determination.

A total of four ER sites were remediated in 1997 under the Voluntary Corrective Measure (VCM) process:

- Site 91 - Thunder Range Lead Firing Site

- Site 12B - Burial Site/Open Dump

- Site 28a - Mine Shafts

- $\quad$ Site 27 - Animal·Disposal Pit

The Chemical Waste Landfill (CWL) is the most significant cleanup project remaining to be addressed by the ER Project. Other areas of ER concern include the Classified Waste Landfill in TA-II, Site 16 at Tijeras Arroyo (open dump at Arroyo del Coyote), Site 8 (open dump at Coyote Canyon Blast Area), and potential groundwater contamination in Technical Areas I, II, III, and V.

Based on current budget projections, the SNL/NM ER Project will maintain a high level of cleanup activity through FY99, after which only the CWL will remain to be completed by 2001.

Other ER activities completed in 1997 include:

- The continuation of the Ecological Risk Evaluation Methodology for ER sites proposed for NFA 
TABLE 3-1. Summary of ER Project Status Since the Program's Inception in 1992

\begin{tabular}{|c|c|c|c|c|c|c|}
\hline Year & $\begin{array}{l}\text { Total ER } \\
\text { Sites at } \\
\text { Start of } \\
\text { FY }^{\star}\end{array}$ & $\begin{array}{l}\text { ER Sites } \\
\text { Proposed } \\
\text { for NFA } \\
\text { in FY* }\end{array}$ & $\begin{array}{l}\text { Sites } \\
\text { Approved for } \\
\text { NFA in FY* }\end{array}$ & $\begin{array}{l}\text { Corrective } \\
\text { Actions } \\
\text { Completed } \\
\text { by End of FY* }\end{array}$ & $\begin{array}{l}\text { New ER Sites } \\
\text { Identified } \\
\text { During FY* }\end{array}$ & $\begin{array}{l}\text { Total ER } \\
\text { Sites at End } \\
\text { of FY* }\end{array}$ \\
\hline 1997 & 153 & 30 & 7 & 4 & 0 & 146 \\
\hline 1996 & 155 & 35 & 2 & 29 & 0 & 153 \\
\hline 1995 & 191 & 61 & 36 & 34 & 0 & 155 \\
\hline 1994 & 219 & 48 & 28 & 3 & 0 & 191 \\
\hline 1993 & 219 & 0 & 0 & 0 & 0 & 219 \\
\hline 1992 & 172 & 0 & 0 & 0 & 47 & 219 \\
\hline
\end{tabular}

NOTE: *FY $=$ October 1 to September 30

NFA $=$ No Further Action

TABLE 3-2. Important Documents for the ER Project

\begin{tabular}{|l|l|}
\hline Program Document & Reference \\
\hline Program Implementation Plan for Albuquerque Potential Release Sites & SNL 1995a \\
\hline Environmental Restoration (ER) Site Atlas & SNL 1996b \\
\hline $\begin{array}{l}\text { The Chemical Waste Landfill Final Closure Plan and Postclosure Permit } \\
\text { Application (including "Sampling and Analysis Plan for Groundwater } \\
\text { Assessment Monitoring at the Chemical Waste Landfill") }\end{array}$ & \\
\hline $\begin{array}{l}\text { Comprehensive Environmental Assessment and Response Program (CEARP) } \\
\text { Phase I: Installation Assessment }\end{array}$ & DOE 1987 \\
\hline Accelerating Cleanup: Focus on 2006-Discussion Draft & DOE 1998a \\
\hline Environmental Assessment of the ER Project at SNL/NM & DOE 1996a \\
\hline Workbook: Future Use Management Area 1 & DOE 1995a \\
\hline Workbook: Future Use Management Area 2 & DOE 1995b \\
\hline Workbook: Future Use Management Area 3, 4, 5, and 6 & DOE 1996b \\
\hline Workbook: Future Use Management Area 7 & DOE 1996c \\
\hline
\end{tabular}


- The final prioritization of all remaining ER sites at SNL/NM involving significant stakeholder input

\section{Chemical Waste Landfill (CWL)}

The CWL was used for chemical disposal from 1962 to 1985 , before it was permanently closed in 1988. Trichloroethylene (TCE), a volatile organic compound (VOC), has been discovered in the groundwater $500 \mathrm{ft}$ beneath the site at concentrations slightly above the EPA's drinking water standard. The CWL is currently under RCRA interim status issued by the NMED in 1985 and is managed in accordance with the Chemical Waste Landfill (CWL) Final Closure Plan and Postclosure Permit Application (SNL 1992a), which incorporates remedial corrective actions with respect to the TCE contamination. The ER Project is continuing assessment work to evaluate the impacts to groundwater from TCE contamination. In 1997, initial remediation was begun at the CWL using vapor extraction remediation. Monitoring of the site will continue after final remediation is completed by 2001 .

\section{Temporary Unit/Corrective Action Management Unit (TU/CAMU)}

The TU/CAMU has been designed to facilitate the handling of large volumes of contaminated soils generated by SNL/NM's ER activities, most of which will come from the cleanup of the CWL. The CAMU is expected to treat all of SNL/NM's treatable ER-derived RCRA waste by the end of 2001. This 23-acre facility is located on ER Site 107 northwest of the Radioactive and Mixed Waste Management Facility (RMWMF).

Construction of the TU/CAMU will be completed in a two-phase approach. Phase 1 began in November 1997 and was completed in April 1998. This phase primarily prepared the facility for bulk waste storage. Phase 2 will include waste treatment operations and final disposition. Phase 2 is scheduled to commence in October 1998 and be completed by December of the same year.
The TU will stage and store ER waste for up to 1 year before it is processed at the CAMU, where soils will be treated to reduce contamination to trace levels, where possible. After treatment, waste that meets required treatment standards will be permanently buried onsite at the CAMU in a lined land disposal cell. Disposal options for CAMU-treated soils will be based on the Superfund Land Disposal Restrictions (LDR) Guide 6A (EPA 1990).

Treatment to be performed at the CAMU will include the following methods:

- Soil washing to remove toxic metals

- Low temperature thermal desorption to volatilize organic compounds, which will be captured in filters

- Stabilization to bind contaminants and render them unleachable

ER waste that does not meet the LDR standards will not be disposed of at the CAMU, but will be shipped offsite to other permitted treatment and disposal facilities.

The CAMU received a permit to operate in September 1997; the permit also encompasses the storage operations at the TU.

\section{2 mastremuncenter PROGRAMS}

Waste management at SNL/NM is conducted under two departments: the Solid and Hazardous Waste Department and the Radioactive and Mixed Waste Department. In addition to site-generated waste, waste and recycled materials may be received from offsite sources including SNL/CA, LANL, other DOE sites, and KAFB. Waste handled at SNL/NM falls into four primary categories: 
- Sanitary solid waste

- Hazardous waste

- Low-level radioactive waste (LLW)

- Mixed waste (MW) (radioactive and hazardous constituents)

Depending on the waste category, waste management may include characterization, treatment, recycling, packaging, storing, and transportion to offsite disposal facilities. The layout and operations at each of SNL/NM's three waste handling facilities is briefly described below:

- Hazardous Waste Management Facility (HWMF) - Located in TA-II and consists of a main facility for waste handling and storage and an adjoining compound for additional storage. The primary waste handling building is used to validate and sort waste categories for initial accumulation and also package waste for transportation. RCRA hazardous chemical waste makes up the bulk of all hazardous waste handled at the HWMF. Additionally, polychlorinated biphenyl (PCB) and asbestos waste, regulated under the Toxic Substances Control Act (TSCA), is handled by the HWMF. All hazardous waste categories are recycled where possible.

- Radioactive and Mixed Waste Management Facility (RMWMF) Located in the southeast corner of TA-III and consists of an enclosed compound with an administration trailer just outside the main gate. The primary waste handling building at the RMWMF (Bldg. 6920) is equipped with a main control room for monitoring activities and controlling air flow throughout the facility. Handling bays, sorting rooms, and various waste storage areas operate under negative air flow to ensure that all emissions are channeled through the facility's stack. The RMWMF's radionuclide emissions are regulated under National Emission Standards for Hazardous Air Pollutants (NESHAP). The Waste Assay Facility (Bldg. 6921) is also currently set up for laboratory and waste treatment activities. Transportainers used to store waste are located throughout the compound. The RMWMF handles primarily low-level radioactive waste (LLW) and mixed waste (MW). Small quantities of transuranic (TRU) waste are also handled periodically.

- Solid Waste Transfer Facility (SWTF) Located within a fenced compound in TAII. The SWTF handles non-hazardous sanitary solid waste consisting primarily of office trash and recyclable paper and cardboard. The primary waste handling building houses a multi-story industrial compactor/baler. Bales of compacted trash and recycled material are produced weighing up to 1 ton each. The disposal process at the facility begins with initial waste screening. All waste or recyclable material is dumped directly onto the bay floor for inspection and sorting. Construction debris, food service garbage, liquids, pressurized cans, and light bulbs are some of the categories not accepted at the SWTF. After screening, a front-end loader scoops the material onto the conveyor belt and into the baler. All bales of recycled material are stored separately from the solid waste. Waste bales are stored outside until they can be transported to a local landfill.

SNL/NM's individual waste management programs are described in the following subsections. Documents relevant to all waste management program areas are listed at the end of section 3.3 (Table 3-11).

\subsubsection{Hazardous Waste Management}

SNL/NM is classified as a large-quantity generator with respect to RCRA-hazardous waste. The HWMF is responsible for handling, packaging, storing, recycling, and shipping all RCRA-regulated waste and other regulated hazardous waste categories. 
The HWMF operates under SNL/NM's RCRA Part B Operating Permit. This facility also complies with the provisions of TSCA for asbestos waste (40 CFR 763) and PCB waste (40 CFR 761). Used oil is recycled in accordance with 40 CFR 279. Biohazardous and medical waste is handled in accordance with State of New Mexico regulations (20 NMAC 9.1).

\section{Cradle to Grave Tracking}

Hazardous waste is tracked from the point of generation to final disposal through meticulous documentation at each waste-handling step. Each generator at SNL/NM initiates the "cradle to grave" tracking process by filling out a Disposal Request Form describing the quantity and type of waste requested for pickup. Generators characterize their own waste by either process knowledge or, if necessary, sampling and analysis. Each individual hazardous waste item is labeled with a bar code for tracking at the generator site before pickup. An individually coded waste item typically is a bottle, plastic bag, or other small item that contains toxic materials. The Disposal Request Form is sent to the HWMF for evaluation where it is assigned a U.S. Department of Transportation (DOT) hazard class and RCRA code, if applicable.

Once the waste is received at the HWMF it is unpacked for verification. Waste is sorted by DOT hazard class and placed in temporary containment bays by DOT class. Each bay is isolated to ensure segregation of incompatible waste types. All bays are equipped to contain any accidental spill. Shelving is also designed to absorb shaking from low-level seismic activity.

When enough individual items have been accumulated within a DOT class, the bar coded items are packaged for shipment into 5 to $55 \mathrm{gal}$ containers. Each container is also bar coded and moved to an adjoining storage building to await shipment to an offsite disposal facility. In this way, every waste item's location can be tracked from "cradle to grave." In 1997, 18,625 items were collected at the facility and a total of 2,347 waste containers were shipped for disposal.

The Solid and Hazardous Waste Management Department prepares weekly, monthly, and annual reports. Shipment of hazardous waste, carriers, receiving waste disposal facilities, and recycling facilities are documented in the Hazardous Waste Management Facility (HWMF) Annual Report and the Biennial Hazardous Waste Disposal Report submitted to NMED.

Table 3-3 presents a 5-year summary of waste handling activities at the HWMF. Table 3-4 details the waste categories received at the HWMF in 1997.

\section{Hazardous Waste Recycling}

In 1997, the HWMF received and redistributed $16,647 \mathrm{~kg}$ of lead to be reprocessed through the lead bank facility. The lead is recast and used for other applications at SNL/NM. Other categories recycled at the HWMF include PCBs, engine oil, various battery types, mercury compounds, and fluorescent and sodium lamps.

\section{Thermal Treatment Facility (TTF)}

The TTF is a small active component of the original Light Initiated High Explosives (LIHE) Facility. Small amounts of explosive wastes, generated from research and development experiments, are deactivated thermally. In 1997, $5 \mathrm{~kg}$ of residual explosive wastes were treated at the TTF. This represents only a small fraction of the explosive waste generated at SNL/NM; another $126 \mathrm{~kg}$ of explosive waste was treated at the KAFB Explosive Ordnance Disposal (EOD) site.

\subsubsection{Radioactive Waste Management}

Radioactive waste management is conducted in accordance with DOE Order 5820.2a, Radioactive Waste Management (DOE 1988a), and DOE Order 5400.5 Radiation Protection of the Public and the Environment (DOE 1993a). 
TABLE 3-3. Five-Year Summary of Waste Handling at the HWMF

\begin{tabular}{|c|c|c|c|c|c|c|}
\hline Year & $\begin{array}{l}\text { ER Wastes } \\
\text { (Soils etc.) } \\
\text { (kg) }\end{array}$ & $\begin{array}{l}\text { Routinely } \\
\text { Recycled } \\
\text { (kg) }\end{array}$ & $\begin{array}{l}\text { Non- } \\
\text { Routinely } \\
\text { Recycled } \\
(\mathrm{kg})\end{array}$ & $\begin{array}{l}\text { RCRA } \\
\text { (kg) }\end{array}$ & $\begin{array}{l}\text { Other } \\
\text { Hazardous } \\
\text { (kg) }\end{array}$ & $\begin{array}{l}\text { Total Waste } \\
\& \\
\text { Recyclables } \\
(\mathrm{kg})\end{array}$ \\
\hline 1997 & 344,334 & 15,227 & 73,121 & 50,153 & 231,011 & 713,846 \\
\hline 1996 & 5,517 & 14,082 & 81,027 & 51,549 & 181,405 & 333,580 \\
\hline 1995 & 303,966 & 46,806 & 67,484 & 91,876 & 287,729 & 797,861 \\
\hline 1994 & 541,090 & 18,220 & 24,794 & 102,545 & 140,408 & 827,057 \\
\hline 1993 & 144 & 9,095 & 17,356 & 140,613 & 316,406 & 483,614 \\
\hline
\end{tabular}

NOTE: *Routinely recycled materials include nickel-cadmium batteries and lead acid batteries. RCRA $=$ Resource Conservation and Recovery Act

$\mathrm{ER}=$ Environmental Restoration

TABLE 3-4. Breakdown of Hazardous Waste Handled by the HWMF in 1997

\begin{tabular}{|c|c|}
\hline HWMF Waste Categories & $\begin{array}{l}\text { Waste Shipped } \\
(\mathrm{kg})\end{array}$ \\
\hline \multicolumn{2}{|l|}{$\begin{array}{l}\text { Resource Conservation and Recovery Act } \\
\text { (RCRA) Waste (except ER) }\end{array}$} \\
\hline RCRA regulated waste & 49,564 \\
\hline $\begin{array}{l}\text { RCRA recycled waste (nickel-cadmium batteries, silver } \\
\text { compounds, mercury compounds, silver oxide batteries, } \\
\text { mercury batteries, and lamps) }\end{array}$ & 589 \\
\hline Total RCRA Waste & $\mathbf{5 0 , 1 5 3}$ \\
\hline \multicolumn{2}{|l|}{ Environmental Restoration (ER) Waste } \\
\hline RCRA & 343,290 \\
\hline Non-RCRA & 1,044 \\
\hline Total ER Waste & 344,334 \\
\hline \multicolumn{2}{|l|}{ Toxic Substances Control Act (TSCA) Waste } \\
\hline Asbestos & 155,951 \\
\hline Total Asbestos Waste & 155,951 \\
\hline Polychlorinated biphenyl (PCB) & 13,560 \\
\hline PCB recycled waste & 15,031 \\
\hline Total PCB Waste & 28,591 \\
\hline \multicolumn{2}{|l|}{ Biohazardous Waste } \\
\hline New Mexico special waste & 2,355 \\
\hline Total Biohazardous Waste & 2,355 \\
\hline \multicolumn{2}{|l|}{ "Other" Waste } \\
\hline Non-RCRA (chemical) & 16,398 \\
\hline RCRA Subtitle D (non-hazardous)* & 4,728 \\
\hline Recycled oil & 36,242 \\
\hline Recycled lead & 16,647 \\
\hline $\begin{array}{l}\text { Recycled (other) lead acid batteries, fluorescent lamps, } \\
\text { other oil, copper, batteries (nickel, metal hydride), and non- } \\
\text { PCB (ballasts, capacitors, and oils) }\end{array}$ & 58,447 \\
\hline Total "Other" Waste & 132,462 \\
\hline Total Waste Handled & 713,846 \\
\hline
\end{tabular}

NOTE: *Non-hazardous waste that does not meet waste acceptance criteria at the Solid Waste Transfer Facility (SWTF). 
There is no current state or federal law that regulates radioactive waste at $\mathrm{DOE}$ facilities. The hazardous component of mixed waste (MW), however, is regulated by RCRA (40 CFR 260-282).

In 1997, the Radioactive and Mixed Waste Management Facility (RMWMF) processed and shipped primarily low-level waste (LLW) and MW. Additionally, a small amount of transuranic (TRU) waste was received at the facility in 1997 (less than $0.5 \mathrm{~kg}$ ). Spent reactor fuel, generally considered a high level waste (HLW), is not considered a waste category by DOE since it is shipped offsite for reprocessing; therefore, SNL does not currently generate HLW. No offsite waste from other DOE installations was received at the facility in 1997. Table 3-5 presents a 5-year summary of waste handling activities at the RMWMF.

In addition to being a central collection point for radioactive waste, the RMWMF assists radioactive waste generators at SNL/NM in waste characterization, as needed. All waste received at the RMWMF is first verified. before being packaged and stored for later shipment. In 1997, LLW was shipped for permanent disposal to either EnvirocareTM in Utah or to the Nevada Test Site (NTS).

\section{Radioactive Waste Storage}

Presently, all newly generated radioactive waste is temporarily stored at three onsite locations: the RMWMF, the Manzano Bunkers, and the High Bay Waste Storage Facility (Bldg. 6596) in TA-V. There are approximately 221 cubic feet $\left(\mathrm{ft}^{3}\right)$ of TRU waste currently being stored at the Manzano Bunkers. TRU waste will ultimately be shipped to the Waste Isolation Pilot Plant (WIPP) in Carlsbad, New Mexico. WIPP is expected to begin accepting waste sometime in 1998. The Interim Storage Site (ISS) in TA-III is also set up to store waste, but is not being used at this time.

The bulk volume of the radioactive waste handled at the RMWMF in 1997 consisted of contaminated soils excavated from ER sites.
Other wastes sources are from Demolition and Decontamination (D\&D) projects and TA-V facilities where work is being done to convert two facilities that will be used in medical isotope production. Waste categories included personal protective equipment (PPE), general lab waste, and $D \& D$ waste. The primary radioisotope inventory contained in LLW waste handled at the RMWMF in 1997 included tritium, mixed fusion products, and isotopes of strontium, cobalt, cesium, thorium, and uranium. LLW also included low levels of plutonium and americium below the activity level designated for TRU waste. Less than $1.0 \mathrm{~kg}$ of actual TRU waste (plutonium and americium) was handled at the RMWMF in 1997.

\section{New Activities in 1997}

New procedures were written for the RMWMF in response to the "hot particle incident" last year. A very small hot particle (speck size) was discovered on the sorting room floor in August 1996. Due to inadequate health physics surveys, the particle remained undiscovered for 2 weeks. New survey and sorting procedures were developed or rewritten. Currently, all new waste accepted at the RMWMF is 100 percent verified.

\subsubsection{Mixed Waste (MW) Management}

The majority of MW now being stored onsite consists of very low level radioactive sludges from septic tank system close-outs, organic debris (mostly PPE), paper, plastic contaminated with radionuclides and solvents, and radioactive metallic objects contaminated with RCRA metals. The radioactive component in SNL/NM's current $\mathrm{MW}$ inventory results primarily from tritium, and isotopes of cesium, strontium, plutonium, americium, and uranium. The hazardous component results primarily from solvents, heavy metals, and toxic chemicals. Table 3-6 lists the current MW categories and the preferred treatment options. 
TABLE 3-5. Five-Year Summary of Radioactive Waste Handled at SNL/NM

\begin{tabular}{|c|c|c|c|c|c|}
\hline Year & $\begin{array}{l}\text { LLW } \\
\text { Generated } \\
\mathbf{k g}\left(\mathrm{ft}^{3}\right) \\
\end{array}$ & $\begin{array}{l}\text { LLW Shipped } \\
\mathrm{kg}\left(\mathrm{ft}^{3}\right)\end{array}$ & $\begin{array}{l}\text { MW } \\
\text { Generated } \\
\mathrm{kg}\left(\mathrm{ft}^{3}\right) \\
\end{array}$ & $\begin{array}{l}\text { MW Shipped } \\
\mathrm{kg}\left(\mathrm{ft}^{3}\right)\end{array}$ & $\begin{array}{l}\text { TRU Waste } \\
\text { Handled } \\
\mathrm{kg}\left(\mathrm{ft}^{3}\right)\end{array}$ \\
\hline 1997 & $\begin{array}{r}332,731 \mathrm{~kg} \\
\left(12,582 \mathrm{ft}^{3}\right)\end{array}$ & $\begin{array}{r}322,736 \mathrm{~kg}^{*} \\
\left(10,520 \mathrm{ft}^{3}\right)\end{array}$ & $\begin{array}{r}5,515 \mathrm{~kg}^{* *} \\
\left(284 \mathrm{ft}^{3}\right)\end{array}$ & 0 & $\begin{array}{r}0.45 \mathrm{~kg} \\
\left(0.12 \mathrm{ft}^{3}\right) \\
\end{array}$ \\
\hline 1996 & $\begin{array}{l}511,298 \mathrm{~kg} \\
\left(22,730 \mathrm{ft}^{3}\right)\end{array}$ & $\begin{array}{l}469,165 \mathrm{~kg} \\
\left(14,510 \mathrm{ft}^{3}\right)\end{array}$ & $\begin{array}{l}78,713 \mathrm{~kg} \\
\left(4,880 \mathrm{ft}^{3}\right)\end{array}$ & $\begin{array}{r}267 \mathrm{~kg} \\
\left(7 \mathrm{ft}^{3}\right)\end{array}$ & $\begin{array}{r}390 \mathrm{~kg} \\
\left(155 \mathrm{ft}^{3}\right)\end{array}$ \\
\hline 1995 & $\begin{array}{l}12,431 \mathrm{~kg} \\
\left(1,924 \mathrm{ft}^{3}\right)\end{array}$ & $\begin{array}{l}3,327 \mathrm{~kg} \\
\left(688 \mathrm{ft}^{3}\right)\end{array}$ & $\begin{array}{l}9,668 \mathrm{~kg} \\
\left(682 \mathrm{f}^{3}\right)\end{array}$ & 0 & $\begin{array}{r}3,789 \mathrm{~kg}^{\ddagger} \\
\left(170 \mathrm{ft}^{3}\right)\end{array}$ \\
\hline 1994 & $\begin{array}{r}\mathrm{NA} \\
\left(1886 \mathrm{ft}^{3}\right)\end{array}$ & 0 & $\begin{array}{r}N A \\
\left(59 \mathrm{ft}^{3}\right) \\
\end{array}$ & $\begin{array}{l}1,888 \mathrm{~kg} \\
\left(560 \mathrm{ft}^{3}\right) \\
\end{array}$ & 0 \\
\hline 1993 & $\begin{array}{r}\text { NA } \\
\left(1533 \mathrm{ft}^{3}\right)\end{array}$ & 0 & $\begin{array}{r}N A \\
\left(128 \mathrm{ft}^{3}\right) \\
\end{array}$ & 0 & $\begin{array}{r}5 \mathrm{~kg} \\
\mathrm{NA}\end{array}$ \\
\hline
\end{tabular}

NOTE: Both the mass and volume of waste are given where available. The waste programs report volume in cubic feet. $\mathrm{NA}=$ not available.

$\mathrm{LLW}=$ Low-level radioactive waste $\mathrm{MW}=$ Mixed waste $\mathrm{TRU}=$ Transuranic waste

* Approximately 80 percent of this quantity was from ER-contaminated soils $(-258,188 \mathrm{~kg})$.

** Amount includes weight of the MW containers. MW weight without containers was $1,978 \mathrm{~kg}$.

$\ddagger=$ All TRU waste came from the Inhalation Toxicology Research Institute (ITRI) in 1995.

\section{MW Part A and B Permit Status}

SNL/NM continues to operate under interim RCRA status with regard to MW management. Due to the previous lack of $M W$ treatment capacity, SNL/NM has been out of compliance with RCRA's maximum 1 year onsite storage rule. All RCRA waste must meet the Land Disposal Restrictions (LDRs) set forth in RCRA Section 3004j and treated to the standards described in "Section $\mathrm{m}$ " within 1 year of being generated.

In 1997, SNL/NM began onsite treatment of MW to resolve this compliance issue. Treatment of all existing $\mathrm{MW}$ at SNL/NM is scheduled to be completed by December 1998 .

\section{SNL/NM's Compliance History for MW}

SNL/NM's history leading up to the treatment and shipment of MW is described below.

1. MW became an issue after amendments to RCRA in 1984 enforced LDRs. MW inventory continued to accumulate onsite due to the national lack of treatment capacity needed to meet the LDRs.

2. In August 1990, SNL/NM submitted a RCRA Part A Interim Status Permit application for MW storage. Later revisions to the permit made various corrections and added new MW treatment processes.

3. On October 6, 1992, the FFCAct was passed requiring $\mathrm{DOE}$ to submit a site treatment plan for MW. The FFCAct made allowance for the storage of MW over the 1-year maximum, acknowledging the nation-wide lack of treatment capacity. Although noncompliance with RCRA continued to be an issue, DOE and SNL/NM remained in compliance with the FFCAct while treatment technologies were developed. The FFCAct was implemented by the NMED (20 NMAC 4.1) under the New Mexico Hazardous Waste Act.

4. On December 30, 1992, the EPA issued a Notice of Noncompliance (NON) for storage of RCRA-regulated waste (MW) over the 1-year maximum period.

5. In October 1993, DOE submitted to NMED a Conceptual Site Treatment Plan for Mixed Waste (SNL1993a); other drafts followed. 
TABLE 3-6. Mixed Waste Treatment Categories and the Current Preferred Treatment Options

\begin{tabular}{|l|l|l|l|}
\hline Category & $\begin{array}{l}\text { Estimated } \\
\text { FY97 Volume }\end{array}$ & Constituents & Preferred Treatment \\
\hline TG-1 & $1.86 \mathrm{~m}^{3}$ & Inorganic debris with explosive component & Deactivation \\
\hline TG-2 & $0.03 \mathrm{~m}^{3}$ & Inorganic debris with water reactive component & Deactivation \\
\hline TG-3 & $0.02 \mathrm{~m}^{3}$ & Reactive metals & Deactivation \\
\hline TG-4 & $0.14 \mathrm{~m}^{3}$ & Elemental lead & Macroencapsulation \\
\hline TG-5 & $0.05 \mathrm{~m}^{3}$ & Aqueous liquids & Neutralization, then stabilization \\
\hline TG-6 & $97 \mathrm{ml}^{3}$ & Elemental mercury & Amalgamation \\
\hline TG-7 & $0.2 \mathrm{~m}^{3}$ & Organic liquids I & Incineration \\
\hline TG-8 & $19.7 \mathrm{~m}^{3}$ & Organic debris with organic contaminants & Thermal desorption \\
\hline TG-9 & $9.6 \mathrm{~m}^{3}$ & Inorganic debris with TCLP metals & Macroencapsulation \\
\hline TG-10 & $3.7 \mathrm{~m}^{3}$ & Heterogeneous debris & Sorting of heterogeneous debris \\
\hline TG-11 & $3.6 \mathrm{~m}^{3}$ & Organic liquids II & Hydrothermal processing \\
\hline TG-12 & $1.4 \mathrm{~m}^{3}$ & Organic debris with TCLP metals & Macroencapsulation \\
\hline TG-13 & $0.02 \mathrm{~m}^{3}$ & Oxidizers & Deactivation, then stabilization \\
\hline TG-14 & $0.02 \mathrm{~m}^{3}$ & Aqueous liquids with organic contaminants & Evaporative oxidation \\
\hline TG-15 & $9.4 \mathrm{~m}^{3}$ & $\begin{array}{l}\text { Soils <50\% debris and particulates with TCLP } \\
\text { metals }\end{array}$ & Stabilization \\
\hline TG-16 & 0 & Cyanide waste & $\begin{array}{l}\text { Liquid/solid with organic and/or metal } \\
\text { contaminants }\end{array}$ \\
\hline TG-17 & $31.9 \mathrm{~m}^{3}$ & $\begin{array}{l}\text { Transuranic contaminants with hazardous } \\
\text { components }\end{array}$ & $\begin{array}{l}\text { Incineration, then stabilization } \\
\text { (Treatment technology in } \\
\text { development) }\end{array}$ \\
\hline $\begin{array}{l}\text { Mixed } \\
\text { TRU Waste }\end{array}$ & 0 &
\end{tabular}

NOTE: Treatment categories are detailed in the Mixed Waste Site Treatment Plan, Compliance Plan Volume (CPV) Background Volume (SNL 1998c).

TCLP $=$ Toxicity characteristic leaching procedure.

6. On March 31, 1995, DOE submitted its final Site Treatment Plan for Mixed Waste to NMED for SNL/NM waste (SNL 1995b).

7. In June 1995, the Historical Disposal Requests Validation (HDRV) Project was initiated to characterize legacy $\mathrm{MW}$ and to sort it into treatability groups. All MW generated through September 30, 1995 was sorted. The project also served to validate the treatment methods proposed on the RCRA permit application.

8. On October 6, 1995, the NMED issued a Compliance Order enforcing SNL/NM's Site Treatment Plan for Mixed Waste (SNL 1995b).

9. In November 1996, SNL resubmitted the Part A and B permit application, to reflect revisions to its proposed treatment methods
(Amendment 3). This remains the current permit application in effect.

10. In 1997, characterization related to the HDRV Project continued. Waste was staged and ready for shipment by the end of the year. At that time, the HDRV effort was discontinued and replaced with new sorting procedures.

11. In December 1997, onsite treatment of MW began at the RMWMF in Bldg. 6920. Additionally, Bldg. 6921 was converted to a laboratory for the treatment of certain types of MW. Procedures for the treatment of TG5, TG13, and TG15 were prepared and approved.

12. In January 1998, the Mixed Waste Site Treatment Plan, Compliance Plan Volume (CPV) Background Volume was updated to 
include the current treatment technologies and proposed schedules (SNL 1998c). The new plan also detailed storage areas, construction of treatment facilities, and transportation options to offsite disposal or treatment facilities.

13. In February $1998,18.5$ cubic meters $\left(\mathrm{m}^{3}\right)$ of waste was shipped to the Idaho National Engineering and Environmental Laboratories (INEEL) for incineration at their Waste Experimental Reduction Facility (WERF).

\section{Management for Newly Generated MW}

Currently, MW generators are required to complete a request form describing the proposed waste characteristics before generating MW. This practice ensures that waste can be properly characterized and sorted into the correct treatability groups. Process knowledge and direct sampling, as needed, is used to characterize the waste. By the summer of 1997 , newly-generated waste was being sorted into treatability groups upon arrival at the RMWMF.

\section{Treatment Technologies}

There are 11 onsite treatment processes described in the current RCRA permit application. The first five on the list are the most important treatments currently proposed:

- Deactivation

- Solidification/Stabilization

- Macroencapsulation

- Mechanical Processing

- pH Neutralization

- Amalgamation

- Chemical Oxidation

- Flocculation/Centrifugation

- Packed Bed Reactor/ Silent Discharge Plasma (PBR/SDP)

- Reverse Osmosis

- Thermal Desorption

MW is currently allowed to be managed at the Manzano Bunkers, the Interim Storage Site (ISS), the RMWMF, and the High Bay Storage
Facility in Bldg. 6596 as listed on the Part A and Part B RCRA permit.

SNL/NM continues to pursue several options for treating $\mathrm{MW}$ : onsite treatment, commercial offsite treatment, and treatment at DOE incinerators. Mobile treatment units, considered earlier and discussed in the 1995 ASER, will not be funded by DOE.

Deacitivation and stabilization/solidification are the two most important treatments being used at this time. The other primary treatments performed onsite are $\mathrm{pH}$ neutralization, macroencapsulation, and mechanical processing (physical sorting and separation). Macroencapsulation was demonstrated on some high activity reactor material. Due to the classified materials being handled, this process will be performed onsite starting in 1998 .

The only treatability study performed in 1997 was for treatment of TG15 type waste (soils). An important fact discovered through the characterization process was that much of the waste was not MW at all.

\section{SNL/CA Interface}

SNL/CA does not currently have an FFCAct Compliance Order in place and therefore cannot store MW for over 1 year. If SNL/CA cannot obtain a commercial treatment option, the waste may be shipped to SNL/NM before the 1 year deadline and managed under SNL/NM's FFCAct Compliance Order.

\subsubsection{Solid Waste Management}

SNL/NM's sanitary solid waste is regulated under RCRA Subtitle D and New Mexico's Solid Waste Management Regulations. Additionally, Executive Order (EO) 12780, Federal Agency Recycling, mandates the level of recycling expected from government agencies. 
The Solid Waste Transfer Facility (SWTF) screens, bales, stores, and ships solid waste and recyclables. All solid waste accepted at this facility is non-hazardous solid waste generated from offices and laboratories at SNL/NM. Some sanitary solid waste at SNL/NM is still collected and transported directly to landfills without special handling, as is the case for construction debris. Any hazardous waste received by the SWTF is remanifested to the HWMF.

\section{Paper and Cardboard Recycling}

The transfer station is the center for recycling paper and cardboard generated from SNL/NM and other cooperating outside agencies. Paper and cardboard are accepted from LANL, KAFB, and DOE field offices. KAFB joined SNL/NM's recycling effort in 1997.

Currently, only recyclable paper and cardboard are source segregated. Large piles of paper or cardboard are spread onto the floor and hand sorted as best as practical into quality levels. Paper is sorted by "White," "Office," and "Mixed" paper categories. Pure "white" paper is the highest quality and contains less than one percent non-white paper in the bales. "Office" paper may contain up to 30 percent mixed paper, and "Mixed" paper contains mostly colored paper, newspaper, and magazines. The recycled paper and cardboard bales are sold to recycling companies. Profits are split among the cooperating agencies.

Table 3-7 presents a summary of solid waste management in 1997. Table 3-8 details the amounts of recycled materials accepted from offsite agencies.

The SWTF works closely with Pollution Prevention and Waste Minimization Program staff to implement existing and new recycling activities.
TABLE 3-7. SWTF Activity Summary for 1997

\begin{tabular}{|c|c|c|c|}
\hline Category & $\begin{array}{l}\text { Weight } \\
\text { lb (kg) }\end{array}$ & $\begin{array}{c}\text { Volume } \\
\left(y d^{3}\right)\end{array}$ & $\begin{array}{l}\text { Bales } \\
\text { (each) }\end{array}$ \\
\hline $\begin{array}{l}\text { Total Solid } \\
\text { Waste }\end{array}$ & $\begin{array}{r}2,406,604 \mathrm{lb} \\
(1,091,617 \mathrm{~kg})\end{array}$ & $2,684.7$ & 1,413 \\
\hline \multicolumn{4}{|l|}{ Recyclables } \\
\hline White paper & $\begin{array}{r}747,416 \mathrm{lb} \\
(339,734 \mathrm{~kg})\end{array}$ & 953.8 & 502 \\
\hline Office paper & $\begin{array}{r}301,180 \mathrm{lb} \\
(136,900 \mathrm{~kg})\end{array}$ & 385.7 & 203 \\
\hline Mixed paper & $\begin{array}{r}56,292 \mathrm{lb} \\
(25,587 \mathrm{~kg})\end{array}$ & 70.3 & 37 \\
\hline Cardboard & $\begin{array}{r}317,034 \mathrm{lb} \\
(144,106 \mathrm{~kg})\end{array}$ & 463.6 & 244 \\
\hline Phọne books & $\begin{array}{r}26,000 \mathrm{lb} \\
(11,818 \mathrm{~kg})\end{array}$ & -- & - \\
\hline Wood pallets & $\begin{array}{r}7,000 \mathrm{lb} \\
(3,181 \mathrm{~kg})\end{array}$ & -- & - \\
\hline $\begin{array}{l}\text { Total } \\
\text { Recyclables }\end{array}$ & $\begin{array}{c}1,454,922 \mathrm{lb} \\
(661,328 \mathrm{~kg})\end{array}$ & $1,873.4$ & 986 \\
\hline
\end{tabular}

NOTE: The SWTF reports weight in pounds.

Conversions have been made to kilograms.

TABLE 3-8. Detailed Breakdown of Recyclable Materials Received From All Agencies

\begin{tabular}{|l|r|r|r|}
\hline Location & $\begin{array}{c}\text { Weight } \\
\text { (lb) }\end{array}$ & $\begin{array}{c}\text { Weight } \\
\text { (kg) }\end{array}$ & $\begin{array}{c}\text { Bales } \\
\text { (each) }\end{array}$ \\
\hline White Paper (up to 1\% non-white) \\
\hline SNL & 392,306 & 177,947 & 262 \\
\hline DOE & 38,680 & 17,554 & 25 \\
\hline LANL & 282,174 & 127,991 & 191 \\
\hline KAFB & 34,256 & 15,538 & 24 \\
\hline Office Paper (up to 30\% non-white) \\
\hline SNL & 16,090 & 7,298 & 11 \\
\hline DOE & 3,306 & 1,499 & 2 \\
\hline LANL & 281,784 & 127,815 & 190 \\
\hline Mixed Paper (mostly newspaper \& magazines) \\
\hline SNL & 8,748 & 3,968 & 6 \\
\hline LANL & 47,544 & 21,565 & 31 \\
\hline Cardboard & \multicolumn{4}{|c|}{} \\
\hline SNL & 300,138 & 136,140 & 232 \\
\hline DOE & 1,684 & 763 & 1 \\
\hline LANL & 1,756 & 796 & 1 \\
\hline KAFB & 13,456 & 6,103 & 10 \\
\hline Total & $1,421,922$ & 644,977 & 886 \\
\hline
\end{tabular}




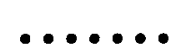

\subsubsection{The Asbestos Program}

Asbestos is regulated under the Toxic Substances Control Act (TSCA) and implemented by 40 CFR 763. Asbestos is also regulated as a hazardous air pollutant under NESHAP 40 CFR 61, Subpart M.

At SNL/NM, the abatement of asbestoscontaining equipment and building materials is ongoing. However, asbestos removal is only performed if the material presents an inhalation hazard, or if the building is to be torn down or renovated. Typical building materials containing asbestos include floor and ceiling tiles, certain types of insulation, and other fire retardant construction materials. Similarly, in instances where laboratory equipment has asbestos-containing material in a non-friable form and there is no risk of particle inhalation, the item is allowed to remain in service or is redistributed through the property reapplication program. The typical asbestos waste generated from equipment abatement consists of gloves, fume hoods, cable insulations, and ovens.

The Facilities Department is responsible for the removal and waste packaging of asbestos waste generated from old building materials (SNL 1991c). All other asbestos waste is managed by the Solid and Hazardous Waste Department. All asbestos waste is stored at the HWMF in temporary buildings (located within an adjoining compound) where TSCA-regulated, biohazard, and other miscellaneous waste items are temporarily stored until shipment. Larger asbestos-contaminated items may be stored at the maintenance yard located across from the HWMF. Asbestos waste is generally shipped offsite within a few days or weeks of being received. Disposal is at a New Mexico landfill permitted to accept friable asbestos waste. In $1997,155,951 \mathrm{~kg}$ of asbestos waste was shipped for disposal. This was $78,630 \mathrm{~kg}$ more than was shipped in 1996. Program information is described in the Asbestos Waste Operations Management Program (SNL 1995e).

\subsubsection{The Polychlorinated Biphenals (PCB) Program}

PCBs are regulated under TSCA and implemented by 40 CFR 761. Materials having a $\mathrm{PCB}$ concentration equal to or greater than 500 ppm are defined as PCBs; materials with a PCB concentration greater than or equal to $50 \mathrm{ppm}$ but less than $500 \mathrm{ppm}$ are defined as "PCBcontaminated." Non-PCBs-as defined by EPA - are materials with less than $50 \mathrm{ppm}$ of PCBs.

SNL/NM's PCB Program is progressing to reduce the level of $\mathrm{PCB}$ and $\mathrm{PCB}$-contaminated equipment to the greatest extent possible. Items affected by the program are primarily transformers, capacitors, switches, and fluorescent light ballasts (the largest $\mathrm{PCB}$ waste source). Other substances that may be PCBcontaminated include dielectric fluids, contaminated solvents, hydraulic oils, waste oils, heat transfer liquids, lubricants, paints, and casting wax. There is currently only one transformer left; it will be removed in 1998. Items that are suspected to contain PCBs but remain sealed (and would otherwise need to be destructively tested) are allowed to remain in service.

Like other TSCA waste, PCB waste is handled by the HWMF and stored within the adjoining fenced compound. In 1997, 28,591 kg of PCB waste was shipped offsite. (This was $23,465 \mathrm{~kg}$ less than was shipped in 1996.)

“Out, out damn spot!" [Lady Macbeth, Shakespeare] A new program activity to remove $\mathrm{PCB}$ oil stains from concrete was initiated in 1997. PCB contamination is very difficult to remove from porous concrete since normal surface cleaning only brings up more PCBs from deeper layers within the material. Thus far, the 
decontamination trials have had limited success. New methods will continue to be tested.

The SNL/NM PCB Program produces an annual report by July lst of the following reporting year detailing its activities, as required by TSCA. Program information is described in the P.CB Program (PG) document (SNL 1995c).

\section{$\begin{array}{ll}3 & \text { WASTE MINIMIZATION AND } \\ \text { POLLUTION PREVENTION } \\ \text { (P2) PROGRAMS }\end{array}$}

\subsubsection{P2 Program Scope}

The P2 Program has been developed to infuse pollution prevention practices into SNL/NM's corporate culture by encouraging and enabling practices that reduce or eliminate waste sources, improve process efficiency, facilitate reapplication or recycling of potential waste items, and procure products with recycled content, wherever feasible. The P2 Program is concerned with all waste streams. Program drivers are listed in table 3-9.

The P2 Program supports SNL/NM's line organizations by providing background research on waste reduction technologies and products, performing cost-benefit analyses, and helping to locate and obtain P2 funding. The P2 Program works in concert with waste generator liaisons, ES\&H coordinators, and a team of P2 line representatives.

SNL/NM's P2 efforts received recognition in several areas for excellent performance in 1997:

- DOE Certificate of Merit DOE/Albuquerque Operations Office (DOE/AL) Team Quality Award

- Honorable Mention DOE P2 - Motor Pool

- Water Conservation Award - Federal Energy Management Program

- Solid Waste Transfer Facility (SWTF) Honorable Mention, DOE P2 Award

\subsubsection{Generator Set-Aside Fee (GSAF) Program}

The GSAF Program was created to provide a direct incentive for waste generating organizations to minimize their waste. The program is part of a DOE pilot program to set aside funds for $\mathrm{P} 2$ activities by collecting a small fee from waste generators. The fees are used to fund other P2 activities at SNL/NM. In $1997, \$ 256,000$ in GSAF funds were used toward eight P2 projects, some of which are ongoing. These projects are described briefly below.

- X-Ray Fluorescent Plating Bath Replacing wet chemical titration methods with an X-ray fluorescent source for use in analyzing plating bath solutions at the Neutron Generator Facility (NGF). This will eliminate the generation of approximately $1,886 \mathrm{~kg}$ of hazardous waste per year.

- Steam Plant Optimization - Implemented several new processes to improve fuel efficiency and reduce emissions at the Steam Plant. Processes involved reprogramming the boiler control operations and tuning the overall system to optimize boiler operations. The new settings are anticipated to reduce air pollutant emissions by 60.1 tons per year (tpy).

Cooling Tower Efficiency - Conducted a pilot study to investigate potential modifications on 23 building system cooling towers. The goal is to reduce water consumption. Changes would likely include modifying the current chemical treatment system and installing instrumentation to maximize cooling performance. This project is expected to reduce water usage by 20 million gallons per year. 
TABLE 3-9. Drivers for Pollution Prevention and Waste Minimization Programs

\begin{tabular}{|l|l|l|}
\hline Regulation & Title or Description & Regulator/Agency \\
\hline RCRA Section 6002 & Federal Procurement & EPA \\
\hline EO 12856 & $\begin{array}{l}\text { Federal Agency Compliance with Right-to-Know Laws and Pollution } \\
\text { Prevention Requirements }\end{array}$ & Executive Office \\
\hline EO 12902 & Energy Efficiency and Water Conservation at Federal Facilities & Executive Office \\
\hline EO 12873 & Federal Acquisition, Recycling, and Waste Prevention & Executive Office \\
\hline 42 USC 13102 & Pollution Prevention Act of 1990 & EPA \\
\hline
\end{tabular}

NOTE: RCRA = Resource Conservation and Recovery Act. $\mathrm{EPA}=$ Environmental Protection Agency.

- Slurry-Free Polish Pad - Developing a polishing pad system for the Microelectronics Development Laboratory (MDL) semiconductor fabrication process. The improved system will eliminate the purchase of liquid slurry resulting in a reduction of approximately $4,750 \mathrm{~kg}$ of slurry waste and $30 \mathrm{~kg}$ of contaminated pads per year.

- Installation of Microbial Parts Cleaner Installing a microbial parts cleaner at Bldg. 981. This system, which will clean small metal parts, effectively removes oil and grease using microbes as part of the cleaning process. The system will eliminate approximately $600 \mathrm{~kg}$ of hazardous waste per year.

- Reuse of Wastewater for Irrigation Evaluating the engineering aspects on how to capture wastewater from cooling towers and other "gray" water for use as irrigation at KAFB. The proposed system would consist of a holding tank and distribution system and would recycle approximately 90 million gallons of wastewater per year.

- Modification of Wet Chemistry Process Benches - Modifying piping systems at several wet chemical benches at the Microelectronic Development Laboratory (MDL). The new systems will separate rinse tank from process tank discharges, allowing rinse tank wastewater to be treated and reused. The modifications will reduce water consumption by $9,000 \mathrm{gal} / \mathrm{day}$.

- Mini Reactor Vessel - Replaced a large reactor vessel with a $300-\mathrm{ml}$ mini reactor vessel. The reactor vessel is used to perform studies in the area of material liquification of lingin. The research is part of DOE's Ethanol Fuel Program. The smaller vessel will reduce the quantity of chemical reagents needed and the quantity of hazardous waste generated. The replacement will result in a reduction of approximately $800 \mathrm{~kg}$ per year of hazardous waste.

\subsubsection{Pollution Prevention Opportunity Assessments (PPOAs)}

PPOAs are performed to discover potential opportunities to reduce waste generated from various SNL projects through:

- Improving process efficiency,

- Substituting chemicals,

- Controlling chemical inventory,

- Improving preventive maintenance, and

- Saving energy.

\section{Environmental Restoration ER Sites}

Formal PPOAs were conducted at three ER sites in March 1997: the Classified Waste Landfill (ER Site 2) and two at the Moonlight Shot Area (ER Sites 68 and 71). The P2 Program made 
several overall recommendations for these sites. The primary recommendation was to use a Segmented Gate System (SGS) for processing radioactively contaminated soils at ER sites. The SGS would physically screen and separate out the radioactive component in contaminated soils and reduce the volume of LLW generated. Other suggestions for onsite work included using launderable PPE instead of disposal PPE, reusing respirator cartridges, and using ER salvage metals to fabricate usable waste containers. Incorporating $\mathrm{P} 2$ processes and language into $\mathrm{ER}$ project plans and contract documents was also suggested.

As a result of the PPOAs conducted for ER activities, five P2 opportunities were proposed as Return-on-Investment (ROI) projects and submitted to DOE in April 1997. Three proposals were funded; these projects are discussed in detail in section 3.3.4.

\section{Demolition and Decontamination (D\&D)}

In April 1997, the P2 Team conducted a PPOA for D\&D activities at Bldg. 906. However, since the D\&D was about 75 percent complete at the time of the PPOA, the assessment was used as a pilot project to evaluate future $D \& D$ projects. Recommended P2 opportunities included reusing and crushing concrete; recycling "free release" materials (surveyed and determined to be free of radiological contamination); reusing respirator cartridges; recycling and reusing lead; and recycling, laundering, or reusing PPE and tarp, whenever possible.

\subsubsection{Return-on-Investment (ROI) Projects}

The P2 Program has received ROI funding from DOE for proposed projects that will return the initial investment cost within 2 years of implementation through various cost-saving mechanisms. The P2 Program proposed five ROI projects in 1997 that were approved by DOE:
- Recycle Operations with LANL - Purchased roll-off containers and modified a truck for roll-off transport for recyclables picked up from LANL.

- Solvent Substitution - Conducting studies for replacing solvents used in weapon maintenance to reduce or eliminate hazardous waste and MW. This is a joint effort between LANL, Lawrence Livermore National Laboratory (LLNL), and DOE's Kansas City facility. If successful, this will eliminate approximately $1,370 \mathrm{~m}^{3}$ of $\mathrm{MW}$ and $457 \mathrm{~m}^{3}$ of hazardous waste per year.

- Compactor for ER Waste - Obtained surplus waste compactor from SNL/CA for ER remediation activities at Site \#1. Typical ER waste includes gloves, booties, Tyvek ${ }^{\mathrm{TM}}$ suits, and other compactible materials. Reduced waste volume will result in lower waste management costs.

- Segmented Gate System (SGS) - Leased a SGS to screen ER radioactive soils. The system will reduce the total volume of waste by at least 80 percent. This is equivalent to a reduction of approximately $608 \mathrm{~m}^{3}$ of LLW.

- Launderable PPE for Radiological Protection - Purchased launderable PPE for TA-V and ER operations. The new PPE will be laundered offsite and reused up to 100 times. This will eliminate approximately $7,300 \mathrm{~kg}$ of radioactive waste per year.

\subsubsection{Recycling and Waste Minimization}

SNL/NM is continuing to work on improvement and expansion of its recycling program. Current materials recycled include paper, cardboard, oil, metals, tires, construction materials, office products, and various other categories. Implementation of recycling programs is 
through the waste management groups. Table 3-10 lists the categories and amounts of waste recycled by SNL/NM in 1997.

Other recycling and waste minimization efforts conducted in 1997 at SNL/NM include the following:

- Chemical Exchange Program - In 1997, 45 different types of chemicals with an estimated value of $\$ 10,000$ were shipped to the Ohio State Groundwater Research Laboratory. The chemicals will be used for groundwater sample testing.

- Lead Bank - Lead shielding and other lead materials are collected for reapplication and recasting. In 1997, approximately 13,600 $\mathrm{kg}$ of lead was reapplied.

- Radioactive Source Bank - SNL/NM is developing a radioactive source bank that will be fully implemented by September 1998. Radioactive materials will be collected for reuse and recycling, where possible.

- "Green" Landscaping Practices SNL/NM conserves water and reduces pesticide and herbicide use by landscaping with drought-tolerant plants and using gravel covers (xeriscape). Landscape waste is recycled through mulching and composting, where feasible.

- Affirmative Procurement - Affirmative procurement is the purchase of products made from recycled materials. In 1997, SNL/NM's recycled purchases included construction materials, vehicle products, landscape products, park and recreation products, paper products, and non-paper office products.

- Cooperative Recycling - Because of SNL's capability to process and market material, SNL/NM has joined with LANL, DOE/AL, and $\mathrm{KAFB}$ on cooperative agreements for recycling materials. Profits from the resale of recyclable paper and cardboard are shared between the facilities. Joint plans for future recycling will include plastics, metals, and other types of paper.

TABLE 3-10. Categories of Waste Recycled at SNL/NM in 1997

\begin{tabular}{|c|c|}
\hline Recycled Categories & Weight (kg) \\
\hline Stainless steel & 14,930 \\
\hline Copper & 71,130 \\
\hline Iron & 353,17 \\
\hline Aluminum metal & 51,130 \\
\hline Lead & 16,647 \\
\hline Gold & \\
\hline Engine oils & 74,580 \\
\hline Toner cartridges & 4,370 \\
\hline Batteries & 14,850 \\
\hline Tires & 8,690 \\
\hline Food waste & 1,180 \\
\hline Wood. & 351,010 \\
\hline Mercury items & 15 \\
\hline PCB items & 26,860 \\
\hline $\begin{array}{l}\text { Chemical Exchange Program } \\
\text { chemicals }\end{array}$ & 1 \\
\hline Fluorescent light bulbs & 7,900 \\
\hline Non-PCB light ballasts & 1,53 \\
\hline Office paper & 224,000 \\
\hline Cardboard & 143,000 \\
\hline Phone books & 9,830 \\
\hline Aluminum cans & 22,910 \\
\hline Other chemicals & 1,080 \\
\hline Other scrap metal & 45,000 \\
\hline Total & $1,442,987$ \\
\hline
\end{tabular}

SNL/NM has developed plans to prevent the release of oil, toxic, and hazardous materials from any potential container leak or unplanned release from all laboratory processes utilizing hazardous and/or toxic materials. These plans address prevention, control, reporting, and cleanup procedures. Chemicals stored or used onsite and requiring special spill containment procedures include acids, bases, solvents, waterbased chemicals, and oil. 
TABLE 3-11. Important Documents for Waste Management Programs

\begin{tabular}{|c|c|}
\hline Waste Management Program Documents & Reference \\
\hline Waste Management $(\mathrm{PG})$ & SNL 1997b \\
\hline Programmatic Waste Acceptance Criteria & SNL 1996c \\
\hline \multicolumn{2}{|l|}{ Hazardous Waste } \\
\hline Hazardous Waste Management Facility Annual Reports & (no reference) \\
\hline Hazardous Waste Management Facility Monthly Reports & (no reference) \\
\hline Biennial Hazardous Waste Report & (no reference) \\
\hline Chemical Waste Management (PG) & SNL 1996e \\
\hline Medical Waste (PG) & SNL 1996d \\
\hline Explosive Waste Program (PG) & SNL $1995 \mathrm{f}$ \\
\hline Section 10E- "Chemical Spills," from the ES\&H Manual & SNL 1998h \\
\hline Section 19A-"Hazardous Waste Management," from the ES\&H Manual & SNL 1998d \\
\hline \multicolumn{2}{|l|}{ Radioactive Waste } \\
\hline Site Treatment Plan for Mixed Waste, Sandia National Laboratories, New Mexico & SNL 1995b \\
\hline $\begin{array}{l}\text { Section 19B- "Low-Level Radioactive Waste Management," from the } E S \& H \\
\text { Manual }\end{array}$ & SNL 1998e \\
\hline Section 19C- "Mixed Waste Management," from the ES\&H Manual & SNL 1998f \\
\hline $\begin{array}{l}\text { Section 19D- "Radioactive Material Management Areas (RMMAs)," from the } \\
\text { ES\&H Manual }\end{array}$ & SNL 1998g \\
\hline $\begin{array}{l}\text { Mixed Waste Site Treatment Plan, Compliance Plan Volume (CPV) Background } \\
\text { Volume }\end{array}$ & SNL 1998c \\
\hline Radioactive and Mixed Waste (PG) & SNL 1991a \\
\hline \multicolumn{2}{|l|}{ TSCA Waste } \\
\hline$P C B$ Inventory and Waste Disposal Program (PG) & SNL 1995c \\
\hline PCB Annual Report & (no reference) \\
\hline PCB Annual Document Log & (no reference) \\
\hline Facilities Asbestos Management (PG) & \begin{tabular}{|l|l} 
SNL 1991c \\
\end{tabular} \\
\hline Asbestos Waste Operations Management Program (PG) & SNL 1995e \\
\hline \multicolumn{2}{|l|}{ Solid Waste } \\
\hline Annual Solid Waste Reports & (no reference) \\
\hline Solid Waste Program $(\mathrm{PG})$ & SNL 1995g \\
\hline \multicolumn{2}{|l|}{ Waste Minimization and Pollution Prevention } \\
\hline Pollution Prevention (PG) & SNL 1991d \\
\hline Pollution Prevention Plan & SNL 1997c \\
\hline Annual Report on Waste Generation and Waste Minimization Progress & (no reference) \\
\hline
\end{tabular}

NOTE: PG denotes a "Program Document," which is a specific type of ES\&H document. 
Oil Spill Containment

SNL/NM follows an Oil Spill Prevention Control and Countermeasures Plan (SPCC) (CDM 1995) in accordance with 40 CFR 112, "Oil Pollution Prevention." The plan outlines practices to prevent the discharge of oil from reaching any navigable waters of the United States or tributaries of such waters. The plan specifically identifies the requirements for oil storage and secondary containment around transformer pads, oil tanks, and other oil containment equipment and facility locations.

As of December 1997, there was a total of $3,604,419$ gal of oil stored onsite at 94 aboveground locations. Locations are recorded based on a minimum storage of $660 \mathrm{gal}$ per site. Most of these sites are provided with secondary spill containments, such as concrete lined basins, retaining walls, containment reservoirs, earthen berms, sloped pads, and trenches. The annual SPCC oil storage facilities inspection reports for SNL/NM's oil storage locations are compiled by the Environmental and Emergency Management Department.

\section{Chemical Spill Containment}

Spill containments must also be provided in areas where toxic and hazardous materials are stored or are routinely used. Basic requirements are contained in 40 CFR 302, Designations, Reportable Quantities (RQs) and Notifications, 40 CFR 355, Emergency Planning and Notification, 40 CFR 370, Hazardous Chemical Reporting, and 40 CFR 372, Toxic Chemical Release Reporting: Community Right-to-Know. DOE Order 232.1a (DOE 1997c) outlines occurrence reporting requirements.

Chapter 10, Section E, of the ES\&H Manual, "Chemical Spills," documents general safety procedures for areas where chemicals are used or stored, including proper containments (SNL 1998h). All organizations that have a potential for chemical spills are required to have appropriate spill response equipment available at the site of chemical storage and use. MSDS information is also readily available wherever chemicals are handled or stored. Spill equipment may include PPEs, absorbents, neutralizers, plastic buckets with lids, heavy plastic bags, trays or shovels, and brooms. The ES\&H Manual documents chemical containment and labeling requirements and the correct procedure for handling and disposing of any chemical spills (SNL 1998d, SNL 1995d).

\subsection{UNDERGROUND STORAGE}

USTs at SNL/NM are regulated by the NMED UST Bureau under 20 NMAC 5. In 1990, the State of New Mexico adopted federal standards contained in RCRA Subpart I, and implemented under 40 CFR 280, "Underground Storage Tanks." The EPA transferred authority to the State in accordance with 40 CFR 281, "Approval of State UST Programs." UST regulations that will become effective in 1998 will require higher standards for tank components. This will include more rigorous spill, overfill, and corrosion standards. Currently, two tanks at SNL/NM do not meet these stricter requirements. Both of these tanks (Bldgs. 6523 and 983) will be closed during 1998.

SNL/NM's five USTs have a combined volume of 58,230 gal:

- 20,000-gallon UST (oil storage)

at Bldg. 888 ( 1 of 2)

- 20,000-gallon UST (oil storage)

at Bldg. 888 (2 of 2)

- 9,730-gallon UST (emergency generator fuel) at Bldg. 862

- 7,000-gallon UST (hydraulic oil storage for Outdoor Centrifuge Facility) at Bldg. 6523

- 1,500-gallon UST (ethylene glycol) at Bldg. 983

\section{UST Status}

On June 12, 1997, the UST Bureau issued a Field Notice of Violation to DOE/KAO and SNL/NM for failure to register a UST system at Bldg. 9939. The UST, which had been previously 
unregistered, was closed and a No Further Assessment (NFA) determination from the Bureau was completed in August 1997. One additional UST was discovered and registered in September 1997 (BIdg. 6523). These incidents prompted SNL/NM to perform a thorough examination of all its facilities to determine if other unregistered USTs existed. In February 1998, one additional UST at Bldg. 983 was reviewed by the UST Bureau and found to require registration. $A$ thorough and diligent search at SNL/NM facilities did not uncover any additional USTs requiring registration.

Requirements for SNL/NM's UST program management are described in the ES\&H Manual (SNL 1998k).

\section{NATIONAL ENVIRONMENTAL POLICY ACT (NEPA) COMPLIANCE ACTIVITIES}

The National Environmental Policy Act (NEPA) of 1969 is the nation's most comprehensive legislative and public policy statement on protection of the environment. It requires that the federal agencies consider every potentially significant aspect of the environmental impacts that may result from proposed actions. NEPA also requires federal agencies to inform the public during the decision-making process.

\section{SNL/NM's NEPA Program}

SNL/NM's Environmental and Emergency Management Department implements the NEPA Program under the direction of DOE/KAO. Although only DOE has the authority to decide the appropriate level of NEPA documentation required, SNL/NM assists $\mathrm{DOE}$ by drafting proposed documentation for DOE approval. NEPA documents completed in 1997 are listed in section 2.1.5. NEPA guidance is available in the ES\&H Manual (SNL 1997j) and the associated program document, NEPA (SNL 1991b).
NEPA documents are prepared for any project posing potentially significant impacts to the environment. The process usually begins with the preparation of an Environmental Checklists/Action Description Memorandum (ECL/ADM). In most cases, no further documentation will be required; however, if significant potential impacts are likely, an Environmental Assessment (EA) or an Environmental Impact Statement (EIS) will be required. Most EAs prepared by SNL/NM result in a Finding of No Significant Impact (FONSI).

\section{DOE's NEPA Regulations}

In 1996, DOE amended 10 CFR 1021, "National Environmental Policy Act," to incorporate changes to improve DOE's efficiency and cost effectiveness in implementing NEPA requirements. DOE Order 451.1, NEPA (DOE 1997d), issued on September 11, 1995, establishes responsibilities and procedures to implement NEPA in conformance with DOE NEPA regulations. Other drivers for the program are contained within the DOE Secretary's NEPA Notice of February 5, 1990 (DOE 1990b) and the Secretary's Policy Statement on NEPA made in June 1994 (DOE 1994a).

SNL/NM Site-Wide Environmental Impact Statement (SWEIS)

In 1997, the DOE announced its intent to prepare a SWEIS for SNL/NM. As a matter of policy, the DOE prepares such NEPA documents for its large, multi-facility installations. The existing site-wide document, published in May 1977, is titled Environmental Impact Assessment, Sandia Laboratories, Albuquerque, New Mexico (ERDA 1977). At that time, NEPA regulation specifying the requirements of an Environmental Impact Statement had not yet been promulgated. The Energy Research and Development Administration (ERDA) was the agency predating the DOE. Since that time, other NEPA documents have been prepared for specific projects at SNL/NM, including one EIS and various EAs. The new SWEIS will address 
operations and activities that DOE foresees at SNL/NM for approximately the next 10 years. The USAF will participate as a cooperating agency.

The SWEIS will provide an overall NEPA baseline for comparison of current environmental conditions with the effects of proposed future projects and activities. The SWEIS will also enable DOE to "tier" its NEPA documents so as to eliminate repetitive discussion of the same issues in future projectspecific NEPA studies, and to focus on the actual issues ready for decisions at each level of environmental review.

The public scoping period for the new SWEIS began with a notice published in the Federal Register on May 30, 1997. The purpose of this notice was to invite public participation in the process and to encourage public dialogue on alternatives that should be considered. The public comment period was closed on July 14, 1997.

SNL/NM will participate in the development of the SWEIS, including being a part of "key parameter teams." These teams involve experts from DOE, SNL, and the contracted agency preparing the SWEIS. The teams will assist in scoping the SWEIS and carrying out the required analysis. The DOE plans to release the draft EIS for public comment in early September 1998. Once the draft EIS is released, the public will have a 45-day period in which to submit any comments.

The SNL/NM SWEIS will:

- Assess impacts from current and planned activities;
- Describe the natural and social environment affected by laboratory operations; and

- Present the impacts from several alternatives that cover the full range of operations that the DOE foresees for SNL/NM.

The issues listed below have been identified for analysis in this SWEIS as being applicable to the operation of SNL/NM:

- Potential effects on the public and workers from exposures to radiological and hazardous materials during normal operations and from reasonably postulated accidents, including aircraft crashes

- Potential effects on air and groundwater quality from normal operations and potential accidents

- Potential cumulative effects of past, present, and future operations at SNL/NM; the SWEIS will include effects of current and reasonably foreseeable federal actions on KAFB

- Effects on waste management practices and activities, including pollution prevention, waste minimization, and waste stream characterization

- Potential impacts of noise levels to the ambient environment and sensitive receptors

- Potential impacts on land use plans, policies, and controls 


\section{TERRESTRIAL \\ Surveillance Program}

$\mathrm{T}$ The two major activities comprising environmental monitoring are environmental surveillance and effluent monitoring. The purpose of environmental surveillance is to measure ambient levels of pollutants in the environment and assess changes over time as compared to baseline or "natural" conditions. This chapter discusses that part of environmental surveillance that concerns terrestrial surface media. Other environmental surveillance programs have been developed for ambient air and groundwater and are discussed in chapters 5 and 7.

\section{1 \\ PROGRAM BACKGROUND}

Annual terrestrial surveillance sampling is performed by SNL/NM's Environmental and Emergency Management Department to identify and characterize levels of contaminants in the environment in and around SNL/NM's operational areas.

\section{Program Objectives}

Terrestrial Surveillance Program objectives are summarized in the following excerpts based on requirements given in DOE Order 5400.1, General Environmental Protection Program, (DOE 1990a):

- Collect and analyze samples so as to characterize environmental conditions and define increasing or decreasing trends.

- Establish background levels of pollutants to define baseline conditions.
- Provide a continuing assessment of pollution abatement programs.

- Identify and quantify new or existing environmental quality problems and their potential impacts, if any.

- Verify compliance with applicable environmental laws and regulations and commitments made in National Environmental Policy Act (NEPA) or other official documents.

Terrestrial surveillance activities include the collection of terrestrial media (soil, sediment, vegetation, and surface water) and the examination of raw data and statistical analyses to determine impacts, if any, to the environment. Samples are collected within and near SNL/NM's five technical areas and in remote test areas. Offsite samples are collected from up to a 25-mile radius of SNL/NM's facilities for comparisons.

The DOE Oversight Bureau of the New Mexico Environment Department (NMED) periodically splits samples with SNL/NM for an additional level of verification. These comparison results are available from the Bureau upon request.

\section{Sample Analysis}

Sample analysis includes radiological and nonradiological parameters, providing a broad base of analytes to characterize environmental conditions.

Nonradionuclide contaminant levels in samples are compared to standards where they exist, such as proposed RCRA action levels for soils 
and 40 CFR 143.3, "Secondary Maximum Contaminant Levels." Soil and sediment sample results are also compared to U.S. surface soil averages (CRC 1992) and local background measurements taken in areas where "natural" conditions are present.

There are no set state or federal regulatory standards for radiological contaminants in soil. Standards and requirements for radionuclide levels are given in DOE Order 5400.5, Radiation Protection of the Public and the Environment (DOE 1993a). In addition to radiological analysis of terrestrial media, SNL/NM measures ambient levels of gamma radiation (from both man-made and natural sources) quarterly.

\section{Discovering Trends}

Statistical analysis is performed on data to ascertain if trends are present, indicating either decreasing or increasing contaminant levels at a site. Annual data results are compared between locations as well as comparing current and past results at each site. In this way it can be determined if statistically significant differences exist. Most importantly, statistical analysis is used to determine if elevated levels are caused by SNL/NM operations and, if so, to recommend or initiate further investigation and mitigation measures.

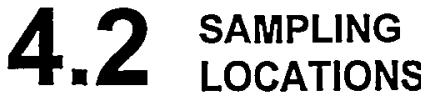

Terrestrial sampling in 1997 was performed in July at 72 fixed locations. Fixed locations remain relatively constant from year to year to provide a basis for statistical comparisons. New locations, however, are added as necessary to reflect ongoing activities such as new facility start-ups, environmental remediation activities, and new sites of contaminant discovery. Conversely, some locations may be removed from the survey in conformance with current program objectives or to allow resources for new locations to be established in areas that are potentially more relevant. Other considerations that support the determination of an optimum sampling site include topography, wind direction, and the proximity to existing sampling sites (so as to reduce redundant data). No new sites were added in 1997. Sampling locations are located in three distinct areas:

- Onsite locations are sited within areas of past or present SNL/NM operations. Sampling locations are located either in areas of known or potential contamination, for example, near Environmental Restoration (ER) sites, reactor facilities, and landfills, or in areas where samples would likely provide a representative profile of the general pollutant accumulation from SNL/NM facilities as a whole. There are currently 39 onsite locations.

- Perimeter locations are sited within close proximity of SNL/NM operational areas on and off of KAFB. Perimeter locations are used to establish if contaminants are migrating to or from SNL/NM site operational areas. There are currently 17 perimeter locations.

- Offsite locations are chosen in areas where little, if any, contamination from any source is expected, and far enough away from SNL/NM operations that any contamination present cannot be SNL-derived. This provides a "clean environment" baseline from which SNL staff can statistically compare onsite and perimeter data. There are currently 16 offsite locations. Nine of these locations are strictly thermoluminescent dosimeter (TLD) monitoring stations.

Figure 4-1 illustrates onsite and perimeter sampling locations. Tables 4-1 and 4-2 lists onsite and perimeter locations, respectively, and the media that were collected from each site in 1997. 


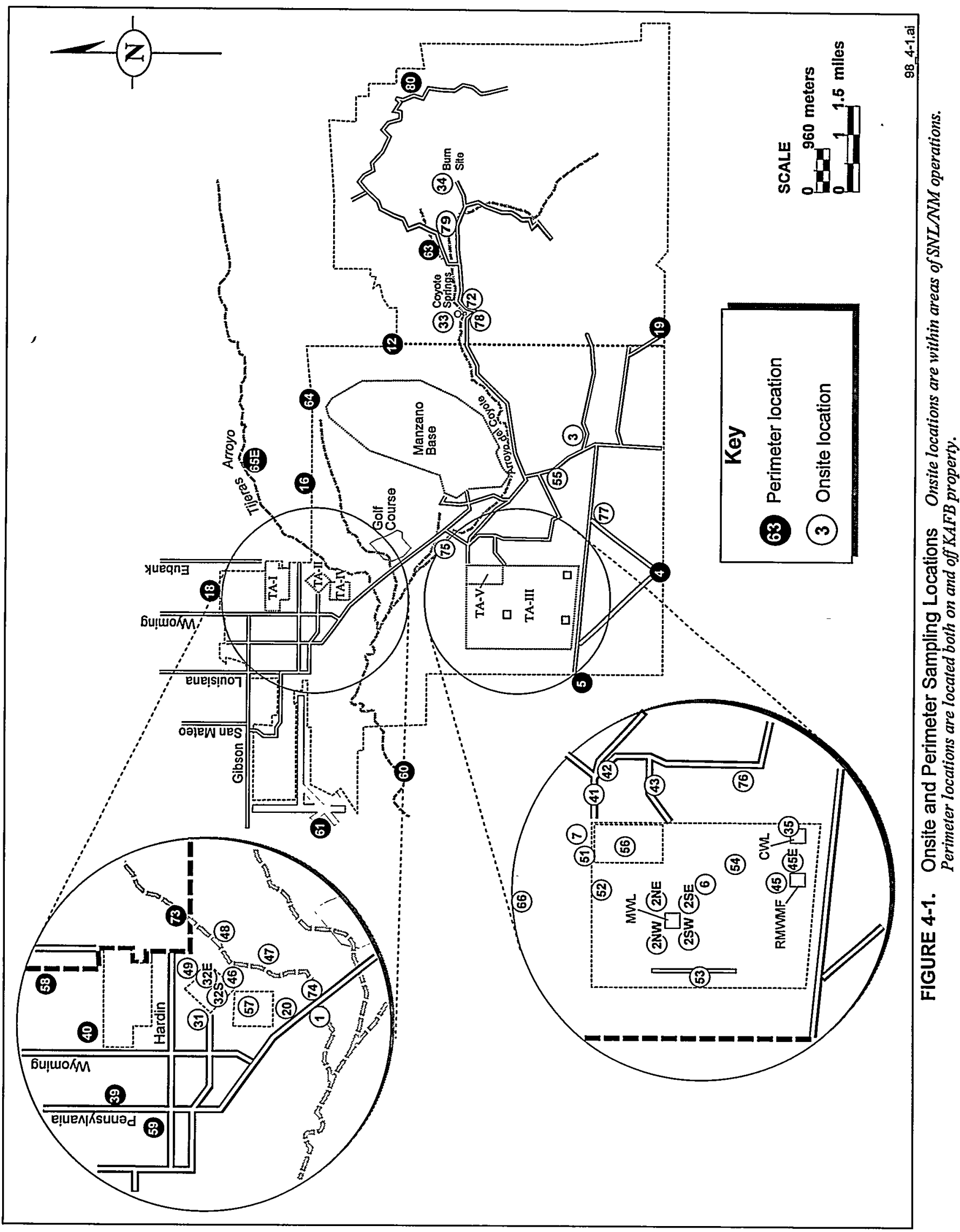


TABLE 4-1. Onsite Terrestrial Surveillance Locations and Sample Types

There are 39 onsite sampling locations.

\begin{tabular}{|c|c|c|c|c|c|c|}
\hline $\begin{array}{l}\text { Location } \\
\text { Number }\end{array}$ & Sampling Location & $\begin{array}{l}\text { Vege- } \\
\text { tation }\end{array}$ & Soil & $\begin{array}{c}\text { Surface } \\
\text { water }\end{array}$ & $\begin{array}{c}\text { Sedi- } \\
\text { ments }\end{array}$ & TLD \\
\hline 1 & Pennsylvania Ave. & & $\phi$ & & & 图 \\
\hline $2 N W$ & Mixed Waste Landfill (northwest) & $*$ & $\$$ & & & 目 \\
\hline $2 \mathrm{NE} *$ & Mixed Waste Landfill (northeast) & $*$ & $\phi$ & & & \\
\hline 2SE & Mixed Waste Landfill (southeast) & & $\phi$ & & & \\
\hline $2 \mathrm{SW}$ & Mixed Waste Landfill (southwest) & & 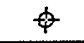 & & & \\
\hline 3 & Coyote Canyon Control & & $\$$ & & & 圆 \\
\hline 6 & TA-III (east of water tower) & $*$ & $\phi$ & & & 目 \\
\hline $7 *$ & Unnamed Arroyo (north of TA-V) & & $\$$ & & & 國 \\
\hline $20^{*}$ & TA-IV (southwest) & $\star$ & $\phi$ & & & 圆 \\
\hline 31 & TA-II Guard Gate & & & & & 固 \\
\hline $32 \mathrm{~S}$ & TA-II, Bldg. 935 (south bay door) & & $\phi$ & & & \\
\hline $32 \mathrm{E}$ & TA-II, Bldg. 935 (east personnel door) & & 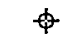 & & & \\
\hline 33 & Coyote Springs & $\bullet$ & $\phi$ & & & \\
\hline 34 & Lurance Canyon Burn Site & $\%$ & $\phi$ & & & \\
\hline 35 & Chemical Waste Landfill & 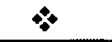 & $\$$ & & & \\
\hline 41 & TA-V (northeast fence) & & $\phi$ & & & 国 \\
\hline 42 & $T A-V$ (east fence) & $\$$ & 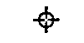 & & & 圈 \\
\hline 43 & $T A-V$ (southeast fence) & $\%$ & $\phi$ & & & 国 \\
\hline 45 & RMWMF, TA-III (northwest corner) & 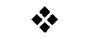 & $\phi$ & & & 圆 \\
\hline $45 \mathrm{E}$ & RMWMF, TA-III (east fence) & & & & & 国 \\
\hline 46 & TA-II (south corner) & $\%$ & $\$$ & & & 周 \\
\hline 47 & Tijeras Arroyo (east of TA-IV) & & & & & 图 \\
\hline 48 & Tijeras Arroyo (east of TA-II) & & & & & 目 \\
\hline 49 & Near the Explosive Component Facility (ECF) & $\%$ & $\phi$ & & & \\
\hline 51 & TA-V (north of culvert) & 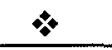 & $\phi$ & & & \\
\hline 52 & TA-III, northeast of Bldg. 6716 and 6717 & $\%$ & $\$$ & & & \\
\hline $53 *$ & TA-III south of long sled track & & $\phi$ & & & \\
\hline 54 & TA-III, Bldg. 6630 & & $\phi$ & & & \\
\hline 55 & Large Melt Facility (LMF), BIdg. 9939 & $*$ & $\phi$ & & & \\
\hline 56 & TA-V, Bldg. 6588 (west comer) & & $\phi$ & & & \\
\hline 57 & TA-IV, Bldg. 970 (northeast corner) & & $\phi$ & & & \\
\hline 66 & KAFB Facility & $\%$ & $\phi$ & & & \\
\hline 72 & Arroyo del Coyote (midstream) & & & & $\otimes$ & \\
\hline 74 & TA-IV, Tijeras Arroyo (midstream) & & & & $\otimes$ & \\
\hline 75 & Arroyo del Coyote (downgradient) & & & & $\otimes$ & \\
\hline 76 & Thunder Range (north) & & $\$$ & & & \\
\hline 77 & Thunder Range (south) & & $\Phi$ & & & \\
\hline 78 & South House Mesa & & $\phi$ & & & \\
\hline 79 & Arroyo del Coyote (upgradient) & & & & $\otimes$ & \\
\hline
\end{tabular}

NOTE: * Replicate sampling locations: In addition to single samples taken for each media, two replicate samples are collected for internal checks on consistency of laboratory results. RMWMF = Radioactive Mixed Waste Management Facility 
TABLE 4-2. Perimeter Terrestrial Surveillance Locations and Sample Types

There are 17 perimeter sampling locations.

\begin{tabular}{|c|c|c|c|c|c|c|}
\hline $\begin{array}{l}\text { Location } \\
\text { Number }\end{array}$ & Sampling Location & $\begin{array}{l}\text { Vege- } \\
\text { tation }\end{array}$ & Soil & $\begin{array}{c}\text { Surface } \\
\text { water }\end{array}$ & $\begin{array}{c}\text { Sedi- } \\
\text { ments }\end{array}$ & $\overline{T L D}$ \\
\hline 4 & Isleta Reservation Gate & 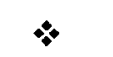 & $\psi$ & & & 因 \\
\hline 5 & McCormick Gate & $\nLeftarrow$ & $\phi$ & & & 可 \\
\hline 12 & Northeast Perimeter & $*$ & $\phi$ & & & \\
\hline 16 & Four Hills & & $\phi$ & & & 目 \\
\hline 18 & North Perimeter Road & & & & & 圈 \\
\hline 19 & USGS Seismic Center Gate & & $\phi$ & & & 圆 \\
\hline 39 & Northwest DOE Complex & & & & & 圈 \\
\hline 40 & TA-1, northeast (by Bldg. 852) & & & & & 圆 \\
\hline 58 & North Base Housing & $*$ & $\phi$ & & & \\
\hline 59 & Zia Park (southeast) & & $\phi$ & & & \\
\hline 60 & Tijeras Arroyo (downgradient) & $\%$ & $\phi$ & & $\otimes$ & \\
\hline 61 & Albuquerque International Sunport (west) & & $\phi$ & & & \\
\hline 63 & No Sweat Boulevard & & $\$$ & & & \\
\hline $64^{*}$ & North Manzano & $*$ & $\phi$ & & & \\
\hline $65 \mathrm{E}$ & Tijeras Arroyo, east (upgradient) & & $\phi$ & & $\otimes$ & \\
\hline $73^{*}$ & Tijeras Arroyo (upgradient) & & & & $\otimes$ & \\
\hline 80 & Madera Canyon & & $\phi$ & & & \\
\hline
\end{tabular}

NOTE: * Replicate sampling locations: In addition to single samples taken for each media, two replicate samples are collected for internal checks on consistency of laboratory results. 
Similarly, figure 4-2 shows offsite locations; table 4-3 lists the corresponding location information.

\section{$4.3 \begin{aligned} & \text { TERRESTRIAL MEDIA } \\ & \text { COLLECTED }\end{aligned}$}

Table 4-4 shows the type of analysis conducted on each media type collected. The sample size, collecting method, and sampling criteria for each environmental media sampled are described below.

Soil - Samples from 49 locations are used to ascertain the presence of air-deposited or surface runoff contaminants. A small trowel is used to scoop soil from the top few inches of the ground surface. Samples are desiccated before analysis.
Sediment - Samples were collected from 10 locations using the trowel scoop method. Desiccated samples are used to characterize water-transported or water-deposited contaminants. Samples were collected from dry arroyos at onsite and perimeter locations and from near the waters edge at the Rio Grande for offsite samples.

Vegetation - Samples are used to determine contaminants present in forage. Mostly grass was collected from 29 locations by cutting off the top portion of the plant. Grass is preferred due to its abundance and ubiquitous presence, although other vegetation is used if grass is not available.

Surface water - Samples from the Rio Grande were used to characterize the presence of waterborne contamination at upgradient and downgradient locations relative to SNL/NM. Las Huertas creek, due to a lack of water, was not sampled in 1997. Surface water at Coyote

TABLE 4-3. Offsite (Community) Terrestrial Surveillance Locations and Sample Types There are 16 offsite sampling locations within a 25-mile radius of SNL/NM operations.

\begin{tabular}{|c|c|c|c|c|c|c|}
\hline $\begin{array}{l}\text { Location } \\
\text { Number }\end{array}$ & Sampling Location & $\begin{array}{l}\text { Vege- } \\
\text { tation }\end{array}$ & Soil & $\begin{array}{c}\text { Surface } \\
\text { water }\end{array}$ & $\begin{array}{l}\text { Sedi- } \\
\text { ments }\end{array}$ & TLD \\
\hline 8 & Rio Grande, Corrales Bridge (upgradient) & $*$ & $\phi$ & $\downarrow$ & $\otimes$ & \\
\hline 9 & Sedillo Hill, I-40 (east of Albuquerque) & 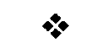 & $\phi$ & & & \\
\hline 10 & Oak Flats & $*$ & $\phi$ & & & 团 \\
\hline $11 *$ & Rio Grande, Isleta Pueblo (downgradient) & 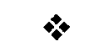 & $\phi$ & 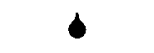 & $\otimes$ & 圆 \\
\hline 21 & Bernalillo Fire Station 10, Tijeras & & & & & 目 \\
\hline 22 & Los Lunas Fire Station & & & & & 圈 \\
\hline 23 & Rio Rancho Fire Station, 19th Ave. & & & & & 圆 \\
\hline 24 & Corrales Fire Station & & & & & 团 \\
\hline 25 & Placitas Fire Station & $*$ & $\phi$ & & & 国 \\
\hline 26 & Albuquerque Fire Station 9, Menaul NE & & & & & 圆 \\
\hline 27 & Albuquerque Fire Station 11, Southern SE & & & & & 娄 \\
\hline 28 & Albuquerque Fire Station 2, High SE & & & & & 团 \\
\hline 29 & Albuquerque Fire Station 7,47 th NW & & & & & 团 \\
\hline 30 & Albuquerque Fire Station 6, Griegos NW & & & & & 圆 \\
\hline 62 & East resident & $\star$ & $\phi$ & & & \\
\hline 68 & Las Huertas Creek** & & & & & \\
\hline
\end{tabular}

NOTE: * Replicate sampling locations: In addition to single samples taken for each media, two replicated samples are collected for internal checks on consistency of laboratory results.

**Not sampled in 1997 due to the creek being dry. 


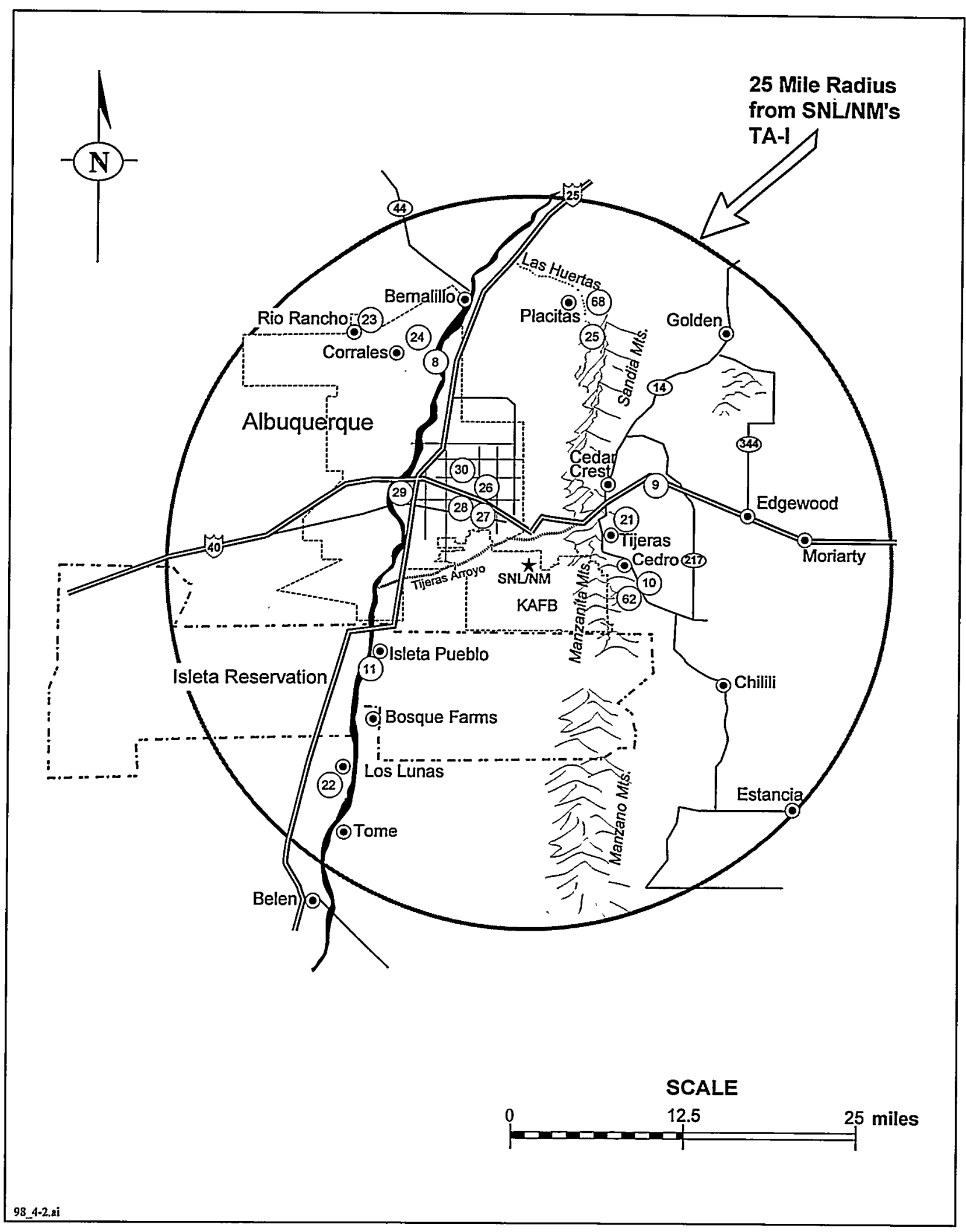

FIGURE 4-2. Offsite Sampling Locations 
TABLE 4-4. Analysis Performed on Environmental Media Sample Types

\begin{tabular}{|c|c|c|c|c|c|c|c|}
\hline \multirow{2}{*}{ Media } & \multicolumn{5}{|c|}{$\begin{array}{c}\text { Radiological } \\
\text { Analysis }\end{array}$} & \multicolumn{2}{|c|}{$\begin{array}{l}\text { Nonradiological } \\
\text { Analysis }\end{array}$} \\
\hline & $\begin{array}{l}\text { Gross } \\
\text { Alpha }\end{array}$ & $\begin{array}{c}\text { Gross } \\
\text { Beta }\end{array}$ & $\begin{array}{c}\text { Gamma } \\
\text { Spec }\end{array}$ & Tritium & $\mathrm{U}_{\text {tot }}$ & $\begin{array}{l}\text { ICP-20 } \\
\text { Metals }\end{array}$ & $\begin{array}{l}\text { Percent } \\
\text { H2O }\end{array}$ \\
\hline$\overline{\text { Soil }}$ & & & $\checkmark$ & $\bar{\checkmark}$ & $\checkmark$ & $\checkmark$ & $\checkmark$ \\
\hline Sediment & & & $\checkmark$ & $\checkmark$ & $\checkmark$ & $\checkmark$ & $\checkmark$ \\
\hline Vegetation & & & $\checkmark$ & $\bar{\checkmark}$ & $\checkmark$ & $\checkmark$ & $\bar{\checkmark}$ \\
\hline \multicolumn{8}{|l|}{ Surface Water } \\
\hline - Filtered & $\checkmark$ & $\checkmark$ & $\checkmark$ & $\checkmark$ & $\checkmark$ & $\bar{\checkmark}$ & \\
\hline - Unfiltered & $\checkmark$ & $\checkmark$ & $\checkmark$ & $\checkmark$ & $\checkmark$ & $\checkmark$ & \\
\hline $\begin{array}{l}\text { - Filters } \\
\text { (Suspended Solids) }\end{array}$ & $\checkmark$ & $\checkmark$ & $\checkmark$ & & $\checkmark$ & $\checkmark$ & \\
\hline
\end{tabular}

NOTE: $I C P=$ inductively coupled plasma.

$$
\text { Utot }=\text { Uranium, total }
$$

Springs was also not sampled and will no longer be sampled through the Terrestrial Surveillance Program. Onsite spring water is sampled by the Groundwater Protection Program. Water samples are separated into three divisions: unfiltered water (total water), filtered water, and suspended solids collected off filters (suspended solids $>0.45$ micron $[\mu \mathrm{m}]$ ).

\section{Thermoluminescent dosimeters (TLDs) -} Levels of gamma radiation in the ambient environment and measured with TLDs. Measurements were taken quarterly (TLDs were exchanged in January, April, July, and October) at 33 stations. Gamma radiation is emitted by various naturally occurring radionuclides, potentially contaminated areas, cosmic rays, and some test facilities at SNL/NM. TLDs are placed in aluminum poles at a height of $1-1.5 \mathrm{~m}$.

\subsection{PRIORITIZATION ANALYSIS}

Statistical new methodology developed in 1995 and published in 1997, referred to as Prioritization Statistical Analysis Methodology, is used to report current data (Shyr, Herrera, and
Haaker 1998). This method is based on categorizing sampling locations into four groups to simplify, and bring clarity to, the presentation of results.

Data from onsite and perimeter locations over the last 6 years (August 1991 to August 1997) were compared to data from offsite locations gathered during the same time period. This set of data provides a record from which to perform a trend analysis. Onsite and perimeter data were also compared to detection limits, U.S. surface soil averages (CRC 1992), proposed RCRA (Subpart S) action levels (where available), and Secondary Maximum Contaminant Levels for drinking water.

The prioritization method is based on two questions:

1. Are the results higher than offsite (baseline) measurements?

2. Is there an increasing trend over the last 6 years?

Table 4-5 lists the four priority level categories and specifies the actions that will be taken for each location depending on the designated category. Because Category 4 locations are of 
TABLE 4-5. Decision Matrix for Determining Priority Action Levels Based on Categories Assigned at Each Sampling Location

\begin{tabular}{|c|c|c|c|}
\hline $\begin{array}{c}\text { Are } \\
\text { contaminant } \\
\text { measurements } \\
\text { higher than } \\
\text { offsite? }\end{array}$ & $\begin{array}{c}\text { Is there an } \\
\text { increasing } \\
\text { trend over the } \\
\text { last 6 years? }\end{array}$ & Category & \multicolumn{1}{|c|}{ Priority for further investigation } \\
\hline Yes & Yes & 1 & $\begin{array}{l}\text { 1st Priority - Immediate attention needed. Specific } \\
\text { investigation planned and/or notifications made to } \\
\text { responsible parties. }\end{array}$ \\
\hline Yes & No & 2 & $\begin{array}{l}\text { 2nd Priority - Some concern. Investigation planned and/or } \\
\text { notifications made to responsible parties. }\end{array}$ \\
\hline No & Yes & 3 & $\begin{array}{l}\text { 3rd Priority - Only a minor concern since contaminants } \\
\text { present are not higher than offsite values. An investigation } \\
\text { may or may not be needed. }\end{array}$ \\
\hline No & No & 4 & $\begin{array}{l}\text { 4th Priority - No concern. No further investigation } \\
\text { required. }\end{array}$ \\
\hline
\end{tabular}

NOTE: Based on Prioritization Statistical Analysis Methodology (Shyr, Herrera, and Haaker 1998).

no concern, only Category 1,2 , and 3 locations will be discussed. However, since the inception of the method, no Category 1 locations (worst case) have been identified at the SNL/NM site.

\section{TERREstrial SURVEILlance RADIOLOGICAL RESULTS}

\subsubsection{Radiological Parameters}

The following sections present summary radiological data results from soil, sediment, vegetation, and surface water samples. A full report detailing terrestrial surveillance results can be found in the 1997 Environmental Surveillance Data Analysis Report (SNL 1998m).

Radiological analyses include the following analytical procedures performed on all sample media except where noted:

- Gross alpha - Detects the presence of alpha-emitting isotopes. A high result may trigger an isotopic analysis. Currently, this test is only run on water samples.
- Gross beta - Detects the presence of betaemitting isotopes. Again, a high result may trigger an isotopic analysis. Currently, this test is only run on water samples.

- Gamma spectroscopy - Identifies and quantifies the presence of gamma-emitting isotopes (such as cesium-137, a ubiquitous element present in the environment from nuclear atmospheric testing).

- Tritium - A common DOE-related contaminant that is also naturally occurring in the environment.

- Uranium, total $\left(U_{\text {tot }}\right)$ - A general trend indicator for detecting all isotopes of uranium. Elevated levels may trigger an isotope-specific analysis.

\subsubsection{Onsite and Perimeter Radiological Results}

The following paragraphs summarize the radiological results for onsite and perimeter locations with respect to each sample media and 
the radiological parameter tested. Locations that have been designated as Category 2 or 3 are also summarized in the shaded boxes. These results are presented graphically in figure 4-3. Environmental sampling by terrestrial surveillance staff is shown in figure 4-4.

\section{Vegetation Results for Tritium}

Location 2NE, near the Mixed Waste Landfill (MWL), continues to show Category 2 results for tritium. This is a known location of tritium contamination. This was the only site in 1997 that showed elevated radiological results for vegetation.

\begin{tabular}{|c|l|}
\hline \multicolumn{2}{|c|}{ Tritium - Vegetation } \\
\hline Category & \multicolumn{2}{|c|}{ Location } \\
\hline 2 & 2NE \\
\hline 3 & None \\
\hline
\end{tabular}

\section{Soil Results for Tritium}

There were no changes from the 1996 status for Category 2 sites. Locations 32E and 32S (east of TA-11) and location 2NE (near the MWL, are areas of known tritium soil contamination. All three remained elevated but showed no increasing trend. The average result for 1997 , combining these three sites, was 66.67 picocuries per milliliter $(\mathrm{pCi} / \mathrm{ml})$ (three times higher than last year, but less than previous years).

One new onsite location (52) and two perimeter locations (5 and 64) were noted with increasing trends (Category 3). Even though these locations are considered to have increasing trends, the concentrations observed are not operationally significant and do not pose a health hazard to individuals. Location 52 was observed to have concentrations between 0.10 and $0.29 \mathrm{pCi} / \mathrm{ml}$. Perimeter locations 5 and 64 were noted to have tritium concentrations between 0.12 and $1.60 \mathrm{pCi} / \mathrm{ml}$.

\begin{tabular}{|c|l|}
\hline \multicolumn{2}{|c|}{ Tritium - Soil } \\
\hline Category & \multicolumn{1}{|c|}{ Location } \\
\hline 2 & $32 \mathrm{E}, 32 \mathrm{~S}, 2 \mathrm{NE}$ \\
\hline 3 & $5,52,64$ \\
\hline
\end{tabular}

Soil Results for Uranium, total ( $\left.U_{\text {tot }}\right)$

There were no Category 2 (higher than community) locations observed for uranium total ( $U_{\text {tot }}$. However, an apparent widespread increasing trend in $U_{\text {tot }}$ was observed for both onsite and offsite locations (Category 3). Eighteen locations showed an increasing trend, compared to eleven last year. Because SNL/NM's radiological emissions have remained relatively unchanged, there was no obvious explanation for a significant increase. The statistical analysis surveillance team decided to pursue further investigations on the data to determine the cause of the apparent increases. It cannot be immediately assumed that the observed trend reflects real-world conditions since other factors, such as laboratory analytical fluctuations, can also be the cause.

The statistical team first plotted the data results from 1991 through 1997. An anomalous low appeared for August 1991 and May 1992 results. The team then requested the analytical laboratory (the one used for all sampling periods) to review its records to see if there were any internal reasons for the low values. After reviewing equipment records, the analytical laboratory found that either the analytical method or the equipment had been changed during the summer of 1992. Although, there is no way of knowing for certain, the change in equipment or method is a potential cause of the anomalous lows shown in the data analysis.

SNL/NM's statistical procedure evaluates each sample period and then compares it to each sample period thereafter to determine if values are increasing. The two lower periods, therefore, significantly skew the analytical results and showed the appearance of an increasing trend. On the assumption that these two results may not be valid, it was decided to re-run the statistical analysis without the August 1991 and May 1992 sampling data. The new analysis, excluding the two sampling periods, showed seven locations with increasing trends: $1,4,7,12,35,51$, and 54 . Of these locations, 


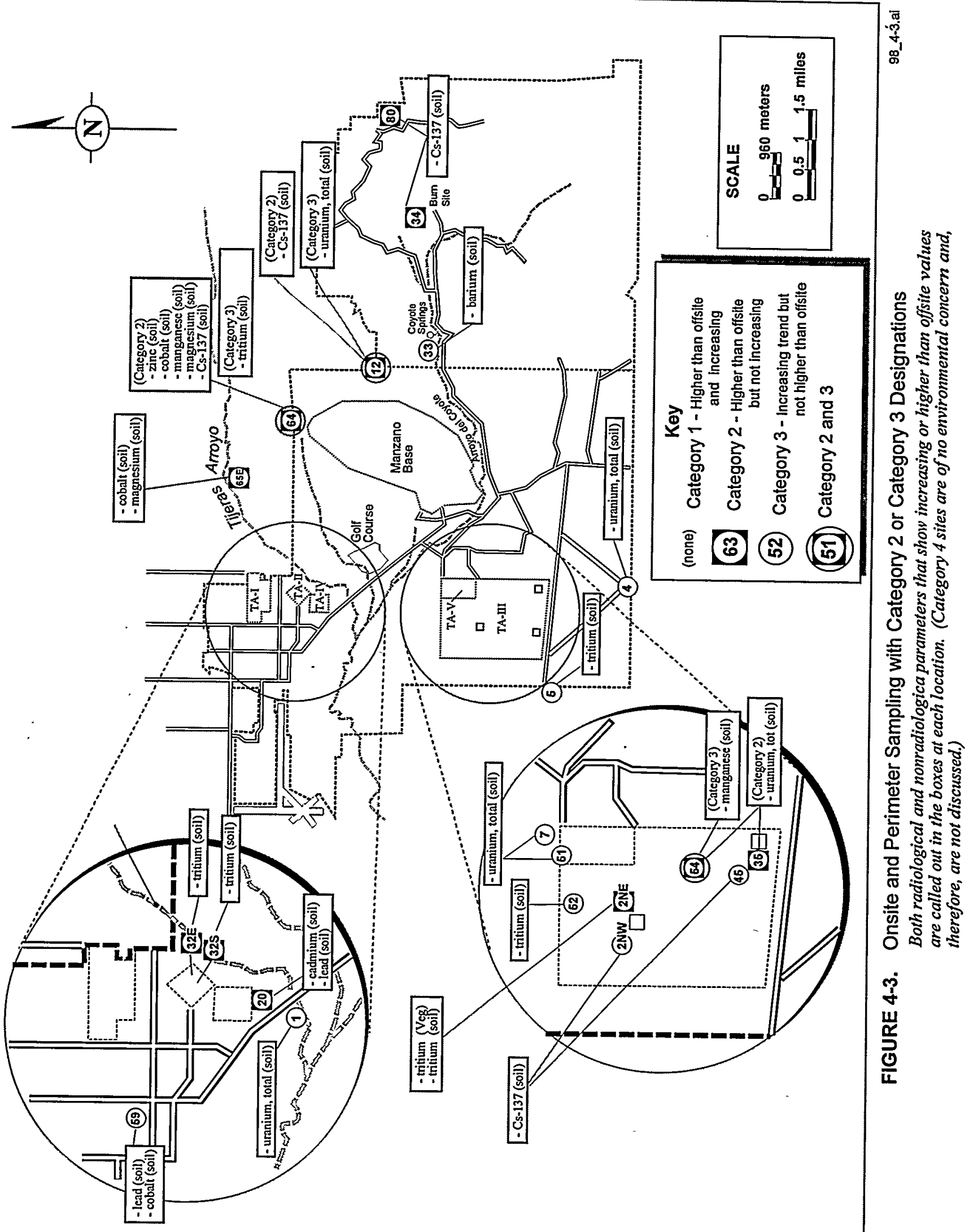


increasing trends for $U_{\text {tot }}$ were observed at 1,4 , 12 , and 51 during the 1996 data analysis. $\mathrm{U}_{\text {tot }}$ concentrations ranged form 0.5 micrograms per gram $(\mu \mathrm{g} / \mathrm{g})$ to $3.0 \mu \mathrm{g} / \mathrm{g}$ in all onsite and perimeter locations. These same concentrations were observed in the offsite locations (i.e., background).

All data analysis for the Terrestrial Surveillance Program is recorded in a notebook and can be viewed upon request. All locations that showed an increasing trend in the subsequent data analysis will be monitored to determine if the trend continues. Both sets of analyses, with and without August 1991 and May 1992 sample periods, will be performed next year to determine if similar statistical results occur again.

\begin{tabular}{|l|l|}
\hline Uranium, total $\left(\mathrm{U}_{\text {tot }}\right)$ - Soil \\
\hline Category & Location \\
\hline 2 & None \\
\hline 3 & $1,4,7,12,35,51,54$ \\
\hline
\end{tabular}

NOTE: Results are from analysis excluding anomalous lows from 1991 and 1992.

Soil Results for Cs-137

Elevated results with no increasing trend (Category 2) were noted at locations $12,34,64$, and 80 ; all were on or near the withdrawal area in the northeast section of KAFB. Location 80 was added during the 1995 sampling period and is considered to be a fairly new sample location. No trend could be computed since there are only three results observed. Location 80 was not sampled during 1996; the road leading to the sample site was washed out and the sample location was unreachable. Category 3 sites were noted at locations $2 \mathrm{NW}$ and 45 near the MWL and the Radioactive and Mixed Waste Management Facility (RMWMF), respectively. Results from onsite sampling ranged from 0.11 $\mathrm{pCi} / \mathrm{g}$ to $0.98 \mathrm{pCi} / \mathrm{g}$. These values are within the range of background $\mathrm{Cs}-137$ concentrations from soils in the Albuquerque vicinity (Hostak 1995). Offsite results ranged from 0.13 to 0.58 $\mathrm{pCi} / \mathrm{g}$.

\begin{tabular}{|c|l|}
\hline Cesium-137 - Soil \\
\hline Category & \multicolumn{1}{|c|}{ Location } \\
\hline 3 & $2 \mathrm{NW}, 45$ \\
\hline 2 & $12,34,64,80$ \\
\hline
\end{tabular}

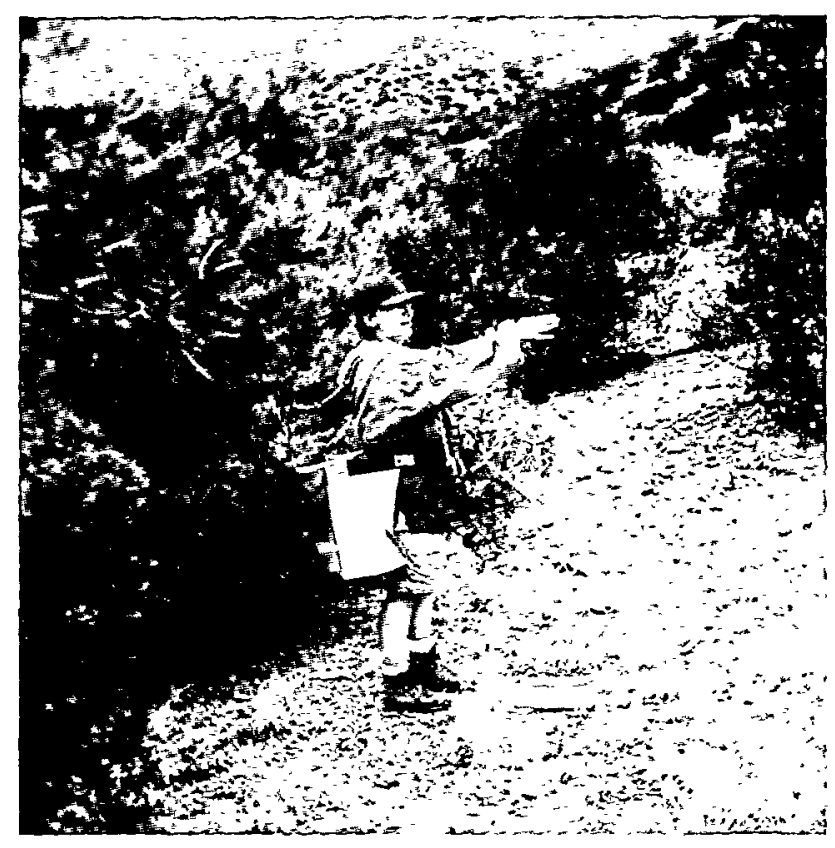

FIGURE 4-4. Sandia's Stephanie Pope Setting Up Line Transects for Small Mammal Capture and Release Study

\section{Radiological Results for Surface Water} There are no surface water sample locations onsite. Coyote Springs was sampled through 1996 as part of the Terrestrial Surveillance Program, but is now sampled only by the Groundwater Protection Program. Groundwater Protection has sampled Coyote Springs in the past and it was felt that this program should have sole responsibility for onsite water sampling.

Thermoluminescent Dosimeter (TLD) Results In 1996, the RMWMF began operation. As a result of the handling of low level radioactive waste (LLW) at this facility, locations 45 and $45 \mathrm{E}$ are no longer considered representative of ambient levels of gamma radiation onsite at SNL/NM and are now classified as operational. 
All results are reported to RMWMF facility personnel. Table 4-6 shows 1997 TLD results for comparison purposes. The entire sampling period for 1997 was 374 days (January 7, 1997 through January 12, 1998).

In 1998, to retain consistency with other terrestrial surveillance activities at SNL/NM, TLD results from 1991 through 1997 were compared for statistical analysis purposes, although TLD results from 1983 through 1996 are on file and readily accessible.

Only onsite, perimeter, and offsite TLD results will be compared. (Locations 45 and 45E are excluded from the statistical analysis for reasons mentioned above.) In 1997, there were no statistical differences between onsite, perimeter, and offsite (community) TLD results. Figure 4-5 shows TLD results from 1991 through 1997 by location class.

\subsection{TERRESTRIAL SURVEILLANCE NONRADIOLOGICAL RESULTS}

\subsubsection{Nonradiological Parameters}

Beginning in 1993, the scope of the Terrestrial Surveillance Program was broadened to include sample analysis of certain metals that are key indicators of contaminants in soil. The list of 21 metals has been modified over time to best represent a broad range of toxic pollutant indicators that are based on RCRA and CERCLA target list metals. The list has also been modified over time by removing some metals that naturally occur in local soils and present no significant health risks. For example, silicon, calcium, strontium, and titanium were removed from the analyte list in 1996 and replaced by thallium, selenium, arsenic, and antimony. Metals (with the exception of mercury) are analyzed by EPA's Inductively Coupled Plasma-Atomic Emission Spectrum (ICP-AES) method. The 21 nonradiological parameters are as follows:

$\begin{array}{ll}\text { Aluminum (Al) } & \text { Mercury (Hg) } \\ \text { Arsenic (As) } & \text { Manganese (Mn) } \\ \text { Antimony (Sb) } & \text { Magnesium (Mg) } \\ \text { Barium (Ba) } & \text { Nickle (Ni) } \\ \text { Beryllium (Be) } & \text { Potassium (K) } \\ \text { Chromium (Cr) } & \text { Silver (Ag) } \\ \text { Cadmium (Cd) } & \text { Selenium (Se) } \\ \text { Cobalt (Co) } & \text { Thallium (Tl) } \\ \text { Copper (Cu) } & \text { Vanadium (V) } \\ \text { Iron (Fe) } & \text { Zinc (Zn) } \\ \text { Lead (Pb) } & \end{array}$

As was done for radiological results, locations were categorized from 1 to 4 based on the contamination present and the results from the trend analysis. (Again, there were no sites designated as Category 1). Category 4 locations are of no environmental concern and are not

TABLE 4-6. Thermoluminescent Dosimeter Results for 1997 (millirem per year)

\begin{tabular}{|l|c|c|c|c|c|}
\hline \multicolumn{1}{|c|}{ Location Class } & Sample Size & Mean & Std Dev & Minimum & Maximum \\
\hline SNL/NM (Operational) & 2 & 177.60 & 77.36 & 120.9 & 232.30 \\
\hline SNL/NM (Onsite) & 13 & 99.68 & 7.78 & 95.1 & 110.40 \\
\hline Perimeter & 7 & 91.11 & 11.33 & 92.7 & 102.30 \\
\hline Offsite & 12 & 94.76 & 9.83 & 80.7 & 112.80 \\
\hline
\end{tabular}




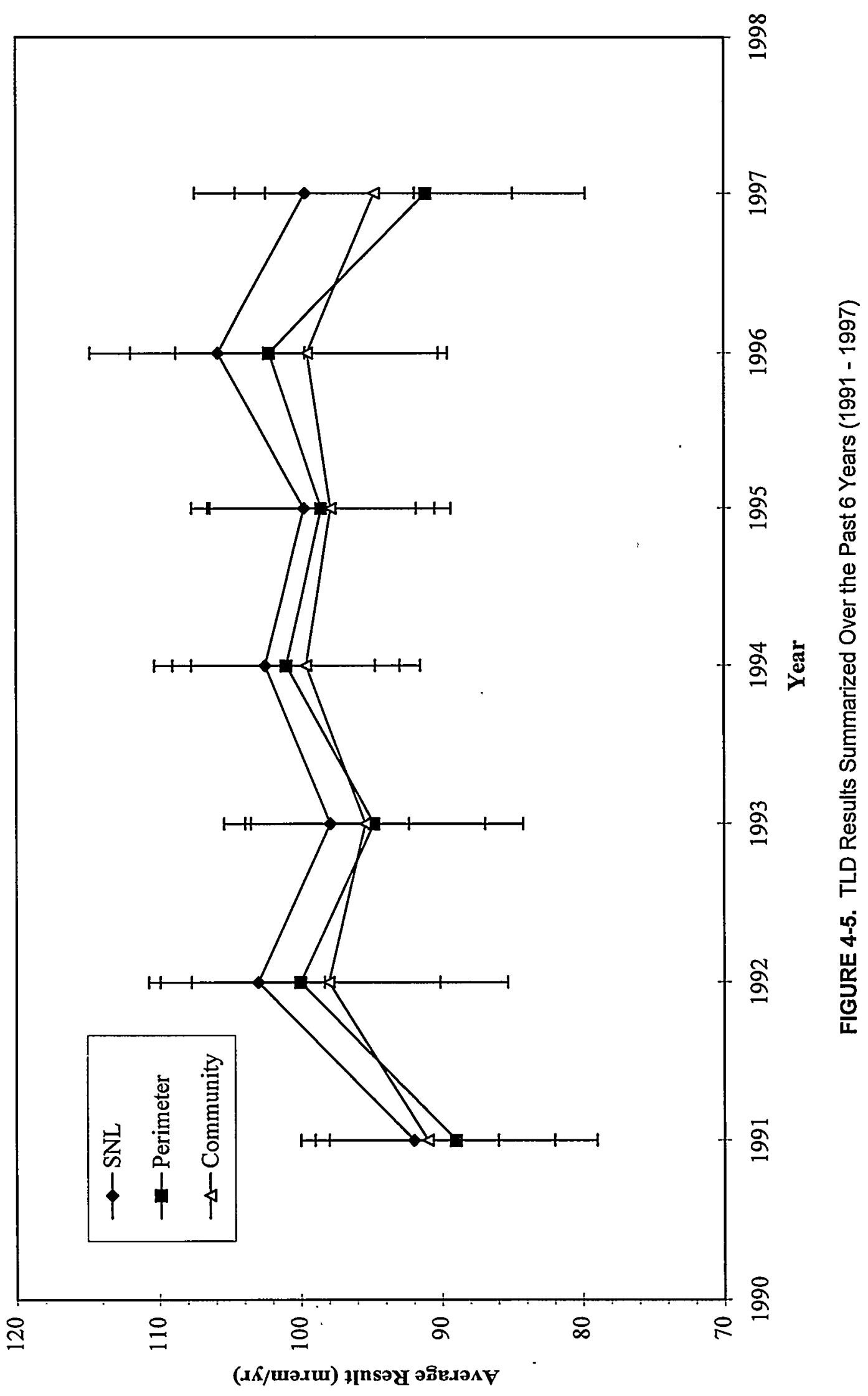


discussed. Figure 4-3 shows locations where nonradionuclide contaminants have been assigned a Category 2 or Category 3 designation. A full report detailing terrestrial surveillance data results can be found in the 1997 Environmental Surveillance Data Analysis Report (SNL 1998m).

\subsubsection{Onsite and Perimeter Nonradiological Results}

\section{Soil Results for Metal Parameters}

Category 2 sites included location 20 (near the skeet range) for cadmium and lead; $65 \mathrm{E}$ and 64 for cobalt and manganese; and 64 for cobalt, magnesium, manganese, and zinc. Category 3 sites included location 33 for barium, 59 for cobalt and lead, and 54 for manganese. These sites are discussed individually below.

Positive indications are that 27 of the 56 total onsite and perimeter sampling locations were designated as Category 4 (no concern). Many of these sites showed values significantly below community levels and/or demonstrated decreasing trends.

- Location 20 - Located at the KAFB skeet range. Samples are elevated for lead in the soil with an average of 7,400 parts per million (ppm) (1993-1997). A toxicity characteristic leaching procedure (TCLP) for lead was performed on soil samples to determine if lead shot from the skeet range was leaching into the soil; results indicate that it is not. The test results were forwarded to the USAF and the ER Project to determine if further action is needed for this location. Average offsite lead values in soils were $22.05 \mathrm{ppm}$ (1993-1997).

- Location 64 - Located on the KAFB perimeter north of Manzano base. Samples were elevated for cobalt, manganese, and zinc as was the case for previous years. Additionally, magnesium was observed to have elevated concentrations this year for the first time. The average concentration of magnesium at location 64 was $6,637 \mathrm{ppm}$. The maximum concentration of $9,400 \mathrm{ppm}$ was recorded in August 1993; the minimum concentration of $5,600 \mathrm{ppm}$ was recorded in July 1997. The proposed RCRA Subpart S action level for magnesium is $46,000 \mathrm{ppm}$, which is above our observed concentrations. It should be noted that EPA does not consider magnesium a hazardous metal.

Maximum cobalt concentration was recorded in August 1993 at $14 \mathrm{ppm}$. This is well below the proposed RCRA action level $(4,800 \mathrm{ppm})$ and also within the range of U.S. surface soil background cobalt concentrations ( 3 to $50 \mathrm{ppm}$ ) (CRC 1992).

Maximum concentration for manganese was reported at $760 \mathrm{ppm}$ in August 1993. Although high, and above the proposed RCRA action level of $400 \mathrm{ppm}$, this was still within the average U.S. surface soil background levels of $20-3,000 \mathrm{ppm}$. All other manganese results for 19 locations were between 490 and $590 \mathrm{ppm}$. Monitoring will continue at this site. If increasing levels continue to be noted, further analysis of this site will be initiated.

The maximum value for zinc was reported in August 1993 at $110 \mathrm{ppm}$ (significantly below the proposed RCRA action level of $23,000 \mathrm{ppm})$. Since then, values have ranged between 64 and $78 \mathrm{ppm}$. In 1997, the average perimeter and offsite values were $38 \mathrm{ppm}$ and $41.17 \mathrm{ppm}$, respectively; the average onsite value was $40.6 \mathrm{ppm}$. The highest reported value was still within the range of average U.S. surface soil concentrations of 13-300 ppm (CRC 1992).

- Location 65E - A fairly new perimeter location that was added in 1995. This location is located near the Tijeras Arroyo just upgradient of the point where the arroyo crosses over onto KAFB property. The 
location is designated as Category 2 with elevated manganese and cobalt concentrations. The maximum cobalt concentration of $12 \mathrm{ppm}$ reported in 1996 is, however, significantly below the proposed RCRA action limit of $4,800 \mathrm{ppm}$, and well within the average U.S. surface soil background levels of 3-50 ppm (CRC 1992). Manganese concentrations range from 220 to $750 \mathrm{ppm}$; however, most are above the proposed RCRA action limit of $400 \mathrm{ppm}$. Due to the limited sample size (four since 1995), monitoring will continue and any developing trends noted.

- Location 33 - Within the withdrawal area at Coyote Springs. This location is controlled for access. The site has also been posted, "Not a Source for Drinking Water," although it is still made available for local wildlife. For.the second time, it was noted that barium in the soil shows an increasing trend (Category 3 ) with values ranging from 86 to $150 \mathrm{ppm}$. These concentrations are well within the range reported for SNL/NM soil concentrations (IT 1996). The range for U.S. surface soils is $20-1,500 \mathrm{ppm}$ (CRC 1992). The proposed RCRA Subpart $S$ residential action limit for barium is 5,600 ppm. Although no action is planned at this time because of the small values, monitoring will continue.

- Location 59 - Located at the corner of Hardin Road and Pennsylvania Boulevard near the on-base Zia Park Housing area. This is the second straight year that lead has shown an increasing trend (Category 3 ) at this location. Since 1993, lead concentrations range from 8 to $21 \mathrm{ppm}$. The concentrations observed at location 59 are within the range of U.S. soil surface concentrations of 10-70 ppm (CRC 1992); there is no proposed RCRA Subpart $\mathrm{S}$ action level for lead. Monitoring will continue at this location and an evaluation as to possible causes for the increasing trend will be made.
Cobalt showed an increasing trend (Category 3) for the first time this year. Cobalt concentrations range from 3.4 to 4.4 ppm since metals analysis was begun in 1993. These concentrations are well below the proposed RCRA Subpart S action level of $4,800 \mathrm{ppm}$ and are also within the range of U.S. surface soil background cobalt concentrations of 3-50 ppm (CRC 1992).

- Location 54 - is located within TA-III, near Bldg. 6630. For the second time, this location showed an increasing trend for manganese. Manganese concentrations are in the range of 140 to $170 \mathrm{ppm}$ and are within the range of U.S. surface soil background levels of 20-3,000 ppm (CRC 1992), falling below the proposed RCRA action level of $400 \mathrm{ppm}$. The location will continue to be monitored closely to determine if manganese concentrations continue to show an increasing trend.

\begin{tabular}{|c|l|}
\hline Soil - Barium \\
\hline Category & \multicolumn{1}{|c|}{ Location } \\
\hline 2 & None \\
\hline 3 & 33 \\
\hline
\end{tabular}

\begin{tabular}{|c|l|}
\hline \multicolumn{2}{|l|}{ Soil - Cadmium } \\
\hline Category & \multicolumn{1}{c|}{ Location } \\
\hline 2 & 20 \\
\hline 3 & None \\
\hline
\end{tabular}

\begin{tabular}{|c|l|}
\hline Soil - Cobalt \\
\hline Category & \multicolumn{1}{|c|}{ Location } \\
\hline 2 & $64,65 \mathrm{E}$ \\
\hline 3 & 59 \\
\hline
\end{tabular}

\begin{tabular}{|c|c|}
\hline Soil - Lead & \\
\hline Category & \multicolumn{1}{|c|}{ Location } \\
\hline 2 & 20 \\
\hline 3 & 59 \\
\hline
\end{tabular}

\begin{tabular}{|c|l|}
\hline \multicolumn{2}{|c|}{ Soil - Magnesium } \\
\hline Category & \multicolumn{1}{|c|}{ Location } \\
\hline 2 & $64,65 \mathrm{E}$ \\
\hline 3 & None \\
\hline
\end{tabular}




\begin{tabular}{|c|c|}
\hline \multicolumn{2}{|l|}{ Soil - Manganese } \\
\hline Category & Location \\
\hline 2 & 64 \\
\hline 3 & 54 \\
\hline
\end{tabular}

Soil - Zinc

\begin{tabular}{|c|l|}
\hline Category & \multicolumn{1}{|c|}{ Location } \\
\hline 2 & 64 \\
\hline 3 & None \\
\hline
\end{tabular}

Sediment Results For All Metal Parameters Sediments are collected from seven onsite and perimeter sampling locations at several points along two arroyos: Tijeras Arroyo and Arroyo del Coyote. There were no Category 2 or Category 3 designations. Location 73 (a perimeter location) showed increasing lead values in 1995 and 1996, but no longer shows an increasing trend in 1997.

\section{Surface Water Results For All Metal Parameters}

Surface water grab samples were done only at the Rio Grande for 1997. As mentioned earlier, the Groundwater Protection Program has responsibility for sampling Coyote Springs. Also, Las Huertas creek, location 68, was not sampled since the creek bed was dry. The Rio Grande, being an offsite location, is not classified as either a Category 2 or Category 3. It was determined that there is no statistical difference between the up-gradient and the down-gradient sampling locations.

\section{7 $\begin{aligned} & \text { NON-ROUTINE SURVEILlanCe } \\ & \text { ACTIVITIES }\end{aligned}$}

\section{Liquid Effluent Control System (LECS)}

Two non-routine soil samples were collected outside the LECS in TA-III. The samples were collected to provide a baseline of soil radiological conditions in anticipation of increased usage of the LECS (when the Medical Isotope Production Project [MIPP] becomes operational). Although no surface discharges from the LECS are anticipated, this sampling provides baseline conditions in the event of an unplanned release.

\section{City of Albuquerque Soil Amendment \\ Facility}

Non-routine soil samples were collected at the City of Albuquerque Soil Amendment Facility (SAF). Sludge from the sewer treatment plant is trucked to the facility and allowed to dry. Some is taken for sale as compost at local nurseries, and the rest is tilled into the ground at one of 16 fields at the SAF. The fields are rotated on a semi-annual basis, such that each field is used for approximately 6 months every 7 years.

SNL/NM is currently prohibited from discharging any measurable radioactivity above natural background into the sanitary sewer system. In anticipation of a change to the City of Albuquerque's Sewer Use and Wastewater Control Ordinance, which should allow discharges of low-level radioactivity by SNL/NM, samples were collected from each of the 16 fields at the SAF to establish a baseline level of radioactivity at the facility. A sample was also taken from sludges that are set aside for sale to the public. Since some institutions (primarily hospitals) are currently allowed to discharge radioactive materials to the sanitary sewer, this baseline sampling should aid in future evaluations of SNL/NM's contribution, if any, to the radiological conditions at the SAF.

SAF samples were analyzed for gamma spec, tritium, and $U_{\text {tot }}$. The handling, treatment, and tilling process makes it reasonable to assume that any radioactivity present in any given field is distributed fairly homogeneously. Nevertheless, to ensure that the samples were as representative as possible of the average conditions at each field, the samples were collected as composites from the (approximate) four quadrants of each field.

The sample results indicated no unexpected levels of radioactivity. Because the samples are a mixture of sludge and soil, there is no real "background" point of comparison for this type 
of sample. $U_{\text {tot }}$ was detected at levels 0.7 to 5.3 times that seen in SNL/NM's offsite surface soil samples. This is likely due to the concentration in sludge of naturally occurring uranium in groundwater. Cs-137 was detected in many of the samples, but the concentrations were at or below that seen in background surface soils due to fallout from nuclear testing. This is likely due to the dilution caused by mixing with sludge that has relatively low Cs-137 concentrations, as well as the tilling process itself (mixing with subsurface soils). Tritium was detected at levels from 6.4 to 74 times that seen in SNL/NM's offsite surface soil samples. The possible causes of this difference in tritium levels are being studied.

\section{MWL Radon Flux Monitoring .}

Radon flux monitoring was conducted at the Mixed Waste Landfill (MWL) (ER Site 76), to support a planned exemption request for such monitoring when 10 CFR 834, "Radiation Protection of the Public and the Environment," becomes final. This site was chosen since it is the only known area at SNL/NM where radium sources potentially exist in sufficient quantity to cause radon gas emissions requiring monitoring under the proposed law.

Samples were collected using standard passive collection devices (four-inch charcoal canisters), inverted such that the open side of the canister was exposed to the ground surface. The canisters were counted by gamma spectroscopy at the TMA Eberline ${ }^{\mathrm{TM}}$ facility in Albuquerque, and the results converted to radon flux. A total of 100 canisters were used: 50 on the classified portion of the landfill, 12 on the northern half of the unclassified portion of the landfill, and 9 on the southern half of the unclassified portion of the landfill. Also, 18 canisters were placed outside the landfill boundary to represent background flux conditions, and 9 canisters were placed face up on the classified portion of the landfill to measure ambient radon concentrations. Two canisters were submitted as blanks.
The results showed that there was no statistical difference between the radon flux inside and outside the landfill. An exemption request will be prepared, when 10 CFR 834 is issued, to relax any radon monitoring requirements at the MWL.

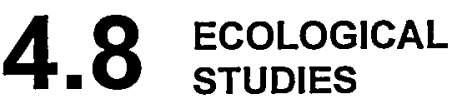

\section{TA-II Monitoring Study}

Ecological monitoring was conducted at SNL/NM over a period of 4 months from June through September 1997. The intent of the study was to collect baseline information and contamination data on small mammals, reptiles, amphibians, birds, and vegetation.

A comparison was made between animal and plant populations inhabiting or frequenting TAII and similar species found at a control site. TA-II is the site of several ER areas including the Classified Waste Landfill. The control site in 1997 was located at the southeastern end of KAFB near the perimeter fence between the Base and the Isleta Pueblo. Various data sets were compiled including visual population counts, catch-and-release trapping, and wildlife specimen collection for tissue analysis.

The two basic components of the study were baseline monitoring and contamination monitoring. Baseline monitoring is performed to record basic environmental conditions at both the control site and TA-II, such as population density estimates, and plant/animal species identification. In 1997, however, population data were not taken at the control site due to budget restraints.

The catch-and-release portion of the study recorded individual data on each captured animal, including species, sex, various body dimensions, and number of recaptures. The contaminant monitoring portion of the study 
required several mice to be collected for wholebody tissue analysis to determine what internal contaminant loads were present. Tissue samples were analyzed for radiological parameterstritium, strontium-90, $U_{\text {tot }}$, and by gamma spectroscopy. Nonradiological parameters included all metals as listed in section 4.6.1. Results were compared to determine statistical differences between species located in the vicinity of TA-II with species from the uncontaminated control site.

Small mammals found at TA-II included: the silky pocket mouse (Perognathus flavus), the deer mouse (Peromyscus maniculatus), and the house mouse (Mus Mustella). Ten bird species were recorded including the house finch (Carpodacus mexicanus) and the Western Meadowlark (Sturnella neglecta).

Contamination data were collected using mice for whole body tissue analysis at both the study site and the control site. Animals collected included the Western harvest mouse (Reithrodontomys megalotis), Merriam's kangaroo rat (Dipodomys merriami), Northern grasshopper mouse (Onchomys leucogaster), plains woodrat (Neotoma microtus), whitefooted mouse (Peromyscus leucopus), deer mouse, and silky pocket mouse. Tissue samples were analyzed for tritium, strontium-90, $U_{\text {tot }}$, gamma spectroscopy, and metals to determine differences in analyte concentration between the study site and control site. No statistical difference was noted between the two sites. All results are given in the ecological monitoring report (SNL 1998n).

Terrestrial Surveillance Document Summary All important program documents related to activities conducted by the Terrestrial Surveillance Program are listed in table 4-7.

TABLE 4-7. Important Documents for the Terrestrial Surveillance Program

\begin{tabular}{|l|l|}
\hline Program Document & Reference \\
\hline $\begin{array}{l}\text { SNL/NM Summary Pamphlet Calendar Year 1997, Summary of the } \\
\text { Annual Site Environmental Report (ASER) }\end{array}$ & SNL 1998o \\
\hline Environmental Monitoring Plan & SNL 1996g \\
\hline Environmental Monitoring and Surveillance Program (PG) & SNL 1997d \\
\hline Quality Assurance Project Plan (QAPjP) for Terrestrial Surveillance & SNL 1996h \\
\hline Environmental ALARA Program (PG) & SNL 1996i \\
\hline $\begin{array}{l}\text { The Role of Data Analysis in Sampling Design of Environmental } \\
\text { Monitoring }\end{array}$ & $\begin{array}{l}\text { Shyr, Herrera, and Haaker } \\
1998\end{array}$ \\
\hline $\begin{array}{l}\text { Ecological Monitoring for 1997: Small Mammals, Reptiles, } \\
\text { Amphibians, Birds, and Vegetation }\end{array}$ & SNL 1998n \\
\hline
\end{tabular}

NOTE: PG denotes a "Program Document," which is a special type of ES\&H document. 


\section{- Air Quality Compliance and Meteorological MONITORING}

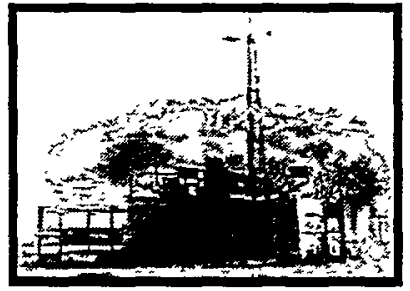

$\mathrm{S}$ NL/NM produces both radiological and nonradiological air pollutants from facility operations that include research and development activities, environmental remediation, waste handling, steam-generated heating, paint and machine shop production, emergency generator use, and vehicle emissions. Air quality compliance is met by adhering to specific permit conditions, keeping required records, and periodic direct emission sampling, as required. SNL/NM complies with local, state, and federal regulations in accordance with the objectives of the Clean Air Act (CAA) and the Clean Air Act Amendments (CAAA) of 1990.

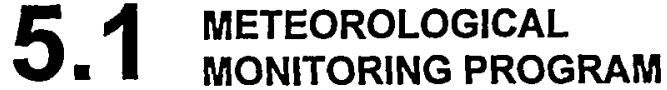

The Meteorological Monitoring Program at SNL/NM commenced operations in January 1994 with the initiation of the Clean Air Network (CAN) Program. This program, which is part of the Environmental and Emergency Management Department, conducts both meteorological and ambient air monitoring activities (Section 5.2).

The Meteorological Program is essential to compliance with the following regulations:
- 10 CFR 834 (proposed), Radiation Protection of the Public and the Environment.

- 40 CFR 51, Guidelines for Onsite Meteorological Measurements.

Additionally, the program structure is based on the guidelines given in DOE Orders-5400.1, General Environmental Protection Program (DOE 1990a), 5400.5, Radiation Protection of the Public and the Environment (DOE 1993a), and 151.1, Comprehensive Emergency Management (DOE 1996d).

Meteorological data generated is used in air dispersion modeling as well as in support of regulatory permitting. All data are consistent with program guidelines required for these regulatory modeling applications.

\section{Tower Instrumentation}

The meteorological monitoring network consists of eight fully instrumented meteorological towers: six 10-meter towers, one 50-meter tower, and one 60-meter tower. Tower locations are illustrated in figure 5-1. All meteorological towers are instrumented to measure temperature, wind velocity, and the standard deviation of horizontal wind speed (sigma theta) at 3- and 10-meter levels, and at the top of the two taller towers (with the exception of tower A15, which has no 3-meter level instrumentation). Additionally, relative humidity is measured at all 


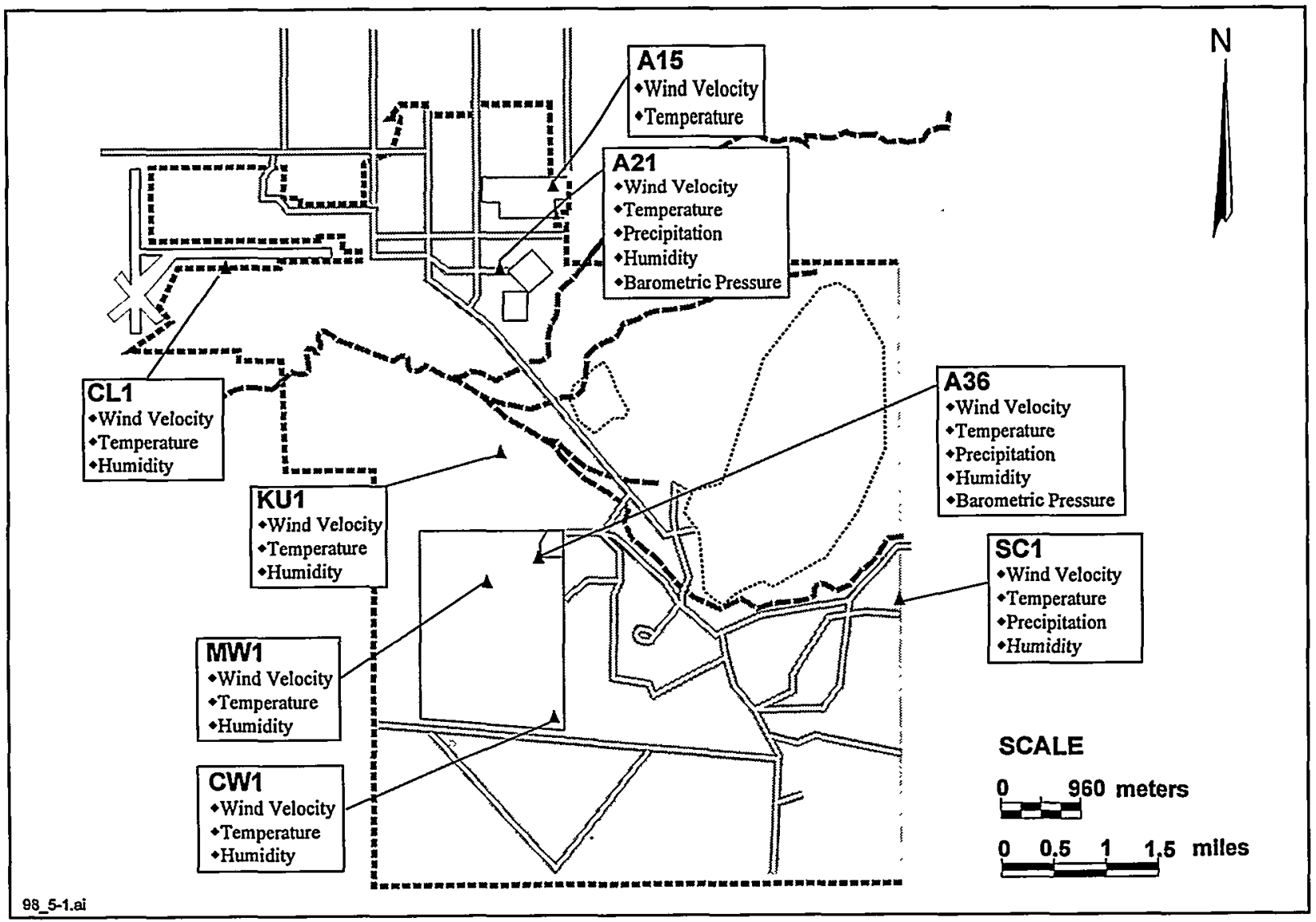

FIGURE 5-1. The Meteorological Tower Network at the SNL/NM Site

3-meter instrumented levels. Both rainfall and barometric pressure are measured at the 1-meter level at towers $\mathrm{A} 36$ and $\mathrm{A} 21$; tower $\mathrm{SC} 1$ measures rainfall only at the 1-meter level. All instrumentation is checked weekly and calibrated on a routine basis.

\section{Uses for Meteorological Data}

The primary objective of the Meteorological Monitoring Program is to provide representative local meteorological data for atmospheric dispersion and transport calculations. Other uses include: providing meteorological information to emergency response personnel in the event of a hazardous or other unplanned release, contributing to the regulatory permitting process and decision making, determining optimum air monitoring station locations, and providing meteorological data to SNL/NM's research and development projects.

\subsubsection{Meteorological Monitoring Results}

The A36 60-meter tower is used to describe general meteorology at SNL/NM because of its central geographic position and availability of data at all instrument levels. The A15 50-meter tower, while closer to the most populous part of SNL/NM in TA-I, shows micro-scale urbanization effects not seen within the rest of the network. The 1997 annual climatic summary, which was developed using information from the A36 tower, is shown in table 5-1. 


\section{Annual Climatic Summary of the A36 Tower}

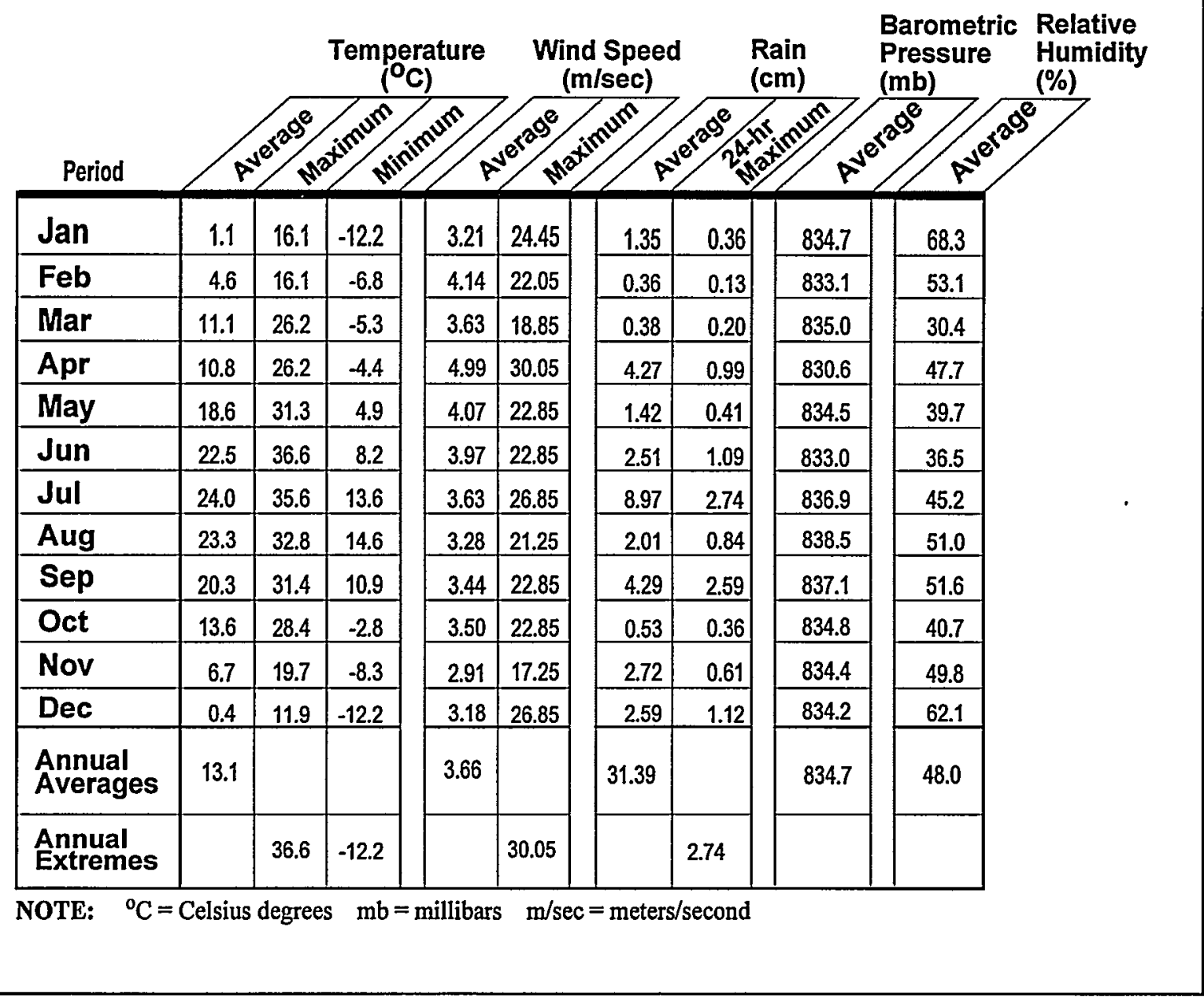

TABLE 5-1. The 1997 Annual Climatic Summary from Tower A36

In general, the annual statistics for each of the towers are similar. However, daily meteorology at each site varies considerably across the network. This has implications on transport and dispersion of pollutants, which is particularly important in atmospheric emergency release scenarios and dispersion modeling. Table 5-2 lists some of the extremes and variations found in meteorological measurements across SNL/NM.

\subsubsection{Wind Analysis}

Figure 5-2 portrays annual wind roses for three locations across SNL/NM. A wind rose is a graphical presentation of wind speed and direction frequency distribution. Wind direction is the true bearing when facing the wind (the direction from which the wind is blowing). As seen in the figures, wind directions and speeds can vary significantly across SNL/NM. Although not shown, the annual wind frequency distribution for TA-I shows a different pattern with the greatest direction frequency from the east and east-northeast, as winds blow from Tijeras Canyon. The annual predominant direction at most towers is produced by the 


\section{Extremes and Variations Across the CAN Network}

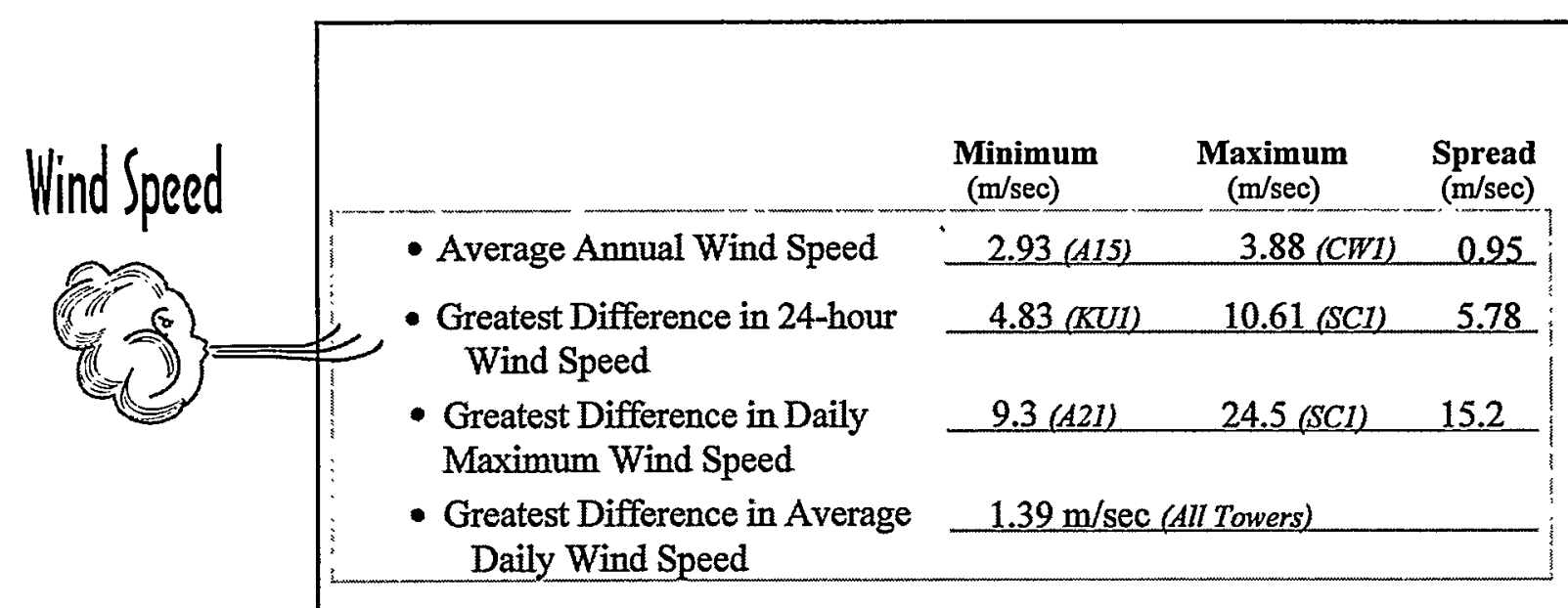

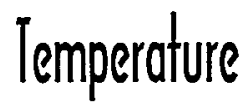
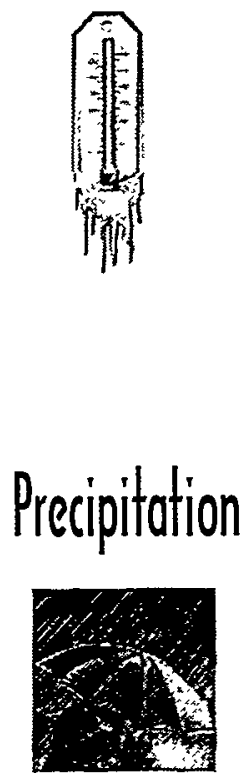

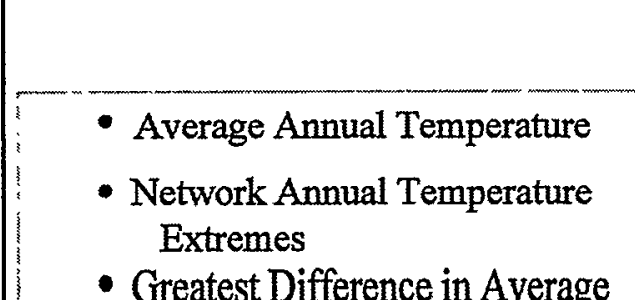

- Greatest Difference in Average

Daily Temperature

- Greatest Variation in Daily Minimum Temperature

- Greates Variation in Daily Maximum Temperature

$$
\underset{{ }^{\circ} \mathrm{C}}{\operatorname{Mrimimum}}
$$

${ }^{\circ} \mathrm{C}$

$12.6(\mathrm{SCI})$

13.2(A21)

0.6

$-15.3(S C 1)$

$36.8(\mathrm{CWI})$

52.1

\begin{tabular}{lll}
$5.1(A 15)$ & $9.5(M W 1) \quad 4.4$ \\
\hline
\end{tabular}

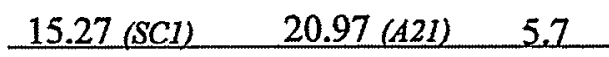

15.5 (A15)

$19.3(\mathrm{CWI})$

3.8

\section{Minimum}

(cm)

Maximum

$(\mathrm{cm})$

Spread

(cm)

- Annual Precipitation (Extremes) $\quad 33.71$ (A36) $\quad 48.89$ (SCI) $\quad 15.18$

- Daily Rainfall Variation

0

$3.15(A 36)$

3.15

- Greatest Monthly Precipitation Difference

- Greatest Extreme in Daily Rainfall

$2.01(A 36) \quad 10.10(S C I) \quad 8.09$

$3.55(\mathrm{SCI})$

NOTE: Tower locations are shown in parentheses.

Winter precipitation that falls as snow is underestimated (mostly at the $\mathrm{SC} 1$ tower). 


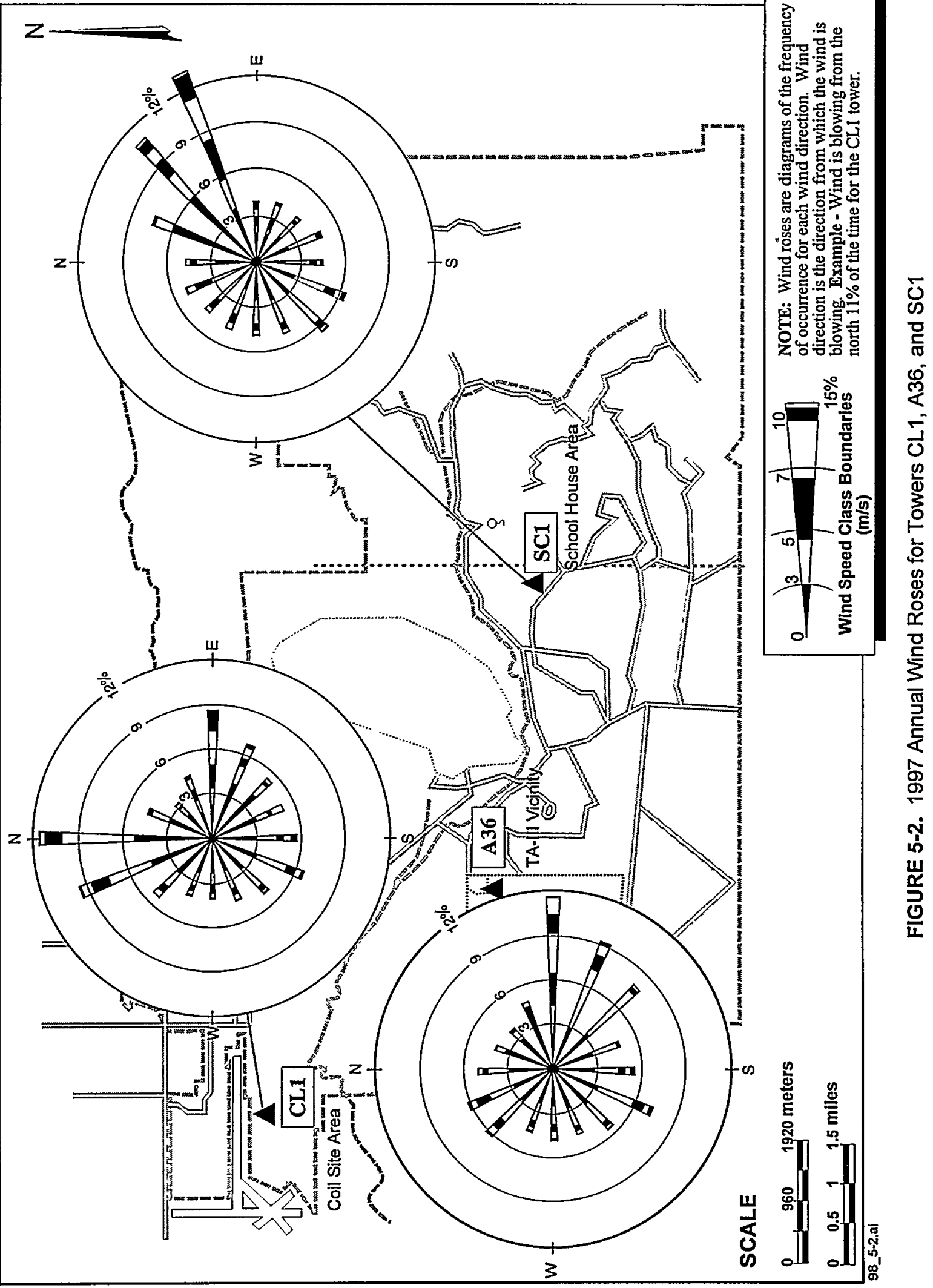


topographic influences that create nocturnal drainage flows (Figure 5-2).

A comparison of the A15 tower wind speed data with the rest of the network reveals building effects (urbanization) on wind speed; the large percentage of calms and very low wind speeds produces the slowest average annual wind speed as shown in table 5-2. In addition to the lower wind speeds, stability class frequency (not shown) is also effected by the variations in wind direction by flow around and over buildings. Completely lost in the annual frequency distribution is the diurnal pattern of wind flow common through many areas of SNL/NM. Figure 5-3 shows the day and night wind frequency distributions respectively for tower A36. In general, the closer to the mountains or canyons the greater the frequency of winds coming from the easterly directions at night. Daytime wind patterns are not quite as pronounced but generally flow toward the mountains or channel into the canyons.

\subsection{AMBIENT AIR SURVEILLANCE}

Ambient air surveillance, conducted within the CAN Program, is integral to compliance with 40 CFR 50, National Primary and Secondary Ambient Air Quality Standards, and 40 CFR 58, Ambient Air Quality Surveillance. Monitoring activities also follow DOE Order 5400.1 (DOE 1990a). A complete list of applicable air quality regulations is given in table 5-12 (Section 5.5).

The primary objective in gathering ambient air surveillance data is to establish background concentration levels for pollutants of concern, show compliance with the National Ambient Air Quality Standards (NAAQS) and local ambient air quality standards, and evaluate effects, if any, from SNL/NM's operations on the public and the environment.
Ambient air monitoring is performed at six locations with 10 monitors described briefly below and illustrated in figure 5-4.

- There is one criteria pollutant monitoring station (CPMS) in the network, located in the most populated area of SNL/NM. The CPMS performs continuous monitoring of sulfur dioxide $\left(\mathrm{SO}_{2}\right)$, carbon monoxide $(\mathrm{CO})$, nitrous oxides $\left(\mathrm{NO}_{\mathrm{X}}\right)$ and ozone $\left(\mathrm{O}_{3}\right)$. Data are then compiled into hourly averages. A particulate monitor is part of the CPMS and is used to collect data on lead $(\mathrm{Pb})$ concentrations.

- There are six particulate matter (PM) monitoring stations distributed throughout the site. PM with a diameter equal to or less than 10 microns $\left(\mathrm{PM}_{10}\right)$ is a criteria pollutant because it is an inhalation hazard. $\mathrm{PM}_{10}$ samples are collected over a 24-hour period starting and ending at midnight, every sixth day. This schedule is consistent with the National Air Sampling Program.

- Volatile organic compound (VOC) monitoring takes place at four stations. VOCs comprise the organic vapors given off by such chemicals as petroleum products and solvents. VOC samples are collected once a month over a 24-hour period.

\subsubsection{Ambient Air Monitoring Results}

\section{Criteria Pollutants}

The automated data recovery for criteria pollutants in 1997 was 89 percent. Criteria pollutants, as defined by the EPA, are sulfur dioxide $\left(\mathrm{SO}_{2}\right)$, carbon monoxide $(\mathrm{CO})$, nitrogen dioxide $\left(\mathrm{NO}_{2}\right)$, ozone $\left(\mathrm{O}_{3}\right), \mathrm{PM}_{10}$, and lead $(\mathrm{Pb})$. The CPMS station measures gaseous criteria pollutants and particulate lead. (The criteria pollutant, $\mathrm{PM}_{10}$, is measured at $\mathrm{PM}$ stations). Table 5-3 lists the state and federal ambient air quality standards for criteria pollutants and monitored results from the CPMS. 


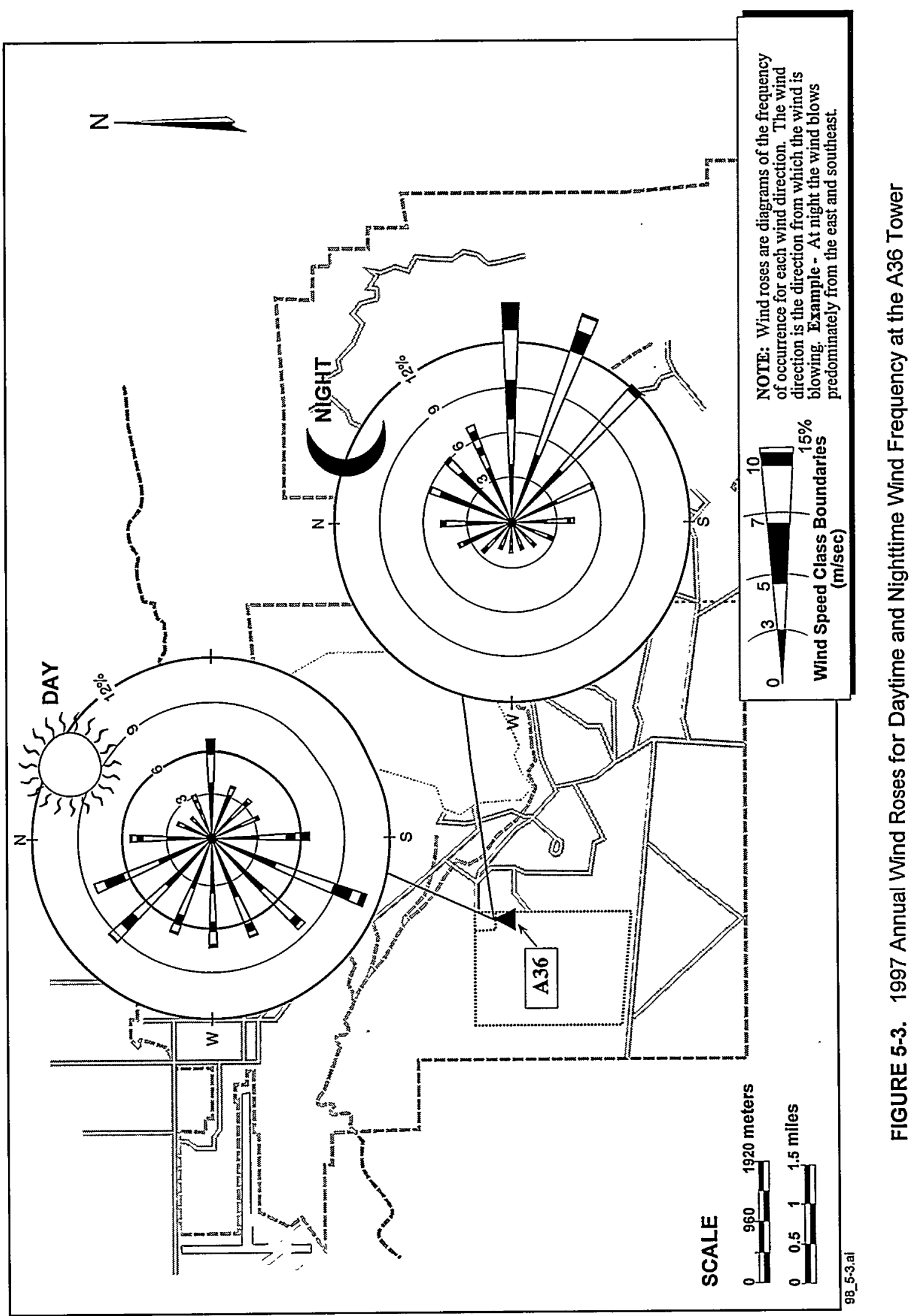




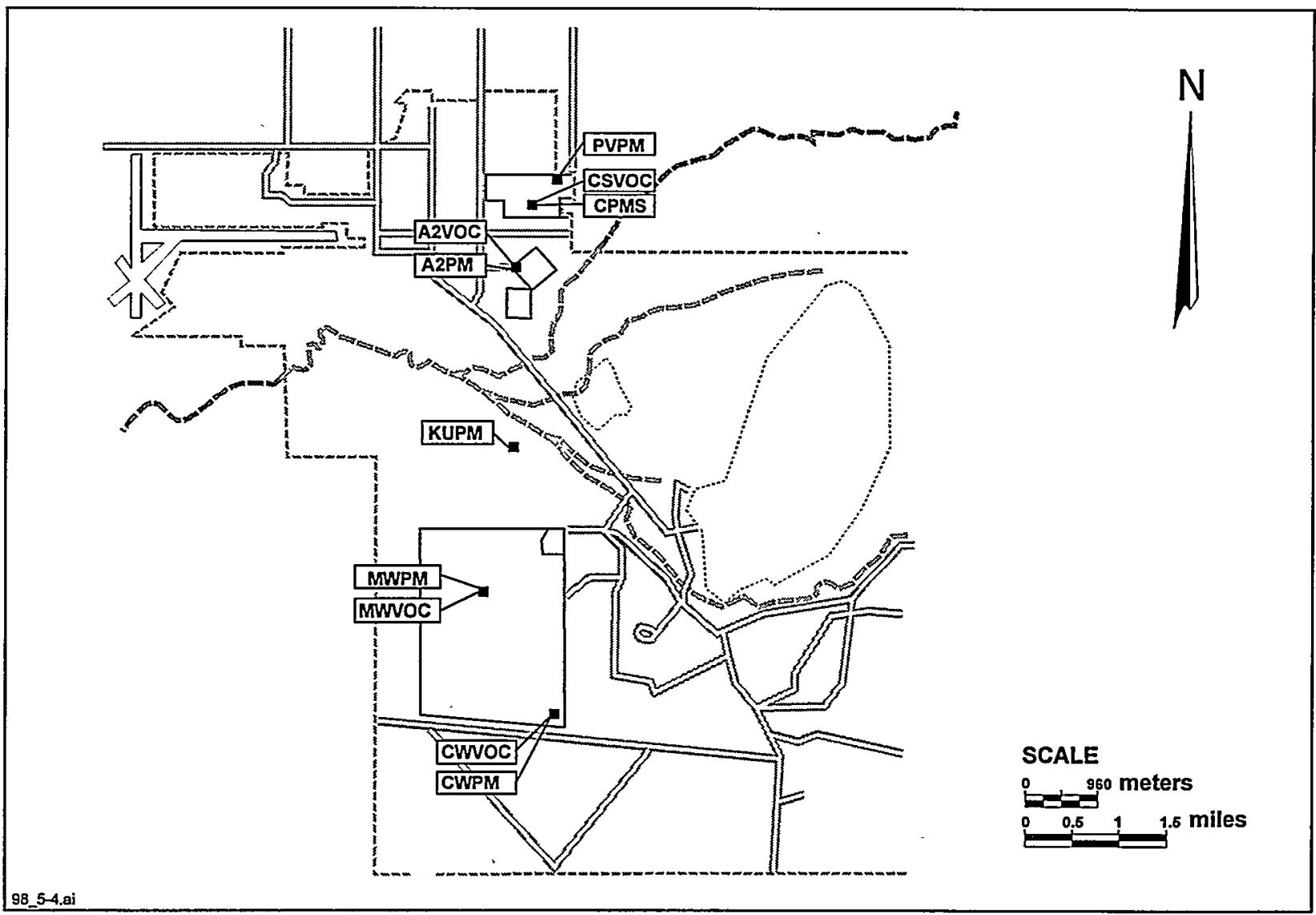

FIGURE 5-4. Ambient Air Monitoring Equipment Located at Six Stations Throughout the SNL/NM Site

Annual federal standards for criteria pollutants cannot be violated, however, exceedences of the short-term standards are allowable once a year. State standards also allow short-term exceedences due to meteorological conditions such as in the case of an atmospheric inversion where air mixing may be extremely restricted. There were no short-term exceedences or violations in 1997.

In 1997, the EPA reviewed several NAAQSs. The form of the standard for ozone was changed from an hourly standard of $0.120 \mathrm{ppm}$ to an 8 -hour standard of 0.080 . The fourth highest daily maximum may not exceed this value. A new standard was developed for PM to include particulates with a diameter less than or equal to $2.5 \mu \mathrm{m}$. Data gathering across the nation for this pollutant is scheduled to commence in 1998 .
Particulate Matter - $\mathbf{P M}_{10}$

Data recovery for $\mathrm{PM}_{10}$ was 98 percent complete based on the every-sixth-day sampling schedule. In general, 24-hour (daily) $\mathrm{PM}_{10}$ concentrations were quite low except for several days during the spring when gusty winds resuspended dust particles. The highest daily particulate loading $\left(38 \mu \mathrm{g} / \mathrm{m}^{3}\right)$ occurred at the A2PM site in March (Table 5-3). Table 5-4 lists the quarterly $\mathrm{PM}_{10}$ averages and the annual average at each location. The A2PM station had the highest annual loading for 1997 due to construction activities in the area. In general, sites furthest away from populated areas of SNL/NM show the lowest annual $\mathrm{PM}_{10}$ concentrations. There were no exceedences of federal or state standards for $\mathrm{PM}_{10}$ during 1997. 
TABLE 5-3. 1997 Criteria Pollutant Results as Compared to Regulatory Standards

\begin{tabular}{|c|c|c|c|c|c|}
\hline $\begin{array}{l}\text { Criteria } \\
\text { Pollutant }\end{array}$ & $\begin{array}{l}\text { Averaging } \\
\text { Time }\end{array}$ & Unit & $\begin{array}{l}\text { NMAQS } \\
\text { Standard }\end{array}$ & $\begin{array}{l}\text { NAAQS } \\
\text { Standard }\end{array}$ & $\begin{array}{l}\text { Yearly Summary of } \\
\text { Measured Concentrations }\end{array}$ \\
\hline \multirow[t]{2}{*}{ Carbon Monoxide } & 1 hour & ppm & 13.1 & 35 & 10.6 \\
\hline & 8 hours & ppm & 8.7 & 9 & 3.10 \\
\hline \multirow[t]{2}{*}{ Nitrogen Dioxide } & 24 hours & ppm & 0.10 & & 0.039 \\
\hline & Annual & ppm & 0.05 & 0.053 & 0.014 \\
\hline \multirow{3}{*}{ Sulfur Dioxide $\S$} & 3 hours & ppm & & 0.50 & 0.010 \\
\hline & 24 hours & ppm & 0.10 & 0.14 & \\
\hline & Annual & $\mathrm{ppm}$ & 0.02 & 0.03 & \\
\hline \multirow[t]{2}{*}{ Ozone } & 1 hour & $\mathrm{ppm}$ & 0.12 & 0.12 & 0.084 \\
\hline & 8 hour & ppm & & 0.080 & 0.064 \\
\hline \multirow[t]{2}{*}{$\mathbf{P M}_{10}$} & 24 hours & $\mu \mathrm{g} / \mathrm{m}^{3}$ & 150 & 150 & $38^{*}$ \\
\hline & Annual & $\mu \mathrm{g} / \mathrm{m}^{3}$ & & 50 & $11.95^{* *}$ \\
\hline \multirow{2}{*}{$\begin{array}{l}\text { Total Suspended } \\
\text { Particulates }\end{array}$} & 7 days & $\mu \mathrm{g} / \mathrm{m}^{3}$ & 110 & & N/A \\
\hline & 30 days & $\mu \mathrm{g} / \mathrm{m}^{3}$ & 90 & & N/A \\
\hline \multirow[t]{2}{*}{ Lead } & 30 days & $\mu \mathrm{g} / \mathrm{m}^{3}$ & & & 0.0019 \\
\hline & Any quarter & $\mu \mathrm{g} / \mathrm{m}^{3}$ & & 1.5 & 0.0006 \\
\hline
\end{tabular}

NOTE: $\mathrm{ppm}=$ parts per million; $\mu \mathrm{g} / \mathrm{m}^{3}=$ micrograms per cubic meter

N/A $=$ Not available

NMAQS $=$ New Mexico Air Quality Standards

NAAQS = National Ambient Air Quality Standards

$\S$ Standards are defined in $\mu \mathrm{g} / \mathrm{m}^{3}$ and have been converted to $\mathrm{ppm}$.

* Highest 24-hour particulate loading measured at the A2PM site in March 1997.

** Highest annual particulate loading measured at the A2PM site.

Table 5-5 shows the types of radiological and nonradiological analyses conducted on samples collected at each $\mathrm{PM}_{10}$ station. PM samples are analyzed for 20 metals and four radiological determinations. Filters are consolidated into monthly composites for the analyses. Monthly composites varied from four to six filters per month throughout 1997 depending on the sampling schedule and some missed samples (for example, monthly composites for two months contained four instead of five filters due to missed samples). Analyses are conducted by an EPA-approved offsite laboratory. The laboratory results for the samples are subtracted from the monthly blank analysis. The final analytical results are averaged over the year (Table 5-6) and compared to threshold limit values (TLVs) as a reference using time weighted averages (TWAs).

The $\mathrm{PM}_{10}$ analytical results are generally consistent with metals found in local soil analyses at SNL/NM. As can be seen from table $5-6$, beryllium, as a total metal, was not found above the detection limit-but it was found in the gamma analysis. All radiochemistry data are used in the averaging routine for reporting, regardless of the detection limit for that specific sample. This generally produces more conservative (higher total) concentrations. 
TABLE 5-4. Quarterly and Annual Averages of $\mathrm{PM}_{10}$ at SNL/NM for 1997

\begin{tabular}{|l|r|r|r|r|r|}
\hline Station & $\begin{array}{l}\text { Jan-Mar } \\
\left(\mu \mathrm{g} / \mathrm{m}^{3}\right)\end{array}$ & $\begin{array}{l}\text { Apr-Jun } \\
\left(\mu \mathrm{g} / \mathrm{m}^{3}\right)\end{array}$ & $\begin{array}{l}\text { Jul-Sep } \\
\left(\mu \mathrm{g} / \mathrm{m}^{3}\right)\end{array}$ & $\begin{array}{l}\text { Oct-Dec } \\
\left(\mu \mathrm{g} / \mathrm{m}^{3}\right)\end{array}$ & $\begin{array}{l}\text { Annual } \\
\left(\mu \mathrm{g} / \mathrm{m}^{3}\right)\end{array}$ \\
\hline A2PM & 13.73 & 11.60 & 11.40 & 11.38 & 12.03 \\
\hline CPMS & 10.95 & 12.73 & 11.67 & 11.97 & 11.83 \\
\hline CWPM & 7.87 & 10.33 & 8.20 & 8.67 & 8.77 \\
\hline KUPM & 8.47 & 11.40 & 10.33 & 9.53 & 9.93 \\
\hline MWPM & 8.57 & 11.67 & 9.80 & 7.93 & 9.49 \\
\hline PVPM & 11.33 & 12.53 & 11.47 & 12.67 & 12.00 \\
\hline
\end{tabular}

TABLE 5-5. $\mathrm{PM}_{10}$ Sample Analyses Conducted at the Five PM Monitors and the CPMS Site

\begin{tabular}{|l|c|l|c|c|c|}
\hline Station & ICP Metals & $\begin{array}{l}\text { Total } \\
\text { Uranium }\end{array}$ & $\begin{array}{l}\text { Gamma } \\
\text { Spectroscopy }\end{array}$ & $\begin{array}{l}\text { Gross } \\
\text { Alpha }\end{array}$ & $\begin{array}{l}\text { Gross } \\
\text { Beta }\end{array}$ \\
\hline PVPM & $\checkmark$ & & $\checkmark$ & $\checkmark$ & $\checkmark$ \\
\hline CWPM & $\checkmark$ & & $\checkmark$ & $\checkmark$ & $\checkmark$ \\
\hline A2PM & $\checkmark$ & & $\checkmark$ & $\checkmark$ & $\checkmark$ \\
\hline KUPM & $\checkmark$ & $\checkmark$ & $\checkmark$ & $\checkmark$ & $\checkmark$ \\
\hline MWPM & $\checkmark$ & $\checkmark$ & $\checkmark$ & $\checkmark$ & $\checkmark$ \\
\hline CPMS & (lead only) & -- & -- & - & -- \\
\hline
\end{tabular}

NOTE: $\mathrm{PM}_{10}=$ particulate matter (diameter equal to or less than 10 microns). ICP = inductively coupled plasma (method). 
TABLE 5-6. $\mathrm{PM}_{10}$ Average Annual Metals Concentration by Station Location

\begin{tabular}{|c|c|c|c|c|c|c|c|c|}
\hline Analyte & Units & A2PM & CWPM & KUPM & MWPM & PVPM & CPMS $^{*}$ & $\mathrm{TLV}^{\star *}$ \\
\hline \multicolumn{9}{|l|}{ Metals } \\
\hline Aluminum & $\mu \mathrm{g} / \mathrm{m}^{3}$ & 0.0678 & 0.0586 & 0.0635 & 0.0640 & $0.055 ़ 7$ & & 2,000 \\
\hline Barium & $\mu \mathrm{g} / \mathrm{m}^{3}$ & 0.0037 & 0.0025 & 0.0039 & 0.0045 & 0.0043 & & 50 \\
\hline Beryllium & $\mu \mathrm{g} / \mathrm{m}^{3}$ & 0.0000 & 0.0000 & 0.0000 & 0.0000 & 0.0000 & & 2 \\
\hline Calcium & $\mu \mathrm{g} / \mathrm{m}^{3}$ & 0.1670 & 0.0850 & 0.0911 & 0.0899 & 0.1423 & & 10 \\
\hline Chromium & $\mu \mathrm{g} / \mathrm{m}^{3}$ & 0.0002 & 0.0001 & 0.0001 & 0.0001 & 0.0002 & & 1 \\
\hline Cobalt & $\mu \mathrm{g} / \mathrm{m}^{3}$ & 0.0000 & 0.0000 & 0.0000 & 0.0000 & 0.0000 & & 20 \\
\hline Copper & $\mu \mathrm{g} / \mathrm{m}^{3}$ & 0.0106 & 0.0089 & 0.0107 & 0.0082 & 0.0102 & & 1,000 \\
\hline Iron & $\mu \mathrm{g} / \mathrm{m}^{3}$ & 0.0829 & 0.0564 & 0.0644 & 0.0619 & 0.0779 & & 5,000 \\
\hline Lead & $\mu \mathrm{g} / \mathrm{m}^{3}$ & 0.0000 & 0.0000 & 0.0000 & 0.0000 & 0.0000 & 0.0001 & 150 \\
\hline Magnesium & $\mu \mathrm{g} / \mathrm{m}^{3}$ & 0.0269 & 0.0229 & 0.0310 & 0.0323 & 0.0213 & & 10,000 \\
\hline Manganese & $\mu \mathrm{g} / \mathrm{m}^{3}$ & 0.0024 & 0.0017 & 0.0018 & 0.0018 & 0.0021 & & 200 \\
\hline Nickel & $\mu \mathrm{g} / \mathrm{m}^{3}$ & 0.0000 & 0.0001 & 0.0001 & 0.0000 & 0.0001 & & 50 \\
\hline Potassium & $\mu \mathrm{g} / \mathrm{m}^{3}$ & 0.0414 & 0.0356 & 0.0548 & 0.0461 & 0.0411 & & $\overline{\mathrm{NA}}$ \\
\hline Silicon & $\mu \mathrm{g} / \mathrm{m}^{3}$ & 0.0581 & 0.0302 & 0.0149 & 0.0458 & 0.0219 & & 10,000 \\
\hline Silver & $\mu \mathrm{g} / \mathrm{m}^{3}$ & 0.0000 & 0.0000 & 0.0000 & 0.0000 & 0.0000 & & 10 \\
\hline Sodium & $\mu \mathrm{g} / \mathrm{m}^{3}$ & 0.7167 & 0.4278 & 0.9554 & 0.8447 & 0.5371 & & 5,000 \\
\hline$\overline{\text { Zinc }}$ & $\mu \mathrm{g} / \mathrm{m}^{3}$ & 0.0037 & 0.0021 & 0.0022 & 0.0017 & 0.0050 & & 10 \\
\hline Analyte & Units & A2PM & CWPM & KUPM & MWPM & PVPM & CPMS $^{*}$ & TLV $^{\star *}$ \\
\hline \multicolumn{9}{|l|}{ Radionuclides } \\
\hline Gross Alpha & $\mathrm{pCi} / \mathrm{m}^{3}$ & 0.0180 & 0.0139 & 0.0187 & 0.0134 & 0.0148 & & $\overline{\mathrm{NA}}$ \\
\hline Gross Beta & $\mathrm{pCi} / \mathrm{m}^{3}$ & 0.0037 & 0.0022 & 0.0054 & 0.0031 & 0.0060 & & $\mathrm{NA}$ \\
\hline Beryllium-7 & $\mathrm{pCi} / \mathrm{m}^{3}$ & $\overline{0.1346}$ & 0.1463 & 0.1466 & 0.1505 & 0.1336 & & NA \\
\hline Potassium-40 & $\mathrm{pCi} / \mathrm{m}^{3}$ & 0.0221 & 0.0053 & 0.0180 & 0.0154 & 0.0441 & & 200 \\
\hline UTOT & $\mu \mathrm{g} / \mathrm{m}^{3}$ & & & 0.0000 & 0.0000 & & & $\overline{N A}$ \\
\hline
\end{tabular}

NOTE: TLV = threshold limit value. The TLV is a guideline to assist in the control of health hazards. TLVs are not legal standards.

NA $=$ not available

* The PM monitor at the CPMS measures only particulate $\mathrm{Pb}$ concentrations.

${ }^{* *}$ Values listed are time-weighted averages (TWAs). TWA is the concentration for a normal 8-hour work day and 40-hour week, to which nearly all workers may be exposed without adverse effect. 
Due to the low averages, a relatively small variation between the sites may be misinterpreted as a significant difference. An analysis of variance was performed to determine if concentrations of any analyte were statistically and significantly different at any site. Results of this variance test showed there were no statistically significant differences in concentrations of any analyte in 1997.

\section{Volatile Organic Compounds (VOCs)}

Data recovery for all VOC monitoring was 98 percent. The July sample from the CWL was excluded from this analysis. A review of the laboratory results for this sample revealed a 2.5 order of magnitude outlier for the total nonmethane hydrocarbon (TNMHC) concentration and increased detection limits for the speciated compounds. The increase in detection limits produced values that were below the elevated detection limits for 94 percent of the speciated compounds. These two criteria warranted the exclusion of the sample in the annual results.

Monthly VOC samples were analyzed for 31 VOC species and TNMHC. Monthly results for compounds detected are reported as averaged concentrations shown in table 5-7. These averages are not annual averages due to the method of including the sample only if the compound is detected. This type of averaging is done to prevent diluting the reported average.

The VOCs generally observed at SNL/NM are products or by-products of fossil fuels or found in solvents. An analysis of variance was performed on the monthly results to determine if VOC concentrations of any analyte were statistically and significantly different compared to other sites.

Landfills - A statistically significant site for 1,1,1-trichloroethane (1,1,1-TCA) is the Mixed Waste Landfill (MWL). Elevated concentrations have been noted seasonally since May 1995, after several exploratory wells were drilled around the MWL during ER characterization studies. Since that time, concentrations of 1,1,1-TCA have increased in the summer and decreased in the winter. The winter levels are still higher than the maximum concentrations at other locations. However, each year the maximum summer concentration is less than the previous year.

CPMS Site - Excluding the large concentration of 1,1,1-TCA at the MWL, additional comparisons of VOC sampling sites revealed statistically higher concentrations for several compounds measured at the CPMS site. Xylene and benzene compounds were found to be significant with slightly higher concentrations than other locations. All of these compounds are associated with fossil fuels. The monitoring station is located at a busy intersection and is across the street from the motor pool where vehicle maintenance is performed. Given this location, CPMS VOC concentrations are expected to be higher than the rest of the monitoring sites.

\section{Radiological air EMISSIONS NATIONAL EMISSION STANDARDS FOR HAZARDOUS AIR POLLUTANTS (NESHAP) COMPLIANCE}

The NESHAP Program is conducted by the Environmental and Emergency Management Department. . NESHAP compliance support is provided to all SNL/NM source owners subject to radionuclide air emissions regulations. The EPA regulates radionuclide air emissions in accordance with 40 CFR 61, Subpart H, National Emission Standards for Emissions of Radionuclides Other than Radon from Department of Energy Facilities. Dose is calculated using the Clean Air Act Assessment Package-1988 (CAP88) computer code (EPA 1995). Only facilities with air emissions contributing a dose greater than $0.1 \mathrm{mrem} / \mathrm{yr}$ are used in the CAP88 calculations. 
TABLE 5-7. VOC Average Concentration by Station Location Compiled from Monthly Results These averages are not true annual averages due to the method of including the sample only if the compound is detected.

\begin{tabular}{|c|c|c|c|c|c|}
\hline Compound & $\begin{array}{l}\text { CPMS } \\
\text { (ppbv) }\end{array}$ & $\begin{array}{c}\text { CWL } \\
\text { (ppbv) }\end{array}$ & $\begin{array}{c}\text { MWL } \\
\text { (ppbv) }\end{array}$ & $\begin{array}{c}\text { TA-II } \\
\text { (ppbv) }\end{array}$ & $\begin{array}{l}\mathrm{TLV}^{*} \\
\text { (ppb) }\end{array}$ \\
\hline 1,1,1-Trichloroethane & 0.11645 & 0.1792 & 18.72333 & 0.126158 & 350,000 \\
\hline 1,4-Dioxane & 0.491 & & 0.24 & & 25,000 \\
\hline 1-Butene/Isobutene & 0.28854 & 0.42145 & 0.1787 & 0.240378 & $\mathrm{NA}$ \\
\hline 1,2-Dichloroethane & 0.0359 & 0.0394 & 0.112 & 0.0279 & 10,000 \\
\hline 2,2,4-Trimethylpentane & 0.230208 & 0.360373 & 0.060255 & 0.143818 & NA \\
\hline 2-Butanone & 0.4806 & 2.265932 & 0.329271 & 0.518614 & 200,000 \\
\hline 3-Methylpentane & 0.278473 & 0.158614 & 0.1127 & 0.193545 & $\mathrm{NA}$ \\
\hline Acetone & 7.505833 & 28.64636 & 6.297273 & 6.69 & 750,000 \\
\hline Benzene & 0.55205 & 0.1443 & 0.1721 & 0.308417 & 300 \\
\hline Carbon tetrachloride & 0.100875 & 0.098764 & 0.1094 & 0.094383 & 5,000 \\
\hline Chlorobenzene & 0.0688 & 0.057933 & 0.060157 & 0.055783 & 10,000 \\
\hline Chloromethane & 0.501727 & 0.484 & 0.483182 & 0.487727 & 5,000 \\
\hline Cis/trans-4-Methyl-2-Pentene & 0.0103 & & & & N/A \\
\hline Dichlorodifluoromethane & 0.5955 & 0.522636 & 0.551083 & 0.54875 & $1,000,000$ \\
\hline Ethylbenzene & 0.170264 & 0.057486 & 0.062256 & 0.11958 & 100,000 \\
\hline Halocarbon 113 & 0.097392 & 0.130445 & 0.0981 & 0.100233 & NA \\
\hline Isobutene & 0.196 & 0.694 & & 0.144 & NA \\
\hline Isohexane & 0.45425 & 0.2425 & 0.149309 & 0.288125 & NA \\
\hline Isopentane & 1.698833 & 5.0291 & 2.374417 & 2.508833 & 600,000 \\
\hline $\mathrm{m} / \mathrm{p}$-Xylene & 0.355364 & 0.108522 & 0.1379 & 0.24781 & $\mathrm{NA}$ \\
\hline Methylene chloride & 0.34375 & 1.072278 & 0.344333 & 0.94819 & 50,000 \\
\hline Methylisobutylketone & 0.09895 & 2.13 & 0.111375 & 0.17564 & 50,000 \\
\hline n-Butane & 1.50775 & 0.576 & 0.65285 & 1.08775 & 800,000 \\
\hline n-Hexane & 0.344736 & 0.154227 & 0.15398 & 0.309582 & 50,000 \\
\hline n-Pentane & 0.86675 & 1.36 & 0.636283 & 0.829 & 600,000 \\
\hline n-Undecane & 0.019458 & 0.042225 & 0.026025 & 0.13235 & $\mathrm{NA}$ \\
\hline o-Dichlorobenzene & 0.0721 & 0.02255 & & 0.03305 & 25,000 \\
\hline o-Xylene & 0.18002 & 0.061213 & 0.077667 & 0.106388 & 100,000 \\
\hline Tetrachloroethene & 0.11155 & 0.185244 & 0.11603 & 0.114078 & $\mathrm{NA}$ \\
\hline Toluene & 0.924083 & 0.4271 & 0.297108 & 1.28835 & 50,000 \\
\hline Trichloroethene & 0.064818 & 0.188956 & 0.063013 & 0.144316 & $\mathrm{NA}$ \\
\hline Trichlorofluoromethane & 0.27075 & 0.262 & 0.254167 & 0.2785 & $1,000,000^{* *}$ \\
\hline TNMHC & 34.675 & 31.27364 & 26.02417 & 34.43 & NA \\
\hline
\end{tabular}

NOTE: The analytical laboratory refined the equipment used for analyses during the year, resulting in better speciation of compounds. For this reason compounds are included separately and in combination with another analyte in the table.

TNMHC $=$ total non-methane hydrocarbons

$\mathrm{TLV}=$ threshold limit value. The TLV is a guideline to assist in the control of health hazards.

TLVs are not legal standards.

$\mathrm{NA}=$ not available

*Values listed are time-weighted averages (TWAs) except where marked. TWA is the concentration for a normal 8-hour work day and 40-hour week, to which nearly all workers may be exposed without adverse effect.

** Short-term exposure limit (STEL) is a 15-minute TWA not to be exceeded at any time during the work day. 
The EPA has set a maximum individual public dose limit of $10 \mathrm{mrem} / \mathrm{yr}$ resulting from the combined radiological emissions produced from any DOE facility. The average dose (nationwide) a person receives from all radioactive sources-natural and manmade-is 360 $\mathrm{mrem} / \mathrm{yr}$. The bulk of this dose comes from natural sources such as natural background radon (53 percent), radioactive elements within the body (11 percent), and cosmic radiation ( 8 percent).

\section{Compliance Reporting}

The NESHAP Annual Report for CY 1997 was submitted to the EPA, as required, by June 30, 1998 (SNL 1998b). The report contains listed radionuclide emissions from each of SNL/NM's 15 NESHAP facilities (Figure 5-5) and a summary of the dose assessment results (discussed in section 5.4). The annual report is also submitted to the DOE. A more comprehensive supplemental document detailing facility emission factors, demographic data, and dose assessment calculations is available to the EPA and the DOE upon request (SNL 1998b). Other NESHAP program documents are listed in table 5-13 at the end of this chapter.

Radionuclide emissions are described as either point or diffuse sources. Point sources are produced from an exhaust stack or vent, while diffuse sources emanate from broad areas of contamination, such as radionuclidecontaminated soils present at an Environmental Restoration (ER) site. Table 5-8 lists the radionuclide species and total curies released from each SNL/NM NESHAP source. In 1997, there were a total of 14 point sources and one diffuse source listed in the NESHAP report. Although, two of these sources reported zero releases in 1997.

\section{Facility Evaluation}

NESHAP regulation stipulates that direct stack or diffuse monitoring is only required if a facility has the potential to produce an effective dose equivalent (EDE) to the maximally exposed individual (MEI) of greater than 0.1 mrem/yr. Currently, there are no facilities with this potential and, therefore, no stack monitoring is required at SNL/NM. However, while not required by regulation, stack monitoring and calculations based on measured parameters are performed as a Best Management Practice at several facilities. All emissions based on measurements (i.e., continuous monitoring, periodic monitoring, and calculations based on measured parameters) are used to calculate the doses (see section 5.4).

Facilities with measurable releases that result in an EDE to the MEI of less than $0.1 \mathrm{mrem} / \mathrm{yr}$ do not require monitoring and are not required for calculating NESHAP emissions. These facilities, however, are required to be listed in the NESHAP Annual Report for CY1997 (SNL 1998b). There are currently seven facilities at SNL/NM that fall into this category. These sources estimate their potential radionuclide air emissions based on worst-case calculations.

In 1997, the highest activities found in SNL/NM's atmospheric emissions were primarily the result of argon and tritium. Historically, these are the radionuclides that have generally been the most significant releases over the past 10 years. Figure 5-6 summarizes the annual release in curies from these species since 1988.

\section{TA-I Sources}

There were six radionuclide air emission sources in TA-I in 1997. Emissions from only one facility were used in the CAP88 calculation:

- The Metal Tritide Laboratory conducts research on tritium materials. Tritium was the only radionuclide released.

- The Calibration Laboratory calibrates radiation detection equipment. Tritium was the only radionuclide released.

- The Radiation Laboratory conducts smallscale experiments. It released air-activation products and tritium. 


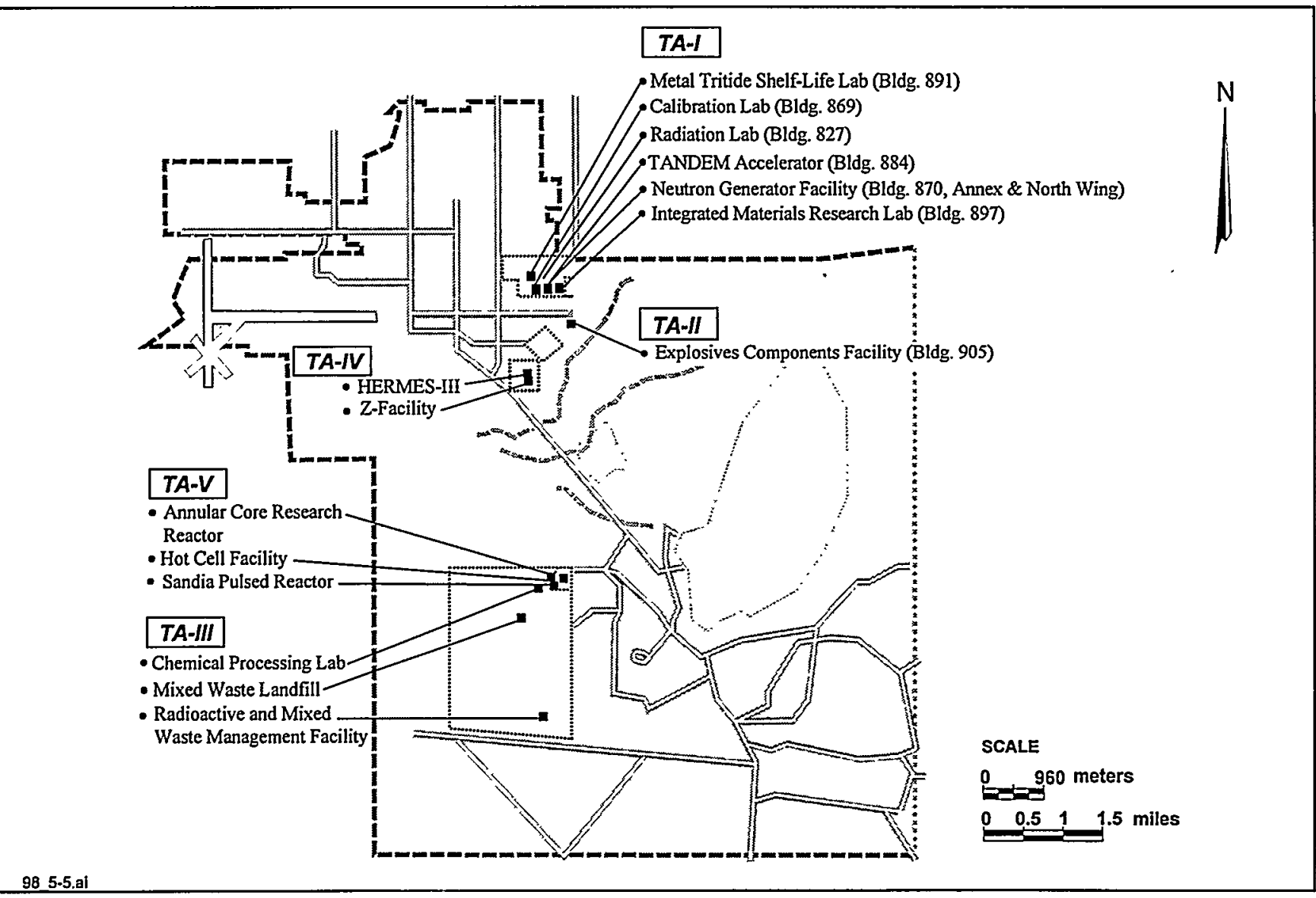

FIGURE 5-5. Locations of the 15 NESHAP Facilities at SNL/NM that Reported Radionuclide Releases in 1997

- The Tandem Accelerator is an ion solid interaction and defect physics accelerator facility. Reported emissions included air activation products, fluorine, and tritium.

- The Neutron Generator Facility (NGF) is the principal production facility of neutron generators used in nuclear weapons. This facility currently emits only tritium. The facility has two stacks: the Principal Production Facility East Annex and the Tritium Envelope North Wing. NGF emission results were used in CAP88 calculations.

- The Integrated Materials Research Laboratory (IMRL) is used for research and development of new and superior materials for government and industrial needs.
Carbon-14 was the only emission released from this facility.

\section{TA-II Sources}

In 1997, one source reported NESHAP emissions from TA-II:

The Explosive Components Facility (ECF) conducts destructive testing on neutron generators. The ECF reported releases of tritium.

\section{TA-III Sources}

Three facilities in TA-III reported NESHAP emissions in 1997:

- The Radioactive and Mixed Waste Management Facility (RMWMF) handles LLW and MW. During 1997, the RMWMF 


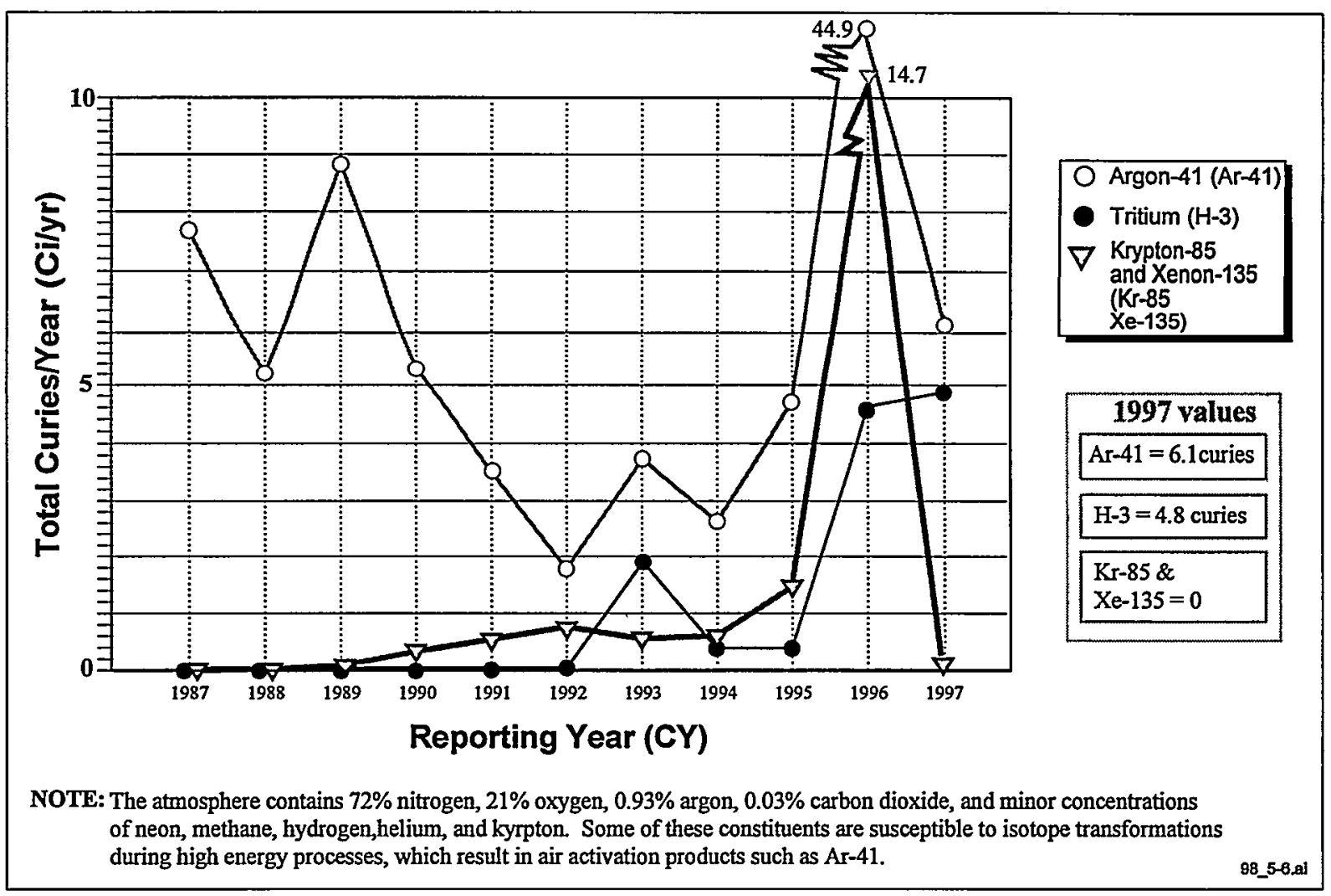

FIGURE 5-6. Summary of Atmospheric Releases of the Most Prevalent Airborne Radionuclides from SNL/NM Facilities Since 1987

reported only tritium releases. RMWMF emission results were used in CAP88 calculations.

- The Chemical Processing Laboratory located west of TA-V, is used to perform small-scale laboratory experiments. In 1997, the facility reported emissions of sodium-22, plutonium-241, americium-241, and uranium-232.

- The Mixed Waste Landfill (MWL) is a source of diffuse tritium contamination. In 1992 and 1993, two special studies were conducted to measure the flux of diffuse tritium emissions (Radian 1994). As conditions at this landfill have remained unchanged, the measured flux is assumed to remain fairly constant. The flux value is used to estimate the annual NESHAP emissions. Emission results were used in CAP88 calculations.

\section{TA-IV Sources}

There are two NESHAP facilities in TA-IV. Only one reported NESHAP emissions:

- The High-Energy Radiation Megavolt Electron Source-III (HERMES-III) accelerator is used to test the effects of prompt radiation from a nuclear burst on electronics and complete military systems. 
TABLE 5-8. Summary of Radionuclide Releases From the 15 NESHAP Sources in 1997

\begin{tabular}{|c|c|c|c|c|c|}
\hline Facility Name & $\begin{array}{l}\text { Tech } \\
\text { Area }\end{array}$ & $\begin{array}{l}\text { Monitoring } \\
\text { Method }\end{array}$ & $\begin{array}{l}\text { Modeling } \\
\text { Status }\end{array}$ & $\begin{array}{l}\text { Radionuclides } \\
\text { Emitted }\end{array}$ & $\begin{array}{c}\text { Release } \\
\text { (Ci/yr) }\end{array}$ \\
\hline $\begin{array}{l}\text { Annular Core Research Reactor } \\
\text { (ACRR), Bldg. } 6588\end{array}$ & $\mathrm{TA}-\mathrm{V}$ & Periodic & CAP88 & Ar-41 & $2.0 \times 10^{-4}$ \\
\hline $\begin{array}{l}\text { Sandia Pulsed Reactor (SPR), } \\
\text { Bldg. } 6590\end{array}$ & TA-V & Calculation & CAP88 & Ar-41 & 6.11 \\
\hline $\begin{array}{l}\text { - Hot Cell Facility (HCF), } \\
\text { Bldg. } 6580\end{array}$ & $\mathrm{TA}-\mathrm{V}$ & Periodic & $\begin{array}{l}\text { Not } \\
\text { modeled }\end{array}$ & none & 0 \\
\hline $\begin{array}{l}\text { High-Energy Radioactive } \\
\text { Megavolt Electron Source } \\
\text { (HERMES III), Bldg. } 970 \\
\end{array}$ & TA-IV & Periodic & CAP88 & $\begin{array}{l}N-13 \\
\text { O-15 }\end{array}$ & $\begin{array}{l}6.55 \times 10^{-4} \\
6.55 \times 10^{-5}\end{array}$ \\
\hline $\begin{array}{l}\text { Z-Facility, formerly the Particle } \\
\text { Beam Fusion Accelerator (PBFA- } \\
\text { II), Bldg. } 983\end{array}$ & TA-IV & Calculation & $\begin{array}{l}\text { Not } \\
\text { modeled }\end{array}$ & none & 0 \\
\hline $\begin{array}{l}\text { Mixed Waste Landfill (MWL) } \\
\text { (Diffuse emissions) }\end{array}$ & TA-III & Periodic & CAP88 & Tritium & $2.94 \times 10^{-1}$ \\
\hline $\begin{array}{l}\text { Chemical Processing Laboratory, } \\
\text { Bldg. } 6600\end{array}$ & TA-III & Calculation & $\begin{array}{l}\text { Not } \\
\text { modeled }\end{array}$ & $\begin{array}{l}\mathrm{Na}-22 \\
\mathrm{Am}-241 \\
\mathrm{U}-232 \\
\mathrm{Pu}-241\end{array}$ & $\begin{array}{l}2.4 \times 10^{-12} \\
1.0 \times 10^{-13} \\
1.0 \times 10^{-13} \\
1.0 \times 10^{-13}\end{array}$ \\
\hline $\begin{array}{l}\text { Radioactive and Mixed Waste } \\
\text { Management Facility (RMWMF), } \\
\text { Bldg. } 6920\end{array}$ & TA-III & Periodic & CAP88 & Tritium & 2.203 \\
\hline $\begin{array}{l}\text { Explosive Components Facility } \\
\text { (ECF)*, Bldg. } 905\end{array}$ & TA-II & Calculation & $\begin{array}{l}\text { Not } \\
\text { modeled }\end{array}$ & Tritium & $7.5 \times 10^{-4}$ \\
\hline $\begin{array}{ll}\text { Integrated Materials Research } \\
\text { Laboratory (IMRL), Bldg. } 897\end{array}$ & TA-I & Calculation & $\begin{array}{l}\text { Not } \\
\text { modeled }\end{array}$ & C-14 & $3.07 \times 10^{-5}$ \\
\hline $\begin{array}{l}\text { Neutron Generator Facility (NGF) } \\
\text { - East Annex, Bldg. } 870 \\
\text { - North Wing Tritium Envelope, } \\
\text { Bldg. } 870\end{array}$ & TA-I & Calculation & CAP88 & $\begin{array}{l}\text { Tritium } \\
\text { Tritium }\end{array}$ & $\begin{array}{l}1.14 \times 10^{-1} \\
2.215\end{array}$ \\
\hline $\begin{array}{l}\text { TANDEM Accelerator, } \\
\text { Bldg. } 884\end{array}$ & TA-I & Calculation & $\begin{array}{l}\text { Not } \\
\text { modeled }\end{array}$ & $\begin{array}{l}\text { Tritium } \\
\text { C-11 } \\
\text { N-13 } \\
\text { O-14 } \\
\text { O-15 } \\
\text { O-17 } \\
\text { F-18 }\end{array}$ & $\begin{array}{l}1.0 \times 10^{-6} \\
3.7 \times 10^{-3} \\
5.6 \times 10^{-5} \\
1.4 \times 10^{-7} \\
1.6 \times 10^{-2} \\
5.6 \times 10^{-4} \\
3.6 \times 10^{-5}\end{array}$ \\
\hline $\begin{array}{l}\text { Radiation Laboratory, } \\
\text { Bldg. } 827\end{array}$ & TA-I & Calculation & $\begin{array}{l}\text { Not } \\
\text { modeled }\end{array}$ & $\begin{array}{l}\text { Tritium } \\
\mathrm{N}-16 \\
\mathrm{~N}-13 \\
\mathrm{Ar}-41\end{array}$ & $\begin{array}{l}1.0 \times 10^{-5} \\
2.0 \times 10^{-7} \\
1.0 \times 10^{-8} \\
1.0 \times 10^{-9}\end{array}$ \\
\hline $\begin{array}{l}\text { Metal Tritide Shelf-Life } \\
\text { Laboratory, Bldg. } 891\end{array}$ & TA-I & Calculation & $\begin{array}{l}\text { Not } \\
\text { modeled }\end{array}$ & Tritium & $5.0 \times 10^{-9}$ \\
\hline - Calibration Laboratory, Bldg. 869 & TA-I & Calculation & $\begin{array}{l}\text { Not } \\
\text { modeled }\end{array}$ & Tritium & $1.99 \times 10^{-4}$ \\
\hline
\end{tabular}


This facility produces air activation products, primarily nitrogen-13 and oxygen15. Emissions results were used in CAP88 calculations.

- The Z-Facility is used for research on light ion inertial confinement fusion. The $Z$ Facility was formerly called the Particle Beam Fusion Accelerator (PBFA). Although the name has changed, its activities have remained essentially the same. In 1997, the facility operated under the energy threshold required to produce air activation products and, therefore, reported zero NESHAP emissions for the year.

\section{TA-V Sources}

There are three NESHAP sources in TA-V. Two facilities had reportable NESHAP emissions:

- The Annular Core Research Reactor (ACRR) is used to perform in-pile experiments for severe reactor accident research projects. In 1997, the configuration was converted to support the Medical Isotope Production Project (MIPP), which will produce radio-pharmaceuticals. Argon-41, an air activation product, was the only reported release. Emission results were used in CAP88 calculations.

- The Hot Cell Facility (HCF) provides full capability to remotely handle and analyze radioactive materials such as irradiated targets. There were no reportable NESHAP emissions in 1997.

- The Sandia Pulsed Reactor (SPR) is used to produce intense neutron bursts for effects testing on materials and electronics. The SPR emitted argon-41. This facility had the highest reported release in 1997. Emission results were used in CAP88 calculations.

\subsection{ASSESSMENT OF POTENTIAL DOSE TO THE PUBLIC}

In general, the dose received by a person is dependent on the distance from the sources, various pathways in the environment (food chain, air, and water), radionuclide half-lives and activities, and meteorological conditions. Historically, radioactive releases from SNL/NM have been, and continue to be, several orders of magnitude below the EPA's maximum allowable standard of $10 \mathrm{mrem} / \mathrm{yr}$. Radiation protection standards specific to DOE facilities are given in Appendix A.

\section{Dose Calculation}

To assess compliance, NESHAP facilities at SNL/NM must submit facility emission data to the NESHAP Program Administrator for input to dose assessment modeling. All dose calculation results presented in this section were obtained using the EPA CAP88 computer code (EPA 1995).

Emission release parameters include stack height, stack diameter, and exhaust velocity. The resulting dose calculation determines the effective dose equivalent (EDE) to the maximally exposed individual (MEI). The MEI is defined as a member of the public at any publicly accessible location such as a school, recreational area, place of business, or residence. Conservatively, this includes all nonSNL workers, including SNL contractors, members of the military and their dependents, and other non-SNL personnel working or living on $\mathrm{KAFB}$ or near the KAFB perimeter.

The dose calculation identifies the exact location where emissions from all facilities at SNL/NM contribute the highest EDE. CAP88 conservatively assumes that the MEI abides at the receptor location 24 hours a day to receive the maximum potential dose. 


\subsubsection{NESHAP Dose Assessment Input}

\section{Emission Sources}

In 1997, a programmatic review of the SNL/NM NESHAP program found the program to be in excess of the requirements of 40 CFR 61, Subpart H. Monitoring is required of radionuclide sources that have a potential EDE to the MEI of greater than $0.1 \mathrm{mrem} / \mathrm{yr}$, however, there are no facilities at SNL/NM that require stack monitoring according to the regulation. Still, several facilities report emissions based on either periodic stack monitoring or calculations based on measured parameters. As earlier discussed, this practice, while not required by regulation, is performed as part of SNL/NM's Best Management Practices.

As shown in table 5-8, six facilities were used in CAP88 to calculate the EDE to the MEI. Two of these facilities, the HCF and Z-Facility, which are monitored as part of SNL/NM's Best Management Practice, reported zero NESHAP emissions in 1997 and had no contribution to the dose calculated. In some instances, certain radionuclides have such short half lives (for example, 10 minutes for nitrogen-13 and 2 minutes for oxygen-15) that decay during transport, significantly reduces the dose contribution at most receptor locations.

As previously noted, sources with a potential EDE to the MEI of less than $0.1 \mathrm{mrem} / \mathrm{yr}$ do not require monitoring systems and are not required to be used in the calculation of the EDE to the MEI for the purpose of demonstrating compliance with 40 CFR 61, Subpart $H$.

\section{Demographic Data}

Demographic data include population, beef cattle, dairy cattle, and the utilized food crop area fraction for the $80-\mathrm{km}$ radius study area. There are 80 CAP88 analysis zones (16 wind direction sectors subtended by five concentric equally spaced rings out to a distance of $80 \mathrm{~km}$ ). The densities for population, cattle, and food crops were calculated as the quotient of the most recent county data and the county land area.
For the 1997 NESHAP calculations, the estimated 1994-1995 State of New Mexico urban and county population data was obtained from the U.S. Geological Survey (USGS) (DOI 1998) and U.S. Census Bureau data (DOC 1998). The beef and dairy cattle density, and the food crop area fraction were calculated using the 1995 agricultural statistics supplied by the New Mexico Department of Agriculture (NMDOA 1998).

$\begin{array}{ll}15,790 & \text { Dairy cattle } \\ 32,696 & \text { Beef cattle } \\ 87.7 & \text { Food crops (sq mi) } \\ 695,406 & \text { Population (within 80-km radius) }\end{array}$

Public Receptors

Various receptor locations have been evaluated (in the vicinity of SNL/NM) as suspected locations of maximum exposure to a member of the public. Offsite receptor locations are located within the Isleta Indian Reservation, the Four Hills subdivision north of the base, the Manzanita Mountains, and areas near the airport west of the base. A total of 28 receptor locations were evaluated in 1997. The offsite and onsite receptors are listed in tables 5-9 and $5-10$, respectively.

\section{Meteorology}

Data from four meteorological CAN towers in the proximity of NESHAP emission sources were used in 1997 (towers CW1, A36, A21, and MW1). Data from each tower consisted of approximately 35,000 hourly observations of wind direction, wind speed, and stability class (inferred from wind and solar insulation data). The data are compiled into a normalized distribution from which all wind and stability frequency-of-occurrence data were derived. The meteorological data are input to a database to create Stability Array (STAR) data files, which are incorporated into the CAP88 computer code for the dose assessment. 


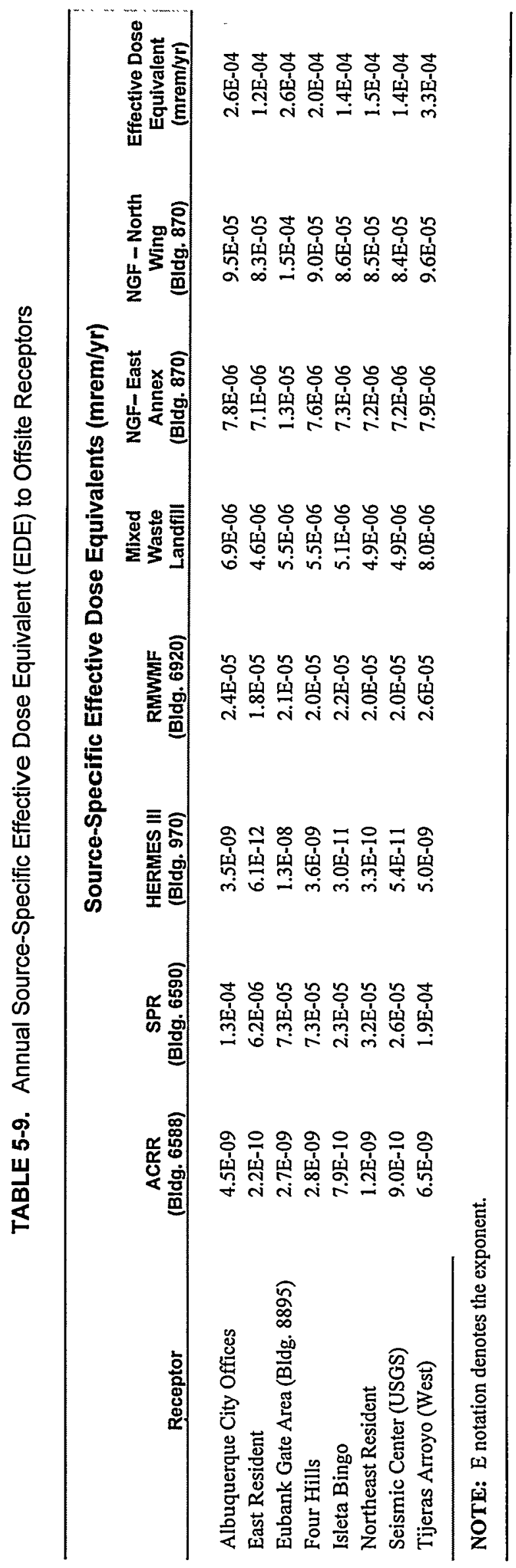




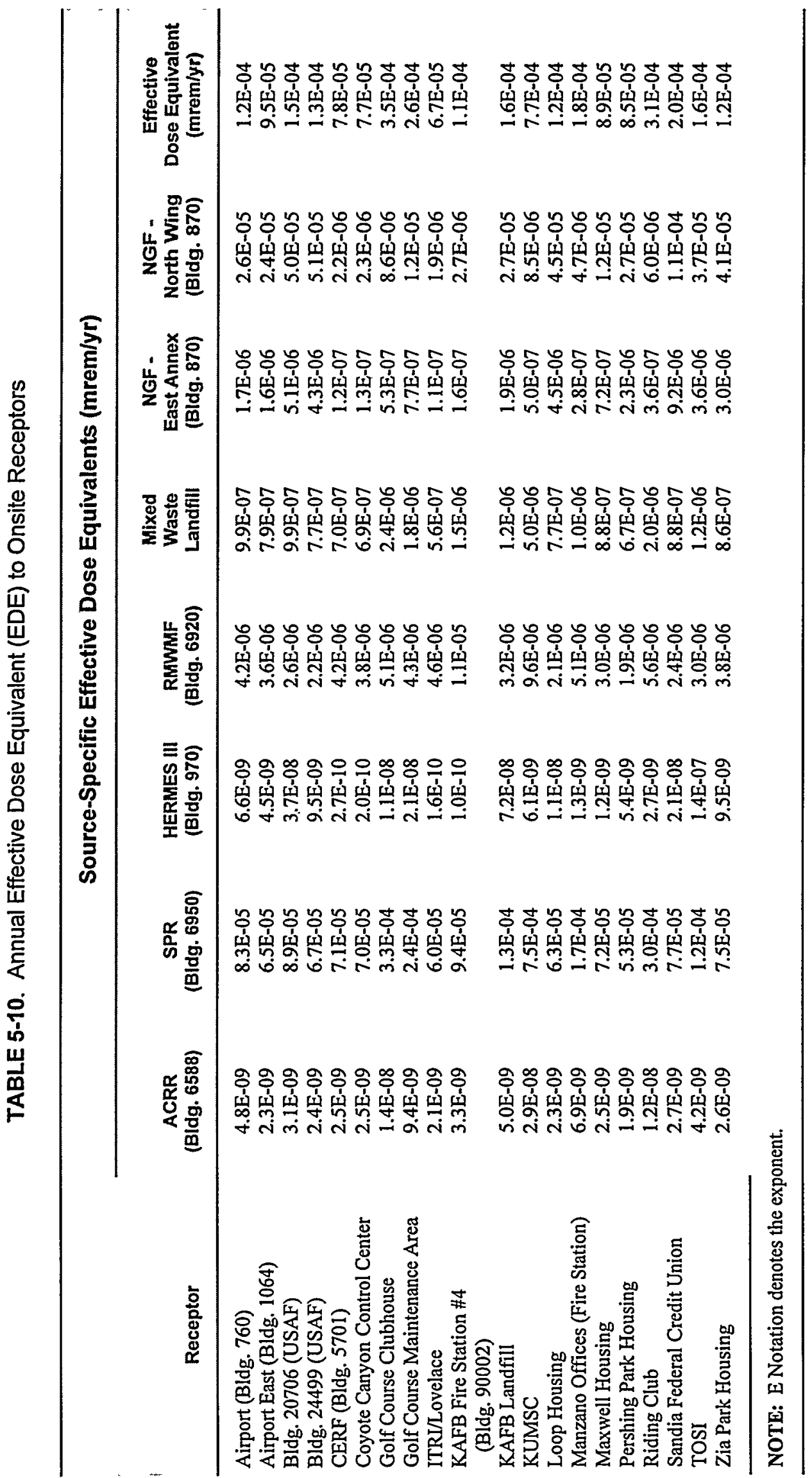




\subsubsection{Dose Assessment Results}

\section{Radiological Dose Modeling}

The CAP88 computer code is an EPA-approved modeling system consisting of a set of computer programs, databases, and associated utilities (EPA 1995). The model calculates exposure that can occur through inhalation, ingestion, air emersion, and surface ground-shine pathways.

CAP88 produces a gaussian plume equation that is used to estimate both horizontal and vertical air dispersion. Each calculation can assess up to 36 radionuclides released from one to six stacks. Radionuclide specific parameters include dose conversion factors, decay constants, and dry deposition velocity. The site-specific data used in the model includes meteorological data; beef, dairy, and human populations; radiological inventories from source facilities; facility release parameters; and public receptor locations.

Dose assessment results are summarized in table 5-11 and discussed below.

\section{MEI Dose}

There were a total of 15 NESHAP sources at SNL/NM in 1997. Of these, parameters from eight facilities were used in the CAP88 code to model the cumulative EDE to the MEI. Two of these facilities produced zero emissions in 1997.

The EDE to the MEI was $7.7 \times 10^{-4} \mathrm{mrem} / \mathrm{yr}$ (0.00077 mrem/year) (7.7 x 10-6 mSv/yr), which is well below the EPA maximum limit of $10 \mathrm{mrem} / \mathrm{yr}(0.1 \mathrm{mSv} / \mathrm{yr})$. The receptor location was again located onsite at the Kirtland Underground Munitions Storage Complex (KUMSC), northwest of the Sandia Pulsed Reactor (SPR) in TA-V. This dose results primarily from exposure to argon- 41 released from the SPR.

Individual EDE doses to offsite and onsite SNL/NM receptors are presented in tables 5-9 and $5-10$, respectively. The offsite MEI was calculated to be $3.3 \times 10^{-4}(0.00033 \mathrm{mrem} / \mathrm{yr})$ (3.3.x $10^{-6} \mathrm{mSv} / \mathrm{yr}$ ) and was located approximately $1,000 \mathrm{~m}$ due south from the point where the Tijeras Arroyo exits KAFB's western boundary.

\section{Population Doses}

A population dose resulting from the exposure produced from all SNL/NM radiological emissions was calculated for both KAFB and the regional area. Population dose is attained by multiplying a representative individual dose within a population with the total population. SNL/NM calculates a population dose for both the KAFB housing areas and the general Albuquerque area population within a 80kilometer (50-mile) radius. Population dose is not required by NESHAP regulations; however, it provides a useful numerical comparison of the public dose from year to year.

The Albuquerque regional population dose in 1997 was attained using a single, common grid analysis for all SNL/NM sources. Because the analysis area is large, the relatively small distances between radionuclide sources have a minimal impact on the resulting population dose. The population dose was calculated by multiplying 695,406 residents by doses per sector to attain 0.023 person-rem/yr $(0.00023$ personSv/yr). This dose resulted primarily from exposure to argon- 41 and tritium.

A population dose for KAFB residents was calculated based on four main housing areas. The total population dose for KAFB was obtained by summing the four areas assuming a total residential population of 5,673. This resulted in an estimated population dose of 0.00063 person-rem/yr (0.0000063 person-Sv). Again, the dose resulted primarily from exposure to argon-41 and tritium. 
TABLE 5-11. Calculated Dose Assessment Results for Onsite and Offsite Receptors and for Collective Populations

\begin{tabular}{|c|c|c|c|c|}
\hline Dose to Receptor & Location & 1997 Calculated Dose & $\begin{array}{l}\text { NESHAP } \\
\text { Standard }\end{array}$ & $\begin{array}{l}\text { Natural } \\
\text { Background }\end{array}$ \\
\hline $\begin{array}{l}\text { Onsite Receptor } \\
\text { EDE to the MEI }\end{array}$ & KUMSC & $\begin{array}{l}0.00077 \mathrm{mrem} / \mathrm{yr} \\
(0.0000077 \mathrm{mSv} / \mathrm{yr})\end{array}$ & $\begin{array}{l}10 \mathrm{mrem} / \mathrm{yr} \\
(0.1 \mathrm{mSv} / \mathrm{yr})\end{array}$ & $95 \mathrm{mrem} / \mathrm{yr}^{1}$ \\
\hline $\begin{array}{l}\text { Offsite Receptor } \\
\text { EDE to the MEI }\end{array}$ & $\begin{array}{l}\text { Tijeras Arroyo } \\
\text { West of KAFB }\end{array}$ & $\begin{array}{l}0.00033 \mathrm{mrem} / \mathrm{yr} \\
(0.0000033 \mathrm{mSv} / \mathrm{yr})\end{array}$ & $\begin{array}{l}10 \mathrm{mrem} / \mathrm{yr} \\
(0.1 \mathrm{mSv} / \mathrm{yr})\end{array}$ & $95 \mathrm{mrem} / \mathrm{yr}^{1}$ \\
\hline $\begin{array}{l}\text { Collective KAFB } \\
\text { Population }^{3}\end{array}$ & KAFB housing & $\begin{array}{l}0.00063 \text { person-rem } / y r \\
(0.0000063 \text { person-Sv/yr) }\end{array}$ & $\begin{array}{l}\text { No standard } \\
\text { available }\end{array}$ & - \\
\hline $\begin{array}{l}\text { Collective Regional } \\
\text { Population }^{2}\end{array}$ & $\begin{array}{l}\text { Residents within an } \\
80-\mathrm{km} \text { radius }\end{array}$ & $\begin{array}{l}0.023 \text { person-rem/yr } \\
(0.00023 \text { person-Sv/yr) }\end{array}$ & $\begin{array}{l}\text { No standard } \\
\text { available }\end{array}$ & $\overline{--}$ \\
\hline
\end{tabular}

NOTE: $\mathrm{EDE}=$ effective dose equivalent

$\mathrm{MEI}=$ maximally exposed individual

KUMSC $=$ Kirtland Underground Munitions Storage Complex

NESHAP = National Emissions Standards for Hazardous Air Pollutants

$\mathrm{mSv}=$ milli-sievert

person-Sv = person seviert

$195 \mathrm{mrem} / \mathrm{yr}$ is based on average local community values obtained from the thermoluminescent dosimeter (TLD)

network maintained by SNL/NM. (The nationwide average is $360 \mathrm{mrem} / \mathrm{yr}$.)

2 Based on a population of 695,406 people estimated to be living within an 50-mile (80-km radius).

3 Based on a population of 5,673 people estimated to be living in permanent on-base housing.

\section{AIR QUALITY \\ REQUIREMENTS AND COMPLIANCE STRATEGIES}

This section discusses all applicable air quality requirements as they apply to the SNL/NM site and include the requirements discussed under the Ambient Air Program (Section 5.2) and the NESHAP Program (Section 5.3).

Air quality for SNL/NM is governed by regulations promulgated by both the Albuquerque/Bernalillo County Air Quality Control Board (ABC/AQCB) and the federal government. Radionuclide emissions are administered directly by the EPA under NESHAP-40 CFR 61, Subpart H. Drivers for air quality compliance also include DOE Order 5400.1, General Environmental Protection Program (Chapter IV, Part 5) (DOE 1990a). A complete listing of air quality regulations applicable to SNL/NM is given in table 5-12.

\subsubsection{New Program Directions Under CAAA Title V}

Amendments to the Clean Air Act in 1990 (CAAA) contained provisions under Title $\mathrm{V}$ requiring all existing "major air emission sources" to obtain an operating permit. A major source is defined as the combined emissions from any facility with the potential to emit 100 tons per year (tpy) or greater of any criteria pollutant, 10 tpy of any hazardous air pollutant (HAP), or 25 tpy of any combination of HAPs. SNL/NM is considered a major source based on its potential to emit nitrogen oxides $\left(\mathrm{NO}_{\mathrm{x}}\right)$ and carbon monoxide (CO). The intent of Title $\mathrm{V}$ is not to add new requirements, but to pull together existing requirements under one regulation. DOE will eventually submit just one annual report to $\mathrm{COA}$ regarding air quality compliance.

DOE submitted SNL/NM's CAAA Title V Operating Permit application on March 1, 1996, which included the Steam Plant (a major source in itself) and all other combined sources such as generators and minor units. DOE's Title $\mathrm{V}$ 
TABLE 5-12. Air Regulations Applicable to SNL/NM

This table shows the relationship between state and federal regulations and the underlying Clean Air Act.

\begin{tabular}{|c|c|c|c|c|}
\hline $\begin{array}{l}\text { CAA } \\
\text { Title }\end{array}$ & $\begin{array}{l}\text { Federal } \\
\text { Regulation }\end{array}$ & $\begin{array}{l}\text { Local } \\
\text { Regulation }\end{array}$ & Subject & $\begin{array}{l}\text { Applicable Activities } \\
\text { and Facilities }\end{array}$ \\
\hline \multirow[t]{15}{*}{ Title I } & $\begin{array}{l}40 \text { CFR } 93 \mathrm{~B} \\
40 \text { CFR } 51 \mathrm{~W}\end{array}$ & $\begin{array}{l}20 \text { NMAC } 11.03 \\
20 \text { NMAC } 11.04\end{array}$ & $\begin{array}{l}\text { Conformity (State and Federal } \\
\text { Plans) }\end{array}$ & General \\
\hline & $\begin{array}{l}40 \text { CFR } 58 \\
\text { (Subpart C-Air } \\
\text { Programs) }\end{array}$ & & $\begin{array}{l}\text { Ambient Air Quality } \\
\text { Surveillance }\end{array}$ & $\begin{array}{l}\text { Air Quality Surveillance } \\
\text { Program - SLAMS }\end{array}$ \\
\hline & 40 CFR 50 & 20 NMAC 11.01 & $\begin{array}{l}\text { National Primary and } \\
\text { Secondary Ambient Air Quality } \\
\text { Standards (NAAQS) }\end{array}$ & $\begin{array}{l}\text { Establishes ambient air } \\
\text { quality standards for criteria } \\
\text { pollutants }\end{array}$ \\
\hline & 40 CFR 52 & 20 NMAC 11.02 & Permit Fees & $\begin{array}{l}\text { Asbestos, inventories, } \\
\text { permits, reviews, } \\
\text { registrations }\end{array}$ \\
\hline & 40 CFR 52 & 20 NMAC 11.05 & Visible Air Contaminants & $\begin{array}{l}\text { - SMERF(exempt) } \\
\text { - SWISH (exempt) } \\
\end{array}$ \\
\hline & 40 CFR 52 & 20 NMAC 11.06 & Emergency Action Plan & If formulated by AEHD \\
\hline & 40 CFR 52 & 20 NMAC 11.07 & Variance Procedure & If variance is sought \\
\hline & 40 CFR 52 & 20 NMAC 11.20 & $\begin{array}{l}\text { Airborne Particulate Matter } \\
\text { (PM) }\end{array}$ & $\begin{array}{l}\text { Surface disturbing over } 3 / 4 \\
\text { acre (e.g., general } \\
\text { construction or demolition } \\
\text { and sand blasting) }\end{array}$ \\
\hline & 40 CFR 52 & 20 NMAC 11.21 & Open Burning & $\begin{array}{l}\text { - Open burns conducted at } \\
\text { the Burn Site and Cable } \\
\text { Facility } \\
\text { - Explosive detonations }\end{array}$ \\
\hline & 40 CFR 51-52 & 20 NMAC 11.40 & Source Registration & $\begin{array}{l}\text { Facilities with emissions }>1 \\
\text { tpy of HAP or criteria } \\
\text { pollutants } \\
\text { - SMERF } \\
\text { - Neutron Generator Facility }\end{array}$ \\
\hline & 40 CFR 51-52 & 20 NMAC 11.41 & Authority-to-Construct & $\begin{array}{l}\text { Potential operating } \\
\text { conditions for facilities with } \\
\text { emissions }>25 \text { tpy or }>10 \\
\mathrm{lb} / \mathrm{hr} \text { or }>5 \text { tpy of } \mathrm{Pb} \text { or } \\
\text { NESHAP-listed pollutant } \\
\text { - Hammermill } \\
\text { - } 4 \text { stand-by generators }\end{array}$ \\
\hline & 40 CFR 51.100 & 20 NMAC 11.43 & Stack Height Requirements & Good engineering practice \\
\hline & 40 CFR 51 & 20 NMAC 11.44 & Emissions Trading & Applicable if credit taken \\
\hline & 40 CFR 51-52 & $20 \mathrm{NMAC} 11.60$ & $\begin{array}{l}\text { Permitting in Nonattainment } \\
\text { Areas }\end{array}$ & Applicable if $>100$ tpy $\mathrm{CO}$ \\
\hline & 40 CFR 52 & 20 NMAC 11.61 & $\begin{array}{l}\text { Prevention of Significant } \\
\text { Deterioration (PSD) }\end{array}$ & Applicable if $>250$ tpy \\
\hline
\end{tabular}

NOTE: $\mathrm{AEHD}=$ Albuquerque Environmental Health Department

HAP $=$ Hazardous Air Pollutant

N/A = not applicable

$\mathrm{PM}=$ particulate matter

SLAMS = Standards for state and local air monitoring stations

SMERF $=$ SMoke Emission Reduction Facility

SWISH $=$ Small WInd SHielded Facility 
TABLE 5-12. Air Regulations Applicable to SNL/NM (concluded)

This table shows the relationship between state and federal regulations and the underlying Clean Air Act.

\begin{tabular}{|c|c|c|c|c|}
\hline $\begin{array}{l}\text { CAA } \\
\text { Title }\end{array}$ & $\begin{array}{l}\text { Federal } \\
\text { Regulation }\end{array}$ & Local Regulation & Subject & $\begin{array}{l}\text { Applicable Activities } \\
\text { and Facilities }\end{array}$ \\
\hline \multirow[t]{7}{*}{ Title I } & $\begin{array}{l}40 \text { CFR } 60 \\
40 \text { CFR } 63\end{array}$ & $20 \mathrm{NMAC} 11.65$ & $\begin{array}{l}\text { Volatile Organic Compounds } \\
\text { (VOC) }\end{array}$ & $\begin{array}{l}\text { - Fuel use (N/A) } \\
\text { - Remediation of solvent } \\
\text { contaminated soil } \\
\text { - Groundwater treatment }\end{array}$ \\
\hline & 40 CFR 60 & 20 NMAC 11.66 & Process Equipment & - Hammermill for PM \\
\hline & 40 CFR 60 & 20 NMAC 11.22 & Wood Burning & N/A \\
\hline & 40 CFR 60 & 20 NMAC 11.63 & $\begin{array}{l}\text { New Source Performance } \\
\text { Standards (NSPS) }\end{array}$ & $\begin{array}{l}\text { Prescribes operating } \\
\text { conditions for new or } \\
\text { modified NSPS facilities }\end{array}$ \\
\hline & 40 CFR 60 & 20 NMAC 11.67 & $\begin{array}{l}\text { Equipment, Emissions and } \\
\text { Limitations } \\
\text { (regulates } \mathrm{NO}_{2}, \mathrm{PM} \text {, and } \mathrm{SO}_{2} \\
\text { from gas-burning and oil- } \\
\text { burning equipment) }\end{array}$ & $\begin{array}{l}\text { N/A } \\
\text { (the five natural gas-burning } \\
\text { boilers at the steam plant } \\
\text { produce less than the rated } \\
\text { heat capacity threshold of } \\
250 \mathrm{Mbtu} / \mathrm{hr} \text { ) }\end{array}$ \\
\hline & 40 CFR 60 & 20 NMAC 11.68 & Incinerators & N/A \\
\hline & 40 CFR 60 & 20 NMAC 11.69 & Pathological Waste Destructors & N/A \\
\hline \multirow[t]{4}{*}{ Title II } & 40 CFR $85-86$ & 20 NMAC 11.100 & Motor Vehicle Inspection & Emission Testing \\
\hline & & 20 NMAC 11.101 & $\begin{array}{l}\text { - Decentralized and Centralized } \\
\text { (respectively) }\end{array}$ & \multirow{3}{*}{$\begin{array}{l}\text { SNL's fleet of over } 800 \\
\text { vehicles, inspection and } \\
\text { emissions testing }\end{array}$} \\
\hline & 40 CFR 80 & 20 NMAC 11.102 & Oxygenated Fuels & \\
\hline & & 20 NMAC 11.103 & $\begin{array}{l}\text { Motor Vehicle Visible } \\
\text { Emissions }\end{array}$ & \\
\hline Title III & $\begin{array}{l}40 \text { CFR } 61 \\
40 \text { CFR } 63\end{array}$ & $\begin{array}{l}20 \text { NMAC } 11.64 \\
\text { nonradionuclides }\end{array}$ & $\begin{array}{l}\text { NESHAP } \\
\text { Subpart C-Beryllium (Be) } \\
\text { Subpart H }- \text { Radionuclides other } \\
\text { than Radon (EPA regulates } \\
\text { directly) } \\
\text { Subpart M-Asbestos } \\
\end{array}$ & $\begin{array}{l}\text { A hazardous chemical } \\
\text { purchase inventory for CY97 } \\
\text { was conducted }\end{array}$ \\
\hline Title IV & 40 CFR 72-78 & 20 NMAC 11.62 & Acid Rain & N/A \\
\hline Title V & 40 CFR 70-71 & 20 NMAC 11.42 & $\begin{array}{l}\text { Operating Permit } \\
\text { (Application under Review) }\end{array}$ & $\begin{array}{l}\text { For existing major sources } \\
\text { ( }>100 \text { tpy): } \\
\text { - Steam Plant } \\
\text { - Generators }\end{array}$ \\
\hline Title VI & 40 CFR 82 & 20 NMAC 11.23 & Ozone Protection & $\begin{array}{l}\text { Limiting the use of Class I } \\
\text { and Class II ODSs } \\
\text { - Auto air conditioners } \\
\text { - Refrigerators } \\
\text { - Chillers } \\
\end{array}$ \\
\hline \multirow[t]{2}{*}{ Title VII } & 40 CFR 64 & 20 NMAC 11.90 & $\begin{array}{l}\text { Administration, Enforcement, } \\
\text { Inspection }\end{array}$ & $\begin{array}{l}\text { Breakdown, abnormal } \\
\text { operating condition/ } \\
\text { scheduled maintenance }\end{array}$ \\
\hline & & 20 NMAC 11.100 & $\begin{array}{l}\text { Motor Vehicle Inspection - } \\
\text { Decentralized }\end{array}$ & Emission testing \\
\hline
\end{tabular}

NOTE: $\mathrm{N} / \mathrm{A}=$ not applicable

ODS $=$ ozone depleting substances

$\mathrm{PM}=$ particulate matter 
permit application was deemed complete on May 1, 1996. It is expected that the permit will be drafted by March 13, 1998.

The proposed Title V Orating Permit will integrate all CAAA requirements into one sitewide permit which may be inclusive of several facilities in the general area, including SNL/NM and DOE's facilities on KAFB.

As discussed in section 2.3, the Title V Operating Permit will change the current emission fee system. Currently, SNL/NM is assessed an annual per-ton fee based on its maximum potential-to-emit of air pollutants. For example, the steam plant is assessed on the assumption that it will be operating at full capacity year-round. Under Title V, SNL/NM may be allowed to designate a self-imposed cap on fuel usage and thus plan a more realistic estimate of the actual fuel used. A fee will be paid based on this self-imposed fuel cap whether the usage is met or not. The permit is also expected to limit the need to acquire individual source permits through pre-approval.

\subsubsection{New Air Compliance Activities in 1997}

\section{New Air Permit for Classified Waste Landfill Remediation}

Site preparation at the Classified Waste Landfill in TA-II began in late 1997. SNL/NM applied for an Authority-to-Construct Permit (\# 560) for the remediation, which is scheduled to begin in 1998. Monitoring of fugitive emissions during the project will also be conducted.

\subsubsection{Criteria Pollutants}

The EPA must describe the characteristics and potential health effects of "criteria pollutants" known to be hazardous to human health (Section 5.2.1). For these criteria pollutants, the EPA is empowered by the CAA to:
- Set ambient air quality standards, including motor vehicle emissions;

- Require states to submit plans for protection and improvement of air quality;

- Institute a program to prevent the nation's air from deteriorating below standards; and

- Establish a program for controlling hazardous air pollutants (HAPs).

Standards for criteria pollutants are implemented by 40 CFR 50 and 20 NMAC 11.01. Compliance is ensured through ambient monitoring conducted under the Ambient Air Monitoring Program (Section 5.2).

\section{New EPA Standards}

As discussed in section 5.2.1, the EPA reviewed and made changes to two NAAQSs in 1997; stricter ambient air standards were adopted for particulate matter and ozone (PM and $\mathrm{O}_{3}$ ). Currently, all ambient air monitoring of criteria pollutants by SNL/NM is voluntary. $\mathrm{PM}_{10}$ (particulate matter less than 10 microns in diameter) is the current criteria pollutant designation-the standard now includes $\mathrm{PM}_{2.5}$. The COA began gathering $\mathrm{PM}_{2.5}$ data in 1997 in anticipation of the new requirement. SNL/NM plans to incorporate $\mathrm{PM}_{2.5}$ monitoring into its ambient air monitoring capabilities in 1998 . The COA has asked SNL/NM to assist in a study to determine if local conditions contribute to $\mathrm{O}_{3}$ production given the ratio of either $\mathrm{NO}_{\mathbf{X}}$ or VOCs in the air.

\section{Criteria Pollutant Sources}

The significant sources of criteria pollutants at SNL/NM are listed below. The Steam Plant is currently the only "major source" (>100 tpy).

- Steam Plant - The Steam Plant is used primarily to produce steam heat for buildings in TA-I and KAFB East. Because this is a "grandfathered" source, no permit 
has previously been required. The Steam Plant falls beneath the minimum limits for compliance with New Mexico regulation 20 NMAC 11.67, "Equipment Emissions, Limitations." However, the plant is now subject to the requirements of Title V, because the emissions are greater than 100 tpy. A Title V Operating Permit is expected to be issued in 1998. SNL/NM is currently meeting Title $\mathrm{V}$ compliance by paying the annual permit fee. A prototyping initiative for future Title $\mathrm{V}$ compliance has been started at the Steam Plant by tracking fuel throughput and implementing selfimposed fuel caps. Because fuel throughput will likely be used to estimate emissions, criteria pollutant monitoring and stack sampling may not be required.

During 1997, all five boilers at the plant were operational and consumed a total of 761 million standard cubic feet $\left(\mathrm{ft}^{3}\right)$ of natural gas. These boilers can also be run on diesel oil. During 1997, they consumed 92,000 gal of diesel oil.

In 1997, a Steam Plant Optimization Study was initiated to reduce the facility's emissions. The boilers were tuned to optimum running conditions to attain the lowest fuel use per hour.

- Emergency generator plant - SNL/NM operates four standby diesel generators located in TA-1, each with a 600-kilowatt $(\mathrm{kW})$ capacity. The generators in Bldg. 862 are currently permitted (\#150 and \#402). For the purpose of Title $\mathrm{V}$ compliance, SNL/NM has assumed a maximum usage of $500 \mathrm{hr} / \mathrm{yr}$ for each generator. All generator use is based on an annual fuel throughput cap. The generators are exercised monthly and electrically tested quarterly. In anticipation of Title $\mathrm{V}$ fuel caps, SNL/NM has proposed a $500 \mathrm{hr} / \mathrm{yr}$ per generator usage, which will include these and all other generators located onsite. In 1997, the four generators used 4,100 gal of diesel oil.
- Vehicles - SNL owns about 11 vehicles that must meet local emissions testing. SNL/NM's other 800 vehicles are managed by the General Services Administration (GSA). 20 NMAC 11.100 states that persons who are responsible for such government fleet vehicles or motor pools shall periodically, but not less than annually, update the vehicle inventory and forward the resulting inspection plan with inventory to the program manager.

- Open Burns - The open-burning regulation covers activities such as:

- Disposing explosives by burning to avoid the hazards of transport or handling;

- Aboveground detonating of explosives over $20 \mathrm{lb}$;

- Burning liquid fuel of 2,000 gal or more for a single-event research and development activity; and

- Igniting rocket motors containing more than $4,000 \mathrm{lb}$ of fuel.

In addition, the regulation differentiates the permit basis into two categories: multiple-event and single-event. The single-event permit was designed to regulate activities having significant impact. Open-burn permits were obtained during 1997 from the COA for each scheduled regulated burn or test according to 20 NMAC 11.21.

\section{Air Quality Awards}

In December 1997, SNL/NM received a Joint Industry and Government Pollution Prevention Air Quality Award. The New Mexico Facility Managers Network in conjunction with the COA issued the 1997 Pollution Prevention Honorable Mention to SNL for demonstrating exemplary management commitment to the environment. 


\subsubsection{Pollution Prevention in Permitting Pilot (P4) Project}

The City of Albuquerque nominated DOE to participate in EPA's Pollution Prevention in Permitting Pilot (P4) Project. The project commenced in January 1997 as a new initiative to incorporate pollution prevention into EPA's permitting activities. The primary goal of the P4 Project was to identify opportunities and barriers to using flexible regulatory and non-regulatory activities. DOE was nominated because the Albuquerque Environmental Health Department (AEHD) has expressed confidence in both the current working relationship with $\mathrm{DOE}$, and DOE's technical capability for implementing a project of this importance. SNL/NM's role in the project was to be the lead as the major source for $\mathrm{NO}_{\mathbf{X}}$ and $\mathrm{CO}$. The Steam Plant received a $\mathrm{P} 4$ award for reduction of facility emissions. However, in March 1997, AEHD and DOE mutually agreed to discontinue the project, because it became clear that the DOE's permitting needs could be addressed and resolved more expediently within the traditional operating permit process.

\section{Air Quality Compliance Documentation} Documents specific to the NESHAP Program, the Ambient Air Surveillance Program, the Meteorological Monitoring Program, and the Air Quality Compliance Program are shown in table 5-13.

TABLE 5-13. Important Documents for All Air Quality Programs at SNL/NM

\begin{tabular}{|l|l|}
\hline Program Document & Reference \\
\hline NESHAP PROGRAM & \\
\hline $\begin{array}{l}\text { 1. NESHAP Annual Report for 1997 (EPA Summary), and } \\
\text { 2. Radiological Dose Calculation and Supplementation Dose } \\
\text { Assessment Data }\end{array}$ & SNL 1998b \\
\hline Radiological NESHAP Quality Assurance Project Plan (QAPjP) & SNL 1997e \\
\hline AQC PROGRAM & \\
\hline Title V Permit Application, \# 515 (7-volume document) & no reference \\
\hline $\begin{array}{l}\text { Corporate Ozone Depleting Substances (ODS) Management Program } \\
\text { (PG) }\end{array}$ & SNL 1997f \\
\hline Ozone Depleting Substances (ODS) Management Plan & SNL 1997a \\
\hline $\begin{array}{l}\text { Air Quality Compliance Quality Assurance Project Plan (QAPjP) for } \\
\text { Air Quality Compliance }\end{array}$ & SNL 1996j \\
\hline Air Quality (PG) & SNL 1997g \\
\hline $\begin{array}{l}\text { Supporting Documentation for the Hazardous Chemical Purchase } \\
\text { Inventory 1997 Reporting Year* }\end{array}$ & SNL 1998a \\
\hline CAN PROGRAM & \\
\hline Inspection and Maintenance Plan for Guyed Structures (Met towers) & SNL 1997h \\
\hline $\begin{array}{l}\text { Quality Assurance Project Plan (QAPjP) for Meteorological and } \\
\text { Ambient Air Monitoring Program }\end{array}$ & SNL 1997i \\
\hline
\end{tabular}

NOTE: * No Toxic Release Inventory (TRI) report was required for CY97. This report was published to document the calculations showing SNL/NM was under the threshold reporting values.

PG denotes a "Program Document" which is a specific type of ES\&H document. 


\section{Wastewater, SuRface Discharge, AND Storm Water Programs}

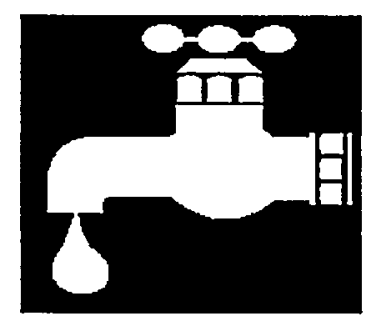

$\mathrm{E}$ ffluent monitoring is the collection of samples or direct measurement taken from liquid or gaseous waste stream processes for the purpose of quantifying contaminants and determining regulatory compliance. Effluent monitoring in this chapter is confined to water monitoring activities that include sanitary and industrial discharges, surface discharges, and storm water runoff.

All water quality monitoring is conducted by SNL/NM's Environmental and Emergency Management Department. SNL/NM complies with the water quality regulations established by local, state, and federal agencies. U.S. Environmental Protection Agency (EPA) standards are implemented at the state and local level by the New Mexico Environment Department (NMED) and the City of Albuquerque (COA). The state and the COA establish water quality standards at least as strict as the federal standards. SNL/NM also adheres to the wastewater guidelines contained in DOE Orders 5400.1 and 5400.5 (DOE 1990a, DOE 1993a).

\section{1 wastewater DISCHARGE PROGRAM}

Wastewater discharged to the sewer system at SNL/NM is divided into two categories: sanitary discharges and industrial discharges. Sanitary waste streams include wastewater from lavatories, food service establishments, showers, and other domestic-type activities. Industrial discharges are produced from general laboratory research operations including electroplating, metal finishing, microelectronic development, and photographic processes.

Sandia's sewer system connects to the COA's sanitary sewer system, also referred herein as a publicly-owned treatment works (POTW). Wastewater is treated at the COA's water reclamation plant near the point where Tijeras Arroyo meets the Rio Grande. All treated water must meet EPA discharge limits as defined in the National Pollutant Elimination Discharge System (NPDES) before the city can discharge to the Rio Grande.

The COA regulates SNL/NM's discharges to the POTW through permits that define the physical and chemical concentrations allowed. SNL/NM complies with allowable limits, which are enforced at the boundaries of SNL/NM's Technical Areas. All wastewater generated at SNL/NM flows through one of four general monitoring stations before leaving the site.

The POTW's biological treatment processes are sensitive to an excess of certain chemicals. Industrial wastes (including commonly used laboratory chemicals) can interfere with sewage treatment operations. Heavy metals, specifically cadmium, chromium, copper, lead, mercury, nickel, silver, and zinc can be particularly harmful to the biological balance. Toxic organic compounds (including solvents and pesticides) and cyanide are also closely regulated. Another pollutant source is from building cooling units, which concentrate dissolved salts in the water reservoirs. 
SNL/NM closely monitors its liquid effluent discharges and strives to minimize toxic pollutants through cognizant pollution prevention and waste minimization. Flow and $\mathrm{pH}$ are monitored 24 hours per day. Monthly samples are taken to determine compliance with specific regulatory parameters. SNL/NM practices pollution prevention and waste minimization through good management and engineering practices. For example, chemical substitutions and equipment modifications are made where feasible to reduce hazardous material use at the source.

Wastewater is also discharged at three active septic systems in areas where sewer line hookup is not available. These septic tanks are periodically sampled to check that the contents meet all regulatory criteria before being pumped and discharged to the POTW.

\subsubsection{Wastewater Monitoring Stations}

Figure 6-1 shows SNL/NM's six onsite wastewater monitoring stations. Station parameters are listed in table 6-1. Two stations are upstream of the general outfalls and are defined under categorical pretreatment operations. The EPA has established categorical pretreatment standards for specified classes of industrial discharges. Station WW007 monitors the wastewater discharged from the acid waste neutralization system at the Microelectronics Development Laboratory (MDL) in TA-I. Station WW009 monitors wastewater generated from the operations in the Advanced Manufacturing Process Laboratory (AMPL) also in TA-I. However, in late 1997, WW009 became a zero discharge operation. The total combined wastewater discharges to the POTW are approximately 800,000 gal per day.

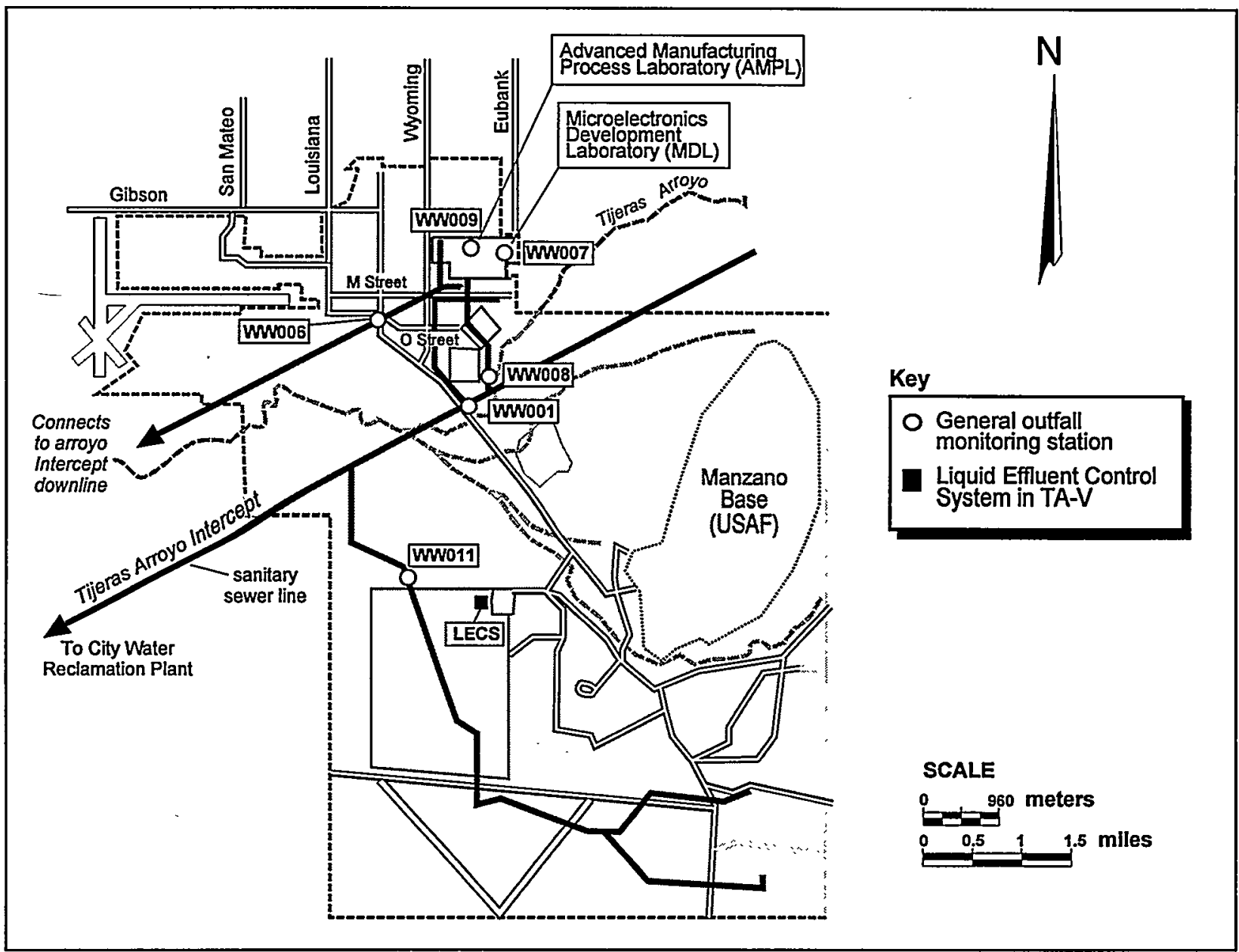


TABLE 6-1. SNL/NM Wastewater Discharge Permits and Station Characteristics

\begin{tabular}{|c|c|c|}
\hline Permit & Waste Stream Process & Flume Size \\
\hline WW001 & General & 3 inch Parshall \\
\hline WW006 & General & 6 inch Parshall \\
\hline WW007 & MDL & $45^{\circ}$ v-notch Weir \\
\hline WW009 & AMPL & 2 inch Parshall \\
\hline WW008 & General & 6 inch Parshall \\
\hline WW011 & General & 6 inch Parshall \\
\hline
\end{tabular}

NOTE: MDL $=$ Microelectronics Development Laboratory

AMPL $=$ Advanced Manufacturing Process Laboratory

All discharges from the MDL and AMPL flow through General Station WW008

before discharging to the POTW. WW009 is a zero discharge operation.

TABLE 6-2. Primary Regulatory Drivers for the Wastewater Discharge Program

\begin{tabular}{|l|l|}
\hline Regulation & Citation \\
\hline Clean Water Act (CWA) & Title 33, U.S.C. 1251 \\
\hline COA Sewer Use and Wastewater Control Ordinance & Chapter XIII, Article IX Section 8-944.H (1990) \\
\hline NMWQCC Regulations & 20 NMAC 6.2* \\
\hline $\begin{array}{l}\text { U.S. NRC regulations } \\
\text { for radiological levels in wastewater }\end{array}$ & 10 CFR 20 \\
\hline $\begin{array}{l}\text { Radiation Protection of the Public and the } \\
\text { Environment }\end{array}$ & DOE Order 5400.5 \\
\hline
\end{tabular}

NOTE: *Implements the New Mexico Water Quality Act.

$\mathrm{COA}=$ City of Albuquerque

U.S. NRC = United States Nuclear Regulatory Commission

NMWQCC $=$ New Mexico Water Quality Control Commission

\subsubsection{Permitting and Reporting}

The COA Public Works Department, Liquid Waste Division, implements EPA's water quality standards under the authority of the City's "Sewer Use and Wastewater Control Ordinance," Section 8-9-44.H. Primary regulatory drivers for the Wastewater Program are listed in table 6-2.

The COA's reporting requirements are defined under its Industrial Wastewater Pretreatment Program. This program specifies the required quality of discharges that the City will accept at its water reclamation plant. To meet these standards, SNL/NM requires all internal organizations producing continuous process discharges-other than sanitary effluent-to obtain prior approval from the Water Quality Group within the Environmental and Emergency Management Department. This department maintains a discharge program to track process wastewater leaving SNL/NM. The amount, frequency, location, composition, and process associated with the discharge is documented and reviewed by the Water Quality Group. Approval is made if the discharge meets acceptable criteria. Internal permits are issued for approved processes and reviewed annually (or whenever the wastewater processes change). One time releases are evaluated on a case-bycase basis. If pollutants above regulatory levels 
are detected in the waste stream, SNL/NM will conduct an investigation to discover the source of the discharge and implement corrective actions, as needed.

In addition to the sampling performed by SNL/NM, the COA performs quarterly inspections and sampling at SNL/NM's outfall stations. During 1997, COA staff toured SNL facilities to inspect for compliance with the discharge requirements. SNL/NM received three Gold Pretreatment Awards and three Silver Awards from the City of Albuquerque for its adherence to requirements in FY1997. The New Mexico Environment Department (NMED) also took samples in 1997.

\section{Wastewater Control Documents}

Sandia's discharge requirements are defined in Chapter $10 \mathrm{H}$ of the ES\&H Manual, (SNL 1998j). The SNL/NM Sampling and Analysis Plan (SNL 1996k) defines sampling procedures, sampling frequency, analytical methods, and quality control/quality assurance (QC/QA) criteria. Semi-annual wastewater reports were submitted, as required, to the COA by July 31 , 1997, for the first reporting period (January to June) and by January 31, 1998, for the second reporting period (July to December).

\subsubsection{TA-V Radiological Screening}

Several research reactors in $T A-V$ have the potential to produce radiologically-contaminated process wastewater. To ensure that all wastewater from these facilities meets regulatory standards, liquid effluent is separated into two streams: reactor and non-reactor wastewater. All non-reactor sanitary wastewater is discharged directly to the sanitary sewer. Reactor process wastewater, which is defined as effluent originating from any drain located in a building that uses, processes, or stores radioactive material, is diverted to the Liquid Effluent Control System (LECS). The LECS consists of three 5,000-gallon tanks and an ion exchange and filter system. SNL/NM prohibits the disposal of radiological material above regulatory levels into the sanitary sewer system.

All wastewater diverted to the LECS is screened for radiological contaminants before water is allowed to be discharged to the sanitary sewer. Alarms have been installed to alert personnel to the presence of radioactive materials or high water levels. Samples are taken about once a month (depending on how much water is collected) and sent to an EPA-approved laboratory for analysis of gross alpha and gross beta activities, tritium, and gamma spectroscopy. If no significant activity is detected, the water is then released to the sanitary sewer system. However, if radioactivity levels above the limits are detected, the water is held for alternative disposal. Short-lived radioisotopes may be allowed to decay in place until they have reached insignificant levels and can be safely discharged to the sewer system.

Until 1997, no radiological contamination was ever detected by the LECS. On July 15, 1997 , elevated tritium was detected at $2,000 \mathrm{pCi} / 1$ after wastewater from the Annular Core Research Reactor (ACRR) was transferred to the tanks while it was undergoing modification in preparation for the Medical Isotope Production Project (MIPP). The water was not discharged to the sewer.

\subsubsection{Wastewater Sampling}

Wastewater permits issued by the COA detail the requirements of SNL/NM's monitoring program. As previously noted, continuous monitoring of $\mathrm{pH}$ and flow is conducted at all stations, and periodic samples are collected at general stations to determine compliance with discharge limits stated in each permit. Quarterly, SNL/NM and COA sample at selected stations. All samples are taken as 24hour flow proportional composites. Samples are sent for analysis to EPA-approved contract laboratories. Typical wastewater parameters sampled are listed below: 


\begin{tabular}{ll} 
Aluminum & Tritium \\
Arsenic & Gross alpha \& beta \\
Copper & Gamma spectroscopy \\
Chromium & Cyanide \\
Lead & Soluble fluoride \\
Mercury & Chemical oxygen demand (COD) \\
Nickel & Phenolic compounds \\
Selenium & Oil and grease \\
Silver & SVOCs \\
Zinc & VOCs \\
NOTE: VOCs $=$ volatile organic compounds \\
\multicolumn{2}{r}{ SVOCs $=$ semi-volatile organic compounds }
\end{tabular}

Results of sampling are contained in the Wastewater Monitoring Program Monthly Reports, available upon request. Other important documents to the program are listed in table 6-3.

\subsubsection{Summary of Monitoring Results}

All laboratory sampling results in 1997 showed SNL/NM was in compliance the COA's "Sewer Use and Wastewater Control Ordinance." The 1997 wastewater results, with respect to meeting permit requirements, are documented in the Wastewater Monitoring Program Semiannual Reports for 1997. There were several $\mathrm{pH}$ excursions above regulatory limits described below. Each excursion was reported to both the DOE and the COA.

Permit 2069A-3, General Station WW001 - A $\mathrm{pH}$ excursion occurred on May 14, 1997, for over 1 hour. No fines were incurred.
Permit 2069F-3, General Station WW006 On March 11, 1997, a pH excursion above 11 occurred for over 1 hour. No fines were incurred.

Permit 2069G-3, Station WW007 at the MDL - No violations.

Permit 2069H-3, Station WW009 at the AMPL - On January 28, 1997, a pH excursion occurred for approximately 5 hours. It was later determined that a faulty probe gave incorrect readings. No fines were incurred.

Permit 2069I-2, General Station WW008 No violations.

Permit 2069K-2, General Station WW011No violations.

\section{SURFACE DISCHARGE PROGRAM}

All discharges to the ground surface are evaluated for compliance with New Mexico Water Quality Control Commission (NMWQCC) regulations as implemented by the NMED's Groundwater Bureau. The primary drivers are listed in table 6-4. The Surface Discharge Program also follows the requirements of DOE Orders 5400.1 and 5400.5 (DOE 1990a, DOE 1993a). Important documents for the program are listed in table 6-5.

TABLE 6-3. Important Documents for the Wastewater Discharge Program

\begin{tabular}{|l|l|}
\hline Program Document & Reference \\
\hline Semi-annual Reports (July 31, 1997 and January 31,1998) & No reference \\
\hline Section 10H-“Discharge to the Sanitary Sewer," from the ES\&H Manual. & SNL 1998j \\
\hline SNL/NM Wastewater Sampling and Analysis Plan & SNL 1996k \\
\hline Septic Tank Sampling Project Waste Management Plan & SNL 1995h \\
\hline Water Quality (PG) & SNL 1997k \\
\hline
\end{tabular}

NOTE: PG denotes a "Program Document," which is a specific type of ES\&H document. 
Surface discharges are made only after consultation with, and approval by, SNL/NM's Environmental and Emergency Management Department. This department assists facility owners in meeting surface discharge requirements set forth by the state. All surface discharges must be documented through the request process. Source contaminants present, if any, must meet strict guidelines before water can be released to roads, open areas, or impoundments. (Even uncontaminated water must go through the request process; if water is disposed of in an improper area, it may increase infiltration of contaminants already present in the soil.) In 1997, 36 individual requests for discharges were made; 29 were approved and the remaining seven were sent to the sanitary sewer system authority for approval and disposal. All approved discharges to the ground surface were in full compliance with New Mexico water quality standards.

TABLE 6-4. Primary Regulatory Drivers for the Surface Discharge Program

\begin{tabular}{|l|l|}
\hline \multicolumn{1}{|c|}{ Regulation } & \multicolumn{1}{c|}{ Citation } \\
\hline $\begin{array}{l}\text { Clean Water Act } \\
\text { (CWA) }\end{array}$ & $\begin{array}{l}\text { Title 33, U.S.C. 1251 } \\
\text { (Monitoring \& Reporting } \\
\text { Requirements) }\end{array}$ \\
\hline 40 CFR 112 & Oil Pollution Prevention \\
\hline NMWQCC Regs & 20 NMAC 6.2 \\
\hline
\end{tabular}

\section{Pulsed Power Evaporation Lagoons}

SNL/NM maintains two large lined discharge lagoons to support the operations at the Pulsed Power Development Facilities in TA-IV. The lagoons are used to collect and evaporate large quantities of storm water pumped from containments around the facility's oil storage tanks. Additionally, runoff water derived from condensation and cleaning may accumulate in several indoor floor containment trenches and is also pumped to the lagoons for evaporation. Oil is the primary contaminant that may be found in the discharged water. Any visible oil is skimmed off before water is discharged to the lagoons. Due to the ongoing nature of the discharges and the large volumes of water involved, a formal plan that also contains the necessary permit is registered with NMED (Discharge Plan DP-530).

Lagoon $I$ is a 137,500 -gallon capacity rectangular pond $50 \mathrm{ft}$ by $70 \mathrm{ft}$ in area and $11 \mathrm{ft}$ deep. Lagoon II is a 127,000-gallon capacity trapezoidal shaped pond approximately $40 \mathrm{ft}$ by $70 \mathrm{ft}$ in area and $8 \mathrm{ft}$ deep. The Discharge Plan/Permit requires semi-annual water quality analysis and water level measurements.

\section{Lagoon Sampling Results}

Water level measurements and water quality samples were taken in June and December of 1997.

Due to the limited surface area (less than 1,000 sq $\mathrm{ft}$ ) and depth, grab samples from the surface are considered representative for water quality analysis. Direct measures were also made of $\mathrm{pH}$ and specific conductance at the time of sampling. Parameters measured, as required by

TABLE 6-5. Important Documents for the Surface Discharge Program

\begin{tabular}{|l|l|}
\hline Program Document & Reference \\
\hline $\begin{array}{l}\text { Sampling and Analysis Plan for the Pulsed Power Development Facilities, } \\
\text { Buildings. 981, 98, and 970, for Lagoons 1 and 2 }\end{array}$ & SNL 19961 \\
\hline Section 10 F -“Oils, Greases, and Fuels," from the ES\&H Manual & SNL 1998i \\
\hline Section 10T - "Surface and Storm Water Discharges,” from the ES\&HManual & SNL 19981 \\
\hline Oil Spill Prevention Control and Countermeasure (SPCC) Plan & CDM 1995 \\
\hline Discharge Plan Modification and Renewal, DP-530, SNL/NM & NMED 1995 \\
\hline DP-530 Semi-Annual Report & SNL 19971 \\
\hline
\end{tabular}


the permit, include total dissolved solids (TDS), chloride, sulfates, and various other major ions. Additionally, SNL/NM analyzes the water for calcium, sodium, magnesium, potassium, calcium carbonate, and VOCs.

Water level measurements are taken biannually. On June 9, 1997, Lagoon I was 57 percent of capacity and Lagoon II was 5 percent of capacity. On December 3, 1997, Lagoon I was 74 percent of capacity and Lagoon II was 15 percent of capacity.

Complete water quality and water measurement results are reported to the State of New Mexico 6 months after each sampling event. All permit requirements were met in 1997; results are recorded in the DP-530 Semi-annual Report (SNL 19971).

\section{Surface Discharge Activities}

Five releases to the environment involving contaminated surface water occurred in 1997. (Details are given in section 2.5.)

- June 9 - A tank at the Large Melt Facility (LMF) leaked 475 gal of cooling water.

- June 14 - A treated water supply line broke releasing 15,000-20,000 gal.

- July 29 - A bank at an Environmental Restoration (ER) site eroded resulting in the release of depleted uranium (DU).

- October 25 - A sewage holding tank overflowed releasing 7,500-10,000 gal.

- November 12 - A sewer line break released up to 100 gal of sewage.

\section{3 soom marer PROGRAM}

SNL/NM has implemented its Storm Water Program in compliance with its National Pollutant Discharge Elimination System (NPDES) Permit to protect "U.S. Surface Waters" as defined in the Clean Water Act (CWA). By this definition, it has been determined that the Tijeras Arroyo is a "U.S. Surface Water." Therefore, at SNL/NM, any runoff discharging to the Tijeras Arroyo from storm drain conduits, channels, arroyos, ditches, or surface flow is defined as a discharge point and is subject to NPDES Permit conditions. Tijeras Arroyo drains through SNL/NM before emptying into the Rio Grande about $14 \mathrm{~km}$ $(8.7 \mathrm{mi})$ to the west. The primary drivers for SNL/NM's Storm Water Program are listed in table 6-6.

Storm water runoff at SNL/NM is collected in culverts, channels, arroyos, and other drainages from paved streets, dirt roads, landscaped areas, buildings, and industrial sites. Depending on the surface contaminants present, storm water may include vehicle exhaust and engine oil residue, air pollutant deposits, heavy metals, pesticides, and fertilizers.

SNL/NM facilities with hazardous and toxic materials stored onsite, such as may be present at waste management facilities, and oil or chemical storage areas, are configured to prevent storm water from discharging directly to

TABLE 6-6. Primary Regulatory Drivers for the Storm Water Program

\begin{tabular}{|l|l|}
\hline Regulation & Citation \\
\hline $\begin{array}{l}\text { National Pollutant Discharge Elimination System (NPDES) } \\
\text { Regulations }\end{array}$ & 40 CFR 122-125 \\
\hline $\begin{array}{l}\text { Guidelines Establishing Test Procedures for the Analysis of } \\
\text { Pollutants }\end{array}$ & 40 CFR 136 \\
\hline NMWQCC Regulations (New Mexico Water Quality Act) & 20 NMAC 6.2 \\
\hline
\end{tabular}


the storm water system. These facilities are equipped with sloped pads, containment berms, and/or curbing to direct storm water into containments ponds where it can evaporate or be released after it has been determined that it meets regulatory criteria. Storm water monitoring stations are shown in figure 6-2.

Currently, only TA-I, TA-II, and TA-IV have the capacity to generate storm water runoff that discharges directly to Tijeras Arroyo. These areas require storm water monitoring.

In the Lurance and Coyote Canyon test areas, there are several arroyos that do converge with Tijeras Arroyo off SNL/NM property. However, current SNL/NM activities at these test areas do not require storm water monitoring. Storm water runoff produced in TA-III and TA-V does not travel all the way to Tijeras Arroyo. Runoff is quickly absorbed into the sandy alluvium. This is also true for test areas further south.

\subsubsection{Storm Water Program Activities}

Routine inspections of ditches and arroyos are required under the NPDES permit. SNL/NM conducts dry weather inspections to detect any illicit discharges. The storm drain system is also inspected routinely for debris such as vegetation buildup and trash. All debris is cleaned out on an annual basis, or as necessary. During storm events, wet inspections are conducted to check for broken levees, floating debris, and to note water characteristics, such as clarity, foaminess, and color.

The discharge of any pollutant to "Waters of the U.S." is prohibited by the CWA unless the discharge is specifically permitted. SNL/NM's

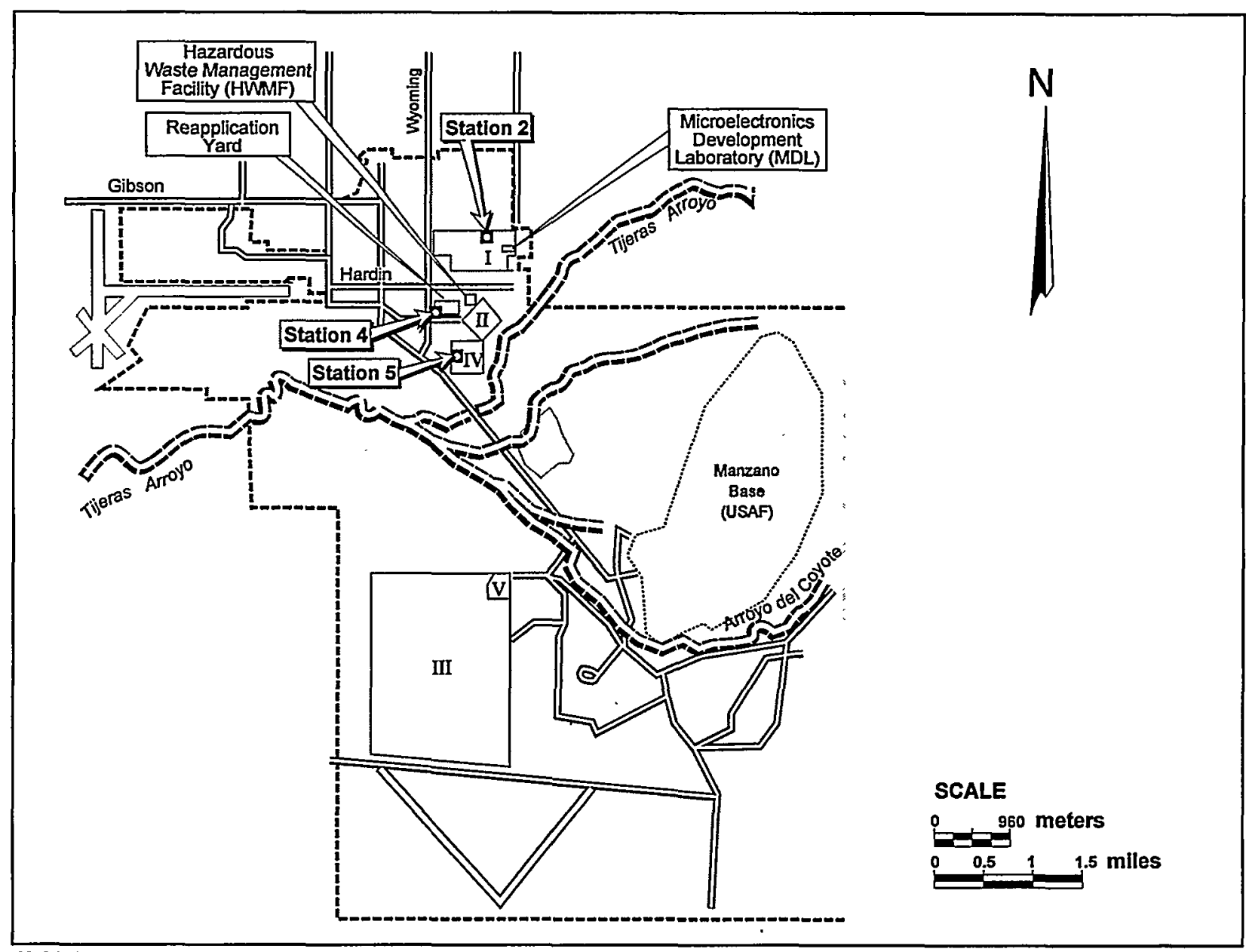


permit is for the discharge of storm water only. In certain circumstances discharges other than storm water may be made to the storm drain system. Discharges are reviewed by the Environmental and Emergency Management Department to ensure compliance with the NPDES permit.

Several other environmental programs at SNL/NM work cooperatively to ensure that storm water runoff meets or exceeds regulatory standards. These include the Pollution Prevention Program, the Environmental Restoration (ER) Project, the Surface Discharge Program, and program activities conducted under the Oil Spill Prevention Control and Countermeasures (SPCC) Plan (CDM 1995).

Storm water runoff from construction sites exceeding 5 acres is permitted under the NPDES Construction Storm Water Permitting regulations. Affected construction projects have individual Storm Water Pollution Prevention Plans that impose requirements specific to each site. SNL/NM mitigates potential storm water pollution from construction sites by implementing the use of silt fences and adhering to strict guidelines to prevent contamination from various construction materials and processes. Once the construction project has been completed, open areas may be reseeded, xeriscaped, or asphalted to prevent the transport of residual pollutants and erosion.

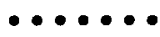

\subsubsection{NPDES Permit Application}

The EPA requires an NPDES Storm Water Permit for all industrial facilities that have processes defined in the Standard Industrial Classification (SIC) codes listed in Appendix A of 40 CFR 122. SNL/NM has four "primary industrial" activities as defined in the regulation:

1. Any construction or disturbance of over five acres
2. Electronics manufacturing (applies to the Microelectronics Development Laboratory (MDL)

3. Hazardous materials treatment, storage, or disposal (TSD) (applies to the HWMF)

4. Scrap and waste recycling facilities (applies to SNL's Reapplication Yard)

The only active construction permit in 1997 was for the Technical Support Center. It was terminated in August when soil stabilization through revegetation was sufficiently established.

\section{Historical NPDES Permit Status}

After 5 years of waiting, SNL/NM was granted an NPDES storm water permit in August 1997.

In 1992, SNL/NM submitted an "Individual" storm water permit to the EPA. The permit was specifically tailored to address all facilities at the site and proposed nine storm water monitoring stations. However, due to the backlog at the EPA in processing these types of permits, the permit application was still pending in 1996. After reviewing its site activities, SNL/NM determined that a more simplistic "Multi-sector General Permit" would adequately cover storm water monitoring requirements. A new application was submitted to the EPA in September 1996 proposing two monitoring stations. The new permit application was also more specific in listing regulated pollutant levels in storm water, and it limited the parameter list to industry-specific pollutants. SNL/NM left the original "Individual" permit pending while a determination was made by the EPA on the new "Multisector General" permit.

In anticipation of issuance of the new permit, SNL/NM suspended storm water sampling for the first half of 1997. In July, the stations were re-activated to prepare for sampling. However, since samples were taken before the permit was in effect (August), the limits set in the permit did not apply. 
Currently, NMED and EPA jointly provide oversight of NPDES regulations. However, it is likely that the EPA will delegate complete authority to the State of New Mexico by the year 2000 .

\subsubsection{Storm Water Monitoring Stations}

SNL/NM conducted storm water monitoring at Stations 4 and 5 (Figure 6-2). Station 5 monitors runoff from the majority of SNL/NM's industrial activities including the Hazardous Waste Management Facility (HWMF) and the Microelectronics Development Laboratory (MDL). Station 4 primarily monitors runoff from SNL/NM's Reapplication Yard.

The Multi-Sector General Permit requires sampling four times per year every 2 years, weather permitting. Due to Albuquerque's semi-arid climate and high infiltration rates, precipitation rarely produces adequate runoff for monitoring in the months of October through March. In general, most storm water sampling occurs during the rainy season from April through September. After a rainfall of sufficient intensity and duration (as defined in the regulation), storm water runoff flowing through each station is collected by grab sampling. Rainfall quantity is also measured at each site and the data is shared with the National Weather Service.

\subsubsection{Storm Water Monitoring Results}

Equipment problems plagued sampling attempts in 1997. As a result, only one storm water event was sampled. The analytical results presented in table 6-7 show that iron and zinc exceeded permit limits at both stations by a large margin. Only one set of samples was taken from each station. Although one data point is not statistically significant, the analysis indicates that there could be a potential problem. SNL/NM staff inspected storm water drainage systems and facilities upstream of the sampling stations to determine if there were identifiable potential sources of iron and zinc. No sources were found.

The total suspended solids (TSS) were also above limits, although this is likely a sampling configuration problem caused by collecting excess sediment from the bottom of the channel. Both Stations 4 and 5 are situated on open nonlined drainage channels. Water levels are very shallow through these channels due to the low rate of runoff (from high infiltration rates). To ensure a sufficient sample, the storm water intake tube is placed at the bottom of the drainage channel, resulting in the uptake of silt off the bottom of the channel when the samplers are activated. The silt in the sample would result in an abnormally high value for the TSS, since the analytical laboratory would assume the silt was in suspension and measure it as such. Depending on the composition of the silt (mineralogy), the analytical results for metals could be skewed as well.

In the future, attempts will be made to obtain more representative samples (although this will be difficult due to typically low flows). If future sampling indicates SNL/NM is discharging metals above permit limits, further investigations will be conducted to determine the source and eliminate them, if possible.

Important documents to the program are listed in table 6-8. 
TABLE 6-7. 1997 Sampling Results for Storm Water Stations 4 and 5

\begin{tabular}{|c|c|c|c|}
\hline Parameter & Station 4 & Station 5 & Permit Limit \\
\hline \multicolumn{4}{|l|}{ METALS (mq/l) } \\
\hline Ammonia & 0.5 & 0.81 & 19.0 \\
\hline Cyanide & 0.00174 & 0.00507 & 0.0636 \\
\hline Aluminum & 30.3 & 18.5 & 0.75 \\
\hline Arsenic & 0.0119 & 0.0159 & 0.16854 \\
\hline Barium & 0.58 & 1.19 & 1.0 \\
\hline Cadmium & 0.00127 & 0.00282 & 0.05 \\
\hline Chromium & 0.0251 & 0.0152 & 0.5 \\
\hline Copper & 0.0462 & 0.0552 & 0.0636 \\
\hline Iron & 23.7 & 12.9 & 1.0 \\
\hline Lead & 0.037 & 0.0882 & 0.0816 \\
\hline Magnesium & 14.0 & 18.9 & 0.0636 \\
\hline Manganese & 0.637 & 0.988 & - \\
\hline Mercury & ND & 0.000156 & 0.0024 \\
\hline Nickel & 0.0241 & 0.0249 & - \\
\hline Selenium & 0.00236 & 0.00392 & 0.2385 \\
\hline Silver & 0.00304 & ND & 0.0318 \\
\hline Zinc & 0.191 & 0.271 & 0.065 \\
\hline \multicolumn{4}{|l|}{ NON-METALS (mg/l) } \\
\hline Nitrate + Nitrite & 0.5 & 0.81 & 0.68 \\
\hline Total kjeldahl nitrogen & 3.48 & 0.89 & - \\
\hline Oil and grease & ND & ND & - \\
\hline Chemical oxygen demand & 108 & 158 & 120 \\
\hline Total suspended solids & 1660 & 1170 & 100 \\
\hline \multicolumn{4}{|l|}{ RADIOLOGY (pCill) } \\
\hline Gross alpha & 9.91 & 29.5 & \\
\hline Gross beta & 16.5 & 26.3 & \\
\hline \multicolumn{4}{|l|}{ EXPLOSIVES $^{*}(\mathrm{mg} / \mathrm{l})$} \\
\hline HMX & ND & ND & none \\
\hline RDX & ND & ND & none \\
\hline 1,3,5-trinitrobenzene & ND & ND & none \\
\hline 1,3-dinitrobenzene & ND & ND & none \\
\hline Tetryl & $\mathrm{ND}$ & ND & none \\
\hline Nitrobenzene & ND & ND & none \\
\hline 2,4,6-trinitrotolunene & ND & ND & none \\
\hline 4-Amino-2,6-dintrotoluene & ND & ND & none \\
\hline 2-Amino-4,6-dinitrotoluene & $\mathrm{ND}$ & ND & none \\
\hline 2,6-dinitrotoluene & $\mathrm{ND}$ & ND & none \\
\hline 2,4-dinitrotoluene & ND & ND & none \\
\hline 2-nitrotoluene & ND & ND & none \\
\hline 4-nitrotoluene & ND & $\mathrm{ND}$ & none \\
\hline 3-nitrotolune & ND & $\mathrm{ND}$ & none \\
\hline
\end{tabular}

NOTE: $J=$ Detected below the reporting limit or is an estimated concentration

$\mathrm{B}=$ Detected in the blank above the effective minimum detection limit (MDL)

ND $=$ Not detected

*There are no set limits for explosive constituents. Sandia performs this parameter check at the request of the State of New Mexico.

All sampling was conducted on July 11, 1997. 
TABLE 6-8. Important Documents for the Storm Water Program

\begin{tabular}{|l|l|}
\hline Program Document & Reference \\
\hline Results of 1997 Storm Water Sampling & SNL 1998p \\
\hline Storm Water and Non-Storm Water Discharge Sampling and Analysis Project Plan for SNL/NM & SNL 1996m \\
\hline Section 10T-"Surface and Storm Water Discharges," from the ES\&H Manual & SNL 19981 \\
\hline
\end{tabular}




\section{7 \\ Groundwater Monitoring AND Protection Programs

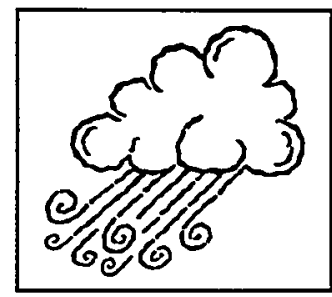

7 his chapter describes the groundwater monitoring activities conducted at SNL/NM during 1997. Groundwater monitoring activities reported are those associated with two programs at SNL/NM: the Groundwater Protection Program (GWPP) and the Environmental Restoration (ER) Project. Regulations specific to the two task areas are shown in table 7-1.

The Groundwater Surveillance Task Group is the groundwater monitoring function of the GWPP. This task performs site-wide water quality and water level measurements to establish baseline information on the groundwater system in the vicinity of SNL/NM. SNL/NM conducts groundwater monitoring to determine the impact, if any, on local groundwater quality and quantity as a result of its operations, and to demonstrate compliance with all federal, state, and local groundwater requirements.

The ER Project is concerned with the determination of the nature and extent of groundwater contamination, if any, at specific sites at SNL/NM where past activities resulted in environmental contamination. In areas where contaminant migration has reached groundwater levels, the extent of the contaminant plume is being characterized through routine water level and water quality sampling.

The specific task areas performed for groundwater monitoring in 1997 are illustrated in figure 7-1. All groundwater results determined by the Groundwater Surveillance Task and the ER Project Task are summarized in this chapter with respect to water level and water quality results. The first section of this chapter describes water levels and general groundwater trends. The second half of the chapter describes water quality and presents a summary of contaminants found in concentrations above federal and state standards or DOE guidelines, as applicable.

\subsection{GROUNDWATER PROGRAM}

Groundwater Protection Program (GWPP)

The Groundwater Surveillance Task collects annual water quality samples. Groundwater level measurements are collected monthly and quarterly and are used to infer the direction and rate of groundwater flow at KAFB. Water quality data are used in baseline hydrogeochemical characterization and groundwater contamination detection monitoring. Wells in the GWPP network are selected to provide representative water samples for areas of SNL/NM based on historical water quality data. Figure 7-2 shows the network of wells used to monitor water quality and water levels. In 1997, nine wells and one spring were sampled for water quality. Water levels were measured in 123 wells (GWPP, ER, KAFB, and city wells). Some wells in the GWPP serve both functions.

Groundwater surveillance at SNL/NM is conducted in accordance with the requirements of Department of Energy Order 5400.1, General 
Environmental Protection Program (DOE 1990a). The GWPP has designed its surveillance activities to conform with groundwater regulations defined in 40 CFR 265, Subpart F, under the Resource Conservation and Recovery Act (RCRA).

\section{Environmental Restoration (ER) Project}

The ER Project collects groundwater level and water quality data at sites identified as having the potential for groundwater contamination associated with past hazardous waste disposal activities. These sites are managed in accordance with RCRA requirements detailed in table 7-1.

ER site investigations are conducted as part of the site-specific activities under the Hazardous and Solid Waste Amendments (HSWA) permit for SNL/NM. The HSWA requires that the RCRA process for investigating operating disposal facilities be applied to non-operating facilities. That is, investigations are carried out at the facilities using the RCRA facility investigation ( $\mathrm{RFI}$ ) process. RFI activities have been conducted in accordance with RFI work plans that are awaiting EPA approval. These preliminary activities have been designed to determine the amount and extent of any potential contamination in anticipation of formal RFI activities. Once the RFI process is complete, corrective measures can be initiated as needed.

Currently, there are five general ER areas with groundwater issues:

- Chemical Waste Landfill (CWL)

- Mixed Waste Landfill (MWL)

- Technical Area-V (TA-V)

- Canyons Test Area

- Sandia North (includes TA-I and TA-II)

Each area conducts groundwater monitoring in accordance with site-specific sampling and analysis plans.

The following gives a brief description of the general contamination present and the number of active monitoring wells located at each site:

- Chemical Waste Landfill - The principal contaminant at this site is trichloroethene (TCE). TCE was disposed of in unlined pits at the landfill up until 1985 when the landfill was closed and came under RCRA regulation for past disposal sites. Other

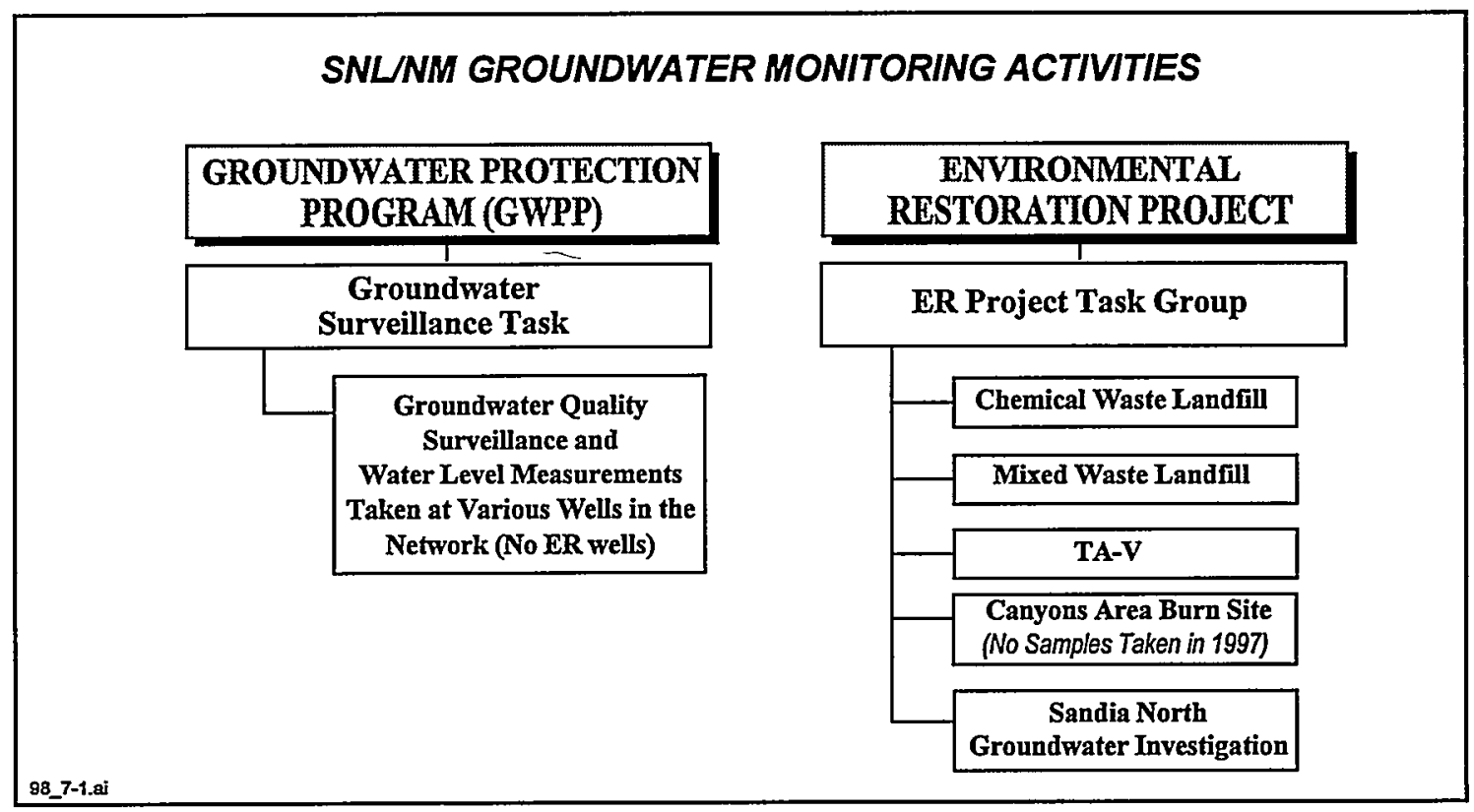

FIGURE 7-1. Organizational Structure of Groundwater Monitoring Activities in 1997 
groundwater contamination identified at the CWL includes thallium, antimony, iron, and nickel. In 1997, samples were collected quarterly as required by the CWL Closure Plan. There are 14 monitoring wells at the CWL; 12 were sampled in 1997. Vapor extraction has been started at the site to remove TCE from the soil as part of the voluntary corrective measures (VCM) implemented at the site.

- Mixed Waste Landfill - The MWL is primarily a tritium-contaminated site resulting from the past disposal of reactor coolant water. However, to present, no contaminants have been detected in the groundwater. All five monitoring wells located at this site were sampled in 1997.

- TA-V - Contaminants present include primarily volatile organic compounds (VOCs) such as TCE. There are nine wells in the TA-V area; three of these wells were installed in 1997. The TA-V monitoring wells also include those that monitor the
Liquid Waste Disposal System (LWDS) site. Six wells were sampled in 1997.

- Canyons Test Area - Elevated nitrate levels have been found at the Burn Site Well located in Lurance Canyon. At present, this is the only ER site in the canyons where groundwater contamination is suspected. The ER project is currently working with the New Mexico Environment Department (NMED) to define additional groundwater investigation activities at the Burn Site. Two new wells were installed to characterize groundwater contamination. Samples were taken late in 1997 from the Burn Site Well, but the results are not available for inclusion in this report.

- Sandia North - This area includes ER sites in TA-I and TA-II. Sandia North is unique among ER sites in the existence of a shallow water-bearing zone elevated above the regional groundwater system. Groundwater contamination includes TCE and nitrates, both of which have been detected at

TABLE 7-1. Regulations Specific to the Groundwater Protection Program and the ER Project

\begin{tabular}{|c|c|c|}
\hline Regulation & Citation & Note \\
\hline \multicolumn{3}{|l|}{ Regulations specific to the GWPP } \\
\hline Groundwater and Surface Water Protection & 20 NMAC 6.2 & $\begin{array}{l}\text { New Mexico water quality } \\
\text { standards }\end{array}$ \\
\hline Drinking Water & $20 \mathrm{NMAC} 7.1$ & $\begin{array}{l}\text { New Mexico water quality } \\
\text { standards }\end{array}$ \\
\hline National Primary Drinking Water Regulations & 40 CFR 141 & Federal standards \\
\hline \multicolumn{3}{|l|}{ Regulations specific to ER Sites } \\
\hline $\begin{array}{l}\text { RCRA Groundwater Monitoring Regulations (for } \\
\text { interim status sites) }\end{array}$ & $\begin{array}{l}40 \text { CFR 265, } \\
\text { Subpart F }\end{array}$ & $\begin{array}{l}\text { Applies to the CWL operating } \\
\text { under the CWL Closure Plan }\end{array}$ \\
\hline $\begin{array}{l}\text { Corrective Action for Solid Waste Management } \\
\text { Units (SWMU)* }\end{array}$ & $\begin{array}{l}40 \text { CFR 264, } \\
\text { Subpart F, Section } \\
264.101\end{array}$ & $\begin{array}{l}\text { All other ER sites (excluding } \\
\text { CWL), which are under RCRA's } \\
\text { SWMU Corrective Action } \\
\text { requirements }\end{array}$ \\
\hline General Environmental Protection Program & DOE Order 5400.1 & $\begin{array}{l}\text { Directs groundwater surveillance } \\
\text { activities }\end{array}$ \\
\hline
\end{tabular}

NOTE: *As required by the Hazardous and Solid Waste Amendments (HSWA) Module to the RCRA Permit. 


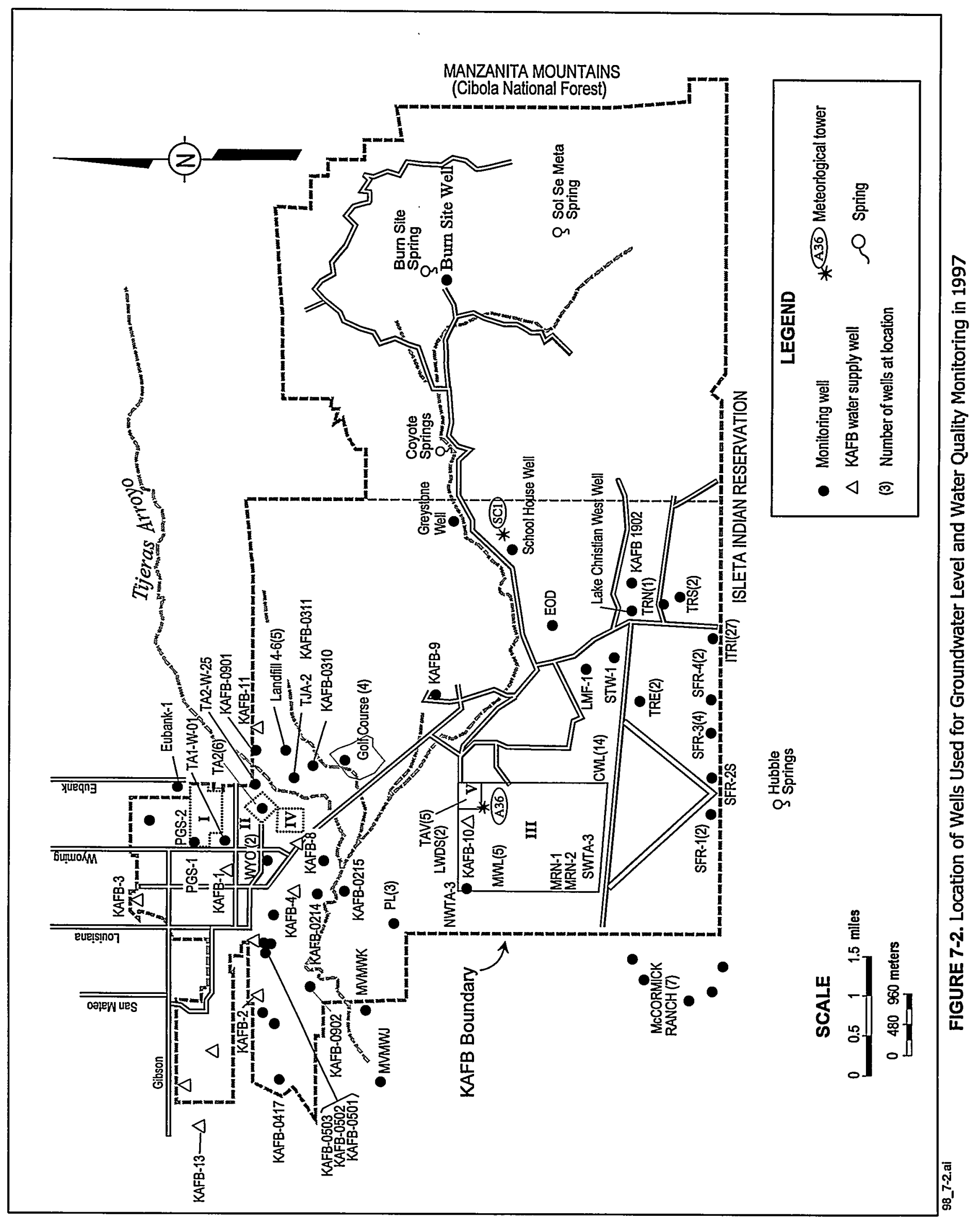


concentrations exceeding drinking water criteria. There are 14 wells in the Sandia North area; eight regional aquifer wells (including two new ones added in 1997) and six shallow waterbearing wells. Eleven wells were sampled in 1997.

\section{2 water level tRends}

Water level measurement activities were performed during 1997 by both the Groundwater Surveillance Task and the ER Project. Additional data was gathered from wells monitored by the Kirtland Installation Restoration Program (IRP) and the City of Albuquerque (COA). A total of 123 wells monitored by all four agencies were measured on a monthly and quarterly basis:

- 43 wells by GWPP

- 39 wells by ER Project

- 38 wells by IRP

- 4 wells by COA

The Groundwater Surveillance Task and the ER Project Task measure water levels to establish groundwater gradients and infer the direction of groundwater flow. This information is vital to understanding the migration of contaminants in groundwater and their potential impacts. Water level information is also necessary to determine the future utility of existing monitor wells. Since well screens penetrate only a limited distance below the water table, the continuing decline of the water table will render some of these wells useless in the near future when the screens no longer intercept the water table. Selected water data from these wells were used to construct a potentiometric surface map for groundwater flow determination.

The dynamics of water table fluctuations, as reflected by water levels in individual wells, are a balance of the water recharge to the groundwater system, the withdrawal from the system, and the properties of the aquifer materials. The quantity and location of local recharge to the aquifer on the east side of the Tijeras fault complex is not very well understood or documented (Figure 7-3). This is due to few wells in the area, as well as the complex geology. Recharge sources to the basin are from regional precipitation-the greatest amount of which occurs in the mountains on the eastern boundary of KAFB - and the Rio Grande several miles west of KAFB. Withdrawal of groundwater at KAFB is discussed in section 7.3.4.

\section{Water level trends}

In general, the hydrographs indicate water levels have been declining at KAFB as a result of water supply pumping from COA and KAFB water supply wells. The primary aquifer, within the upper unit of the Santa Fe Group, shows a rate of decline at between $0.5 \mathrm{ft}$ to over $2 \mathrm{ft}$ per year. Most of the COA and KAFB water supply wells produce from coarser-grained layers of the upper and middle units of the Santa Fe Group. Water level information, with respect to the regional water table in the KAFB area, can be categorized into three general areas as shown in figure 7-3.

\section{Vicinity of TA-III}

The "Vicinity of TA-III" comprises the monitor wells within and around TA-III and TA-V, including the CWL and the MWL. These wells are screened within the regional Santa Fe Group aquifer. In general, water levels do not show significant seasonal fluctuations but do show relatively steady declines that are consistent with basin-wide declines.

\section{Sandia North Area}

The "Sandia North Area" includes wells in the area or TA-I, TA-II, the Tijeras Arroyo, and west of TA-II. Both the regional aquifer and a shallow water-bearing zone are monitored near TA-I and TA-II. In this area, monitor wells, which are completed within the regional aquifer, demonstrate a seasonal fluctuation coincident with the water supply pumping at the active water supply wells suggesting that these wells 


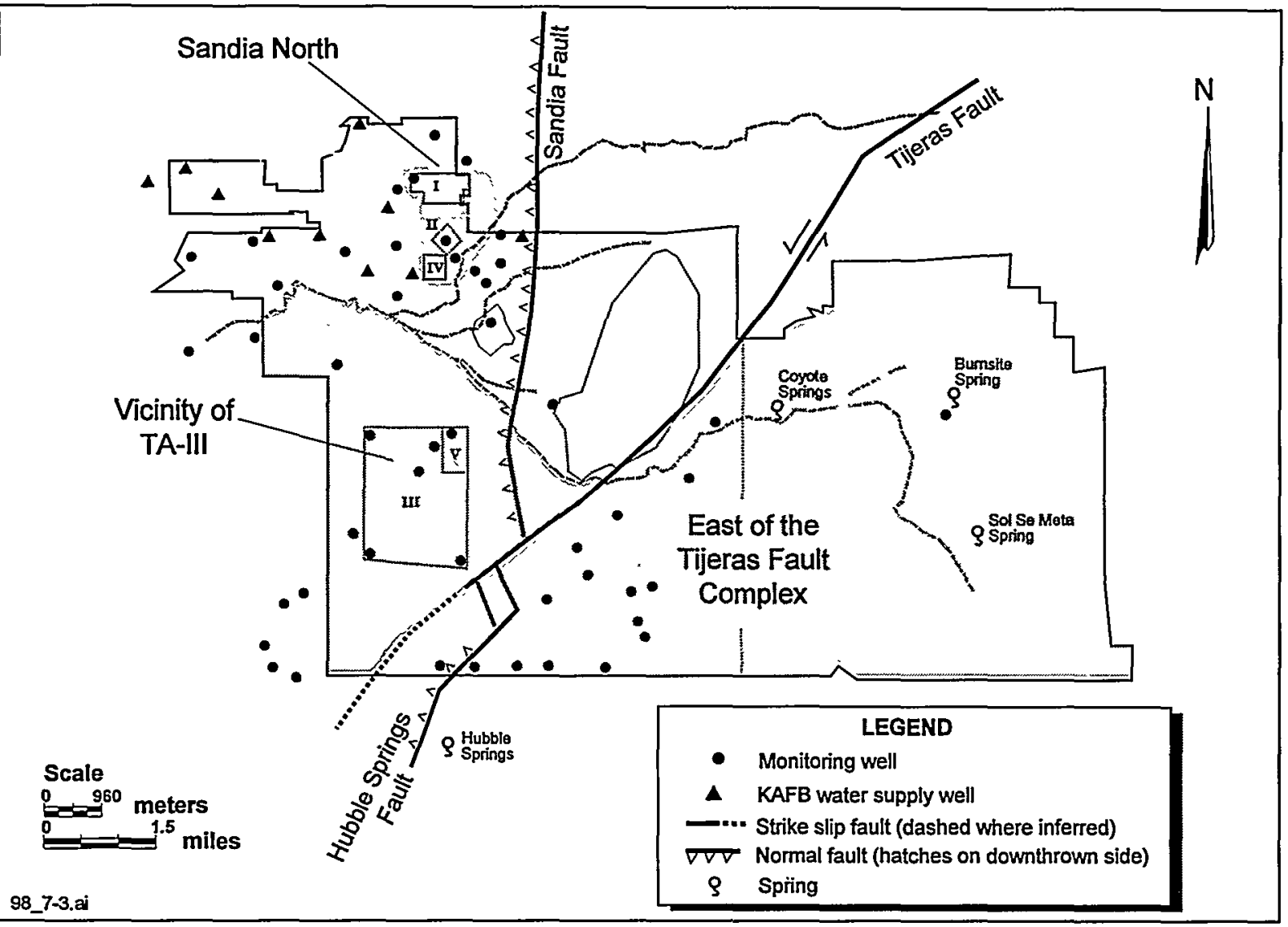

FIGURE 7-3. Areas (Shaded) on KAFB with Distinct Water Level Trends

are within the radius of influence of water withdrawal wells. Wells in this area also show consistent, significant declines in water levels through the year as a result of basin-wide water level declines. The area in the vicinity of the golf course has elevated groundwater levels that may be connected to the shallow water-bearing zone observed to the north and west. Water levels in this area are increasing, probably due to the recharge resulting from the golf course irrigation.

\section{East of the Tijeras Fault Complex}

"East of the Tijeras Fault Complex" includes wells along the southern boundary of KAFB, wells within Coyote and Lurance canyons, and wells near the Lovelace Respiratory Research Institute (LRRI). Water levels in this area are not affected by the basin-wide water level declines within the Santa $\mathrm{Fe}$ Group aquifer system. Because of the proximity to recharge sources (mountain fronts) in the region east of the fault complex, water levels show seasonal fluctuations that probably reflect recharge from precipitation and runoff.

\subsubsection{Water Level Trends in the Vicinity of TA-III}

TA-III vicinity wells include CWL wells, MWL wells, the wells located along the western boundary of TA-III, and wells in and around TA-V.

Chemical Waste Landfill - The depth to water at the CWL ranges from 482 to $495 \mathrm{ft}$ below ground level. Water levels in general are continuing to decline at approximately 0.3 $0.9 \mathrm{ft} / \mathrm{yr}$.

All wells measured in 1997, represented by more than two measurement points, decreased in 
water level elevations through August and increased thereafter with the exception of wells CWL-BW4A and CWL-BW3. These two wells are located at the eastern portion of the CWL. The eastern-most wells increased slightly from May through August and declined approximately $0.9 \mathrm{ft}$ between, August and November.

Several nested wells were installed to determine the vertical gradient at the CWL. Water levels in the nested wells indicate a downward vertical gradient at the CWL of approximately 0.07 foot per foot within top $50 \mathrm{ft}$ of saturation. The downward vertical gradient indicates preferential flow through coarser materials that are present deeper in the strata.

Mixed Waste Landfill - Water levels were measured on a monthly schedule from four MWL monitor wells in 1997. During the year, water levels in MWL monitor wells declined an average of $0.64 \mathrm{ft} / \mathrm{yr}$. Although on average, water levels declined during the year, several months showed increases in water levels.

TA-V - Water levels were measured and recorded monthly in all nine TA-V monitor wells during 1997. All wells at TA-V showed some variability from month to month, due to barometric pressure fluctuations, but in general water levels declined an average of $0.24 \mathrm{ft} / \mathrm{yr}$ in 1997. This is slightly lower than the average historical rate of decline for all TA-V wells, which has been $0.39 \mathrm{ft} / \mathrm{yr}$.

Vicinity of TA-III - Seven wells were measured quarterly in the vicinity of TA-III around and outside the perimeter to the west. Water levels recorded in 1997 rose very slightly between March and June of 1997 in all wells and water level declines in these wells were highest between June and July. Water levels declined during 1997 on average of $1.5 \mathrm{ft} / \mathrm{yr}$. This is significantly higher than at the MWL and CWL sites and indicates a high lateral heterogeneity from east to west across KAFB.

\subsubsection{Water Level Trends in the Vicinity of Sandia North}

Wells in the Sandia North area include TA-I, TA-II, the Tijeras Arroyo Golf Course area, middle Tijeras Arroyo, and wells around the former KAFB sanitary waste lagoons. The regional aquifer under TA-I and TA-II is encountered approximately $540 \mathrm{ft}$ below ground surface. This area also has a shallow waterbearing zone with water levels at $270 \mathrm{ft}$ and 320 $\mathrm{ft}$ below the surface.

Sandia North - Fourteen monitor wells were measured monthly in the Sandia North area in 1997. Six monitor wells are screened in the shallow water-bearing zone. Eight monitor wells are screened in the regional aquifer, including two new wells installed in April 1997.

Groundwater levels in each regional well remained consistent, averaging a decline rate of $0.40 \mathrm{ft} / \mathrm{yr}$ throughout 1997 except for PGS-2. PGS-2 declined $3.25 \mathrm{ft}$ in January and November in concert with the pumping schedule of a nearby KAFB water supply well. KAFB0311 increased slightly by $0.05 \mathrm{ft} / \mathrm{yr}$. Groundwater levels in each of the shallow water-bearing zone wells remained consistent throughout 1997.

Tijeras Arroyo Golf Course - Four wells are located in the Tijeras Arroyo Golf Course area. Groundwater is first encountered beneath the Tijeras Arroyo Golf Course at approximately $130 \mathrm{ft}$ above the projected regional groundwater surface at this location. The apparent direction of groundwater flow in this shallow zone is south to southeast. The overall increase in water level elevation was $0.95 \mathrm{ft} / \mathrm{yr}$. Long-term hydrographs of these wells show a continued rise in water levels, as in previous years. The 1991 through 1998 average rates of water level rises are $1.98 \mathrm{ft} / \mathrm{yr}$. Although recharge from the golf course irrigation is a possible source of the increasing water levels, it is currently unknown if this is the cause. Recharge may also be occurring from potential sources to the northwest. Also the hydraulic connection 
between the groundwater level at the golf course and the shallow water-bearing zones to the northwest of Sandia North is currently unknown. Figure 7-4 illustrates the extent of the shallow water-bearing zones as currently defined.

Tijeras Arroyo - The wells near the Tijeras Arroyo generally show steady water level declines ranging from $1.8 \mathrm{ft} / \mathrm{yr}$ in the western portion of the Tijeras Arroyo to $0.47 \mathrm{ft} / \mathrm{yr}$ at the eastern end. All wells show minor fluctuations in their water level trends that appear to be in response to KAFB pumping.

Former KAFB Lagoon - Water levels were measured during 1997 at three monitor wells at the site of the former KAFB sewage lagoons. Several KAFB water supply wells are located in this area and pumping affected several monitor wells, which showed fairly steep declines in water levels between the months of June and October. This is consistent with decline patterns in previous years. Wells KAFB-0502 and KAFB-0503 decline rates averaged $2.25 \mathrm{ft} / \mathrm{yr}$. This is slightly more than the overall decline rates in this area of $1.64 \mathrm{ft} / \mathrm{yr}$ between 1990 and 1997.

\subsubsection{Water Level Trends East of the Tijeras Fault Complex}

Wells located east of the Tijeras fault complex represent a variety of hydrogeologic conditions. The magnitude of water level changes over the period of 1 year is generally not more than 0.3 $\mathrm{ft}$. Fluctuations of water levels are assumed to be in response to seasonal groundwater recharge at the mountain front.

\section{Locations Near Fault Boundaries}

Wells located along the South Fence Road (SFR) were installed to assess the effects that the faults have on groundwater flow. Six SFR wells were measured in 1997. Water levels within this aquifer were fairly stable with an average increase of $0.22 \mathrm{ft} / \mathrm{yr}$ with the exception of SFR-1S. This well, unlike the others, had a decrease in water level elevation.

The groundwater level in SFR-3P, screened in bedrock, is about $80 \mathrm{ft}$ higher than in the SFR$3 \mathrm{~T}$ wells that are screened within the Santa Fe Group. Water levels in this well increased $1.4 \mathrm{ft}$ in 1997 while SFR-4T, which is also screened in fractured bedrock $1 / 4$ mile east of the SFR-3 wells, increased $3.8 \mathrm{ft}$ in 1997.

Other monitor wells, measured during 1997 in the vicinity of the fault boundaries, showed similar patterns of water level increases and declines. The 2-year decline rates for wells STW-1 and TRE-1 are 1.08 and $0.28 \mathrm{ft} / \mathrm{yr}$, respectively.

\subsection{POTENTIOMETRIC SURFACE}

A potentiometric surface map (Figure 7-4) was constructed using December 1997 static water level measurements from SNL/NM, KAFB, and COA monitoring wells. Most of the wells used are screened in the upper unit of the Santa Fe Group. The map represents the top surface of the water table of the regional aquifer system showing the horizontal groundwater gradients. (Groundwater flow is perpendicular to equipotential contours.) While many of the water levels represent an unconfined aquifer, the water levels measured in some of the wells indicate semi-confined or confined aquifers.

\subsubsection{West of the Tijeras Fault Complex}

Within the upper unit of the Santa Fe Group aquifer system, west of the Tijeras fault complex, the apparent horizontal direction of groundwater flow is west and northwest. This is in contrast to the southwesterly direction 


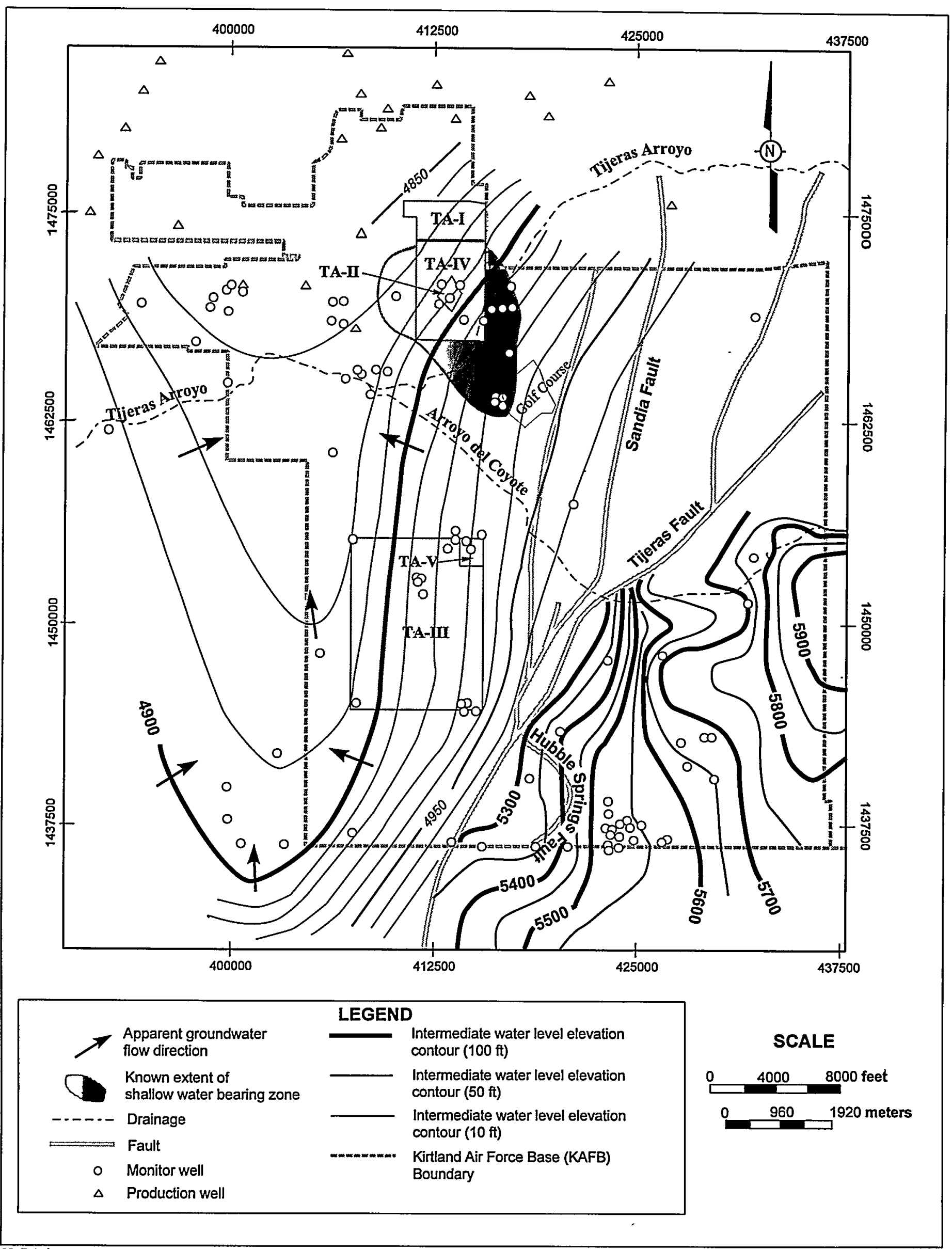


reported by Bjorklund and Maxwell (1961). This change in flow direction is a result of groundwater pumping in excess of recharge by KAFB and nearby COA water supply wells. Pumping from these well fields has created a groundwater depression along the western and northern boundaries of KAFB. The ellipsoidal shape of this depression, extending as far south as the Isleta Pueblo, is probably a result of preferential flow through highly conductive ancestral Rio Grande deposits that are the primary aquifer material in this area. Potentiometric contours on the northern portion of KAFB indicate a primarily northern flow direction. Locally, pumping from water supply wells can change the groundwater flow direction and the hydraulic gradient on a seasonal basis.

\subsubsection{East of the Tijeras Fault Complex}

Groundwater is more than $400 \mathrm{ft}$ higher east of the Tijeras fault zone than in the basin. East of the fault complex, groundwater flow direction and hydraulic gradient are controlled by topography and aquifer lithology. The hydraulic gradients are higher within saturated fractured bedrock than in more conductive alluvial fan deposit aquifers. Groundwater in this area generally flows southwest through Lurance Canyon. The potentiometric contours then parallel the fault zone with the inferred flow to the west, perpendicular to the fault zone.

\subsubsection{Shallow Water-Bearing Zones}

The lateral extent of the shallow groundwater zone is currently under investigation. The horizontal direction of groundwater flow in this zone at the Tijeras Arroyo Golf Course area appears to be to the south-southeast. The hydraulic gradient appears to be about 0.008 foot per foot.

\subsubsection{Groundwater Withdrawal}

SNL/NM's impact on the quantity of water in the groundwater system can only be determined indirectly. Water used for SNL/NM operations is provided by wells owned and operated by $\mathrm{KAFB}$. In addition, KAFB purchases some of its water from the COA. The distribution system on KAFB is interconnected and no provisions are made to meter SNL/NM water use. Currently, studies are underway to determine SNL/NM water use and to provide future metering capability.

During 1997, KAFB pumped approximately $916,111,000$ gal of groundwater from water supply wells located in the northern portion of KAFB. These wells are screened over a long interval (from about $500 \mathrm{ft}$ to $1,000 \mathrm{ft}$ below the ground surface). Both KAFB and COA wells are screened in the upper unit of the Santa $\mathrm{Fe}$ Group. The highest level of production from KAFB wells was in July $(112,923,000$ gal); the lowest was in November $(28,357,000 \mathrm{gal})$.

The effects of pumping from a production well can often be observed by water level changes in one or more nearby monitoring wells. SNL/NM facilities that are within the radius of influence of production wells may observe significant changes in water levels in their monitor wells, in relation to the activity of the nearby water supply well(s).

Many of the COA water supply wells are located near the northern boundary of KAFB. The wells in this field pump considerably more water than the KAFB wells. Their proportional contribution on fluctuations in groundwater levels at KAFB has not been evaluated. 


\subsection{GROUNDWATER QUALITY}

This section summarizes the analytical results for groundwater water quality monitoring activities conducted by the Groundwater Surveillance Task and the ER Project. Due to the volume of data obtained from the analyses conducted at each location, only results that exceeded one or more of the standards or guidelines referenced in table 7-2 are presented. Appendix A gives specific values for water quality standards. The sampling frequency performed under each task during 1997 is listed in table 7-3. All Groundwater results are detailed in the Groundwater Protection Program (CY97) Annual Groundwater Monitoring Report for SNL/NM (SNL 1998q).
TABLE 7-2. Guidelines Used for Groundwater Quality Sample Comparisons

\begin{tabular}{|l|c|}
\hline Regulation/Requirements & Limits \\
\hline $\begin{array}{l}\text { National Primary Drinking Water } \\
\text { Standards (this is an enforceable health } \\
\text { standard) (40 CFR 141) }\end{array}$ & MCL \\
\hline $\begin{array}{l}\text { New Mexico Water Quality Control } \\
\text { Commission Standards for } \\
\text { Groundwater }\end{array}$ & MAC \\
\hline $\begin{array}{l}\text { DOE Drinking Water Guidelines for } \\
\text { Radioisotopes (DOE 1993a) }\end{array}$ & DCG \\
\hline
\end{tabular}

NOTE: $\mathrm{MCL}=$ maximum contaminant level $\mathrm{MAC}=$ maximum allowable concentration $\mathrm{DCG}=$ derived concentration guide

TABLE 7-3. Sampling Frequency for Groundwater Quality Monitoring at SNL/NM During 1997

\begin{tabular}{|c|c|c|c|c|c|c|}
\hline $\begin{array}{c}\text { Sampling } \\
\text { Period }\end{array}$ & $\begin{array}{l}\text { Groundwater } \\
\text { Protection }\end{array}$ & \multicolumn{5}{|c|}{ ER Project Wells } \\
\hline & & CWL & MWL & TA-V & Sandia North & Canyons Area \\
\hline$\overline{\text { Dec } 96}$ & & & & $\checkmark$ & $\checkmark$ & \\
\hline Jan 97 & & & & & & \\
\hline Feb & & $\checkmark$ (annual) & & & & \\
\hline Mar & $\checkmark$ & & & $\checkmark$ & $\checkmark$ & \\
\hline$\overline{\text { Apr }}$ & & & $\bar{\checkmark}$ & & & \\
\hline May & & $\checkmark$ & & & & \\
\hline Jun & & & & $\checkmark$ & $\checkmark$ & \\
\hline Jul & & & & & & \\
\hline Aug & & $\checkmark$ & & & & \\
\hline Sep & & & & $\checkmark$ & $\checkmark$ & $\sqrt{ } *$ \\
\hline Oct & & & $\checkmark$ & & & \\
\hline Nov & & $\sqrt{*}$ & & & & \\
\hline Dec & & & & & $\sqrt{ } *$ & \\
\hline
\end{tabular}

NOTE: *Results from late year sampling were not available in time to be included in the Annual Groundwater Monitoring Report (CY97). 


\subsubsection{Groundwater Surveillance Task Water Quality Results}

The Groundwater Surveillance Task collects groundwater samples on an annual basis. The yearly sampling event occurred during March and April at nine monitoring wells and one spring. Water samples were analyzed for volatile organic compounds (VOCs), various metals, non-metallic inorganic substances (including nitrates, major ions, total organic carbon [TOC] and phenolics), selected radioisotopes (radium-226 and -228 , uranium$238,-235$, and -235 ), and total alpha and beta emissions.

Groundwater quality results are compared with the State of New Mexico's maximum allowable concentrations (MACs) for nonradioactive analytes. DOE's derived concentration guides (DCGs) are used as a measure of comparison for radioisotopes.

Trace concentrations of toluene, benzene, and chloroform were detected in three wells; however, all concentrations were significantly below the MCLs established for drinking water. The source of the trace VOCs is not clear. Trace amounts of toluene were found in the trip blanks prepared by the analytical laboratory.

The groundwater surveillance conducted by the SNL/NM GWPP indicated no significant impacts to groundwater water quality as a result of current SNL/NM activities.

\section{Metals}

Analyses were performed on all the samples for the following metals:

$\begin{array}{ll}\text { Aluminum (Al) } & \text { Arsenic (As) } \\ \text { Antimony (Sb) } & \text { Boron (B) } \\ \text { Beryllium (Be) } & \text { Barium (Ba) } \\ \text { Cadmium (Cd) } & \text { Calcium (Ca) } \\ \text { Cobalt (Co) } & \text { Copper (Cu) } \\ \text { Chromium (Cr) } & \text { Iron (Fe) } \\ \text { Lead (Pb) } & \text { Mercury (Hg) } \\ \text { Manganese (Mn) } & \text { Magnesium (Mg) } \\ \text { Nickle (Ni) } & \text { Potassium (K) }\end{array}$

$\begin{array}{ll}\text { Silver (Ag) } & \text { Selenium (Se) } \\ \text { Sodium (Na) } & \text { Thallium (Tl) } \\ \text { Vanadium (V) } & \text { Zinc (Zn) }\end{array}$

The analyses were conducted on the filtered samples except for mercury, which was analyzed for the total concentration. Beryllium and nickel concentrations in excess of MCLs were reported for Coyote Springs and SFR-3P, respectively. Elevated nickel concentrations in wells are often the result of corrosion of stainless steel well screens.

\begin{tabular}{|l|l|l|}
\hline \multicolumn{3}{|c|}{ Metals } \\
\hline \multicolumn{1}{|c|}{ Well } & \multicolumn{1}{|c|}{$\begin{array}{c}\text { Concentration } \\
(\mathrm{mg} / \mathrm{l})\end{array}$} & $\begin{array}{c}\text { Period } \\
(\mathbf{1 9 9 7})\end{array}$ \\
\hline Beryllium $M C L=0.004 \mathrm{mg} / \mathrm{l}$ \\
\hline Coyote Springs & 0.0067 & Mar/Apr \\
\hline Nickel $M C L=0.01 \mathrm{mg} / \mathrm{l}$ & Mar/Apr \\
\hline SFR-3P & 0.35 & Mar/Apr \\
\hline Iron $M C L=0.3 \mathrm{mg} / \mathrm{l}$ & Mar/Apr \\
\hline Schoolhouse & 0.8 & Mar/Apr \\
\hline SFR-2S & 0.36 & \\
\hline Greystone & 24.7 & Mar/Apr \\
\hline Thallium $M C L=0.002 \mathrm{mg} / \mathrm{l}$ & \\
\hline Greystone & 0.0039 & \\
\hline
\end{tabular}

\section{Volatile Organic Carbons (VOCs)}

Groundwater samples were analyzed for VOCs using EPA's Method 8010 and 8020. Trace concentrations of toluene, benzene, and chloroform were detected in three wells; however, all concentrations were significantly below the MCLs established for drinking water. The source of the trace VOCs is not clear. Trace amounts of toluene were found in the trip blanks prepared by the analytical laboratory.

Major Ions, Phenolics, and Total Organic Carbon (TOC)

Non-metallic inorganic constituents analyzed in groundwater samples included: 


Alkalinity
Bromide
Chloride
Cyanide (total)
Fluoride
Nitrate plus nitrite (as nitrogen)
Phenolics (total)
Sulfate
Total organic carbon (TOC)

There were no exceedences of any of these nonorganic parameters during 1997.

\section{Gamma-Emitting Radionuclide Screen Analyses}

Gamma spectroscopy was performed with a high-purity germanium gamma spectroscopy system on all samples. Potassium 40, lead 214, radium 226 and 228, and actinium 228 were detected with activities greater than the associated minimum detectable activity (MDA) in some groundwater samples. Analysis results are compared to the EPA MCLs and DOE guidelines. It should be noted that there is a high degree of measurement uncertainty in the activities reported.

Potassium-40 was over the DOE guideline in four wells. The DOE guideline is $280 \mathrm{pCi} /$; the highest value was $547 \pm 194 \mathrm{pCi} / \mathrm{l}$ reported at the TRE-1 well.

Radium-226 was reported in the sample from SFR-2S at an activity exceeding the MCL (5 $\mathrm{pCi} / \mathrm{l})$ and the $\mathrm{DOE}$ guideline $(25 \mathrm{pCi} / \mathrm{l})$. However, radium-226 is primarily an alpha emitter that has a low gamma yield. (The MDA for radium using the gamma method is 277 $\mathrm{pCi} / \mathrm{l}$.) Therefore, the gamma screen analysis is less accurate than the radioisotope analysis performed using alpha spectroscopy. Based on the results of the radioisotopic analysis, it does not appear that the radium-226 activities exceed the MCL and the DOE guideline.

Radium-228 also appeared to exceed the same standards in samples from TRE-1. Similarly, in comparing the results obtained by gamma spectroscopy for radium-228 to the isotopic analysis for the same sample, the radium-228 activity level is below the MCL and the DOE Guideline.

Of the radionuclides detected by gamma spectroscopy, radium-226 and lead-214 are members of the naturally-occurring uranium decay series; radium-228 is a member of the naturally occurring thorium decay series. Actinium-228 is a decay product of radium-228. Potassium-40 is a naturally-occurring radionuclide.

\section{Radiochemistry}

Radiochemical analyses were conducted on samples for gross alpha, gross beta, radium-226, radium-228, and uranium-234, -236 , and -238 .

Results of these analyses are compared to the DCGs and the MCLs. The MCL and DCG are based on the gross alpha activity after subtracting uranium and radon activity. (Isotopic radon activity was not determined.)

Gross alpha activity exceeded the numerical value for the MCL at SFR-2S, SFR-3P, and TRE-1. The EPA MCL and the DOE guideline limit are based on the gross alpha activity after subtracting uranium and radon activity. After adjusting the gross alpha number by subtracting the uranium activities, only the sample from the SFR-2S well exceeded the MCL and DOE guideline for gross alpha activity. No analysis was conducted for naturally-occurring thorium232 and its decay products.

\begin{tabular}{|c|c|c|c|}
\hline MCL $=15 \mathrm{pCi} / 1$ \\
\hline Well & $\begin{array}{c}\text { Concen- } \\
\text { tration } \\
\text { (pCi//) }\end{array}$ & $\begin{array}{c}\alpha-\mathrm{U}^{*} \\
(\mathrm{pCi} / \text { ) }\end{array}$ & $\begin{array}{c}\text { Period } \\
(1997)\end{array}$ \\
\hline SFR-2S & 48.3 & 22.7 & $\mathrm{Mar} / \mathrm{Apr}$ \\
\hline SFR-3P & 30.2 & 4.9 & $\mathrm{Mar} / \mathrm{Apr}$ \\
\hline TRE-1 & 30.7 & 0 & $\mathrm{Mar} / \mathrm{Apr}$ \\
\hline
\end{tabular}
$\begin{aligned} & \text { NOTE: *The total after uranium activity is subtracted } \\
& \text { from gross alpha activity. }\end{aligned}$

Uranium isotope activities were consistent with naturally-occurring uranium isotopic ratios in 
groundwater for all samples. The isotopic ratio for uranium isotopes in groundwater are not the same as those expected for soil or rock due to isotope specific physical processes that partition the isotopes between soil or rock and groundwater matrices. In converting the activities of uranium isotopes to concentration values using the specific activities for each isotope, the resulting concentration for uranium at SFR-2S is $0.0251 \mathrm{mg} / \mathrm{l}$. This is well below the maximum allowable concentration (MAC) of $5.0 \mathrm{mg} / \mathrm{l}$ established by the NMWQCC.

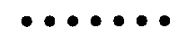

\subsubsection{ER Project Water Quality Results}

ER water quality sampling occurred at wells located at the Chemical Waste Landfill (CWL), Mixed Waste Landfill (MWL), TA-V, Sandia North, and the Canyons Test Area.

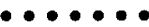

\section{Chemical Waste Landfill}

The ER Project performed annual groundwater sampling at the CWL in February 1997. Quarterly monitoring was conducted in May, August, and November 1997. November results were not ready in time for inclusion into the annual groundwater report (SNL 1998q). Groundwater samples were collected from 12 wells including two up-gradient wells for background water quality determination. The samples were analyzed for VOCs and RCRA metals, listed in Appendix IX of 40 CFR Part 264. Analytes and the frequency of sampling are specified in Appendix $G$ of the closure plan (SNL 1992a).

\section{Volatile Organic Compounds (VOCs)}

All VOCs detected were at concentrations below the EPA's established MCL, where applicable, except for trichloroethene (TCE). TCE concentrations in excess of the MCL of $5 \mu \mathrm{g} / 1$ were detected in four wells during the annual sampling in February and the quarterly sampling in May. The highest value was $21 \mu \mathrm{g} / \mathrm{l}$ February.

\begin{tabular}{|c|c|l|}
\hline \multicolumn{3}{|c|}{ TCE } \\
\hline MCL $=5 \mu \mathrm{g} / 1$ & $\begin{array}{c}\text { Concentration } \\
(\mu \mathrm{g} /)\end{array}$ & $\begin{array}{c}\text { Period } \\
(\mathbf{1 9 9 7})\end{array}$ \\
\hline Well & 5.5 & Feb \\
\hline CWL-MW1A & 18 & Feb \\
CWL-MW2A & 21 & Feb \\
“W" " & 7.65 & May \\
\hline CWL-MW2BU & 15 & Feb \\
" " & 7.68 & May \\
\hline CWL-MW5L & 7.2 & Feb \\
\hline
\end{tabular}

Additional VOCs detected at or above laboratory quantitation limits include:

Acetone

1,1-dichloroethene

Methylene chloride

1,1,1-trichloroethane

Tetrachloroethene

Trichlorofluoromethane

Vinyl acetate

All of these VOCs were present at concentration below the established MCL, where applicable. Their presence is considered to be a result of laboratory contamination and not an indication of groundwater contamination.

\section{Metals}

All groundwater samples collected from CWL monitoring wells during 1997 were analyzed for 40 CFR 264 Appendix IX metals plus iron.

Nickel was detected at concentrations above the MCL of $0.1 \mathrm{mg} / 1$ in groundwater samples from five CWL monitor wells during all three sampling periods. The highest was $2.71 \mathrm{mg} / \mathrm{l}$ in August. Elevated nickel is likely to be the result of stainless steel well screen corrosion. 


\begin{tabular}{|c|c|c|}
\hline \multicolumn{3}{|c|}{ Nickel } \\
\hline Well & $\begin{array}{c}\text { Concentration } \\
\text { (mg/l) }\end{array}$ & $\begin{array}{l}\text { Period } \\
\text { (1997) }\end{array}$ \\
\hline CWL-MW2A & 0.250 & Feb \\
\hline 64 & 0.548 & May \\
\hline $\begin{array}{l}\text { CWL-MW2A } \\
\text { (split) }\end{array}$ & 0.690 & Feb \\
\hline CWL-BW3 & 0.504 & May \\
\hline$"$ & 0.259 & Aug \\
\hline CWL-MW1A & 0.30 & May \\
\hline $\begin{array}{l}\text { CWL-MW3A } \\
\text { duplicate }\end{array}$ & 0.126 & May \\
\hline CWL-MW3A & 0.123 & May \\
\hline CWL-MW4 & 1.86 & May \\
\hline " & 2.71 & Aug \\
\hline $\begin{array}{l}\text { CWL-MW4 } \\
\text { duplicate }\end{array}$ & 2.04 & Aug \\
\hline
\end{tabular}

Antimony was detected above the MCL in two wells during the August sampling. (Preliminary results from the November sampling indicate antimony was not above the MCL.)

\begin{tabular}{|c|c|c|}
\hline \multicolumn{3}{|c|}{ Antimony } \\
MCL $=0.006 \mathrm{mg} / \mathrm{l}$
\end{tabular}

Thallium was detected at the MCL of $0.002 \mathrm{mg} / \mathrm{l}$ in the groundwater split sample collected from CWL-MW4 in February.

Additional parameters analyzed included semivolatile organic compounds (SVOCs), chlorinated pesticides, polychlorinated biphenyls (PCBs), herbicides, dioxins and furans, total cyanide, and total sulfide. None of these other water quality indicators analyzed during 1997 were detected above laboratory quantitation limits.

\section{Mixed Waste Landfill}

The ER project performed groundwater sampling at all five MWL monitoring wells in April and October 1997. The October data were not available for inclusion in the annual groundwater report (SNL 1998q). Samples were analyzed for VOCs, 40 CFR 264 Appendix IX metals, nitrates, and radionuclides.

\section{Volatile Organic Compounds (VOCs)}

VOCs were not detected above established MCLs, where applicable, for any samples collected during the April 1997 sampling event. Acetone, a common laboratory contaminant, was detected at a concentration of $11 \mathrm{ug} / \mathrm{l}$ in the duplicate groundwater sample from MWLMW4. No MCL has been established for acetone. Toluene, also a laboratory contaminant, was detected below the laboratory practical quantitation limit (PQL) in groundwater samples from MWL-BW1 and MWL-MW2.

\section{Nitrates}

No nitrates above MCL were detected in groundwater at the MWL.

\section{Metals}

Chromium was detected above the MCL in the sample collected from MWL-MW1 as shown below. Grbundwater samples collected from this well were observed to have high turbidity levels during sampling. No other RCRA metals were detected in concentrations that exceeded the EPA MCLs or above background levels.

\begin{tabular}{|c|c|c|}
\hline \multicolumn{3}{|c|}{ Chromium } \\
\hline MCL $=0.1 \mathrm{mg} / \mathrm{l}$ & $\begin{array}{c}\text { Concentration } \\
\text { (mg/l) }\end{array}$ & $\begin{array}{c}\text { Period } \\
(1997)\end{array}$ \\
\hline MWL-MW1 & 1.1 & Apr \\
\hline
\end{tabular}

\section{Radionuclides}

The radiochemical analyses included gross alpha, gross beta, tritium, and strontium- 90 . 
Radionuclide activities did not exceed the DOE guidelines and are comparable with previous years' results.

\section{$\cdots \cdots \cdots$}

\section{Technical Area $V$}

The ER Project performed quarterly groundwater sampling at TA-V in March, June, and September 1997. Samples were collected from six wells including at the Liquid Waste Disposal System (LWDS), which was joined to the TA-V investigational unit for operational purposes. The results for December 1996 are also included in this year's report since the data were not available in time for inclusion in last year's report.

Quarterly samples were analyzed for VOCs and nitrate plus nitrite. In addition, the June samples were analyzed for a full suite of analytes that included VOCs, nitrate plus nitrite, SVOCs, RCRA metals plus beryllium, major anions and cations, tritium, gross alpha and beta, and gamma spectroscopy.

\section{Volatile Organic Compounds (VOCs)}

VOCs or SVOCs were not detected in any TA-V wells at concentrations exceeding the EPA's MCLs with the exception of TCE.

TCE contamination in low levels persist in TA$V$ groundwater; TCE only exceeded the MCL in LWDS-MW1, as shown in the table below.

Cis-1,2-dichloroethene (1,2-DCE), a degradation product of TCE, was also detected in monitoring well LWDS-MW1. No other organic compounds (VOCs or SVOCs) were detected above quantitation limits in any TA-V monitoring wells, except for the laboratory contaminants methylene chloride and acetone.

\begin{tabular}{|l|c|l|}
\hline \multicolumn{3}{|c|}{ TCE } \\
MAC $=100 \mu \mathrm{g} / 1$ \\
$\mathrm{MCL}=5.0 \mu \mathrm{g} / 1$
\end{tabular}

\section{Nitrates}

Nitrate concentrations in two wells equaled or slightly exceeded the EPA's primary drinking water MCL of $10.0 \mathrm{mg} / \mathrm{l}$. Nitrate concentrations in LWDS-MW1 ranged up to $11.3 \mathrm{mg} / \mathrm{l}$ in a split sample, while concentrations in AVN-1 ranged up to $10 \mathrm{mg} / \mathrm{l}$. Nitrate concentrations in these wells are consistent with prior years analytical results.

\begin{tabular}{|l|c|l|}
\hline \multicolumn{3}{|l|}{ Nitrate } \\
\hline Wel $=10.0 \mathrm{mg} / 1$ & $\begin{array}{c}\text { Concentration } \\
\text { (mg/) }\end{array}$ & $\begin{array}{l}\text { Period } \\
\mathbf{1 9 9 7}\end{array}$ \\
\hline LWDS-MW1 (split) & 11.3 & Mar \\
\hline $\begin{array}{l}\text { LWDS-MW1 } \\
\text { (duplicate) }\end{array}$ & 11.0 & May \\
\hline
\end{tabular}

\section{Metals}

No RCRA metals were detected in any TA-V well in concentrations that exceeded EPA's MCLs.

\section{Radionuclides}

Radionuclide analyses results showed no analytes detected in concentrations that exceeded EPA's MCLs or DOE's drinking water guidelines in any TA-V wells. 


\section{Sandia North}

The ER Project performed quarterly groundwater sampling at the Sandia North area in March, June, September, and December 1997. December data are not available for inclusion in this year's report. December 1996 data are included. Samples were collected from six shallow water-bearing zone wells and three regional aquifer wells in 1997.

December 1996 and March 1997 samples were analyzed for VOCs and nitrates only. A full suite of analytes including VOCs, SVOCs, RCRA metals, nitrates, major anions, gamma spectroscopy, gross alpha and beta, tritium, and uranium isotopes were analyzed in June, September, and December 1997.

\section{Volatile Organic Compounds (VOCs)}

TCE concentrations are unchanged from the 1996 results. Only WYO-1 and WYO-2 wells had TCE values above the EPA MCL. The TCE values ranged from a high of $6 \mu \mathrm{g} / 1$ in WYO-1 to a high of $6.6 \mu \mathrm{g} / 1$ in WYO-2 as shown below over the four reporting periods. SVOCs were non-detect for all regional and shallow waterbearing zone groundwater samples.

\begin{tabular}{|c|c|l|}
\hline \multicolumn{3}{|l|}{ TCE } \\
MCL $=5 \cdot \mu \mathrm{g} / \mathrm{l}$ \\
MAC $=100 \mathrm{mg} / \mathrm{l}$ \\
\hline Well & $\begin{array}{c}\text { Concentration } \\
(\mu \mathrm{g} / \mathrm{l})\end{array}$ & \multicolumn{1}{c|}{$\begin{array}{c}\text { Period } \\
(1997)\end{array}$} \\
\hline WYO-1 & $5.0(6.5)$ & Mar \\
& $5.6(8.6)$ & Jun \\
\hline WYO-2 & $6.0(7.5)$ & Mar \\
& 6.6 & Jun \\
& $5.6(9.0)$ & Sep \\
\hline
\end{tabular}

NOTE: The number in parentheses represents the results from an offsite confirmatory analysis.

\section{Nitrates}

Nitrate was consistently detected in TA2-SW1320 above the NMED maximum allowable concentration (MCL) of $10 \mathrm{mg} / \mathrm{l}$ with values ranging from 21 to $28 \mathrm{mg} / \mathrm{l}$ over three sampling periods. TA2-W-01 had one nitrate value exceeding the MCL in June as shown below. All other samples contained nitrate below the MCL.

\begin{tabular}{|l|c|l|}
\hline \multicolumn{3}{|c|}{ Nitrates } \\
\hline Well $=10 \mathrm{mg} / \mathrm{l}$ & $\begin{array}{c}\text { Concentration } \\
\text { (mg/) }\end{array}$ & Period \\
\hline TA2-SW1-320 & 26 & Dec 96 \\
& 28 & Mar 97 \\
& 21 & Jun 97 \\
\hline TA2-W-01 & 11.6 & Jun 97 \\
\hline
\end{tabular}

\section{Metals}

RCRA metals as listed below were not detected above the EPA MCL for any of Sandia North's wells. 


\section{Quality Assurance}

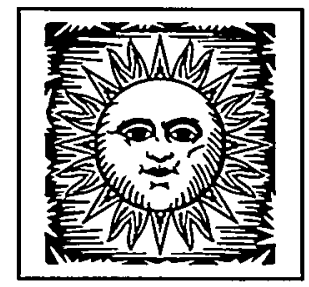

NL/NM is committed to providing quality work for sampling and analysis 1 procedures to ensure the validity and accuracy of all monitoring data. Environmental samples are collected at SNL/NM to support compliance as well as to follow specific DOE orders and SNL Best Management Practices. The following activities directly support regulatory compliance:

- Wastewater sampling at outfall stations to meet permit requirements of the City of Albuquerque (COA)

- Storm water runoff sampling to meet U.S. Environmental Protection Agency (EPA) requirements

- Environmental Restoration (ER) site sampling to meet Resource Conservation and Recovery Act (RCRA) permit requirements

- Waste sample characterization for hazardous and radioactive waste to meet Department of Transportation (DOT) and other requirements

Other sampling meets DOE objectives and supports compliance activities:

- Terrestrial surveillance monitoring of surface water, sediment, soil, and biological samples

- Groundwater quality sampling for site-wide surveillance

- Ambient air analyses for comparison with air quality standards
- Air emission sampling to support modeling input parameters

Samples from all program areas may be tested for both radiological and nonradiological analyses.

Sample and data management is handled by the Sample Management Office (SMO). The SMO provides sample tracking and collecting guidelines to ensure consistent quality of analysis results.

\subsection{ENVIRONMENTAL PROGRAM QUALITY ASSURANCE}

Environmental program areas have developed program documents (PG) that provide a highlevel overview of:

- Program goals outlining the required scope of work;

- Objectives describing how goals will be met;

- Process description of how objectives are accomplished; and

- Roles and responsibilities that identify who will meet program objectives (for example, requirement source documents, and SNL/NM implementing documents).

These PG documents are supplemented, as necessary, by Quality Assurance Project Plans (QAPjPs), specific procedures, and other 
supporting documents. Each program area develops its plans and procedures consistent with appropriate standards and level of quality assurance (QA) rigor for the respective environmental program. The hierarchy of $P G$ documents, QA plans, and procedures helps ensure that potential problems will be prevented. Specifically, program participants must adhere to the QA protocol within each program area. The following criteria must be met before activities commence:

- The applicable requirements are defined in the program-specific documents (such as plans and procedures).

- Personnel understand the requirements through familiarization and training.

- Qualification of personnel has been verified through task leaders and/or management. Self assessments of Environment, Safety, and Health (ES\&H) programs are performed. Assessments are also performed by the internal independent assessment organizations. Each ES\&H Center $\mathrm{SNL} / \mathrm{NM}$ employee and contractor is responsible for ensuring that all environmentally-related activities are performed according to applicable policies and practices set forth in these documents.

\section{ENVIRONMENTAL SAMPLING AND ANALYSIS}

Environmental sampling is conducted in accordance with program-specific sampling and analysis plans (SAPs) or work plans, each of which contain the applicable QA elements. These program-specific documents are prepared and implemented in accordance with the Sample Management Office (SMO) Quality Assurance Plan (QAP) (SNL 1996n) and meet appropriate regulatory guidelines (EPA, state, and local) for conducting sampling and analysis activities.

\section{SMO Roles and Responsibilities}

SMO provides guidance and support for field activities conducted by SNL/NM organizations. The overall adherence and compliance of any sampling and analysis activity, however, is the responsibility of each particular project.

Before field work commences, project leaders and SMO coordinators confer to ensure that the requirements of the sampling plan are established and communicated to the analytical laboratory. This step ensures that the data quality objectives (DQOs) (such as minimum detection levels) stated in the plan will be achievable by the laboratory before the project begins. An analysis request form and a chainof-custody form are filled out for each sample once the project begins. The SMO office assigns a unique control number with which the sample will be labeled and documented in the sample collection log. SMO is responsible for $\mathrm{QA}$ and quality control (QC) at the point of sample relinquishment by the field team into the custody of SMO staff. Information about the quantities and types of samples processed through the SMO are available in the SMO Sample Tracking Analytical Results (STAR) database.

\section{Project Specific Sample Analysis Plans (SAPs)}

Each program involved in environmental monitoring and sampling has developed or follows a relevant SAP. The specific elements present in most plans include the following:

- Descriptions of sampling procedures (mechanics of the process) applicable to each activity (such as describing the handling of samples, their preservation, labeling, and event documentation)

- A list of EPA-approved sample collection equipment, appropriate sample containers, and container decontamination procedures

- A schedule for the collection of QC samples at defined frequencies to estimate sample 
representativeness and potential contamination acquired during the sampling and handling process

\section{Selection of a Contract Laboratory}

All offsite contract laboratories are selected based on an appraisal (pre-award audit) as described in the SMO Quality Assurance Plan (SNL 1996n). All previous and candidate laboratories must employ EPA test procedures wherever possible; if not available, other suitable and validated test procedures are to be used. Laboratory instruments must be calibrated in accordance with established procedures and methods. All calibrations must be verified before instruments can be used in an analysis. Once a laboratory has passed the initial appraisal and has been awarded a contract, it is thereafter audited annually by the SMO. Technical and QA audits are coordinated by the SMO.

Contractor laboratories are required to participate in DOE and EPA programs for blindaudit check sampling to monitor the overall precision and accuracy of analyses routinely performed on SNL/NM samples.

\section{Quality Control (QC) Measures}

The QC process guarantees the quality of data generated by each analytical laboratory. Various field QC sample methods are used during the sample collection process to assess the quality of the data outcome. Errors that can be introduced into the sampling process include possible sample contamination in the field or the laboratory, some of which are unavoidable. Additionally, the variability present at each sample location can also affect results.

QC samples are submitted to contractor laboratories in accordance with project-specific DQOs and SAPs. Depending on the type of investigation, one or more of the following QC sampling measures may be performed:

- Replicate samples - Two environmental samples are collected from the same area and submitted to the laboratory to assess the overall variability of data associated with a particular sampling location.

- Split samples - A known homogeneous sample is divided and analyzed to compare precision of laboratory results.

- Field blank sampling - An unused (blank) sample is taken to measure conditions known to be present and associated with the field location-such as contributions which may be present from ambient air during soil sampling or from the filter or collection vessel itself. Blank samples assess the quality and unavoidable contamination present in the sampling process.

- Equipment blank sampling - Rinse water is collected off sampling equipment to determine what contaminants may be contributed from the field equipment itself.

- Trip blank sampling - A sample is prepared in the lab and carried through the entire sampling process (for example, a deionized water sample) to identify baseline volatile organic compound (VOC) contaminants that may be present from routine laboratory chemicals or other potential sources of contaminants.

- Double blind sampling - A sample with known concentrations of analytes is prepared and submitted to the laboratory to assess the precision and accuracy of the laboratory's stable chemistry analyses.

With each SNL/NM sample batch, QC samples are concurrently prepared at defined frequencies and analyzed for each constituent of interest to measure analytical accuracy, precision, contamination, and the matrix effect associated with each analytical measurement.

QC sample results are compared to statistically established control criteria. Analytical results generated concurrent with QC sample results are considered acceptable. If analytical results exceeded control limits, the results are not 
acceptable and corrective action is initiated. Reanalysis is then performed for all samples in the analytical batch.

QC sample data results are included in analytical reports prepared by subcontract laboratories for SNL/NM.

\subsection{7 swo actrutres}

In 1997 , the SMO processed a total of 7,470 samples in support of SNL/NM projects, which included environmental monitoring (air and water), waste characterization, demolition and decontamination (D\&D), and ER. Of the total samples handled, 3,220 were for environmental monitoring and surveillance projects. A total of 1,030 QC samples were submitted to monitor overall contract laboratory performance in 1997; 370 of these QC samples were for environmental monitoring and surveillance projects.

SMO contract laboratories participate in interlaboratory comparison programs of the EPA's Environmental Monitoring Systems Laboratory (EMSL) and the DOE Assessment Program. The SMO contract laboratories have a history of achieving a 90 percent or better success rate during these comparisons.

In 1997, QC double blind check samples consisted of soils containing trace metals, cyanides, and a variety of organic compounds. Double blind check samples were submitted quarterly. All check samples were prepared in batch quantities and subjected to "round-robin analyses." The Round-robin method allows several laboratories to perform analyses for selected parameters on the same sample batch. In this way, a statistical result can be calculated to verify analyte concentrations.
Results of each set of check sample analyses were documented in Quarterly Performance Evaluation Reports for each laboratory. Results included average percent recoveries for each suite of samples analyzed, the relative range of actual recoveries, and the relative percent differences for each analyte tested. Each laboratory was given a proficiency rating based on the results.

The resulting data were used to assess each contract laboratory's performance using relative percent difference and percent recovery for respective indicators of precision and accuracy. Review of laboratory performance data generated in 1997 indicated that the majority of analytes tested by the SNL/NM analytical laboratories were within EPA (or interlaboratory round-robin) prescribed control limits. All reports, including laboratory results and audit corrective action responses are filed within SMO.

\section{QA Audits}

SMO conducted audits of several of its contract laboratories. Using the centralized QA program criteria established by the Characterization Management Program of DOE/AL, SMO identified numerous concerns. All concerns have since been corrected or are near close out.

\section{Data Validation and Records Management}

Sample collection, control documentation, and measurement data were reviewed and validated for each sample collected. Analytical data reported by test laboratories were reviewed for laboratory and field precision, accuracy, completeness, representativeness, and comparability with respect to the data quality objectives (DQOs) of the particular program. Data were reviewed and validated at a minimum of three levels:

- By the analytical laboratory, where the data were validated in accordance with the laboratory's QA plan and standard operating procedures; 
- By a knowledgeable member of the SNL/NM SMO staff who reviewed the analytical reports and corresponding sample collection and control documentation for completeness and laboratory contract compliance; and
- By the SNL/NM project leader responsible for program objectives and regulatory compliance and the project-specific data quality requirements. 


\section{REFERENCES}

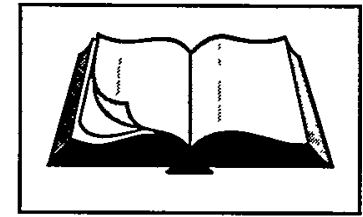

ACE

U.S. Army Corps of Engineers, Special Flood Hazard Information, Tijeras Arroyo

1979: and Arroyo del Coyote, Kirtland AFB, New Mexico. U.S. Army Corps of Engineers Albuquerque District, Albuquerque, NM (1979).

Bjorklund Bjorklund, L. J. and Maxwell, B. W., Availability of Groundwater in the Albuquerque Area, and Maxwell Bernalillo and Sandoval Counties, New Mexico. New Mexico State Engineer Technical 1961: $\quad$ Report 21, 117p. (1961).

CDM 1995: CDM Federal Programs Corporation, Oil Spill Prevention Control and Countermeasures (SPCC) Plan for Sandia National Laboratories, New Mexico, Plan 90-11. CDM Federal Programs Corporation, Albuquerque, NM (June 1995).

CRC 1992: Chemical Rubber Company, Trace Elements in Soils and Plants, 2nd. Ed. (authors: KabataPendias and Pendias). CRC Press, Inc., Boca Raton, Florida (1992).

DOC 1998: U.S. Department of Commerce, "U.S. Census Bureau Home Page," <www.census.gov/>, Washington, DC (1998).

DOE 1998a: U.S. Department of Energy, Accelerating Cleanup: Focus on 2006-Discussion Draft, DOE/EM0327. DOE Office of Environmental Management, Washington, DC (January 14, 1998).

DOE 1997a: U.S. Department of Energy, Environmental Assessment for the Atmospheric Radiation Measurement (ARM) Program North Slope of Alaska and Adjacent Arctic Ocean Cloud and Radiation Test Bed, DOE/EA-1193. DOE Kirtland Area Office, Albuquerque, NM (FONSI issued February 27, 1997) (1997).

DOE 1997b: $\quad$ U.S. Department of Energy, Environmental Assessment of the Sandia National Laboratories Design, Evaluation, and Test Technology Center at Technical Area III Kirtland Air Force Base, New Mexico, DOE/EA-1195. DOE Kirtland Area Office, Albuquerque, NM (FONSI issued April 18, 1997).

DOE 1997c: $\quad$ DOE Order 232.1a (See Orders Section).

DOE 1997d: $\quad$ DOE Order 451.1a (See Orders Section).

DOE 1996a: Sandia National Laboratories, Environmental Assessment of the ER Project at SNL/NM, DOE EA1140-SNA-EA93-01. DOE, Kirtland Area Office, Albuquerque, New Mexico (FONSI issued March 25, 1996).

DOE 1996b: U.S. Department of Energy, Work Book: Future Use Management Area 3, 4, 5, and 6. Future Use Logistics and Support Working Group, U.S. Department of Energy, Kirtland Area Office, Albuquerque, New Mexico (January 1996). 
DOE 1996c: U.S. Department of Energy, Work Book: Future Use Management Area 7. Future Use Logistics and Support Working Group, U.S. Department of Energy, Kirtland Area Office, Albuquerque, New Mexico (March 1996).

DOE 1996d: DOE Order 151.1 (See Orders Section).

DOE 1995a: U.S. Department of Energy, Work Book: Future Use Management Area 1. Future Use Logistics and Support Working Group, U.S. Department of Energy, Kirtland Area Office, Albuquerque, New Mexico (October 1995).

DOE 1995b: U.S. Department of Energy, Work Book: Future Use Management Area 2. Future Use Logistics and Support Working Group, U.S. Department of Energy, Kirtland Area Office, Albuquerque, New Mexico (September 1995).

DOE 1994a: U.S. Department of Energy, Secretary's Policy Statement on the National Environmental Policy Act. DOE, Washington, DC (June 1994).

DOE 1993a: DOE Order 5400.5 (See Orders Section).

DOE 1990a: DOE Order 5400.1 (See Orders Section).

DOE 1990b: U.S. Department of Energy, The Secretary of Energy; NEPA Notice (SEN-15-90). DOE, Washington, DC (February 5, 1990).

DOE 1988a: DOE Order 5820.2A (See Orders Section).

DOE 1987: U.S. Department of Energy/Albuquerque Operations Office (DOE/AL), Comprehensive Environmental Assessment and Response Program (CEARP) Phase 1: Installation Assessment, draft DOE/AL, Environment, Safety and Health Division, Albuquerque, NM (September 1987).

DOI 1998: U.S. Department of the Interior, United States Geographical Survey, "USGS Geographic Names Information System Online Database Query Form," < wwwnmd.usgs.gov/www/gnis/gnisform.html >, Washington, DC (1998).

EPA 1990: U.S. Environmental Protection Agency, "Obtaining a Soil and Debris Treatability Variation for Remedial Actions," in Superfund Land Disposal Restrictions (LDR) Guide 6A, 9347.3-06 FS, Second Edition. EPA, Washington DC.

EPA 1995: U.S. Environmental Protection Agency, CAP88, Clean Air Act Assessment Package, Radiation Shielding Information Center, CCC-542. EPA, Oak Ridge, TN (1995).

ERDA 1977: Energy Research \& Development Administration, Environmental Impact Assessment, Sandia Laboratories, Albuquerque, New Mexico, EIA/MA 77-1. Energy Research \& Development Administration, Division of Military Application (May 1977)

NOTE: ERDA was the predecessor to DOE. The EIA was written according to NEPA law of 1970. This predates the Council on Environmental Quality regulations 40 CFR 1500-1508, which stipulates the procedure for preparing an EA or EIS.

GRANT 1982: Grant, P.R., Jr., "Geothermal Potential in the Albuquerque Area, New Mexico," in GuidebookNew Mexico Geological Society, Volume 33, pp. 325-331 (1982). New Mexico Geological Society (1982). 
Hostak 1995: Hostak J.M, Characterization of Environmental Radiation and Radioactivity Near Albuquerque New Mexico, NMED/DOE/AIP-95/3. Sandia National Laboratories, Albuquerque, NM (1995).

IT 1996: IT Corporation, Background Concentrations of Constituents of Concern to the Sandia National Laboratories, New Mexico Environmental Restoration Program and the Kirtland Air Force Base Installation Restoration Program, IT Corporation (January 1996).

Kelley 1977: $\quad$ Kelley, V. C., Geology of Albuquerque Basin, New Mexico, Memoir 33. New Mexico Bureau of Mines and Mineral Resources, Socorro, NM (1977).

Kelley and Kelley, V. C., and S. A. Northrup, Geology of Sandia Mountains and Vicinity,

Northrup New Mexico, Memoir 29. New Mexico Bureau of Mines and Mineral Resources,

1975: $\quad$ Soccorro, NM (1975).

Lozinsky et Lozinsky, Richard P., and Teford, Geology and Paleontology of the Santa Fe Group, Southwest al. 1991: $\quad$ Albuquerque Basin, Valencia County, New Mexico. New Mexico Bureau of Mines and Mineral Resources, Institute of Mining and Technology, Socorro, NM (1991).

Machette et Machette, M., C. Wentworth, and J. Nakata, "Quaternary Fault Map of the Basin and Range and al. 1982: $\quad$ the Rio Grande Rift Provinces, Western United States," in Open File Report 82-579. U.S. Geological Survey, Denver CO (1982).

NMDOA 1998: State of New Mexico Department of Agriculture, "The New Mexico Department of Agriculture Home Page - 1995 Agricultural Statistics," <nmdaweb.nmsu.edu/ >, Las Cruces, NM (1998).

NMED 1995 New Mexico State Environment Department, Discharge Plan Modification and Renewal, DP-530, SNL/NM. New Mexico State Environment Department, Santa Fe, NM (February 24, 1995).

NMGS 1984: New Mexico Geological Society, Rio Grande Riff, Northern New Mexico. $35^{\text {th }}$ Annual Field Conference, October 11-13, 1984. Editors: W. Scott Baldridge, Patricia Dickerson, Robert Riecker, and Jiri Zidek. NMGS, Socorro, NM (October 1984).

NOAA 1994: U.S. Department of Commerce, "NOAA (National Oceanic and Atmospheric Administration) Environmental Data Service, monthly and annual distribution by Pasquill Stability Classes, STAR Program, Tonopah, NV," National Climatic Center (NCC) Federal Building, Ashville, NC (1993).

Radian 1994: Radian Corporation, Measurement of Tritium and Volatile Organic Compound (VOC) Fluxes from Mixed Waste Landfill at Sandia National Laboratories, New Mexico. Radian Corporation (May 24, 1994).

Shyr, Herrera, Shyr, L.J., H. Herrera, R. Haaker, The Role of Data Analysis in Sampling Design of Environmental Haaker 1998: Monitoring, SAND98-0612. Sandia National Laboratories, Albuquerque, NM (March 1998).

SNL 1998a: Sandia National Laboratories, Supporting Documentation for the Hazardous Chemical Purchase Inventory 1997 Reporting Year. Sandia National Laboratories, Albuquerque, NM (May 1998).

SNL 1998b: $\quad$ Sandia National Laboratories, (1) NESHAP Annual Report for CY 1997, (2) Radiological Dose Calculations and Supplemental Dose Assessment Data for NESHAP Compliance SNL/NM, 1997. Sandia National Laboratories, Albuquerque, NM (1998). 
SNL 1998c: $\quad$ Sandia National Laboratories, Mixed Waste Site Treatment Plan, Compliance Plan Volume (CPV) Background Volume, Revision 2. Sandia National Laboratories, Albuquerque, NM (January 1998).

SNL 1998d: Sandia National Laboratories, Section A - "Hazardous Waste Management," from Chapter 19, Waste Management, of the ES\&H Manual, MN471001, Issue H. Sandia National Laboratories, Albuquerque, NM (February 24, 1998).

SNL 1998e: Sandia National Laboratories, Section B— "Low-Level Radioactive Waste Management," from Chapter 19, Waste Management, of the ES\&H Manual, MN471001, Issue H. Sandia National Laboratories, Albuquerque, NM (February 24, 1998).

SNL 1998f: Sandia National Laboratories, Section C_-“Mixed Waste Management," from Chapter 19, Waste Management, of the ES\&H Manual, MN471001, Issue H. Sandia National Laboratories, Albuquerque, NM (February 24, 1998).

SNL 1998g: Sandia National Laboratories, Section D_-"Radioactive Material Management Areas (RMMAs)," ' from Chapter 19, Waste Management, of the ES\&H Manual, MN471001, Issue H. Sandia National Laboratories, Albuquerque, NM (February 24, 1998).

SNL 1998h: Sandia National Laboratories, Section E-“Chemical Spills" from Chapter 10, Environmental Protection, of the ES\&H Manual, MN471001, Issue F. Sandia National Laboratories, Albuquerque, NM (January 15, 1998).

SNL 1998i: Sandia National Laboratories, Section F-“Oils, Greases, and Fuels," from Chapter 10, Environmental Protection, of the ES\&H Manual, MN471001, Issue E. Sandia National Laboratories, Albuquerque, NM (June 10, 1997).

SNL 1998j: Sandia National Laboratories, Section H-_'Discharges to the Sanitary Sewer System" from Chapter 10, Environmental Protection, of the ES\&H Manual, MN471001, Issue Y. Sandia National Laboratories, Albuquerque, NM (January 15, 1998).

SNL 1998k: Sandia National Laboratories, Section K-“Underground Storage Tanks," from Chapter 10, Environmental Protection, of the ES\&H Manual, MN471001, Issue Y. Sandia National Laboratories, Albuquerque, NM (January 15, 1998).

SNL 19981: Sandia National Laboratories, Section T_- "Surface and Storm Water Discharges" from Chapter 10, Environmental Protection, of the ES\&H Manual, MN471001, Issue Y. Sandia National Laboratories, Albuquerque, NM (January 15, 1998).

SNL 1998m: Sandia National Laboratories, 1997 Environmental Surveillance Data Analysis Report. Sandia National Laboratories, Albuquerque, NM (unpublished) (1998).

SNL 1998n: Sandia National Laboratories, Ecological Monitoring for 1997: Small Mammals, Reptiles, Amphibians, Birds, and Vegetation, 75-1054. Sandia National Laboratories, Albuquerque, NM (1998).

SNL 19980: $\quad$ SNL/NM Summary Pamphlet, Calendar Year 1997, Summary of the Annual Site Environmental Report (ASER), SAND98-xxxx (in Final). Sandia National Laboratories, Albuquerque, NM (September 1998).

SNL 1998p: $\quad$ Sandia National Laboratories, Results of 1997 Storm Water Sampling. Sandia National Laboratories, Albuquerque, NM (1997). 
SNL 1998q: $\quad$ Sandia National Laboratories, Groundwater Protection Program (CY97) Annual Groundwater Monitoring Report for SNL/NM. Sandia National Laboratories, Albuquerque, NM (March 1998).

SNL 1997a: Sandia National Laboratories, Ozone Depleting Substances (ODS) Management Plan, AOP 97-04, Rev. 00. Sandia National Laboratories, Albuquerque, NM (January 9, 1997).

SNL 1997b: Sandia National Laboratories, Waste Management, PG 470185, Issue C. Sandia National Laboratories, Albuquerque, NM (, July 22, 1997).

SNL 1997c: Sandia National Laboratories, Pollution Prevention Plan. Sandia National Laboratories, Albuquerque, NM (May 1997).

SNL 1997d: Sandia National Laboratories, Environmental Monitoring and Surveillance Program, PG470103, Issue C. Sandia National Laboratories, Albuquerque, NM (November 1997).

SNL 1997e: $\quad$ Sandia National Laboratories, Radiological NESHAP Quality Assurance Project Plan (QAPjP), QAP98-01 Rev. 1. Sandia National Laboratories, Albuquerque, NM (June 16, 1997).

SNL 1997f: Sandia National Laboratories, Corporate Ozone-Depleting Substances-Management Program, PG470192, Issue B. November, Sandia National Laboratories, Albuquerque, NM (November 1997).

SNL 1997g: Sandia National Laboratories, Air Quality, PG470098, Issue C (November 1997).

SNL 1997h: Sandia National Laboratories, Inspection and Maintenance Plan for Guyed Structures, 75-1009. Sandia National Laboratories, Albuquerque, NM (1997).

SNL 1997i: $\quad$ Sandia National Laboratories, Quality Assurance Project Plan (QAPjP) Meteorological and Ambient Air Monitoring Program, QUA-94-03, Rev. 2. Sandia National Laboratories, Albuquerque, NM (February 14, 1997).

SNL 1997j: Sandia National Laboratories, "Section A-NEPA, Sensitive Species, and Historic Properties," from Chapter 13 of the ES\&H Manual, MN471001, Issue E. Sandia National Laboratories, Albuquerque, NM (August 28, 1997).

SNL 1997k: $\quad$ Sandia National Laboratories, Water Quality, PG 470187, Issue B. Sandia National Laboratories, Albuquerque, NM (November 1997).

SNL 1997l: Sandia National Laboratories, DP-530 Semi-Annual Report. Sandia National Laboratories, Albuquerque, NM (1997).

SNL 1996a: Sandia National Laboratories, SNL/NM Environmental Baseline Update, Rev 1.0 SAND96-1608. Sandia National Laboratories, Albuquerque, NM (July 1996).

SNL 1996b: Sandia National Laboratories, Environmental Restoration (ER) Site Atlas. SNL/NM ER Project, Sandia National Laboratories, Albuquerque, NM (1996).

SNL 1996c: Sandia National Laboratories, Programmatic Waste Acceptance Criteria, POL 95-01. Sandia National Laboratories, Albuquerque, NM (May 24, 1996).

SNL 1996d: Sandia National Laboratories, Medical Waste, PG470108, Issue B. Sandia National Laboratories, Albuquerque, NM (February 9, 1996). 
SNL 1996e: $\quad$ Sandia National Laboratories, Chemical Waste Management, PG 470105. Sandia National Laboratories, Albuquerque, NM (1996).

SNL 1996f: ～(place holder)

SNL 1996g: Sandia National Laboratories, Environmental Monitoring Plan, PLA 95-37, Rev. 0. Sandia National Laboratories, Albuquerque, NM (October 1996).

SNL 1996h: $\quad$ Sandia National Laboratories, Quality Assurance Project Plan (QAPjP) for Terrestrial Surveillance at SNL/NM, QUA 94-04, Rev 1. Sandia National Laboratories, Albuquerque, NM (July 31, 1996).

SNL 1996i:: $\quad$ Sandia National Laboratories, Environmental ALARA Program, PG 470194, Issue A. Sandia National Laboratories, Albuquerque, NM (July 9, 1996).

SNL 1996j: $\quad$ Sandia National Laboratories, Quality Assurance Project Plan (QAPjP) for Air Quality Compliance, QUA 94-05, Rev. 2. Sandia National Laboratories, Albuquerque, NM (July 10, 1996).

SNL 1996k: Sandia National Laboratories, SNL/NM Wastewater Sampling and Analysis Plan, Plan 92-06, Rev. 2. Sandia National Laboratories, Albuquerque, NM (June 1996).

SNL 19961: Sandia National Laboratories, Sampling and Analysis Plan (SAP) for the Pulsed Power Development Facilities, Building 981, 983, and 970 for Lagoons 1 and 2, PLA 94-48, Rev. 01. Sandia National Laboratories, Albuquerque, NM (May 24, 1996).

SNL 1996m: Sandia National Laboratories, Storm Water and Non-storm Water Discharge Sampling and Analysis Project Plan for SNL/NM, Plan 91-16, Rev. 3. Sandia National Laboratories, Albuquerque, NM (June 1996).

SNL 1996n: $\quad$ Sandia National Laboratories, Sample Management Office (SMO) Quality Assurance Plan (QAP), 95-01, Rev. 1. Sandia National Laboratories, Albuquerque, NM (January 1996).

SNL 1995a: Sandia National Laboratories, Program Implementation Plan for Albuquerque Potential Release Sites. SNL ER Program, U.S. Department of Energy, Albuquerque Operations Office, New Mexico (February 20, 1995).

SNL 1995b: Sandia National Laboratories, Site Treatment Plan for Mixed Waste, Sandia National Laboratories, New Mexico. Sandia National Laboratories, Albuquerque, NM (1995). (Enforced Oct. 6, 1995).

SNL 1995c: $\quad$ Sandia National Laboratories, $P C B$ Inventory and Waste Disposal Program, PG 470114, Issue B. Sandia National Laboratories ER Project, Albuquerque, NM (July 26, 1995).

SNL 1995d: Sandia National Laboratories, Chemicals Materials Storage Program, PG470189, Issue A (June 7, 1995).

SNL 1995e: $\quad$ Sandia National Laboratories, Asbestos Waste Operations Management Program, PG 470186, Issue A. Sandia National Laboratories, Albuquerque, NM (August 29, 1995). 
SNL 1995f: Sandia National Laboratories, Explosive Waste Program, PG470191, Issue A. Sandia National Laboratories, Albuquerque, NM (May 19, 1995).

SNL 1995g: Sandia National Laboratories, Solid Waste Program, PG470106, Issue B. Sandia National Laboratories, Albuquerque, NM (May, 8, 1995).

SNL 1995h: $\quad$ Sandia National Laboratories, Septic Tank Sampling Project Waste Management Plan, PLA 9539, Rev. 00. Sandia National Laboratories ER Project, Albuquerque, NM (August 10, 1995).

SNL 1993a: Sandia National Laboratories, Conceptual Site Treatment Plan for Mixed Waste. Sandia National Laboratories, Albuquerque, NM (October 1993).

SNL 1992a: Sandia National Laboratories, Chemical Waste Landfill Final Closure Plan and Postclosure Permit Application, Volume 2C. Appendices include the "Sampling and Analysis Plan (SAP) for Groundwater Assessment Monitoring at the Chemical Waste Landfill," Revision 4.0, Appendix G. Environmental Restoration Program, Sandia National Laboratories, Albuquerque, NM (1992) (Approved in May 1993).

SNL 1991a: Sandia National Laboratories, Radioactive and Mixed Waste, PG470104, Issue A. Sandia National Laboratories, Albuquerque, NM (March 28, 1991).

SNL 1991b: $\quad$ Sandia National Laboratories, National Environmental Policy Act (NEPA), PG470110, Issue A. Sandia National Laboratories, Albuquerque, NM (March 28, 1991).

SNL 1991c: $\quad$ Sandia National Laboratories, Facilities Asbestos Management, PG470107, Issue A. Sandia National Laboratories, Albuquerque, NM (March 28, 1991).

SNL 1991d: $\quad$ Sandia National Laboratories, Pollution Prevention, PG470112, Issue A. Sandia National Laboratories, Albuquerque, NM (March 28, 1991).

Thorne 1993: Thorn, C.R., P. McAda, and J.M. Kernodle, Geohydrologic Framework Hydrologic Conditions in the Albuquerque Basin, Central New Mexico, Water Resources Investigation Report 93-4149. U.S. Geological Survey, Albuquerque, NM (1993).

Wood and Based on Stephen Selfs information in Wood, C.A., and Kienle, J., (1990).

Kienle, 1990: See: http://www.bendnet.com/users/jensen/volcano/newmex/jemez.html.

Woodward Woodward, L. A., "Tectonic Framework of Albuquerque Country," in Albuquerque 1982: Country II, Guidebook - 33rd New Mexico Geological Society, Field Conference (1982). 


\section{ACTS and STATUTES}

American Indian Religious Freedom Act (AIRFA) of 1978, as amended.

Archaeological Resources Protection Act (ARPA) of 1979, as amended.

Atomic Energy Act of 1954, as amended.

Clean Air Act (CAA) of 1955, as amended (CAAA). Title 42 U.S.C. 7401.

Clean Water Act (CWA) of 1948, (Federal Water Pollution Control Act), as amended; Title 33 U.S.C. 1251.

Comprehensive Environmental Response, Compensation, and Liability Act (CERCLA) of 1980, as amended. Title 40 U.S.C. 9601.

Cultural Resources Act.

Emergency Planning and Community Right to Know Act (EPCRA) of 1986 (Enacted by Public Law 99-499, October 17, 1986; 42 U.S.C. 11001 et seq.).

Endangered Species Act, (16 U.S.C. $\$ 1531$ et sec.).

Federal Facility Compliance Act (FFCA) of 1992. Public Law 102-386.

Federal Insecticide, Fungicide, and Rodenticide Act (FIFRA), as amended. Title 7 U.S.C. 136.

Hazardous and Solid Waste Amendments Act of 1984, Module IV to RCRA Section 3004u.

National Environmental Policy Act (NEPA) of 1969, as amended. Title 42 U.S.C. 4321 et seq.

National Emission Standards for Hazardous Air Pollutants (NESHAP).

National Historic Preservation Act of 1966, as amended, Section 106, Advisory Council on Historic Preservation Comment on Federal Undertakings (16 U.S.C. 470f).

Pollution Prevention Act of 1990 (42 USC 13102).

Resource Conservation and Recovery Act (RCRA) of 1976. Public Law 94-580, 1976, 90 Statute 2795.

(RCRA Section 3004j Land Disposal Restrictions)

(RCRA Section 6002 Federal Procurement)

(RCRA Subpart S Action Levels)

Superfund Amendments and Reauthorization Act (SARA) of 1986. Title III, Section 313, "Toxic Chemical Release Reporting."

Safe Drinking Water Act (SDWA).

Toxic Substances Control Act (TSCA) of 1976. U.S.C. \$2601 et seq.

Water Quality Act of 1987. Public Law 100-4, 1987, 100 Statute 7. 


\section{CODE OF FEDERAL REGULATIONS}

10 CFR 20

10 CFR 834

10 CFR 1021

40 CFR 50

40 CFR 51

40 CFR 52

40 CFR 58

40 CFR 60

40 CFR 61

40 CFR 63

40 CFR 64

40 CFR 70

40 CFR 71

40 CFR 72-78

40 CFR 80

40 CFR 82

40 CFR 85-86

40 CFR 93

40 CFR 112

40 CFR 122

40 CFR 123

40 CFR 124
Standards for Protection Against Radiation (Radiation levels in water).

Radiation Protection of the Public and the Environment, draft.

National Environmental Policy Act Implementing Procedures (General Revisions for DOE).

National Primary and Secondary Ambient Air Quality Standards (changed several times since 1971).

Guidelines for Onsite Meteorological Measurements.

Approval and Promulgation of Implementation Plans (Air Quality).

Ambient Air Quality Surveillance (changed several times since 7/1/94).

Standards of Performance for New Stationery Sources.

National Emission Standard for Hazardous Air Pollutants (NESHAP). (Subpart M pertains to Asbestos and Subpart $\mathrm{H}$ pertains to Radionuclides, "National Emission Standards for Emissions of Radionuclides Other Than Radon From Department of Energy Facilities," as amended. (changed many times since 1973 and 1985).

National Emission Standard for Hazardous Air Pollutants for Source Categories, 40 CFR 63, Subpart T, National Emission Standard for Halogenated Solvent Cleaning.

Administration Enforcement and Inspection.

State Operating Permit Programs (changed since 1993).

Operating permit.

Acid Rain.

Regulation of Fuels and Fuel Additives.

Protection of Stratospheric Ozone.

Oxygenated fuels.

Determining Conformity of Federal Actions to State or Federal Implementation Plans.

Oil Pollution Prevention (changed several times since 1973).

EPA Administered Permit Programs: The National Pollutant Discharge Elimination System (NPDES) (changed several times since 1980).

State Program Requirements, (NPDES) (changed several times since 1980).

Procedures for Decision Making, (NPDES) (changed several times since 1980). 


\section{CODE OF FEDERAL REGULATIONS}

40 CFR 125

40 CFR 136

40 CFR 141

40 CFR 143.3

40 CFR 260-282

40 CFR 260

40 CFR 261

40 CFR 262

40 CFR 263

40 CFR 264

40 CFR 265

40 CFR 266

40 CFR 268

40 CFR 270

40 CFR 271

40 CFR 272

40 CFR 279

40 CFR 280

40 CFR 281

40 CFR 302

40 CFR 355

40 CFR 370

40 CFR 372

40 CFR 761

40 CFR 763
Criteria and Standards for the National Pollutant Discharge Elimination System (NPDES), (changed several times since 1979).

Guidelines Establishing Test Procedures for the Analysis of Pollutants, as amended August 15, 1990.

National Primary Drinking Water Regulations, as amended. January 15, 1992, (changed many times since 1992).

Secondary Maximum Contaminant Levels.

(RCRA Regulations).

Hazardous Waste Management System: General.

Identification and Listing of Hazardous Waste, (changed many times since 1982).

Standards Applicable to Generators of Hazardous Waste.

Standards Applicable to Transporters of Hazardous Waste.

Standards for Owners and Operators of Hazardous Waste Treatment, Storage, and Disposal Facilities, including Subpart F, "Releases for Solid Waste Management Units," Section 264.101 - "Corrective Action for Solid Waste Management Units," (changed since 1994).

Interim Status Standards for Owners and Operators of Hazardous Waste Treatment, Storage, and Disposal Facilities, (changed since 1991).

Standards for the Management of Specific Hazardous Wastes and Specific Types of Hazardous Waste Management Facilities.

Land Disposal Restrictions, (changed since 1991).

EPA Administered Permit Programs: The Hazardous Waste Permit Program.

Requirements for Authorization of State Hazardous Waste Programs.

Approved State Hazardous Waste Management Programs.

Standards for the Management of Used Oil.

Technical Standards and Corrective Action Requirements for Owners and Operators of Underground Storage Tanks, (changed many times since 1991).

Approval of State Underground Storage Tank Programs.

Designation, Reportable Quantities, and Notification (CERCLA Implementing).

Emergency Planning and Notification (EPCRA).

Hazardous Chemical Reporting: Community Right-to-Know (EPCRA).

Toxic Chemical Release Reporting: Community Right-to-Know.

Polychlorinated Biphenyls (PCBs) Manufacturing, Processing, Distribution in Commerce, and Use Prohibitions.

Asbestos. 


\section{CODE OF FEDERAL REGULATIONS (Concluded)}

40 CFR 1500 Chapter V, Council on Environmental Quality (NEPA Implementing Regulations)

through 1508 (changed since 1978).

49 CFR 106-199

Chapter 1, Subtitle B, Department of Transportation Regulations, Research and Special Programs Administration (Hazardous and Radioactive Waste Shipments). 


\section{DOE ORDERS}

DOE 1997c: U.S. Department of Energy, Occurrence Reporting and Processing of Operations Information, DOE Order 232.1a. U.S. Department of Energy, Washington, DC (August 1, 1997).

DOE 1997d: U.S. Department of Energy, National Environmental Policy Act Compliance Program, DOE Order 451.1a. U.S. Department of Energy, Washington, DC (June 5, 1997).

DOE 1996d: U.S. Department of Energy, Comprehensive Emergency Management, DOE Order 151.1. U.S. Department of Energy, Washington, DC (Change 2, August 21, 1996).

DOE 1993a: U.S. Department of Energy, Radiation Protection of the Public and the Environment, DOE Order 5400.5. U.S. Department of Energy, Washington, DC (February 8, 1990, change 2, January 7, 1993).

DOE 1991a: U.S. Department of Energy, Planning and Preparedness for Operational Emergencies, DOE Order 5500.3A. U.S. Department of Energy, Washington, DC (1991, change 1, February 27, 1992).

DOE 1991b: U.S. Department of Energy, Quality Assurance, DOE Order 5700.6C. U.S. Department of Energy, Washington, DC (August 21, 1991).

DOE 1990a: $\quad$ U.S. Department of Energy, General Environmental Protection Program, DOE Order 5400.1. U.S. Department of Energy, Washington, DC (1988, change 1, June 21, 1990).

DOE 1988a: U.S. Department of Energy, Radioactive Waste Management, DOE Order 5820.2A. U.S. Department of Energy, Washington, DC (September 26, 1988). 


\section{EXECUTIVE ORDERS}

EO 11988: $\quad$ Floodplain Management (Signed May 24, 1977; 42 FR 26951, 3 CFR, 1977 Comp., p. 117; Amended by Executive Order 12148, July 20, 1979; 44 FR 43239, 3 CFR, 1979 Comp., p. 412).

EO 11990: Protection of Wetlands (Signed May 24, 1977; 42 FR 26961, 3 CFR, 1977 Comp., p. 121).

EO 12843: $\quad$ Procurement Requirements and Policies for Federal Agencies for Ozone Depleting Substances.

EO 12856: $\quad$ Federal Agency Compliance With Right-to-Know Laws and Pollution Prevention Requirements (Signed August 3, 1993; 58 FR 41981, August 6, 1993).

EO 12873: $\quad$ Federal Acquisition, Recycling and Waste Prevention. (Signed October 20, 1993; 58 FR 54911 , October 22, 1993; amended 6y EO 12995, March 25, 1996; 61 FR 13645, March 28, 1996).

EO 12902: Energy Efficiency and Water Conservation at Federal Facilities. (Signed March 8, 1994). 


\section{NEW MEXICO REGULATIONS}

20 NMAC 4.1

20 NMAC 5

20 NMAC 6.2

20 NMAC 7.1

20 NMAC 9.1

20 NMAC 11.01

20 NMAC 11.02

20 NMAC 11.03

20 NMAC 11.04

20 NMAC 11.05

20 NMAC 11.06

20 NMAC 11.07

20 NMAC 11.20

20 NMAC 11.21

20 NMAC 11.22

20 NMAC 11.23

20 NMAC 11.40

20 NMAC 11.41

20 NMAC 11.42

20 NMAC 11.43

20 NMAC 11.44

20 NMAC 11.60

20 NMAC 11.61

20 NMAC 11.62

20 NMAC 11.63

20 NMAC 11.64
(FFCAct implemented) incorporates by reference 40 CFR 260-270.

Underground Storage Tanks (USTs).

New Mexico Water Quality Control Commission (NMWQCC) regulations.

Drinking Water.

(Biohazardous waste).

National Primary and Secondary Ambient Air Quality Standards.

Permit Fees.

Conformity (State and Federal Plans).

Ambient Air Quality Surveillance.

Visible Air Contaminants.

Emergency Action Plan.

Variance Procedure.

Airborne Particulate Matter.

Open Burning (regulated burns).

Wood Burning.

Stratospheric Ozone Protection.

Source Registration.

Authority-to-Construct.

Operating Permit (application under review).

Stack Height Requirements.

Emissions Trading.

Permitting in Nonattainment Areas.

Prevention of Significant Deteriorization.

Acid Rain.

New Source Performance Standards.

NESHAP Subpart $C, H$, and $M$. 
NEW MEXICO REGULATIONS (Concluded)

20 NMAC 11.65 Volatile Organic Compounds.

20 NMAC 11.66 Process Equipment.

20 NMAC 11.67 Equipment, Emissions and Limitations.

20 NMAC 11.68 Incinerators.

20 NMAC 11.69 Patological Waste Destructors.

20 NMAC $11.90 \quad$ Administration, Enforcement, Inspection.

20 NMAC 11.100 Motor Vehicle Inspection-Decentralized and Centralized.

through 11.101

20 NMAC 11.102

through 11.103

Oxygenated Fuels Motor Vehicle Visible Emissions. 


\section{Glossary}

Atomic Energy Act (AEA) of 1946 - The AEA established the Atomic Energy Commission (AEC). The AEC replaced the Manhattan Project on December 31, 1946. During the first half of 1946, Congress debated whether atomic energy should be under civilian or military control-civilian control won. The AEA placed further development of nuclear technology under civilian rather than military control. Senator McMahon, the author of the AEA, (also known as the McMahon Act), called it "a radical piece of legislation" because it gave the AEC a monopoly over both military and commercial uses of atomic energy. The AEA specified that atomic energy should be directed "toward improving public welfare, increasing the standard of living, strengthening free competition among private enterprises ... and cementing world peace." However, the AEA prohibited private companies or individuals from owning nuclear materials and patenting inventions related to atomic energy. The AEA also restricted information on using nuclear materials to produce energy, as well as on designing, making, and using atomic weapons.

Asbestos - A fibrous mineral used in construction materials because of its fire-retardant and heatresistant properties. Asbestos particles have the potential to pose significant health risks if inhaled. Asbestos materials are contained in insulation (e.g., above ceilings and around pipes and tanks), ovens, floor tiles, and various laboratory equipment. SNL/NM's policy on asbestos abatement is dependent on whether the asbestos material is uncontained and, therefore, inhaleable. All uncontained friable asbestos in structures and equipment is removed for disposal. If the asbestos-contaminated portion cannot be practically disposed, it may be necessary for the entire piece of equipment or construction component to be removed for disposal.

Clean Air Act (CAA) - The objectives of the CAA are to protect and enhance the quality of the nation's air and, thereby, protect public health and the environment. Federal clean air legislation, first enacted in 1955, and modified in 1963, was completely rewritten as the Clean Air Act (CAA) of 1970. Major revisions and additions to the CAA were made by the Clean Air Act Amendments (CAAA) of 1977; the CAA was further and significantly amended in 1990.

Comprehensive Environmental Response, Compensation, and Liability Act (CERCLA) of 1980 CERCLA as amended, defines certain assessment activities and reporting requirements for inactive waste sites for all federal facilities.

Environmental Restoration (ER) process - The ER process describes the remedial action of an ER site. It begins with the identification of potentially contaminated sites (based on past operational activities) followed by a preliminary assessment and inspection. Many sites will be determined to need No Further Action (NFA) due to the absence of contamination or the presence of very small amounts not exceeding regulatory action levels. Once a site has been identified as requiring remediation, it will undergo a comprehensive site characterization, followed by an analysis of cleanup alternatives, a selection of the best alternative, and ultimately, remedial action. 
Nonradioactive waste categories - are defined as:

- Chemical Waste - any disposed item containing chemicals, certain metals, or chemicallycontaminated materials.

- RCRA-Hazardous Waste - a chemical waste regulated under 40 CFR 261.3

- Toxic Substance Control Act (TSCA) Waste - a substance contaminated with TSCAregulated chemicals (e.g., polychlorinated biphenyls (PCBs) and asbestos)

- Industrial Solid Waste - waste from manufacturing process that is not regulated under RCRA

- Municipal Waste - domestic/household trash

- Solid Waste - office related non-hazardous waste (as it applies to SNL/NM)

National Environmental Policy Act (NEPA) of 1969 - NEPA, as amended, is the basic national charter for protection of the environment, which applies to all federal facilities. NEPA establishes policy, sets goals, and provides the means for carrying out the policy. Essentially, these requirements can be summarized by the twin NEPA objectives as it applies to DOE: (1) consider the environmental impacts of actions proposed by SNL/NM, and (2) provide opportunities for public review of these impacts before decisions to precede are made with proposed projects/actions.

National Pollutant Discharge Elimination System (NPDES) - is contained in amendments to the Federal Clean Water Act of 1987 (40 CFR 122). Affected sites, as outlined in the amendment, must obtain an NPDES permit for storm water runoff to any municipal storm drain system and/or storm water discharge from industrial sites that enter significant bodies of water (e.g., lakes, rivers, and oceans). The criteria set by the Environmental Protection Agency (EPA) that mandates storm water runoff permitting includes all facilities that have been classified under a set of Standard Industrial Classification (SIC) codes for particular industrial activities (codes 20 through 39).

Operable Units (OUs) - OUs are the potential Environmental Restoration (ER) release sites identified in the Installation Assessment report and subsequent evaluations that are grouped together within geographic and event-related boundaries for budget development and project tracking purposes. Section 3004(u) of the Resource Conservation and Recovery Act (RCRA), "Continuing Releases at Permitted Facilities," requires investigation of all past and present Solid Waste Management Units (SWMUs), which includes any facility that has collected, stored, processed, and/or disposed of refuse, sludge, garbage, or other discarded materials, and hâs a potential for release of hazardous waste or hazardous constituents.

\section{Radioactive Waste Categories -}

- High-Level Waste (HLW) - typically contains highly radioactive short-lived fission products as well as other long-lived isotopes. Most HLW comes from reactor operations, which produce spent fuel. However, spent fuel from SNL's reactors are not categorized as waste since the fuel is reprocessed.

- Transuranic (TRU) Waste - without regard for source or form, waste that is contaminated with alpha-emitting transuranium radionuclides with half-lives greater than 20 years and concentrations greater than 100 curies per gram (Ci/g) at the time of assay. In some cases, it may be determined that other alpha contaminated wastes, particular to a specific site, must be managed as TRU waste.

- Mixed Waste $(M W)$ - waste that contains both Resource Conservation and Recovery Act (RCRA)-regulated hazardous constituents and radioactive materials. 
- Low-Level Waste (LLW) - comprises most all other radioactive wastes that are not classified under the above three categories. Most LLW contains small amounts of radioactivity within a large volume of material.

Reportable Quantity (RQ) - A threshold amount of certain listed chemicals that have been inadvertently released to the environment. Chemical inventory and release information is required by the Comprehensive Environmental Response, Compensation, and Liability Act (CERCLA) - also known as Superfund-and the Superfund Amendments and Reauthorization Act (SARA) Title III. CERCLA requires that any release to the environment in any 24-hour period of any pollutant or hazardous substance in a quantity greater than or equal to the RQ, be reported immediately to the National Response Center (NRC). However, if the release is "federally permitted" under CERCLA, Section 101(10)(H), it is exempted from CERCLA reporting. This reporting exemption also applies to any federally permitted release under SARA, Title III.

Resource Conservation and Recovery Act (RCRA) - RCRA was signed into law on October 21, 1976, as amendments to the Solid Waste Disposal Act(SWDA) of 1965. Further amendments made to RCRA in 1984, entitled the Hazardous and Solid Waste Amendments (HSWA), provide a set of criteria for Land Disposal Restrictions (LDRs) of hazardous waste. These provisions were fully implemented on May 8, 1980, making it unlawful to dispose untreated waste to the ground (except in a case-by-case determination for a "No Migration Variance" made by the Environmental Protection Agency [EPA]). All hazardous waste must meet strict treatment standards to reduce the toxicity, volume, and/or likelihood of migration from a disposal site before it can be disposed of to land. The RCRA regulatory framework is a "cradle to grave" process that requires detailed reporting for all aspects of hazardous waste handling. Facilities that generate, treat, store, or dispose of hazardous waste must obtain a RCRA operating permit from the EPA or designated state authority. Hazardous waste generators who store waste onsite for more than 90 days must obtain a treatment, storage, and disposal facility RCRA Operating Permit. As part of the permit process, RCRA also requires owners to show a documented waste minimization program, which will reduce the volume and/or quantity and toxicity of their waste. Under the Part B Operating Permit at SNL/NM, RCRA regulated waste can be stored up to a maximum of 1 year before it must be shipped offsite to a permitted treatment storage and disposal facility (TSDF).

Safe Drinking Water Act (SDWA) - The SDWA has set National Primary Drinking Water Standards designed to protect human health by regulating the discharge of nontoxic and toxic pollutants into both groundwater and surface water sources from residential, municipal, and industrial discharges. The goal of the SDWA is to preserve the quality of the nation's water supply. Individual states have been delegated responsibility by the Environmental Protection Agency (EPA) for developing programs and procedures necessary to ensure that the quality of the water supply meets EPA standards. States set standards for the maximum allowable concentrations of pollutants and requirements for monitoring and reporting. Individual states can elect to accept primacy of the regulations only if the state's regulations are stricter than the Federal standards. Since New Mexico's regulations are not stricter than those set by the EPA, the Federal standards apply.

Superfund Amendments and Reauthorization Act (SARA) of 1986 - SARA amended Comprehensive Environmental Response, Compensation, and Liability Act (CERCLA), the Solid Waste Disposal Act (SWDA), and the Internal Revenue Code, as well as providing some free-standing provisions. Among the free-standing provisions is SARA Title III, also known as the 
"Emergency Planning and Community Right-to-Know Act of 1986" (EPCRA). EPCRA applies to all facilities in which there is present a threshold amount of extremely dangerous substances equal to or greater than the threshold planning quantity, or in specifically designated amounts as determined by the local community.

Toxic Substances Control Act (TSCA) of 1976 - TSCA, as amended and administered by the Environmental Protection Agency (EPA), specifies requirements for the manufacture, distribution, use, handling, and disposal of specific toxic chemicals and materials including polychlorinaed biphenyls (PCBs) and asbestos. The main focus of this legislation, however, is on the production and manufacturing aspects of toxic chemicals before they become waste. It also requires testing and regulation of all new chemical substances, as well as regulation of some currently existing substances known or suspected to have harmful health and environmental effects. At SNL/NM, compliance with TSCA primarily involves regulation of PCBs and asbestos as well as the import and export of specifically listed chemicals. In the event of waste containing both a TSCA substance and a Resource Conservation and Recovery Act (RCRA) regulated hazardous substance, the stricter regulation will apply.

Underground Storage Tank (UST) - As defined by the New Mexico regulations, a UST is any tank or combination of tanks and associated piping that are used to contain regulated substances, and which has a tank/piping volume that is 10 percent or more beneath the surface of the ground. The State of New Mexico regulations are based on both the age of the UST as well as the depth to groundwater. 


\section{APPENDIX A}

\section{ENVIRONMENTAL REGULATIONS AND STANDARDS}


(This page is intentionally blank.) 


\section{Contents}

INTRODUCTION

A-4

\section{TABLES}

A-1 Derived Concentration Guides (DCGs) for Selected Radionuclides .

A-2 Radiation Standards for Protection of the Public in the Vicinity of

U.S. Department of Energy Facilities ...................................................................................... A-6

A-3 Groundwater Monitoring Parameters Required by 40 CFR 265, Subpart F .............................. A-7

A-4 U.S. Environmental Protection Agency Interim Primary Drinking-Water Supply Parameters ........ A-8

REFERENCES 


\section{INTRODUCTION}

Radiation protection standards for the public have been established by the U.S. Department of Energy (DOE) to protect public health. This is accomplished by limiting radiation doses (resulting from DOE operations) received by individuals residing in uncontrolled areas. These standards are based on the risk to members of the public. Environmental monitoring requirements for DOE operations are established in DOE Order 5400.1, General Environmental Protection Program (DOE 1990a). Radiation protection standards are provided in DOE Order 5400.5, General Radiation Protection of the Public and the Environment (DOE 1993a).

\section{DOE Orders}

DOE Order 5400.5 limits the annual effective dose equivalent (EDE) to any member of the public to 100 millirem per year (mrem/yr). This annual EDE should be estimated based on all DOE emission sources and all exposure pathways. DOE Order 5400.5 also contains the Derived Concentration Guide (DCG) for concentrations of radionuclides in water and air that could be continuously consumed or inhaled (365 days/year). EDE doses must not exceed the DOE primary radiation protection standard of $100 \mathrm{mrem} / \mathrm{yr}$. Table A-1 contains the DCGs pertinent to activities at Sandia National Laboratories/New Mexico (SNL/NM) and to this report.

\section{NESHAP}

DOE facilities are also required to comply with U.S. Environmental Protection Agency (EPA) standards for radiation protection. On December 15, 1989, the EPA issued its final rule on National Emission Standards for Hazardous Air Pollutants (NESHAP) for radionuclides. This rule mandates that air emissions from DOE facilities shall not cause any individual of the public to receive in any year an EDE of greater than $10 \mathrm{mrem} /$ year from air pathways. Table A-2 summarizes the public radiation protection standards that are applicable to DOE facilities. In addition to these quantitative standards, the overriding DOE policy is that exposures to the public shall be maintained as low as reasonably achievable (ALARA).

\section{RCRA}

Table A-3 lists the 40 CFR 265, Subpart F, parameters required for groundwater monitoring analysis, implemented under the Resource Conservation and Recovery Act (RCRA). Table A-4 shows the EPA interim primary drinking water standards (40 CFR 265, Appendix III) for the groundwater monitoring parameters. At SNL/NM, this regulation applies to Environmental Restoration (ER) sites. 
TABLE A-1. Derived Concentration Guides (DCGs) for Selected Radionuclides*.

\begin{tabular}{|c|c|c|c|c|}
\hline \multirow[b]{2}{*}{ Nuclide } & \multicolumn{2}{|c|}{ Ingested Water } & \multicolumn{2}{|c|}{ Inhaled Air ${ }^{\dagger}$} \\
\hline & $\underset{(\mu \mathrm{Ci} / \mathrm{ml})}{\mathrm{DCG}}$ & $\begin{array}{c}\mathbf{f}_{1} \\
\text { Value }^{\star \star *}\end{array}$ & $\mathrm{DCG}(\mu \mathrm{Ci} / \mathrm{ml})$ & $\begin{array}{c}\text { Solubility } \\
\text { Class }\end{array}$ \\
\hline Tritium (water) & $2 \times 10^{-3}$ & -- & $1 \times 10^{-7}$ & W \\
\hline Cesium-137 & $3 \times 10^{-6}$ & 1 & $4 \times 10^{-10}$ & $\mathrm{D}$ \\
\hline Uranium, total $\left(U_{100}\right) \S$ & $5 \times 10^{-6}$ & -- & $1 \times 10^{-13}$ & $\mathrm{Y}$ \\
\hline
\end{tabular}

NOTE: $\quad \mu \mathrm{Ci} / \mathrm{ml}=$ microcuries per milliliter *DOE Order 5400.5, Chapter III (DOE 1993a).

tDCG for tritium in air is adjusted for skin absorption. ** $\mathrm{F}_{1}$ value is the gastrointestinal absorption factor.

${ }^{\S} \mathrm{A}$ conversion from microcuries per milliliter $(\mu \mathrm{Ci} / \mathrm{ml})$ to micrograms per liter $(\mu \mathrm{g} / \mathrm{l})$ may be made using:

$$
u g / l=X u C i / m l \frac{\left[1.49 \times 10^{9} u g / l\right]}{[1 u C i / m l]}
$$


TABLE A-2. Radiation Standards for Protection of the Public in the Vicinity of U.S. Department of Energy Facilities

\section{General Dose Limits}

All Pathways *

The effective dose equivalent (EDE) for any member of the public from all routine DOE operations ${ }^{\dagger}$ (natural background and medical exposures excluded) shall not exceed the values given below:

Effective Dose Equivalent (EDE) $\underline{\mathrm{mrem} / \mathrm{yr}} \underline{\mathrm{mSv} / \mathrm{yr}}$

Primary limit 100 1

NOTE: $\quad$ *DOE Order 5400.5, Chapters I and II (DOE 1993a).

${ }^{\dagger}$ Routine DOE operations means normal planned activities, including remedial actions and naturally occurring radionuclides released by DOE processes and operations.

** 40 CFR 61, Subpart H for radionuclides, National Emission Standards for Hazardous Air Pollutants (NESHAP). 
TABLE A-3. Groundwater Monitoring Parameters Required by 40 CFR 265, Subpart $F^{\star}$

\begin{tabular}{lll}
\hline $\begin{array}{l}\text { Contamination } \\
\text { Indicator }\end{array}$ & $\begin{array}{c}\text { Groundwater } \\
\text { Quality }\end{array}$ & $\begin{array}{c}\text { Appendix III } \\
\text { Drinking Water Supply }\end{array}$ \\
\hline & Chloride & Arsenic \\
pH & Iron & Barium \\
Specific Conductivity & Manganese & Cadmium \\
Total Organic Halogen (TOX) & Phenol & Chromium \\
Total Organic Carbon (TOC) & Sodium & Fluoride \\
& Sulfate & Lead \\
& & Mercury \\
& & Nitrate (as N) \\
& & Selenium \\
& & Silver \\
& & Endrin \\
& & Lindane \\
& & Methoxychlor \\
& Toxaphene \\
& & $2,4-D$ \\
& & $2,4,5-T P$ Silvex \\
& Radium \\
& & Gross Alpha \\
& Gross Beta \\
& Coliform Bacteria \\
& Turbidity
\end{tabular}

NOTE: *Resource Conservation and Recovery Act (RCRA).

${ }^{\dagger} 40$ CFR 265, Appendix III. 
TABLE A-4. U.S. Environmental Protection Agency Interim Primary Drinking-Water Supply Parameters

Parameter

Arsenic $†$

Barium $\uparrow$

Cadmium $\dagger$

Chromium $\dagger$

Lead $\dagger$

Mercury ${ }^{\dagger}$

Selenium $\dagger$

Silver ${ }^{\dagger}$

Fluoride

Nitrate

Total Coliform

Turbidity

Radium-226

Radium-228

Gross Alpha

Gross Beta

Endrin

Lindane

Methoxychlor

Toxaphene

2,4-D

2,4,5-TP Silvex
Standard ${ }^{*}$

Units

0.05

$\mathrm{mg} / \mathrm{l}$

1.0

$\mathrm{mg} / \mathrm{l}$

0.01

$\mathrm{mg} / \mathrm{l}$

0.05

$\mathrm{mg} / \mathrm{l}$

0.05

$\mathrm{mg} / \mathrm{l}$

0.002

$\mathrm{mg} / \mathrm{l}$

0.01

$\mathrm{mg} / \mathrm{l}$

0.05

$\mathrm{mg} / \mathrm{l}$

1.4-2.4

$\mathrm{mg} / \mathrm{l}$

10

$\mathrm{mg} / \mathrm{l}$

$1 / 100 \mathrm{ml}$

$\mathrm{cl} / 100 \mathrm{ml}$

$1 \mathrm{TU}$

NTU

$5 \mathrm{pCi} / 1$

$\mathrm{pCi} / 1$

$5 \mathrm{pCi} / 1$

pCi/l

$15 \mathrm{pCi} / 1$

pCi/l

$4 \mathrm{mR} / \mathrm{yr}$

$\mathrm{mR} / \mathrm{yr}$

0.0002

$\mathrm{mg} / \mathrm{l}$

0.004

$\mathrm{mg} / \mathrm{l}$

0.1

$\mathrm{mg} / \mathrm{l}$

0.005

$\mathrm{mg} / \mathrm{l}$

0.1

$\mathrm{mg} / \mathrm{l}$

0.01

NOTE: $\mathrm{mg} / \mathrm{l}=$ milligrams per liter; $\mathrm{ml}=$ milliliters; $\mathrm{NTU}=$ nephelometric turbidity unit; $\mathrm{pCi} / \mathrm{l}=$ picocuries per liter; $\mathrm{mR} / \mathrm{yr}=$ milliroentgens per year.

${ }^{*} 40$ CFR 265, Appendix III.

${ }^{\dagger}$ Total metals (unfiltered sample). 


\section{REFERENCES}

DOE 1990a: U.S. Department of Energy, General Environmental Protection Program, DOE Order 5400.1. DOE, Washington, DC (1988; change 1, June 21, 1990).

DOE 1993a: U.S. Department of Energy, Chapter I, General Radiological Protection of the Public and the Environment; Chapter II, Requirements for Radiation Protection of the Public and the Environment; and Chapter III, Derived Concentration Guides for Air and Water. DOE Order 5400.5. DOE, Washington, DC (February 8, 1990, change 2, January 7, 1993).

EPA 1976: $\quad$ U.S. Environmental Protection Agency, U.S. EPA National Interim Primary Drinking Water Regulations, EPA-570/9-76-003. EPA, Washington, DC (1976).

Resource Conservation and Recovery Act (RCRA) of 1976. Public Law 94-580, 1976, 90 Statute 2795.

40 CFR 61, Subpart H for radionuclides. National Emission Standards for Hazardous Air Pollutants (NESHAP).

40 CFR 141, 1975. National Primary Drinking Water Regulations, as amended January 15, 1992.

40 CFR 265, 1980. Interim Status Standards for Owners and Operators of Hazardous Waste Treatment, Storage, and Disposal Facilities, as amended December 23, 1991. 
(This page is intentionally blank.) 


\title{
APPENDIX B
}

\author{
SITE ENVIRONMENTAL REPORT \\ FOR THE \\ KAUAI TEST FACILITY (KTF) \\ OPERATED BY SANDIA NATIONAL LABORATORIES
}




\section{ACKNOWLEDGEMENTS}

The 1997 report for the Kauai Test Facility (KTF) was compiled with contributions from Joan Harris, Alonzo Lopez, Hans Odewage, Heidi Herrera, Adrian Jones, John Copland, and Dick Hay. Dianne Duncan and Rebecca Sanchez provided editing and word processing. 


\section{CONTENTS}

\section{ABBREVIATIONS}

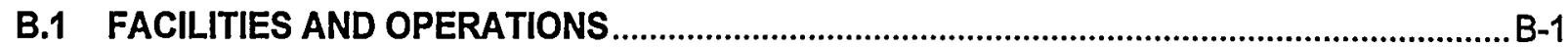

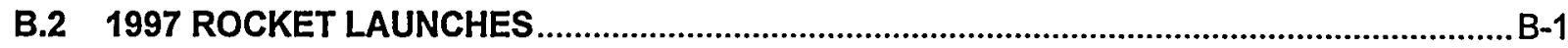

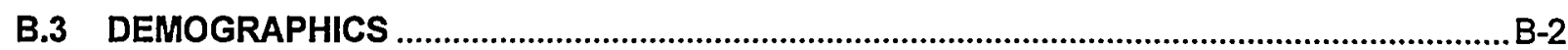

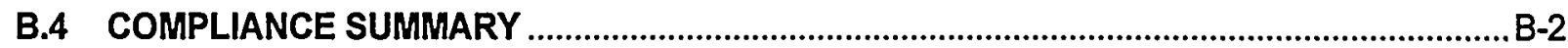

Comprehensive Environmental Response, Compensation, and Liability Act (CERCLA) ...........B-2

Superfund Amendments and Reauthorization Act (SARA) .........................................................

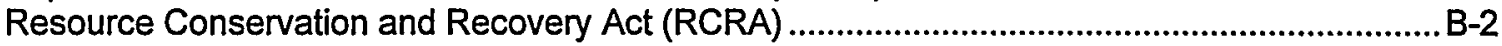

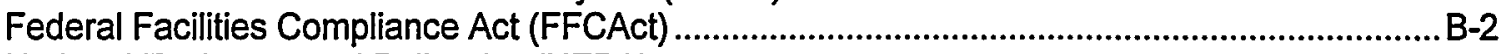

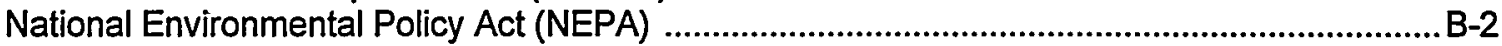

Clean Air Act (CAA) and Clean Air Act Amendments (CAAA) of 1990 ..........................................

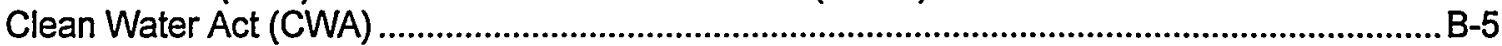

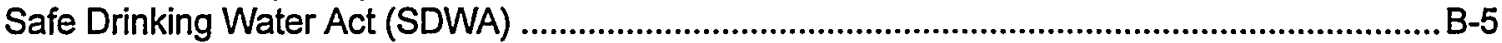

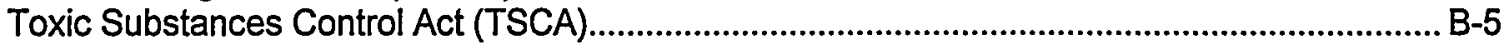

Federal Insecticide, Fungicide, and Rodenticide Act (FIFRA) ................................................

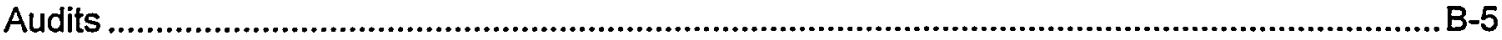

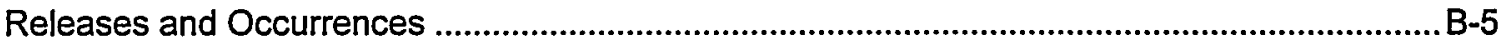

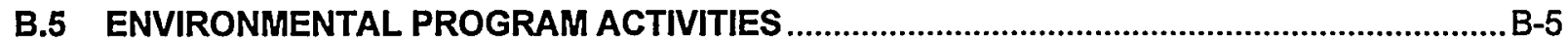

National Environmental Policy Act (NEPA) Program Activities ................................................. B-5

Environmental Restoration (ER) Project Activities ...................................................................

Spill Prevention Control and Countermeasures Plan (SPCC) ..................................................

B.6 ENVIRONMENTAL SURVEILLANCE AND MONITORING ACTIVITIES ............................... B-6

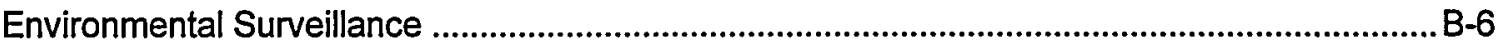

Summary of 1994 Soil Sampling Results and Additional 1995 Analyses ...................................

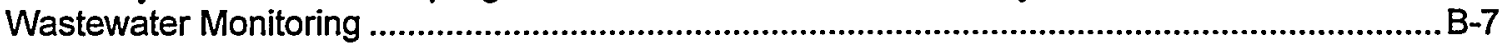

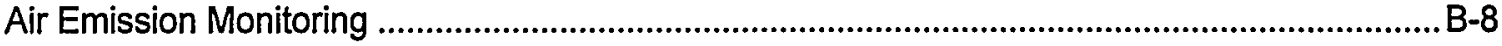

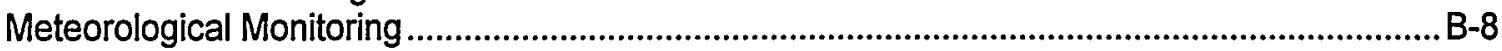

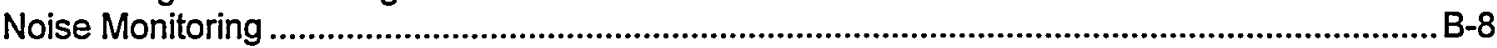

REFERENCES 
FIGURE

B-1 Map of the Pacific Missile Range Facility (PMRF) and the Adjacent Area

B-4

\section{TABLE}

B-1 Permits in Place at KTF

B-3 


\section{ABBREVIATIONS}

\section{Acronyms and Abbreviations}

\begin{tabular}{|c|c|}
\hline $\begin{array}{l}\text { AIRF } \\
\text { ARPA }\end{array}$ & $\begin{array}{l}\text { American Indian Religious Freedoms Act } \\
\text { Archeological Resources Protection Act }\end{array}$ \\
\hline BMDO & Ballistic Missile Defense Organization \\
\hline CERCLA & Comprehensive Environmental Response, Compensation, and Liability Act \\
\hline CWA & Clean Water Act \\
\hline DoD & U.S. Department of Defense \\
\hline DOE & U.S. Department of Energy \\
\hline DOE/AL & U.S. Department of Energy, Albuquerque Operations Office \\
\hline DOE/KAO & U.S. Department of Energy, Kirtland Area Office \\
\hline EA & Environmental Assessment \\
\hline EIS & Environmental Impact Statement \\
\hline EO & Executive Orders \\
\hline EPA & U.S. Environmental Protection Agency \\
\hline EPCRA & Emergency Planning and Community Right-to-Know Act \\
\hline ER & Environmental Restoration \\
\hline ES\&H & Environment, Safety, and Health \\
\hline ESA & Endangered Species Act \\
\hline FIFRA & Federal Insecticide, Fungicide, and Rodenticide Act \\
\hline FFCAct & Federal Facilities Compliance Act \\
\hline FONSI & finding of no significant impact \\
\hline FTU & Flight Test Unit \\
\hline HCRR & Hawaiian Code of Rules and Regulations \\
\hline IT & International Technology (Corp.) \\
\hline KTF & Kauai Test Facility \\
\hline MW & mixed waste \\
\hline NEPA & National Environmental Policy Act \\
\hline NESHAP & National Emission Standards for Hazardous Air Pollutants \\
\hline NFA & No Further Action \\
\hline NHPA & National Historic Preservation Act \\
\hline NPDES & National Pollutant Discharge Elimination System \\
\hline NPL & National Priorities List \\
\hline NSPS & New Source Performance Standards \\
\hline PCB & polychlorinated biphenyl \\
\hline PMRF & Pacific Missile Range Facility \\
\hline PSD & Prevention of Significant Deterioration \\
\hline PTO & Permit-to-Operate \\
\hline RCRA & Resource Conservation and Recovery Act \\
\hline SARA & Superfund Amendments and Reauthorization Act \\
\hline SDI & Strategic Defense Initiative \\
\hline SDWA & Safe Drinking Water Act \\
\hline SNL & Sandia National Laboratories \\
\hline SNL/NM & Sandia National Laboratories/New Mexico \\
\hline SPCC & Spill Prevention Control and Countermeasures (Plan) \\
\hline STARS & Strategic Targeting System \\
\hline TSCA & Toxic Substances Control Act \\
\hline US & rage tank \\
\hline
\end{tabular}




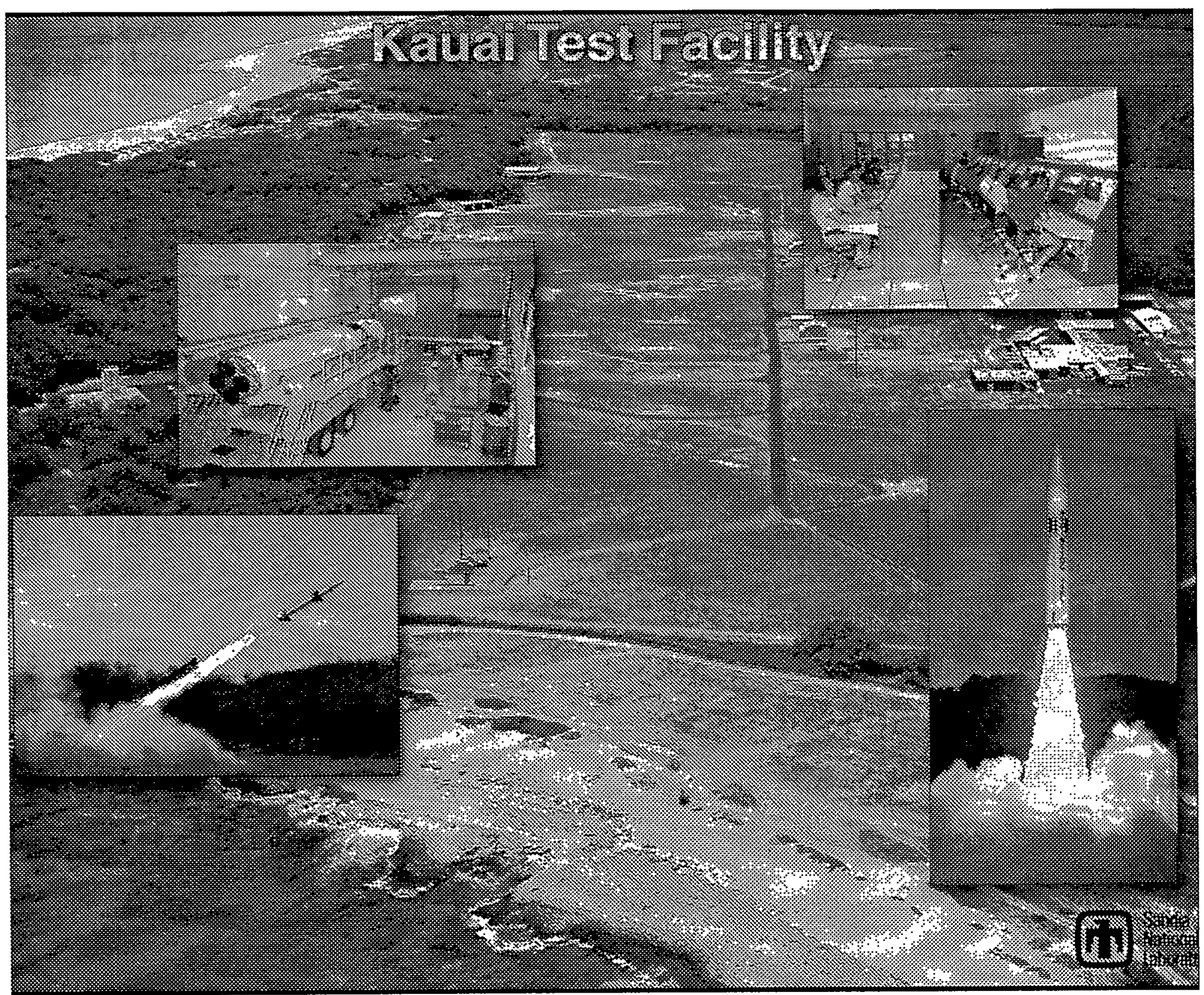


Oandia National Laboratories (SNL) operates the Kauai Test Facility (KTF) as a rocket preparation, launching, and tracking facility for the U.S. Department of Energy (DOE), as well as in support of other U.S. military agencies. The KTF exists as a facility within the boundaries of the U.S. Department of Defense (DoD) Pacific Missile Range Facility (PMRF). KTF is located on the island of Kauai at the north end of the PMRF, near Nohili Point (Figure B-1). This site environmental report for the KTF has been prepared as required by DOE Order 5400.1, General Environmental Protection Program (DOE 1990a).

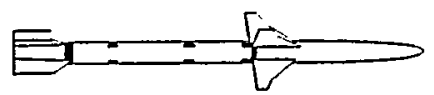

\section{B.1 FACILITIES AND OPERATIONS}

KTF has been an active rocket-launching facility since 1962. SNL's Kauai Test Facility and Range Interfaces Department manages and conducts the rocket-launching activities at KTF. The site is primarily used for testing rocket systems with scientific and technological payloads, advanced development of maneuvering re-entry vehicles, scientific studies of atmospheric and exoatmospheric phenomena, and Strategic Defense Initiative (SDI) programs. Nuclear devices have never been launched from KTF nor have radiological materials been used at KTF.

The first facilities at KTF were constructed in the early 1960s to support the National Readiness Program. The most recent construction, completed in 1994, added four buildings to support DOE and SDI launches. From 1992 to 1997, there have been 10 launches.

The KTF launcher field was originally designed to accommodate 40 launch pads, but only 15 pads were constructed. Of these, 11 have had their launchers removed. Beyond the implementation of portions of the original plan, two additional launch pads were constructed:
Pad 41 at Kokole Point, and Pad 42, the Strategic Targeting System (STARS) launch pad. The launcher field site has a number of permanent facilities used to support rocket operations. In addition to rocket launch pad sites, KTF facilities include missile assembly areas, data acquisition and operations facilities, a maintenance shop, and a trailer compound for administration and technical support personnel. Other features at KTF include extensive radar tracking and world-wide radio communication access to other DoD facilities.

The administrative area of $\mathrm{KTF}$, known as the Main Compound, is located in a fenced area near the North Nohili access road from PMRF. Within the fenced compound, a number of trailers and vans are interconnected with a network of concrete docks and covered walkways. The majority of these temporary facilities are used during operational periods to support the field staff at KTF. During nonoperational periods, general maintenance continues and dehumidifiers remain in operation (to protect equipment). Additionally, there are a number of permanent buildings, most of which are in use year-round to support and maintain KTF facilities (Helgesen 1990).

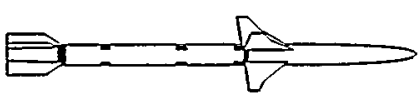

\section{B.2 1997 ROCKET LAUNCHES}

Although there were no rocket launches from the KTF in 1997, preparations were made for a project called "Red Crow." The Red Crow launch was approved by DOE on December 9, 1997 , and was originally expected to launch by January or February 1998. The launch has been delayed until late May 1998. SNL will conduct this launch as part of the Ballistic Missile Defense Office (BMDO) Program to characterize the performance of missile countermeasures and to collect data to aid countermeasures development.

The Red Crow Program will involve launching a two stage TALOS/CASTOR I sounding rocket that will carry a payload to the exoatmosphere. 
The first stage consists of a Hercules TALOS MK1 1 Mod 2 rocket motor; the second stage is a Thiokol XM-33 CASTOR I rocket. The payload will carry a suite of three experiments.

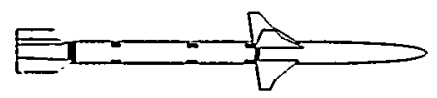

\section{B.3 DEMOGRAPHICS}

KTF employs 13 permanent onsite personnelthree are employed by SNL and 10 are SNL contractors. During operational periods, when rocket launches occur, an additional 50 to 130 persons from the U.S. mainland are employed at KTF (DOE 1992). The closest population center is the town of Kekaha (population 3,300), which is 8 miles from KTF.

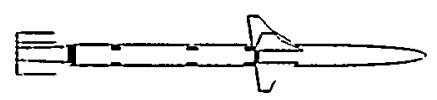

\section{B.4 COMPLIANCE SUMMARY}

The following list of statutes provide an overview of compliance status of SNL's operations at KTF in 1997. Table B-1 lists the applicable permits in place at KTF.

Comprehensive Environmental Response, Compensation, and Liability Act (CERCLA) CERCLA, also known as Superfund, addresses areas of past spills and releases. In 1995, a site inspection was performed at KTF to determine compliance with CERCLA requirements. On September 30, 1996, the U.S. Environmental Protection Agency (EPA) sent DOE, Albuquerque Operations Office (DOE/AL) a letter regarding the results of the Site Inspection with a determination of No Further Action (NFA). This confirmed that KTF met all CERCLA requirements and that the site did not warrant being on the National Priorities List (NPL), a list of high priority cleanup sites. A site inspection report (SNL 1995a) was the basis upon which EPA determined the NFA. EPA designated ongoing oversight of KTF to the Hawaii Department of Health Hazard Evaluation and Emergency Response Office. KTF did not require any additional sampling or remediation at the three Environmental Restoration (ER) sites present. The EPA did recommend continued reevaluation for environmental contamination due to the launching facility present. Exhaust and explosions continue to be the main source of metals and other hazardous releases.

\section{Superfund Amendments and Reauthorization Act (SARA)}

SARA Title III requires chemical inventory information and threshold quantity reporting as directed by the Emergency Planning and Community Right-to-Know Act (EPCRA), Sections 311 and 312. All required information has been submitted to the State of Hawaii.

\section{Resource Conservation and Recovery Act (RCRA)}

In 1994, KTF reached "small quantity hazardous waste generator" status as defined by RCRA, and therefore, obtained an EPA Identification Number. However, the volume of waste generated in 1997 qualified the KTF to maintain "conditionally exempt small quantity generator" status.

Federal Facilities Compliance Act (FFCAct) The FFCAct addresses the disposition of mixed waste (MW) at federal facilities. No radioactive waste of any kind has been generated or stored at KTF and, therefore, this statute is not applicable to the site.

\section{National Environmental Policy Act (NEPA)}

NEPA requires that all federal facilities address environmental and cultural impacts in appropriately detailed documentation before initiating projects. Acts and Executive Orders (EOs) directly related to NEPA compliance include the following:

- Endangered Species Act (ESA)

- Cultural Resources Act

- National Historic Preservation Act (NHPA) 
- Archeological Resources Protection Act (ARPA)

- American Indian Religious Freedoms Act (AIRF)

- Executive Order 11990, Protection of Wetlands

- Executive Order 11988, Floodplain Management

The DOE, Kirtland Area Office (DOE/KAO) oversees NEPA compliance at KTF. In accordance with NEPA, a comprehensive sitewide Environmental Assessment (EA) was completed for KTF in 1992 (DOE 1992). A Finding of No Significant Impact (FONSI) was issued on July 17, 1992. This is the current NEPA document that covers all rocketlaunching activities at the site. Additionally, a specific Environmental Impact Statement (EIS) for the STARS program is in place for rocket launching of this type (DoD 1992).

In 1997, Sandia supported the PMRF in the development of their programmatic Pacific Missle Range Facility Enhanced Capability
Environmental Impact Statement (EIS) (DoD 1998).

Clean Air Act (CAA) and Clean Air Act Amendments (CAAA) of 1990

Ambient air quality is regulated by Hawaii's Code of Rules and Regulations (HCRR), Title 11, Chapter 59 (11-59-4) under the jurisdiction of the Hawaii Department of Health, Air Pollution Control Department. Currently, there are no facilities at KTF that require air permits or compliance with the New Source Performance Standards (NSPS), "Prevention of Significant Deterioration (PSD)," or 40 CFR 161, "National Emission Standards for Hazardous Air Pollutants" (NESHAP). Within the boundaries of PMRF no federal air emission permits are held either by DOE for KTF, or by DoD for PMRF. However, the two electrical generators at $\mathrm{KTF}$ are permitted for operation by the State of Hawaii under "Permit-to-Operate" (PTO) (SNL 1996a).

According to EPA requirements, the 1997 Annual Emissions Report Form was submitted to the State of Hawaii on February 18, 1998. KTF was in compliance with all air quality regulations in 1997.

Table B-1. Permits in Place at KTF

\begin{tabular}{|l|l|l|l|l|}
\hline Type & Permit Number & $\begin{array}{l}\text { Date } \\
\text { Issued }\end{array}$ & $\begin{array}{l}\text { Expiration } \\
\text { Date }\end{array}$ & Regulatory Agency \\
\hline $\begin{array}{l}\text { Resource Conservation } \\
\text { and Recovery Act } \\
\text { (RCRA) }\end{array}$ & HI0000363309 & Sep. 23, 1994 & Not specified - & $\begin{array}{l}\text { EPA Region IX } \\
\text { and Hawaii Dept. of } \\
\text { Health }\end{array}$ \\
\hline $\begin{array}{l}\text { Diesel Generators } \\
\text { (air emission) }\end{array}$ & $\begin{array}{l}\text { PTO } \\
\text { No. P-737-1591 }\end{array}$ & Oct. 25, 1993 & Oct. 1, 1998* & State of Hawaii \\
\hline
\end{tabular}

NOTE: $\mathrm{PTO}=$ Permit to Operate.

*A change in state law after this permit was issued will likely require a new permit application at renewal time (as opposed to an extension). 


\section{Pacific Ocean}

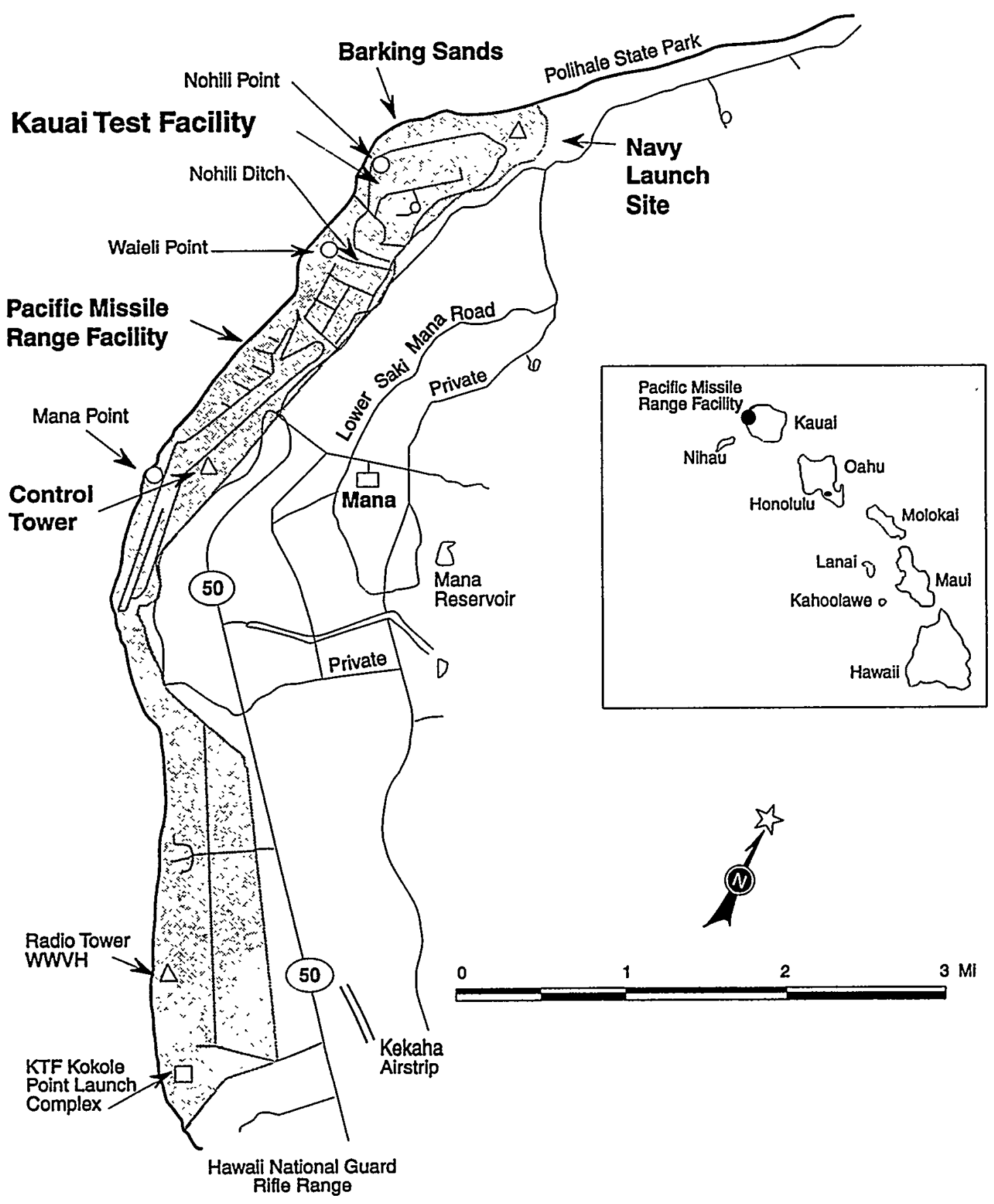

FIGURE B-1. Map of the Pacific Missile Range Facility (PMRF) and the Adjacent Area The Kauai Test Facility (KTF) is to the north, near Nohili Point. 


\section{Clean Water Act (CWA)}

There were no compliance issues with respect to any state or federal water pollution regulations in 1997. The KTF facility has three septic tanks onsite, which currently do not require permits from the State of Hawaii.

A National Pollutant Discharge Elimination System (NPDES) permit is not required due to the lack of significant storm water runoff or wastewater discharging beyond the site boundary into "waters of the U.S," as defined in the regulation. However, this is not to say that there is no runoff. The EPA has expressed some concern with storm water runoff washing off the launcher pads and discharging to the ocean. Some of the downstream pathways include habitat for several federally designated endangered or threatened species. The EPA has therefore requested that environmental sampling be performed at these areas in the future.

Underground Storage Tank (UST) - On May 4, 1997, the State of Hawaii conducted an inspection of the UST located at KTF. A September 29, 1997, letter to SNL documented several deficiencies noted during the inspection. SNL corrected the problems and a verification of compliance status was submitted to the State of Hawaii on October 10, 1997.

\section{Safe Drinking Water Act (SDWA)}

The SDWA does not apply directly to SNL activities at KTF because all drinking water is obtained through PMRF's facilities.

\section{Toxic Substances Control Act (TSCA)}

TSCA regulates the distribution of polychlorinated biphenyls (PCBs) and asbestos. The transformers on the KTF site have been tested and are free of PCBs, and there are no asbestos issues at the site.

\section{Federal Insecticide, Fungicide, and}

Rodenticide Act (FIFRA)

FIFRA controls the distribution and application of pesiticides. Pesticide use at KTF follows all EPA requirements.

\section{Audits}

On May 4, 1997, the State of Hawaii inspected the one UST in place at the KTF. Corrective actions were required and completed.

\section{Releases and Occurrences}

There were no releases or other environmental occurrences at KTF in 1997.

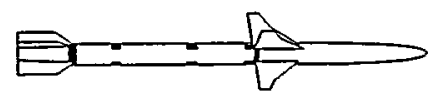

\section{B.5 ENVIRONMENTAL PROGRAM ACTIVITIES}

This section describes three environmental programs: the National Environmental Policy Act (NEPA) Program, the Environmental Restoration (ER) Project, and the Spill Prevention Program.

\section{National Environmental Policy Act (NEPA) Program Activities}

In completing the KTF EA in 1992, several environmental baseline surveys were conducted and are summarized below:

- Green Sea Turtle Survey Report - This survey found at least 32 green sea turtles (Chelonia mydas agassizi) in five locations at KTF. The study concluded that constructing an additional launch pad and conducting further launches, similar to those conducted at KTF since 1962; most likely will not have any quantifiable negative effects on green sea turtles inhabiting waters near KTF (IT 1990a).

- Botanical Survey Report - This survey identified four major vegetation types at KTF and recommended that vehicles be kept off the beaches and dunes. The report recommended moving the entire Ophioglossum concinnum colony (a Category $1^{\mathrm{a}}$ proposed endangered fern) to a compatible area within PMRF because of

\footnotetext{
a Category 1 is a species for which biologic vulnerability exists to the point of support of proposal to list as endangered or threatened.
} 
the colony's proximity to a beach access road and its location in a frequently-mowed kiawe/koahaole vegetation zone (IT 1990b).

- Ornithological and Mammal Survey Report - This survey determined relative population densities of bird species and identified mammalian species at KTF. Based on mitigations implemented and other commitments made in the KTF EA, no adverse impacts are expected for birds or mammals as a result of KTF operations (IT 1990c).

- Soil Sampling Report - Sampling was undertaken to delineate the extent and concentration of lead, aluminum, and beryllium in the soil at KTF and to determine whether the concentrations pose a risk to human health or the environment. The soil sampling results were used to estimate the potential for future soil contamination or human exposure from use of KTF as a launch facility (IT 1990d).

- Archaeological Survey and Sampling No significant cultural resources were found at the surface level on KTF, during this study. However, subsurface testing at one area indicated a potential for buried cultural resource materials (Gonzalez and Berryman 1990).

\section{Environmental Restoration (ER) Project Activities}

In 1996, the three ER sites present at KTF were closed out. All ER sign posting designations were removed from these areas:

- $\quad$ Photo Lake Discharge (ER Site 132)

- Drum Rack Area (ER Site 133)

- Launcher Field (ER Site 163)

The EPA made the determination of NFA on September 30, 1996 in response to the site inspection report generated in 1994 and submitted to the EPA in May 1995 (SNL 1995a) No additional assessment or sampling is required at KTF relative to these ER sites. This, however, does not preclude that other environmental sampling activities will take place at KTF.

Spill Prevention Control and Countermeasures Plan (SPCC)

SNL cooperates with the Navy's Spill Prevention Control and Countermeasures (SPCC) Plan, Pacific Missile Range Facility (U.S. Navy 1991), which is applicable to the 10,000-gallon above-ground fuel tank inside the Main Compound. KTF has only one UST in its inventory as previously discussed.

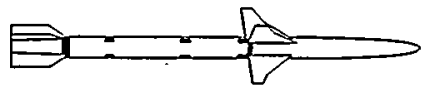

\section{B.6 ENVIRONMENTAL SURVEILLANCE AND MONITORING ACTIVITIES}

This section summarizes effluent monitoring and terrestrial surveillance activities conducted at KTF.

\section{Environmental Surveillance}

Terrestrial surveillance monitoring of soils and surface water was not conducted in 1997. Currently, environmental sampling is conducted on a periodic and "as needed" basis due to the limited activities at KTF. Past sampling results, last performed in 1994, indicate that any contamination present is minimal and is not migrating.

When sampling does occur, environmental monitoring and surveillance is conducted in accordance with the KTF environmental monitoring plan (SNL 1996b). Because of the high permeability of the dune sands on which KTF is sited, there is no perennial surface water and few established drainages onsite; therefore, water and sediment samples have not been collected during past sampling events. However, as previously noted, the EPA has expressed some concern regarding runoff to the ocean from the launch pad area. Future 
sampling will likely include sediments from these drainage areas.

Routine groundwater sampling is not performed because the groundwater is unacceptable for consumption or irrigation of any kind (DOE 1992). KTF is located only slightly above sea level, and the water table consists of brackish non-potable water floating on seawater. However, when groundwater was sampled at several previous ER sites in 1994 using temporary wells, no contamination was detected. Future sampling will be dependent on resource availability and demonstrated need.

\section{Summary of 1994 Soil Sampling Results and Additional 1995 Analyses}

In July 1994, SNL Environmental Surveillance staff from SNL, New Mexico (SNL/NM) collected 32 soil samples within a six-mile radius of the site -19 from onsite and perimeter locations and 11 from offsite locations. The specific objective of the 1994 sampling was to provide limited baseline data for the radiological and nonradiological (toxic metal) concentrations of the soil in and around KTF. Results of the 1994 sampling activity and further data analysis performed the following year were published in the appendix of the 1995 SNL/NM Site Environmental Report, Albuquerque, New Mexico (SNL 1996c).

Radiological results showed no statistical difference between onsite and offsite samples, supporting the historical process knowledge that no radioactive contaminants have been dispersed at the site.

Site-wide nonradiological results showed elevated concentrations for the following metals:

$\begin{array}{ll}\text { Barium } & \text { Chromium } \\ \text { Cobalt } & \text { Copper } \\ \text { Iron } & \text { Lead } \\ \text { Magnesium } & \text { Nickel } \\ \text { Silicon } & \text { Strontium } \\ \text { Zinc } & \end{array}$

However, many of the elevated metals were only marginally above offsite locations. Only iron, magnesium, silicon, zinc, and nickel showed significantly higher results as compared to offsite data. Original data results are published in the appendix of the 1994 SNL/NM Site Environmental Report, Albuquerque, New Mexico (SNL 1995b).

Further analysis of the nonradiological data was conducted in 1995 to provide a planning basis for future sampling activities (Shyr et al. 1996 and SNL 1996c). Of the metals reported as elevated, iron, magnesium, and silicon were removed from discussion because they naturally occur in high concentrations in the native soil and have a low health impact.

Zinc and lead showed significantly higher concentrations than offsite. The highest value for zinc was 3,100 ppm, however, this was only 10 percent of the proposed RCRA action level $(23,000 \mathrm{ppm})$. Lead concentrations were high at two onsite locations. One location with results of $110 \mathrm{ppm}$ was slightly above the RCRA toxicity level (100 ppm). Because lead is an expected pollutant generated during the launch of some rocket systems, lead contamination was addressed in the KTF EA (DOE 1992). If KTF is decommissioned in the future, samples will be collected to determine if lead present in soils will require remediation.

\section{Wastewater Monitoring}

KTF produces only sanitary sewage, which is directed into five wastewater systems-three septic tanks and two French drains-in accordance with Hawaii Underground Injection Control regulations. The septic systems are periodically pumped by licensed state-certified contractors and inspected by state officials. The limited quantity of sewage released does not impact any protected waters and, as noted earlier, there are no potable water wells in the area of KTF. Currently, septic tanks do not require permitting or sampling. Sampling is performed as a Best Management Practice on an "as needed" basis. The last sampling occurred in June 1993 (IT 1994). 


\section{Air Emission Monitoring}

Based on effluent air monitoring results of the STARS Flight Test Unit 1 (FTU-1) in February 1993 (EPA 1993) and the CDX rocket launch in the summer of 1992 (SNL 1992a), it was determined that rocket launches at KTF were not a significant source of air pollutants-launches are infrequent and emissions recorded did not exceed federal and state standards (DoD 1994). Because the STARS type rocket produces the greatest air emissions and remained within acceptable limits, it can be assumed that future launches of this type will also be within acceptable limits. Therefore, no further air emission monitoring is planned at this time. If a new rocket type is launched from KTF that differs in emission substance from the STARS rocket, or air emission requirements change, funding for future monitoring will be requested.

\section{Meteorological Monitoring}

Onsite meteorological instruments are used during test periods to characterize atmospheric transport, diffusion conditions, and stability classes. Due to the infrequency of launches, no formal meteorological monitoring plan is in place for KTF. Climatic information representative of KTF can be obtained from the PMRF.

\section{Noise Monitoring}

In accordance with the Quiet Communities Act of 1978 (42 U.S.C. 4901 et seq.), noise monitoring was conducted in February 1993 during the STARS FTU-1 launch to confirm the determination made in the STARS EIS that noise produced from the largest launch would be below maximum acceptable levels (SNL 1993). Data collected in the nearest town of Kekaha indicated that levels were no louder than noise generated from passing vehicles on a nearby highway. No further noise monitoring is planned at this time.

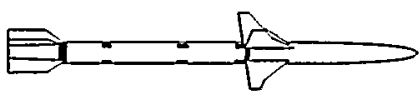




\section{REFERENCES}

DoD 1998: $\quad$ U.S. Department of Defense, Pacific Missile Range Facility Enhanced Capability Environmental Impact Statement (EIS), (Draft). U.S. Department of Defense, Department of the Navy, Kauai, HA, (April, 1998).

DoD 1994: $\quad$ U.S. Department of Defense, Ambient Air Quality Assessment No. 43-21-N3DD-94, Strategic Target System, Operational and Deployment Experiments Simulator Missile Launch, Pacific Missile Range Facility, Kauai Test Facility, Barking Sands, Kauai, Hawaii, 6-25 July 1994. U.S. Army Environmental Hygiene Agency, Department of Defense (1994).

DoD 1992: $\quad$ U.S. Department of Defense, Final Environmental Impact Statement for the Strategic Target System, Volumes I through III. U.S. Army Strategic Defense Command, Department of Defense (May 1992).

DOE 1990a: $\quad$ U.S. Department of Energy, General Environmental Protection Program, DOE Order 5400.1. DOE, Washington, DC (1988, change 1, June 21, 1990).

DOE 1992: U.S. Department of Energy, Kauai Test Facility Environmental Assessment, DOE/EA-0492. U.S. Department of Energy, Albuquerque Operations Office (DOE/AL), Albuquerque, NM (1992).

EPA 1993: Environmental Protection Agency, "Memorandum, USAEHA, MCHB-ME-AQ: Ambient Air Quality Assessment No. 43-21-N204-93, Strategic Target System Missile Launch, Pacific Missile Range Facility, Kauai Test Facility, Barking Sands, Kauai, Hawaii February 19-March 1, 1993." U.S. Environmental Protection Agency, Washington, DC (June 9, 1993).

Gonzalez and T. Gonzalez, and J. Berryman, Archaeological Survey and Testing, Department of Berryman Energy, Kauai Test Facility. Prepared for Sandia National Laboratories, Albuquerque, 1990: $\quad$ NM (1990).

Helgesen 1990: R. F. Helgesen, Safety Assessment for the Kauai Test Facility at Barking Sands, Kauai, SAND892548. Sandia National Laboratories, Albuquerque, NM (1990).

IT 1990a: IT Corporation, A Survey of the Green Sea Turtle Population Fronting the Kauai Test Facility, Pacific Missile Range, Barking Sands, Kauai: An Analysis of Potential Impacts with Implementation of the Strategic Defense Initiative. IT Corporation, prepared for Sandia National Laboratories, Albuquerque, NM (1990).

IT 1990b: IT Corporation, Botanical Survey of the Kauai Test Facility Site, Barking Sands, Kauai, Hawaii. IT Corporation, prepared for Sandia National Laboratories, Albuquerque, NM (1990).

IT 1990c: IT Corporation, Ornithological Survey Report of the Kauai Test Facility Site, Barking Sands, Kauai, Hawaii. IT Corporation, prepared for Sandia National Laboratories, Albuquerque, NM (1990).

IT 1990d: $\quad$ IT Corporation, Soil Sampling Program for Sandia National Laboratories, Kauai Test Facility, Kauai, Hawaii. IT Corporation, prepared for Sandia National Laboratories, Albuquerque, NM (1990).

IT 1994: $\quad$ IT Corporation, Sandia National Laboratories/New Mexico Septic Tank Monitoring Report, Kauai Test Facility. IT Corporation, prepared for Sandia National Laboratories, Albuquerque, NM (June 1994). 
SNL 1996a: Sandia National Laboratories, "State of Hawaii Permit to Operate (PTO) No. P 738-1591," Memo from Mike du Mond to Su Hwang, Sandia National Laboratories, Albuquerque, NM (February 1, 1996).

SNL 1996b: Sandia National Laboratories, Environmental Monitoring Plan (EMP), Sandia National Laboratories, Kauai Test Facility. Sandia National Laboratories, Albuquerque, NM (October 21, 1996).

SNL 1996c: $\quad$ Sandia National Laboratories, 1995 SNL/NM Site Environmental Report, Albuquerque, New Mexico, SAND96-2270. Sandia National Laboratories, Albuquerque, NM (September, 1996).

SNL 1995a: Sandia National Laboratories, Site Inspection Report for the Kauai Test Facility. Sandia National Laboratories, Albuquerque, NM (April 1995).

SNL 1995b: Sandia National Laboratories, 1994 SNL/NM Site Environmental Report, Albuquerque, New Mexico, SAND95-1953. Sandia National Laboratories, Albuquerque, NM (1995).

SNL 1993: "SNL Acoustic Monitoring Plan of the STARS Flight Test Unit 1." Memo to Linda Ninh from B. E. Swanson. Sandia National Laboratories, Albuquerque, NM (1993).

SNL 1992a: Sandia National Laboratories, "CDX Rocket Motor Effluent Monitoring," Memo from W. E. Stocum (7712) to R. G. Hay (2723). Sandia National Laboratories, Albuquerque, NM (1992).

Shyr et aI. $\quad$ L. J. Shyr, R. Haaker, and H. Herrera, 1995 Terrestrial Surveillance Data Analysis Report for the 1996: SNL/NM and KTF Sites, SAND98-0612. Sandia National Laboratories, Albuquerque, NM (1996).

U.S. Navy U.S. Navy, Spill Prevention Control and Countermeasure Plan, Pacific Missile Range Facility. 1991: Pacific Division, Naval Facilities Engineering Command, Pearl Harbor, HI (February 1991). 


\section{REGULATIONS AND EXECUTIVE ORDERS}

- Comprehensive Environmental Response, Compensation, and Liability Act (CERCLA) of 1980, as amended. Title 40 U.S.C. 9601.

- Superfund Amendments and Reauthorization Act (SARA) of 1986. Title III, Section 313, "Toxic Chemical Release Reporting."

- Clean Air Act (CAA) of 1955, as amended. Title 42 U.S.C. 7401.

- Clean Air Act Amendments (CAAA) of 1990.

- Clean Water Act (CWA) of 1948, (Federal Water Pollution Control Act), as amended. Title 33 U.S.C. 1251.

- Federal Insecticide, Fungicide, and Rodenticide Act (FIFRA), as amended. Title 7 U.S.C. 136.

- National Environmental Policy Act (NEPA) of 1969, as amended. Title 42 U.S.C. 4321.

- Resource Conservation and Recovery Act (RCRA) of 1976. Public Law 94-580, 1976, 90 Statute 2795.

- Toxic Substances Control Act (TSCA) of 1976. U.S.C. $\$ 2601$ et seq.

- Quiet Communities Act of 1978, Public Law 95-609, 92 stat. 3079, U.S.C. 4901 et seq. November 9, 1978

- HCRR, Title II, Chapter 59, Hawaii Code of Rules and Regulations for Air Quality.

- Executive Order (EO) 11988, Floodplain Management (Signed May 24, 1977; 42 FR 26951, 3 CFR, 1977 Comp., p. 117; Amended by Executive Order 12148, July 20, 1979; 44 FR 43239, 3 CFR, 1979 Comp., p. 412).

- Executive Order (EO) 11990, Protection of Wetlands (Signed May 24, 1977; 42 FR 26961, 3 CFR, 1977 Comp., p. 121). 
(This page is intentionally blank.) 